\title{
"Acquire and Beget a Temperance": The Virtue of Temperance in The Faerie Queene Book II and Hamlet
}

By

\section{Gillian Chell Hubbard}

\begin{abstract}
A thesis
submitted to the Victoria University of Wellington in fulfilment of the requirements for the degree of

Doctor of Philosophy

in English Literature
\end{abstract}

Victoria University of Wellington

2010 


\begin{abstract}
Shakespeare's Hamlet, like Spenser's The Faerie Queene Book II, is a work systematically concerned with the virtue of temperance. This conclusion is reached partly from comparison between Spenser and Shakespeare. But I also set their works in the context of a range of relevant sources available to the Early Modern period. While comparisons between aspects of $F Q I I$ and Hamlet are not unknown, critical attention to their common foundation in temperance has been limited.

Like Spenser in FQII, Shakespeare in Hamlet is concerned with a virtue that has its roots in the interconnected Greek precepts "Know Thyself", "Nothing in Excess" and "Think Mortal Thoughts." To be sophron (temperate) is to live in accordance with these precepts. Spenser presents the opposed vice of intemperance through the excesses of avarice and lust in the Cave of Mammon and the Bower of Bliss. Shakespeare portrays a court in Elsinore where excess, irascibility, lust and avarice for power are barely concealed beneath a veneer of Ciceronian social decorum and a didactic commitment to self-control. Comparison with the varied aspects of temperance in FQII makes clear how constantly and variously Hamlet reflects upon temperance and intemperance.
\end{abstract}

There is an underlying tension in both FQII and Hamlet between traditional ideals of moderation and self-control on the one hand, and imagery and archetypes of the Fall and tainted human nature on the other. This tension arises naturally in a treatment of a virtue which, although it derives from classical thought, was carefully assimilated into Christian theology by the Church Fathers. As in much Early Modern writing, we find strands of Platonic, Aristotelian and Stoic thought that privilege reason (on the one hand) intermingled with (on the other) an Augustinian emphasis on the heart, the will, and dependence on Christian grace.

In Hamlet Shakespeare portrays Claudius as one intractably intemperate in the Aristotelian sense, a condition made apparent in his inability to repent. Claudius' apparent rational self-control is based on premises that are ultimately false; his actions therefore derive from "false prudence" as defined by Aquinas. His projection of reasonableness forces his antagonist, Hamlet, into a range of irascible and irrational behaviour, some of which is calculated and some of which is not.

Both Spenser and Shakespeare present an anatomy of the processes of rational self-control and their disruption by the passions. Both are also concerned with the metaphysical dimensions of temperance, both Platonic and Pauline. When 
Hamlet (like a Greek sophronistes) sees it as his duty to act against Claudius, "this canker of our nature," he is expressing a confused mixture of desires--for ethical and spiritual transformation, political reformation, justice, and an irascible lust for vengeance. It is no coincidence that the problematic endings of both $F Q I I$ and Hamlet echo the conclusion of the Aeneid and its failure to reconcile justice and temperance. 


\section{Acknowledgements}

I have often been aware how extraordinarily lucky I have been in the academic calibre of my supervisors. Without Kathryn Wall's initial rigorous and inspirational teaching of Edmund Spenser, her academic generosity in modelling research approaches and the beacon of her own work, her personal support as a primary supervisor, and much hospitality this study would not have happened. It was invaluable to have Geoff Miles' perspective on the Shakespeare dimensions, and his feedback when Kathryn was on leave. I have appreciated his temperance and his own careful study of virtue ethics in Shakespeare which was always calming to reread.

Marion McLeod is to be thanked for her initial direction; Robert Easting for a lead on Augustine and the fowler; Linda Hardy for the leads on economics; Vincent O'Sullivan for some help with New Testament Greek; Anne Lake Prescott for her affirming suggestions as respondent at Kalamazoo. I have appreciated the academic companionship of other graduate students on level eight of the von Zedlitz building. Thanks to Susan Kaiser for formatting and Peter Morrow for a final editing check.

Finally thanks to my sons Ben and Louis for their belief in me and my husband Anthony, specifically for translation help and for too many other things to enumerate.

Prefatory note:

I was on the point of submission when I encountered Christopher Tilmouth's monograph Passion's Triumph over Reason: A History of the Moral Imagination from Spenser to Rochester. For this reason, I have been unable to engage with this (albeit relevant) work in detail on a continuing basis throughout the thesis. My introductory chapter does, however, take account of Tilmouth's work. 


\section{Table of Contents}

Abstract i

Chapter One: Introduction: "Acquire and beget a temperance" ..............................iii

Chapter Two: Modern and Renaissance temperance: issues of definition 26

Chapter Three: Excess and self-knowledge 48

Chapter Four: Archetypes, revenge and original sin. .68

Chapter Five: Suicide and the unfortified heart 97

Chapter Six: Means, Decorum and Mediocrity. 114

Chapter Seven: 'Towering passion,' rational self-control and conflict in the soul 141

Chapter Eight: The journey of the soul: temperance, assimilation to God and justice . 172

Chapter Nine: Hamlet and the journey towards temperance 208

Works Cited 228 


\section{Chapter One: \\ Introduction: "Acquire and beget a temperance"}

In Act 3 Scene 2 of Hamlet Hamlet famously advises the players to moderate the histrionic nature of their acting, to "use all gently; for in the very torrent, tempest, and, as I may say, whirlwind of your passion, you must acquire and beget a temperance that may give it smoothness" (3.2.4-7). They should not "o'erstep...the modesty of nature" (3.2.16), because "anything so o'erdone is from the purpose of playing" (3.2.17). After both the players and Rosencrantz and Guildenstern have been dismissed, Hamlet and Horatio are left alone in the eye of the storm, the calm before the uproar of the "Mousetrap" play. Hamlet chooses this moment to praise Horatio, because "blest are those / Whose blood and judgement are so well commeddled / That they are not a pipe for Fortune's finger / To sound what stop she please. Give me that man / Who is not passion's slave, and I will wear him / In my heart's core, ay in my heart of heart, / As I do thee" (3.2.58-64). As Philip Edwards comments in his notes to the 2003 New Cambridge edition" ${ }^{1}$ of Hamlet: "It is notable that both to the players here and to Horatio at 59-65 Hamlet is much concerned about the temperance, self-control and moderation which is so much wanting in his own behaviour" (Shakespeare 164).

The importance of "temperance, self-control and moderation" to any treatment of human behaviour in the Early Modern period can scarcely be overestimated. The strongest evidence for its importance to middle to late Elizabethan thinking comes in its selection as the announced theme of the whole second book of Edmund Spenser's epic allegorical poem The Faerie Queene. ${ }^{2}$ Spenser's complex and subtle treatment of temperance follows a book concerned with holiness, and Spenser thus positions temperance in relation to the intellectual debate and discord in the period over the relationship between faith and ethical behaviour. The fault line between faith and ethical behaviour will often become a topic of the study to follow.

Temperance, a virtue that as the Latin temperantia derives from the Greek sophrosyne, can be conceptually elusive, because of the long and complex history of its intellectual evolution. An educated late Elizabethan / early Jacobean audience

\footnotetext{
${ }^{1}$ All Hamlet citation is from this edition unless otherwise specified

${ }^{2}$ All references to The Faerie Queene are to A.C. Hamilton's edition
} 
would more naturally associate its varied permutations because of the intellectual practice of compilation, seen both in the kinds of compilations used in grammar schools and in the more philosophically unified processes of compilation which underpinned the great philosophical and theological works that contributed to the discourses of the period (of which Aquinas' Summa Theologiae is the most obvious example).

It is in part our distance from such practices of clustering ideas that prevents us from seeing the elements of Hamlet as parts of an exploration of temperance, as an exploration similar in nature to that of Book II of The Faerie Queene (FQII). All parts of $F Q \mathrm{II}$ draw on elements (elements that may seem in themselves unconnected) previously organised by philosophers or theologians into a category called temperance. All parts of Hamlet, I will argue, can be seen in a similar way. What we have lost is a sense of some of the processes of categorisation that make this so. Using FQII as a focussing lens is one way of allowing the figure of temperance to emerge in the carpet that is Hamlet; or, to put this another way, in understanding why an aspect of $F Q \mathrm{II}$ is concerned with temperance, we come to see why an aspect of Hamlet will be similarly concerned with temperance. My purpose is not to argue direct influence between $F Q I I$ and Hamlet (although such influence cannot be excluded), or to suggest that both treat temperance in the same way or reach the same conclusions about the nature of temperate behaviour, but to highlight a strong similarity of purpose through thematic similarities. Once such similarity is established, it is in the differences in the treatment that much of the interest of the study lies.

To demonstrate a little of the complexity of the topic in advance, let us return to Edwards' footnote. It is easy to make conceptual links between Edwards' three instances: Hamlet's advice to the players, his praise of Horatio, and his own exhibitions of lack of temperance, self-control and moderation on the stage. But we need also to see that very different aspects of temperance are involved in each case. Hamlet has two purposes in asking the players to be more temperate in their delivery, and both are manipulative and designed to foster truth. The first (one that makes us want to see Shakespeare the actor-director speaking directly to his players or mimicking a voice familiar to them) is an appeal from the heart for a dramatic delivery that, by being temperate, will more accurately represent "the truth" of nature. There is a noble moral purpose for this accuracy: it will, in general terms, enable an audience to more closely see similarities to their own and their fellows' moral behaviour in the action of a play. By being more subtly artificial in their acting, the actors will avoid the 
tell-tale signs of the construction of the artificial, thus making their acting closer to the nature they should represent for this artificial purpose of moral edification. Hamlet, at this moment, in the hands of a good actor (and I have Richard Burton's delivery in mind), will demonstrate the oratorical effect himself, a clearly contrived, controlled and at the same time convincingly sincere delivery of exhortation and passion. Hamlet's advice might then be seen in terms of Aristotle's Poetics or a handbook for rhetoric which draws on the classical role of sophrosyne in oratory (such as that of Abraham Fraunce (Fraunce 1588)). It is temperance as balance and modesty, a "middle way" in delivery, that is essentially at issue at this point.

More personally, and so manipulatively and with more moral ambiguity, Hamlet also needs the temperance of the actors to create an occasion of emotional identification and so an uncontrolled response from Claudius. The actors' temperate delivery of extreme passion will uncover the underlying truth of Claudius's own deep but disguised intemperance, and so make Claudius lose emotional self-control. Temperance is to be used as a weapon. On the revelation of this truth - the truth of Claudius's personal intemperance - depends (more nobly) the higher good of Denmark and (less nobly) the justification for a more murky personal revenge. The control of Hamlet's purpose in his speech to the players will bob uncomfortably against Hamlet's uncontrolled excitement and breaches of decorum (as Edwards notes), especially his speeches to Ophelia, at the time of the actual delivery of the play.

Hamlet's speech to Horatio is delivered in the context of this sprung tension of excitement at the potential imminent disclosure of Claudius's guilt and, like the speech to the players, has a very complex tone. It can also be delivered with a strongly measured calm. It praises "a temperance" in Horatio that is to do with the integrity of the self and is often seen in terms of Stoic apatheia, of a failure to be "passion's slave" because of disengagement from the sources of passion. Horatio's co-meddling of blood and judgement has, in Hamlet's view, enabled him to detach himself from the effects of passion, from passion's slavery. Rather than a form of behaviour to be used for effect in a particular context, Horatio's temperance is an inner state of mind and being. Hamlet moves naturally from one variety of temperance to the other, as if their similarities remind him of their differences - in looking for temperance on the part of the actors, he is reminded of the inner temperance he admires in his friend and may desire for himself, an inner temperance that would pre-empt the need to force a reaction of intemperance in Claudius. Insomuch as Stoic detachment leads to wisdom and truth, then, there is a sense in 
which both of the different aspects of temperance introduced at this point in the play can be associated with a desire for a species of truth.

To point out both similarity and difference in these two treatments of temperance is to point in an opening way to the scope and complexity of the resilient conceptual envelope that is temperance. Temperance, not as a constant state of mind but as the need for active self-control, is revealed by Hamlet's own lack of control, his lack of basic good manners (or temperance as Ciceronian decorum) in his speech to Ophelia while watching the "Mousetrap" play (3.2.99-120). This lack of selfcontrol finds some point of measure against Hamlet's view of the "better self", Horatio, whom he would wear in his "heart of heart." The implied comparison between the two friends, that Hamlet recurrently needs self-control and Horatio (in Hamlet's eyes) does not, suggests the Aristotelian distinction between continence and temperance. For Aristotle the continent person lacks the inner integrity of character that makes self-control habitual. We are pointed, then, in the short sequence of preparation for and delivery of the "Mousetrap" play in Hamlet, towards the temperance of the rhetorician, the habitual temperance that is absence of all desire of the Stoics, and the subset of Aristotelian temperance that looks for moderation in all behaviour, continence. The relationship of temperance to selfknowledge - or lack of self-knowledge on Hamlet's part, as Edwards' note implies is the critical matter of the play that lies behind the sequence. Even Hamlet's dismissal of his praise of Horatio's temperance - "something too much of this" (3.2.64) - amounts at once to a witty injunction against excess in emotion and speech, and as such, a both profound and brisk endorsement of temperance in daily life; and at the same time a dismissal of the Stoic disengagement from life, in this particular case court politics, that apatheia requires. Horatio's temperate detachment, while praiseworthy, is not, at this particular moment, for Hamlet.

Further on in his notes, after explaining the technical dramatic meanings of "action" in the lines "Suit the action to the word, the word to the action, with this special observance, that you o'erstep not the modesty of nature", Edwards continues:

As with his advice on temperance, Hamlet finds it easier to order things in the theatre than in his own life. He has the greatest difficulty in acting in accordance with the 'word' he has been given (1.5.110), and in suiting his words to what he has to act (e.g. 2.2.535-40). (165)

The preoccupation with intellectual processes (that has traditionally been seen as a defining characteristic of Hamlet - we need only think of Laurence Olivier's 
lugubrious "Hamlet, the story of a man who could not make up his mind") and the gap between intellectual processes and action, is also a preoccupation of Spenser's Legend of Sir Guyon or of Temperaunce, and as such an essential ingredient in Spenser's broad treatment of the virtue of temperance. Lynette Black, in "Prudence in Book II of The Faerie Queene," is concerned to present the indispensability of prudence to the perfection of temperance, and establishes the relationship of prudence to action. She presents the ability to discern good from evil as an important attribute of prudence. She then discusses deliberation based on Wise Counsel (and I have italicised the phrases that show the relationship to action):

Aquinas writes “...the gift of Counsel corresponds to prudence, as helping and perfecting it." A second concept related to discernment is the idea that virtuous action results from choices based upon Good Counsel. Prudence is the virtue that activates the others because the person perfected in prudence naturally performs actions that are virtuous; furthermore his deliberated choices imply action. The idea that action follows counsel underlies the balance between speed and deliberation which passes into proverb in the Renaissance. In the words of Erasmus' adage festina lente, one combines "the speed of diligence and the slowness of deliberation." The balanced tension between the opposites which characterizes the mean is implicit in this attribute of prudence. (Black 70)

In Spenser's legend of temperance, according to Black's argument, the titular hero has trouble conquering allegorical representatives of intemperance. The models of temperance, such as that of the mean at Medina's house, also demonstrate the insufficiency of temperance, until Guyon encounters the three sages who represent prudence in the turrets of Alma's castle. This encounter, especially an active involvement with memory through reading historical chronicles, leads to a disposition to virtue.

This disposition to virtue is the mark of its perfection because it evidences a natural inclination to virtuous action. Harry Berger uses the concept that "temperance can be perfected into a natural inclination of being" to show a shift in focus in the last five cantos away from an Aristotelian temperance to a Christian temperance. Good Counsel as a gift of the Holy Spirit perfects prudence that activates the other virtues. The last five cantos operate fundamentally according to this paradigm in that prudence makes it possible for temperance to triumph over her enemies... On leaving the House of Alma, Guyon launches the assault on the Bower of Bliss, the source of the wrongful domination of the lower passions. His assault will restore the subordination of the lower orders to the rule of reason, as Arthur has previously done for Guyon personally in defeating Cymochles and Pyrochles. (76)

Hamlet is also deeply concerned with the role of prudence in perfecting temperance, and various failures of virtue in the play can be seen as failures of 
prudence to perfect temperance. The play's preoccupation with the relationship of thought and action, and its treatment of violent emotional outbursts and breakdowns of emotional self-control, as well as its constant advice-giving, can all be accounted for with reference to temperance's relationship with prudence, the relationship seen in FQII.

Hamlet, for example, demonstrates the relationship of counsel to temperate action in his advice to the players. The players are to act more temperately because he counsels them to do so. Temperance in Harry Berger's sense of a "natural inclination of being" is then praised in the character often described as Hamlet's better self, Horatio - one "[w]hose blood and judgement" are "so well commeddled" (3.2.59), and there is a hint that this is due to more than Stoic apatheia. Hamlet can praise temperance on the one hand and advise it on the other. But ironically, as Edwards points out, he has failed to take his own advice to "acquire and beget a temperance" (3.2.6). If we follow Black's argument, that the early parts of FQII show failures of temperance resulting from failures of prudence, a similar set of failures can also be seen in Hamlet. Let us look briefly at two other examples. First, the second scene of the play centres on Claudius's counsel to Hamlet to temper the outward manifestations of his grief for his father. Hamlet's actions are described as both immoderate and imprudent, and in this way modifying immoderate and imprudent behaviour becomes an announced subject of the rest of the play. Hamlet in turn sees his mother and uncle's behaviour as intemperate and imprudent.

In the second, much later but strongly thematically linked example, Hamlet takes on the role of counsellor to Gertrude after the "Mousetrap" play. In a variant of the "acquiring and begetting" of the temperance speech already given to the players, Hamlet argues, in a very Aristotelian way, that practice will make Gertrude's habit of continence, and through this her moral temperance, more natural. Hamlet's delivery of this advice is of course ironically flawed by the preceding irascibility that results in the death of Polonius, an irascibility that has derived in part from Hamlet's own inability to form a resolved counsel for action for revenge against Claudius. The pattern, of advice to act temperately delivered by flawed counsellors, dominates the play, and points to a series of imbalances in the proper relationships of prudence and temperance. 


\section{Methodology}

The initial approach of this study was to read Hamlet more systematically "in the light of" FQII as an announced Elizabethan treatment of temperance, to establish a pattern of similar thematic concerns. Parallels between the two texts were immediately clear; what was not so immediately clear was the relationship of such parallels to temperance. To understand how systematically both Spenser and Shakespeare (in Hamlet) have arranged variations on the theme of temperance required the illumination of Helen North's comprehensive study of temperance: Sophrosyne: Self-Knowledge and Self-Restraint in Greek Literature. I am indebted at all points to North's rich and densely packed study, a study which did not easily render up its treasures, and which I have failed to exhaust as a source. North finishes her study with Augustine's words in De Moribus Ecclesiae: "Let this be said about temperantia, little enough when one thinks of the magnitude of the subject, but perhaps too much in proportion to the size of this book" (379). I find myself, then, in the best possible company in the experience that temperance is a hard virtue to contain adequately. Reading FQII and Hamlet against Helen North made explicit many aspects of temperance that were involved in both the deeply significant and relatively trivial moments not only of FQII, but also of Hamlet. To take a significant example, one that will be explored in depth in the fourth chapter of this study (and one that does not naturally appear in relation to Hamlet unless Hamlet is seen in terms of the virtue of temperance): Hamlet's self-styled role as "scourge and minister" (3.4.176) reflects the role in Greek literature of the sophronistes, the one who, though not necessarily sophron or temperate themselves, brings temperance to others. Spenser's Guyon, in destroying the Bower of Bliss, performs a parallel role. Having initially understood the basis of this aspect of temperance through Helen North, its use by a range of other writers then became more transparent. In the patristic writing of Ambrose, for example, the role of the Greek sophronistes is overtly linked to the role of the Old Testament prophet. As Tudor and Elizabethan clergy cite and echo the Church Fathers, these old associations of ideas resonate for congregations contemporary with Spenser and Shakespeare. When, in the official Easter homily, the Elizabethan congregation is ordered to "kill and offer...up" (Of the Resurrection, Part 2) their varied intemperate tendencies, a specifically Christian theological frame is at issue, but the injunction is also essentially to do with an act of temperance, with the Elizabethan preacher in the role of sophronistes for his congregation, leading the individual sinner to take revenge on their own intemperate behaviour. It became clear, in other words, that any attempt to understand the treatment of temperance in the zeal of Guyon's destruction of the Bower 
of Bliss, and Hamlet's mission to reverse the rottenness in the state of Denmark, would need to draw on deep classical and Christian roots, roots that had in many cases grown together, not to be easily separated.

Working from sources concerning temperance contemporary with Spenser and Shakespeare made clear how naturally the organisation of aspects of virtues into categories lends itself to the striking of the familiar thematic note in Spenser and Shakespeare. I will use the apparently unimportant aspect of dress as an example. $F Q I I$ makes a point of the dress of Guyon and his Palmer (the latter in black, like Hamlet the scholar), and of the neatness of Medina's attire, a mean between wealth and understatement, paralleling Polonius's sartorial advice to Laertes. Excess and disarray of garments represent forms of intemperance in both works. Hamlet's feigned madness is displayed by a disarray of clothing; Medina's neat coiffure and clothes are disarrayed as she is torn between two warring personified extremes; incontinence, personified as Acrasia, is described as "disarayd" (II.xii.77.3) on her bed of roses.

That clothes and the appropriate wearing of clothes should be related to temperance, and naturally find itself as a subsection of a category of virtue associated with temperance, has long historical roots. Sophrosyne was demonstrated in popular Greek culture by modesty in dress, particularly for women. By the time of Cicero, modesty in dress has become part of that specialised aspect of temperance, decorum. Appropriate dress is a topic in the New Testament epistles, reflecting both Hebraic tradition and the merging of Greek and Hebrew thought in the Wisdom books of the Bible. In the early patristic writings of Clement of Alexandria, the link between Scriptural and classical injunctions over cosmetics and dress is overt. By the time of Aquinas, and the systemisation that influences the view of the virtues of the early modern as well as the medieval period, modesty in dress (and the associated lack of cosmetics) has become one of the categories of virtues associated with temperance in the Summa. Not to use cosmetics has, in other words, thus become in an official way an aspect of temperance for the Church. When Hamlet berates Ophelia, "I have heard of your paintings too, well enough. God hath given you one face and you make yourselves another" (3.1.137-8), he is making (consciously or not) a philosophically and theologically orthodox attack on intemperance. That we can work to this point not only from Aquinas, but from Elizabethan compendia of virtues and from $F Q I$, makes it less likely that the note of temperance is being rung unconsciously in Hamlet through its treatment of apparel. 
While it is unnatural for us to make this connection between cosmetics and temperance, on the one hand, or to connect an attack on cosmetics with Hamlet's praise of Horatio on the other, the connection is likely to be much more transparent to an educated audience of the period. It is, I suspect, because we have not so easily made such connections that the full relevance of temperance to Hamlet has been overlooked (although critics have, like Edwards, circled around facets of its importance for a long time). The source of a particular reference to temperance in Elizabethan and Jacobean writing is sometimes explicit or easily established. The source may be Cicero or Seneca, or Aquinas or Augustine, the New Testament, Horace, Virgil and so on. And so it can be completely transparent that the ethical thought of classical, Biblical and scholastic times about temperance is speaking directly to the period. Sometimes the route to a particular compilation of characteristics associated with temperance is much less clear, as paraphrasing and synonyms and vagaries of translation disguise a direct reference to temperance, or the fact that a set of ideas clearly lies inside the conceptual envelope of temperance. The most important example of this phenomenon during this study was when, only after a period of dipping in and out of the text and further immersion in a range of treatments of temperance, it became apparent to me, that the section of Calvin's Institutes which will be looked at in the next chapter was in all essential respects a Protestant treatment of temperance and, as such, important for understanding Spenser's treatment of temperance.

It also quickly became clear that to support the implications of seeing any particular aspect of temperance in Hamlet through recourse to one set of definitions, or to explore the treatment of temperance by a particular school, or in a particular period, would become problematic. Lynette Black's discussion of prudence, the stimulus for the initial examination of temperance in Hamlet, provides a case in point. Black looks at prudence as derived from Aristotle, through Macrobius, Caussin and Aquinas, and in Lodowick Bryskett. Black represents, in other words, logically and cogently, the scholastic view of prudence. From a scholastic perspective, prudence is the central piece in the moral jigsaw puzzle that must be properly arranged before temperance can be perfected. The Stoics and Aquinas see prudence as the central virtue in the hierarchy of the cardinal virtues, with temperance very firmly at the bottom of this hierarchy, limited to control of the desire for pleasure. The problem with seeing temperance in this way, however, is that it does not account for Spenser's naming of his second allegorical book as a legend 
of temperance rather than a legend of prudence, which must be addressed in other ways. Black (80) acknowledges in a footnote that temperance and not prudence is sometimes seen as the mother of the virtues in Spenser's period.

A different approach to temperance involves understanding those strands in Reformation thinking, particularly in Luther, that run strongly counter to an ideal of moral perfection achieved through a perfected reason. The Augustinian theology that influences the Reformation gives a less clear privilege to prudence as the key virtue in the acquisition of virtue, placing temperance at times more centrally. Prudence is naturally a pivotal virtue when wisdom is seen as the path to God, as it is in the intellectualist tradition of Aquinas. But when love, the heart, and the action of the will come to the centre theologically, as they do in the tradition of voluntarism associated with Augustine, then reason on its own becomes less central. Calvin allies himself with the Augustinian emphasis on the heart when he argues in Institutes of Christian Religion: "Doctrine is not an affair of the tongue, but of the life; is not apprehended by the intellect and memory merely, like other branches of learning; but is received only when it possesses the whole soul, and finds its seat and habitation in the inmost recesses of the heart" (Calvin Institutes Vol 2, 4; bk III ch.VI, sec.4). In the light of such debates, being aware of the different streams in the development of temperance as a concept is not just a pedantic process, but one with wider implications for the interpretation of its use. The relationship of prudence and temperance is just one key area of difficulty, and seeing Hamlet in the light of temperance in FQII brings with it all the knotty and still often unresolved problems associated with interpreting temperance in Spenser's legend of temperance.

\section{Temperance from Aquinas to Hume}

According to the ethical philosopher Alasdair MacIntyre, temperance is far from a stable concept across time. MacIntyre traces the differences between popular Greek senses of sophrosyne at the time of the Greek dramatists (MacIntyre 2), and the philosophical approaches to temperance of Aristotle. For Aristotle, temperance is something that can be learned and acquired as a desirable goal in its own right, a virtue with a teleological purpose. There is an absolute quality of temperance which it is desirable to achieve and which is reached through the active suppression of the appetites by the virtue of continence until the intrinsic and habitual moderation of temperance is reached. "There is in the background a conception of the virtues to each other and more especially to phronesis (prudence), in the light of which the 
choices and preferences of virtuous persons differ systematically from those of the vicious and from those still in the process of moral education [my emphasis]" (MacIntyre 6). This philosophical formulation of temperance is carried into the medieval period through the influence of Aristotle on Aquinas and the schoolmen.

But, MacIntyre argues, by the time we reach the Enlightenment period, any sense of temperance as an absolute virtue has been completely overturned.

Temperance in the philosophy of Hume becomes associated with a different sort of teleology, that of the greatest happiness of the greatest number, and so the Aristotelian and Enlightenment views of temperance are in complete opposition to those of Aristotle and Aquinas. MacIntyre notes that "from an Aristotelian standpoint, it can never be right to weigh preferences in such a way that everyone counts as one and nobody for more than one" (6). For Hume (in the Enquiry Concerning the Principle of Morals LX, ii) temperance "restrains overindulgence in pleasure for the sake of utility" (MacIntyre 10), especially the kind of overindulgence which will "draw ruin upon us, and incapacitate us for business and pleasure" (MacIntyre 10). In other words, one restrains one's indulgence in pleasure to achieve more pleasure, to increase the opportunities for pleasure - the polar opposite of the Aristotelian development of a self-educated approach to an eventually habitual restraint and moderation in relation to all pleasure and pain. What Aristotle and Aquinas see as the purpose of temperance is anathema to Hume.

It follows that to put restraint upon what pleases, as people generally are pleased, and what is accounted useful, as people generally reckon utility, is not a virtue but a vice. Celibacy, fasting, penance, mortification, self-denial, humility, silence, solitude, and the whole train of monkish virtues; for what purpose are they rejected by men of sense, but that they serve to no manner of purpose? (Enquiry Concerning the Principles of Morals, IX,i, qtd in MacIntyre 10)

MacIntyre's conclusion is that virtues such as justice or temperance cannot be seen as stable across time, as "fundamentally conservative, preservative of the functioning" (11) of any society. On the contrary, the virtuous may be at odds with established life, and temperance can be the virtue of revolutionaries. "Any follower of Aquinas would exhibit virtues which are dysfunctional to the common life" in Hume's time, and conversely, in Aquinas' time, "any systematic Humean would be a dysfunctional deviant" (MacIntyre 10). 


\section{Ethics and diversity in the Elizabethan period}

Temperance may not always be a conservative virtue, one supportive of the existing order. If we accept this argument in ethical philosophy, we must proceed with caution as we attempt to understand the temperance of an Elizabethan period that is in transition between the ethical world-view of Aquinas and the ethical world-view of Hume. This caution must apply both to the application of primary sources dealing with temperance and to the evaluation of secondary discussion of Spenser and Shakespeare's treatment of virtue. The recent trend of historical and some literacy criticism of the Elizabethan period has been to undermine any view of the period as homogeneous. Studying the literary and theological discourses of the period, for example, Debra Shuger warns against any underestimation of the diversity and contradictions of its perspectives, not only between writers but within the work of individual writers themselves (Shuger 8). The historical work of Norman Jones, among others, points to the complex diversity of systems of belief at the level of the individual household in the Elizabethan period (32-57). Such diversity is also apparent in views of rules for ethical behaviour.

Norman Jones describes a great shift in the view of virtue of the period to one paradoxically more concerned with outward forms of behaviour, as ecclesiastical sanctions against vices covered previously by the seven deadly sins (sanctions such as confessions, contrition, and penitence) had been removed, and the burden of moderating behaviour shifted to the individual conscience and the two tables of the Decalogue, which gave less clear direction on how to behave in daily life (Jones 134). This gap was filled in part by the official homilies of the church, which (along with many pamphlets of the period) explicitly condemned over-consumption of food and drink, and excess in dress, three core topics of temperance. Preachers also warned against the dangers of moral complacency in the face of the doctrine of election.

Such sermonising and pamphlet-writing was necessary because for the average Elizabethan, Jones argues, once the link between salvation and "works" (that through one's moral actions one might in part merit salvation) had been severed in Calvinist theology, moral behaviour became less of a concern for many (161). Either one was saved anyway, and so did not need to worry about behaviour, or one was reprobate and damned and might as well do as one pleased. On the other hand, for those who believed themselves part of the chosen elect, while moral uprightness might be seen as a sign of such election, an underlying uncertainty could lead to much anxiety about behaviour. The emphasis on election and a total rejection of 
works was a topic of active dispute within the Elizabethan church, with theologians such as Hooker and Whitgift (Jones 186) working actively to limit the effect of the rejection of works in established practice. Such conflict among the leaders of the church was reflected in diversity at the level of the parish preacher, and on the foundations of ethical advice to be offered to parishioners (Jones 174). Or there might be little spiritual and moral leadership at all, a source of great anxiety for the reformed leadership in the church, as Elizabeth refused to redress the problem of an inadequate number of clergy, and actively suppressed any spiritual and moral leadership on the part of lay people in the church, particularly the so-called practice of "prophesying” (Collinson, Elizabethans 242).

The importance of temperance to the Elizabethan period can also be seen to be based less on good spiritual guidance than barely disguised economic imperatives and problems of economic solvency. The Elizabethans needed to consume less exotic imported goods (displayed for example in the shops around London Bridge (Hutson 31)), and to support their own national industries, fishing and the production of woollen goods, for example. Lorna Hutson, in her study of Thomas Nashe, argues that "Elizabethan homilies against gluttony and drunkenness, against idleness, against excess in apparel, and on the benefits of a fish diet (i.e. the sanctity of fasting) were clearly composed in response to the exigencies of economic recovery" $(22-3)$.

\section{Reading Shakespeare in the light of virtue ethics}

Studies such as Geoffrey Miles' Shakespeare and the Constant Romans (1996) show the value of reading particular Shakespeare plays in the light of particular virtue ethics. Miles argues that in the Roman plays, Shakespeare is concerned with intrinsic differences in Seneca and Cicero's treatment of the Stoic virtue of constancy. David Beauregard, in Virtue's Own Feature: Shakespeare and the Virtue Ethics Tradition (1995) reads Shakespeare's tragedies in terms of the Thomist treatment of the cardinal virtues. Miles approaches the Roman plays through Roman ethical philosophy, Beauregard the tragedies through medieval Catholic ethical theology, a view of ethics and psychology that, he argues, was still strongly influential in the Early Modern period. The effect of the work of both writers is to highlight the importance of virtue ethics to the "matter" of the Shakespeare play, but both use different virtue ethics in the process. 
While I will consider Thomist virtue ethics closely in one chapter of this study, and Stoic ethics in another, my overall approach has been more eclectic than that of Miles or Beauregard, because this is what Hamlet seems to demand. The play throws up conflicting clues about which philosophical or theological system it follows. Hamlet scholarship is puzzled about which systems to refer to, a point I will support through a representative sample of positions. Beauregard takes a Thomist position; Eric Plumer (“There's a Divinity That Shapes Our Ends: An Augustinian Reading of Hamlet") takes an exclusively Augustinian line. Alan Sinfield argues in "Hamlet's Special Providence" from the perspective of cultural materialism for an unresolved conflict between Stoicism and Calvinism. The seminal work on cultural materialism in Shakespeare, Radical tragedy: Religion, Ideology, and Power in the Drama of Shakespeare and his Contemporaries, by Jonathan Dollimore, does not treat Hamlet at all. Stephen Greenblatt, in Hamlet in Purgatory, argues for the importance of a yearning in the play for the officially abandoned forms of Catholicism; Michael Neill lays the groundwork for this approach in Issues of Death: Mortality and Identity in English Renaissance Tragedy.

Three articles and book chapters show the possibilities of reading Hamlet from both sides of the religious divide in recent work. Mark C Sweetnam in "Hamlet and the Reformation of the Eucharist" sees the play as mobilising the "extraordinary signifying power of the Eucharist" (1). Jennifer Rust in "Wittenberg and Melancholic Allegory: the Reformation and its discontents in Hamlet" finds a "monstrous parody" (261) of the Eucharist in Hamlet's discussion over worms eating the body of Polonius at Hamlet 4.3.18-25 and a reference to Luther and the Diet of Worms. R. Chris Hassel Jr. in "The Accent and Gait of Christians: Hamlet's Puritan style" finds the language of the puritan preacher in Hamlet's discourse.

D. Douglas Waters outlines the play's Christian frame and references, but argues that these should not interfere with a mimetic reading of the play. My own approach will be that Shakespeare creates a conversation between varied approaches to temperance. Shakespeare is pointing to aspects of classical and Christian virtue in this particular play, Hamlet, because this is appropriate to a virtue strongly classical in some ways and strongly Christian in others. The treatment of temperance naturally invites reference to both the classical and Christian worlds. 


\section{Spenser's eclectic treatment of temperance}

The internal logic of referring to both classical and Christian sources is precisely what we see in Spenser's announced allegorical treatment of temperance. Spenser alludes widely to classical and Christian treatments of temperance, and his critics do the same. Although Spenser's theological allegiances are less open to speculation than those of Shakespeare, scholarly discussion of $F Q I I$ varies in its emphasis on Thomist, Augustinian, classical and cultural materialist lines of thinking about the virtue. Thus, to briefly name a few of these positions, Harry Berger's view of temperance in Spenser (in The Allegorical Temper) is influenced by the Thomist ethical philosopher Josef Pieper (Fortitude and Temperance); Carol Kaske provides a reading of the Mordant and Amavia episode in terms of Augustinian negative suggestibility. Richard Mallete alerts the reader to Calvinist lines of interpretation, and Darryl J Gless reads Spenser's treatment of temperance in terms of Reformed theology. James Nohrnberg argues that temperance should be seen as a "classical" virtue.

James Carscallen's study of Spenser's temperance in The Spenser Encyclopaedia gives us an initial sense of the wide sources on which Spenser draws as he develops his allegory of temperance. Carscallen begins by arguing that Spenser draws on a range of traditions (680). The first of these is Aristotle's view of sophrosyne as moderation in bodily pleasures, and also of sophrosyne as virtue in general, the harmonising of appetite with reason to achieve a mean between excess and defect. The person whose appetites are harmonised is temperate, while one who needs to exercise self-control is continent, as in Stoic doctrine. Self-control is central to Plato's view of temperance - temperance is that aspect of virtue by which the spirited aspect of the soul helps keep the appetites under the control of reason. Carscallen argues strongly for a Platonic aspect to Spenser's view of temperance, including temperance as wisdom and the Pythagorean emphasis on the mathematical or musical character in harmony (681).

As well as classical sources of temperance, there are Christian ones. From the Platonic derives the Christian sense of temperance as heavenly wisdom, and temperance as a virtue of purity and self-denial derived from grace. Carscallen sees the focal emblem of temperance in $F Q I I$ as that of the medieval House of Alma - the body controlled by its ruler the soul (Alma). Similarly Guyon is ruled by his guide, the Palmer, with honour as his goal. Another metaphor for governance in the book is that of horsemanship, a metaphor with Platonic roots. The House of Alma is also a 
harmony of its members, while a failure of such harmony is seen in the humoral excesses of Cymochles, Pyrochles, Mammon and Phaedria, the phlegmatic, choleric, melancholy and sanguine aspects of the soul (680). The varied elements of the early part of Spenser's narrative lack unity and harmony but these elements resolve into a series of opposed extremes closely linked to the binary opposition of concupiscence and irascibility. Carscallen argues that unlike Aristotle's extremes, Spenser's extremes are meant to be brought into harmony through a process in time (noting the etymological link of tempus and temperantia). Guyon, unlike Redcrosse Knight, is concerned to perfect his virtue in the context of time. The integrity of the self is represented in the book by the virginal integrity of the body (680).

Following a line of argument that has become commonplace in Spenser scholarship since Berger's study The Allegorical Temper, Carscallen sees a change in temperance, and the temperance of Guyon, within $F Q I I$, and a movement to an ultimate dependence on Christian grace. Guyon is temperate from the outset, but the book also shows the inherent frailty of the flesh. So Carscallen sees Guyon's temperance as a "lost primeval virtue" (682), and likens his faint and rescue by an angel to martyrdom. "Arthur and Guyon are temperate because they do their best in spite of their frailty" (682). Guyon must prove his temperance alone, like Aeneas and Christ in the wilderness.

The deaths of Mordant and Amavia, associated with original sin, present a more serious challenge than the story of Medina and the governance of Perissa and Elissa, deficiency and excess. Furor and Occasion are similarly seen as simple figures to be defeated, and Mammon and Phaedria's worlds as parodic of care and carelessness. Maleger represents the Pauline body of this death, Acrasia a false world of health and temperance. Guyon may intemperately attack this falsely temperate world in the interests of temperance pursued for the ends of grace. Temperance is thus a virtue allied to holiness but giving humanity its integrity. While on the one hand, temperance, as an intermediate virtue, is a "disagreeable necessity", on the other it can be seen as "creation praised for its excellence, a marriage and incarnation itself," the "body of grace" (682).

\section{Some varied approaches to temperance in Hamlet}

This study is not the first to compare FQII and Hamlet, and I present the study in the spirit of uncovering the underlying logic that leads some critics to naturally make smaller-scale comparisons between the works, and others to discuss particular 
aspects of Hamlet in terms of temperance. The variety in the discussion of temperance in Hamlet tends to reinforce the underlying premise I have presented to this point - that it is temperance as a virtue that brings together a range of literary, philosophical and theological ideas.

James Nohrnberg's seminal 1976 study, The Analogy of 'The Faerie Queene', for example, finds in Hamlet the following natural points of comparison with Spenser's Legend of Sir Guyon, or of Temperaunce. In discussing the allegorical figure Pyrochles in $F Q$ II, Nohrnberg notes: "The pagan is said to be the grandson of Phlegethon, and the rivers of hell were sometimes taken for types of the painful and distressful passions. Thus Pyrochles complains that he is consumed: "damned ghoste / In flaming Phlegeton does not so felly roste" (II.vi.50) (Nohrnberg 303). The player's Pyrrhus in Hamlet is "roasted in wrath and fire" (2.2.419). A few pages later, now discussing the allegorical figures in $F Q I I$ Maleger, Impatience and Impotence, Nohrnberg reaches again for Hamlet.

As something that happens to the mind, as well as to the body, Maleger produces a crisis of doubt. The Renaissance conception of pathological melancholy, as Hamlet reminds us, includes impairment of the will, remorse of conscience, anxiety about the future state, and a susceptibility to apparitions, as well as an obsession with the imagery of death and corruption". (314-5)

Nohrnberg also compares a focus on controlling time in both works, seeing Hamlet as "a man caught between Impatience and Impotence, or Claudius and Polonius" (315).

Each of these brief comparisons contains challenging and different perspectives on the role of temperance in Hamlet. To see Shakespeare's Pyrrhus in terms of Spenser's Pyrochles is to glimpse the strongly non-mimetic character of this Pyrrhus. As he does in the Aeneid, this Pyrrhus exemplifies furor to the point that he is an allegorical figure, a type of revengeful rage. Spenser's Pyrochles represents forces of irascibility that lie latent in the titular hero, Guyon, and must be controlled by him, and a very similar relationship applies between the Senecan stage Pyrrhus and Hamlet - that Pyrrhus is everything Hamlet will become if he succumbs to the raw urge to revenge. The imagery used by both writers is similar, and so is the narrative purpose for introducing the figures, and at similar points in the narrative.

Nohrnberg's discussion of the similarity between the depiction of Maleger and Hamlet's melancholy is interesting in a different way - its effect is to use the mimetic nature of Hamlet to throw light on Spenser's allegorical purposes. What 
Maleger represents in FQII is what we see acted out by Hamlet - thinking about what is said and happens in Hamlet helps us understand Spenser's allegorical purposes, and conversely helps us see melancholy as an aspect of intemperance in Hamlet. The usefulness of the study that follows lies not only, I would suggest, in establishing the internal logic of the treatment of temperance in Hamlet, but in, by so doing, throwing light back on Spenser's prior treatment of temperance, and especially in giving mimetic and dramatic form to ideas represented allegorically by Spenser, helping us to glimpse and understand more clearly some of their complexity. Finally, while I will take a different view of the placement of the mean between impotence and impatience in Hamlet than that of Nohrnberg, that the play suggests the need to find means between extremes again shows the centrality of its preoccupation with temperance.

Eighteen years earlier, in 1958, in Shakespeare and 'The Faerie Queene', Abbie Findlay Potts argued for a series of correspondences between Spenser and Shakespeare's plays, and in particular for a comparison between Hamlet and the titular knight of temperance, Sir Guyon. "Sir Guyon, 'slumbring fast / In senseless dreame' (2.8.4.8-9), is the type of Hamlet, 'laps'd in time and passion'. Both Sir Guyon and Hamlet illustrate intemperance on its negative side; both are, as it were, defective; and to both heaven sends ghostly help" (129). Potts compares the "faire mirrhour" of the prologue of Spenser's Book of Temperance with the players' holding of the mirror up to nature in Hamlet (130), and points to Hamlet's ranting over Ophelia's grave and his mockery of Osric as examples of the intemperance he advises the players to avoid and praises in Horatio (131). Her list of examples of intemperance in Hamlet remains convincing. They include

the intemperate wrath of Pyrrhus against Priam and Hecuba, the drunkenness of Claudius, Hamlet's own defective and excessive passion at the end of the second act, his anger against his mother, rebuked by the Ghost in the Queen's closet, and his soliloquy beginning "Rightly to be great". (131)

More common than direct comparison between FQII and Hamlet is a strand of Hamlet criticism that either directly or implicitly deals with temperance in Hamlet, in the manner of Philip Edwards' notes - already discussed - to his edition of the play (Shakespeare 164). Such criticism uses a range of differing philosophical and theological premises.

Robert Miola's 1992 study Shakespeare and Classical Tragedy: The Influence of Seneca argues for the conflict and interaction of the Stoic ideal of 
apatheia and the active impulse to Senecan revenge in Hamlet. Miola sees Hamlet's advice to the players as intrinsically Stoic.

Hamlet's advice to control passion and to beget temperance expresses fundamental Stoic principles and resembles the similar admonitions of Seneca, Epictetus, Marcus Aurelius, and their descendants. A conventional Stoic topos, the storm metaphor, recalls the similar phrase, "some whirlewind and tempest of misfortune', appearing in Stradling's translation of Justus Lipsius (1594). What is more, the Stoical idiom of Hamlet's recommendation reverberates throughout the play and defines his own dilemma. After the reappearance of his father's ghost, he says to his mother, 'My pulse as yours doth temperately keep time' (III.iv.140). The echo of his earlier advice, following hard upon his extreme agitation, reveals Hamlet's archetypally Stoic struggle with ...passion. (Miola 55-6)

What is implicit here, as Miola links Shakespeare's use of "temperance" and "temperately", is that the Stoic struggle with passion is the struggle of temperance. After considering the focus on passion in Hamlet's advice to the players on their initial arrival in Elsinore, the treatment of passion in the scene of the Player King and Queen, in Hamlet's praise of Horatio and in Hamlet's apology for his 'tow'ring passion' towards Laertes, Miola points, like Edwards, to the irony of Hamlet's advice-giving to the players:

At times Hamlet strives to enact the great passions of the Senecan avenger; at others he subscribes to the Stoic idea that passion is an infirmity, an emotional perturbation, ephemeral, savage, extreme, cruel, rude, not to trust. In context, the Stoic advice to the players has a certain irony: he who struggles to express his great passion in action warns against the false passion of overacting. (55)

In a series of recent articles, Eric P Levy teases at the issue of the role of reason in Hamlet, drawing on Aristotelian and Thomist sources through Etienne Gilson's History of Christian Philosophy in the Middle Ages. His discussion often parallels Lynette Black's discussion of prudence in FQII, previously cited, and this congruence of concern is explained if temperance is the underlying topic. In "What should we do?: The Predicament of Practical Reason in Hamlet," Levy's concern is with the reason that leads to moral action. Levy argues that in the fallen world of Hamlet, a world signalled by the echo of the postlapsarian homo claudans or limping creature in the naming of Claudius, "practical reason cannot properly perform its function of directing action" (48). So, in Levy's view, a breakdown in the Aristotelian / Thomist chain - deliberation leads to choice and consent (consilium, electio, consensus) - leads to "rash" or "mad" behaviour (49). In the "To be or not to 
be" soliloquy, Hamlet's deliberation rejects both of two choices, and this failure of consilium leads not to consensus but a weakening of the will (50).

In “'Things standing thus unknown': The Epistemology of Ignorance in Hamlet", Levy turns to the Socratic association of ignorance and self-knowledge, an association that leads Levy to sophrosyne (or temperance). The knowledge Hamlet most urgently needs is self-knowledge, and ironically he is the source of selfknowledge in others - Claudius, Gertrude, and Laertes. In Plato's Charmides selfknowledge

requires a "man to know what he knows and what he does not know" (Charmides, 167a). Here, awareness of ignorance awakens the commitment to gain knowledge; for in this context ignorance is synonymous with "emptiness... of soul" (Republic, 9.585b) or malady: "for you will do me much greater benefit if you cure my mind of ignorance than you would if you were to cure my body of disease" (Lesser Hippias, 373a). Once the defect of ignorance is recognized, enrichment of self-knowledge becomes the defining purpose of life. Indeed, according to Socrates' celebrated dictum in the Apology (38a), "life without this sort of examination is not worth living." (200)

This brings Levy to the sophrosyne of the Charmides:

It is the virtue enabling character to subdue the importunities of the lower self (variously denominated in Hamlet as " nature," "blood," "passion," or "the worser part" $[1.5 .12,3.2 .69,3.4 .159])$ and thereby actualize the higher self. Through sophrosyne, right moral "order and arrangement" of character is achieved: "the temperate soul is the good" (Gorgias, 506e). As a result, personal identity is literally rationalized - ordered, that is, in conformity with the rational principles of balance and proportion whereby "excess in either direction" from the mean is restrained (Republic, 10.619a). Thus construed as respect for limits, sophrosyne enables the self-knowledge, enjoined by the Delphic inscription, Nosce teipsum (Know thyself), cited by Socrates in the Charmides. (201)

Going back to the Greek roots of temperance Levy is, almost explicitly, arguing that Hamlet is concerned with temperance. Levy's focus, however, tends to be less on the nature of temperance as self-control than on the consequences of lack of knowledge, and the conclusions of this dissertation diverge from his. For Levy, Hamlet is defined by the need to know himself and for others to know him. He also "strains against the limitations of ignorance" and is "characterized by the enigmatic gestation of his own thought" (201). Levy's ultimate conclusion is that Hamlet "achieves epistemological self-control through acceptance of the limits of knowledge, an attitude echoed in his last four words: "the rest is silence"' (209). I am less convinced that these final words so unambiguously convey self-control in any form. 
In "The Problematic Relation between Reason and Emotion in Hamlet", Levy has developed his understanding of the role of reason in Hamlet to the point of seeing reason as itself a source of emotional response. Although Levy (6) sees Hamlet's advice to Gertrude and his praise of Horatio as examples of Aristotle's view that "the appetitive element in the temperate man should harmonize with the rational principle (Aristotle 15-16)", and Aquinas's agreement that "it pertains to the perfection of man's good that his passions be moderated by reason (I-Ii, q.24, a.3, resp.)", he argues with respect to Hamlet himself that continence is ultimately associated with the role of reason not in moderating emotion (as Aristotle emphasizes), but in transforming it.

As previously discussed, David N. Beauregard's study Virtue's Own Feature: Shakespeare and the Virtue Ethics Tradition looks at a range of Shakespeare plays through the lens of Aquinas and the ethics of the Summa Theologiae. Even though Beauregard sees Hamlet as primarily concerned with the virtue of justice (because of its focus on revenge), he still discusses Hamlet's advice to the players in his introductory chapter on "Aristotle and the rest" in terms of both "avoiding extremes of excess and deficiency in order to achieve the golden mean of virtue, in this case the virtue of temperance," and (in relation to not overstepping "the modesty of nature") to "the virtue of modestia, which has to do with the regulation of external bodily actions, either serious or playful. Modestia is particularly appropriate to the exercise of temperance, being recommended here as central to the profession of actor/player" (Beauregard 54).

Temperance in Hamlet has thus been seen over a period of time by scholars in relation to the portrayal of temperance by the protestant poet Spenser, or through Senecan Stoicism, or Aristotle and Aquinas (or a further rejection of them). It has also been more recently seen from the perspective of cultural materialism. John Guillory in "“To Please the Wiser Sort': Violence and Philosophy in Hamlet," notes that Hamlet is concerned with both sexual incontinence and the incontinence of anger. In his article he chooses to consciously overlook the sexual and focus on the social parameters surrounding the sublimation of aggression. Guillory sees in Shakespeare's treatment of violence a pre-Cartesian materialism (and so represents a movement in recent Shakespeare scholarship to see the period more from the direction of Hume than Aquinas), focussing on the shadow of the Essex rebellion falling on Hamlet. Guillory sees the "modernity" of the Elizabethan courtier "in the fact that they had to resist the impulse to resolve disputes within their class stratum 
by an immediate and unreflective resort to violence. This internalized self-restraint was the principal mechanism of social control in a court that dispensed with the armed retainers of its medieval predecessors" (97). Guillory gives the example of Essex almost drawing his sword on Elizabeth as a case when such internalized selfrestraint broke down, and then makes the analogy with Hamlet's situation in Hamlet. "The sublimation of politics into culture" (100) is reflected in the "Mousetrap" play. Guillory's focus on irascibility is intrinsically about self-control and sharpens, for our purposes, our sense of the latent and sometimes overt violence of the play, the irascibility for its own sake represented in Spenser by Pyrochles and in Shakespeare by Pyrrhus.

\section{Finally, in Passion's Triumph over Reason: A History of the Moral} Imagination from Spenser to Rochester (published in 2007) Christopher Tilmouth places a treatment of rational self-control in FQII next to a similar treatment of Hamlet. Tilmouth does not (as I have done) see Hamlet as a systematic treatment of temperance. Tilmouth's wider argument is that "an austerely rationalist model of self-governance, one centred on ideas of psychomachia and a hostility to the passions," (a model represented in his study primarily by The Faerie Queene) is replaced by alternative traditions "grounded in Augustinianism and a reinterpretation of Aristotle", traditions demonstrated in Herbert and Milton, and finally by the time of Hobbes by "a libertine ethic of indulgence" (1). Tilmouth is thus tracing a shift to a valuing of emotions and passions in their own right across a hundred year period.

Tilmouth finds Spenser's concern with the backsliding flesh and the asceticism of Guyon's continence in Hamlet: “the Prince vilifies the flesh and man's passions, embracing the very same austere ethics elsewhere celebrated by sixteenth century moralists" (3). This is particularly so in Hamlet's attack on his mother. "To save [Gertrude] is to begin to save himself and Denmark - or so Hamlet imagines" (111). In contrast to Hamlet's unleashed moral passion at this point in the play, Tilmouth finds (rather like Eric Levy and following Miola's treatment of Senecan Stoicism in Hamlet previously discussed) a use of reason to stir up passion and a valorizing of Senecan fury that amounts to a break with the (as Tilmouth styles it) "pyschomachian" model of Spenser and the moralists of his period. For Tilmouth, Shakespeare's treatment of reason and the passions thus both reflects and moves away from that of Spenser. I see a much stronger convergence in the treatment of self-control in the two works, explaining the shifts as those belonging to a pendulum swing between irascibility and concupiscent sloth and back again. 
Tilmouth points to a "Calvinist" vilification of the flesh and moral backsliding in both this aspect of Hamlet and in FQII, and describes the Calvinist view of dependence on grace. He limits Calvinist grace in FQII to something that both only appears "fleetingly" and at the same time validates rationalist endeavours to obtain virtue. It is this limitation that most clearly distinguishes his approach from my own. Tilmouth transfers what he terms a more Augustinian approach to grace to the period of Herbert and Milton. Instead he measures the progress (or, as he sees it, lack of progress) of Spenser's titular heroes against the ideal of Aristotelian habituation. For Tilmouth, the Aristotelian ideal of temperance is most strongly represented in Guyon's response to avarice in the Cave of Mammon. Tilmouth allows Arthur to represent Christian virtue underpinned by grace (without, however, identifying this virtue with temperance), but still concludes that "co-operating grace is not, perennially, a sine qua non of virtuous attainment. Rational autonomy - the proposition that the agent has the capacity to govern himself unaided - is the prevailing assumption, if not of Book I, at least of the later books of the poem" (72). Thus while we traverse similar content and sometimes converge in our interpretations - as on incontinence and intemperance in the Phaon / Phedon episode - Tilmouth's conclusions are ultimately opposed to mine. My extension of the theological into the episodes of the Castle of Medina and the portrayal of Alma are symptomatic of this - as is my rejection of a once standard view (a view accepted by Tilmouth) of Guyon's faint as testifying to his lack of physical sustenance. I read this episode in the light of Augustine's prayer in Confessions XII, seeing Guyon as an Augustinian parvulus fallen from the nest of faith and requiring the spiritual sustenance of the Word.

While Tilmouth canvasses the positive emotions of the wider Faerie Queene, it seems to me he underestimates their function - I see them as a major chord resonating against the minor keys of Spenser's subtle and acute portrayal of human weakness and depravity. Importantly, I believe, for $F Q I I$, the theological virtue of hope is one of these emotions.

In accepting FQII, i. 58. 1-5 as "Spenser's definition of temperance" (51) (and in so doing identifying Spenser's view of the nature of virtue with the humanist Erasmus) Tilmouth fails to appreciate this early "definition" is much challenged within FQII. While, I have argued, it is impossible to place Spenser on a continuum between, say, a Calvinist like William Perkins and a proto-Laudian like Richard Hooker, Spenser must have been acutely aware of how provocative any valuing of 
the primacy of reason would have been in a period of reformation strongly concerned to reject the doctrine of justification by works (as seen in Articles XII and XIII of the Elizabethan articles of faith). A "proposition that the agent has the capacity to govern himself unaided" (72) would be equated with justification by works by many of Spenser's contemporaries. Influenced (unlike Tilmouth) by the scholarship of Carol Kaske, I have been prepared to recognise the concept of Augustinian negative suggestibility (and thus the importance of the will) in the opening sequences of $F Q I I$, thus taking my discussion of temperance in $F Q I I$ in a different direction. Most importantly it contradicts Tilmouth's view that “[c]rucially, for all man's imperfections, the value of the rule of reason per se, of Spenser's psychomachic mission, is never challenged in this poem" (73).

These examples can only be representative of a long list of treatments of reason and the passions in Hamlet and in Hamlet as seen in relation to FQII. Beauregard, working directly from Aquinas, and Guillory, approaching the period from the perspective of cultural materialism, demonstrate two extremes of current scholarship. In attempting to steer my path between this Scylla and Charybdis, I have erred, temperately, on the side of seeing the influence of the past as requiring more weight than a projected movement into the future, but not, I trust, to the extent of failing to recognise a process of change in operation.

\section{Structure}

Each chapter of this study takes a different approach to temperance, using different strands in the historical development of the concept, and drawing on what have seemed the most relevant primary and secondary sources to do so.

The chapter immediately following this establishes in a preliminary way some of the breadth of the concept, and popular access to the concept in the Elizabethan period, and examines some issues of definition. Chapter Three looks at the roots of the Greek concept of sophrosyne, the early Socratic association of temperance and self-knowledge in the Charmides, and the treatment of temperance and self-knowledge in Greek tragedy.

Chapter Four moves to the most Protestant approach to both works, seeing temperance in terms of the injunction of the Easter Tudor homily for revenge on the weaknesses of the flesh, and thus in terms of abject and fallen human nature. Chapter Five then examines the problem of conflicting classical and Christian frames in both works, with a focus on grief and suicide. Chapter Six looks outward, seeing 
temperance in political and social contexts, in relation to the Aristotelian mean, the via media of the Elizabethan church and social decorum. Chapter Seven looks inwards to emotional self-control and the originally Platonic division of the soul into rational, irascible and concupiscent elements. It applies Aristotle and Aquinas to the presentation in both works of conflict in the soul. Chapter Eight sees FQII, and Chapter Nine, Hamlet, in terms of their reference to the epic and epic journeying. These chapters make comparisons with Augustine's Confessions, and Cristoforo Landino's exegesis of the Aeneid as the journey of a soul tossed neo-Platonically between continent and incontinent urges in the quest for ultimate wisdom. 


\section{Chapter Two:}

\section{Modern and Renaissance temperance: issues of definition}

When Edmund Spenser dedicated a whole book of his allegorical poem The Faerie Queene to the virtue of temperance, he drew on an old and rich vein of thought, one of immense importance in the western intellectual tradition. Temperance reaches back to the precepts of the Seven Wise Men and is extensively treated in Greek tragedy. Definitions of temperance are tightened by the great Greek and Roman philosophical schools. Temperance is both resisted by and assimilated into Christian thought in the early Christian period and then accommodated by the systemisations of the Middle Ages. Finally it becomes part of the reshuffling of ideas that occurred in the Renaissance, with the rediscovery of some elements of the classical. Because of these many historical shifts, we must draw on models like that of Wittgenstein's family resemblances (there is no one definition that can account for all occasions of the use of the word "game", but family resemblances can be found between different types of games (Wittgenstein 27)) to account for apparently disparate aspects of the virtue. In the case of temperance, we have to accommodate such apparently disparate ideas as the role of the 'scourge', rules for appropriate dress and the use of cosmetics, Platonic assimilation to God, rules for the middle path in oratory, the Aristotelian mean of virtue, credibility in an intellectual argument, arrangement of music and pleasant weather.

The metaphor of the varied streams in a braided river is a helpful way of making sense of, and accounting for, some of this conceptual complexity. Temperance as a concept arises from one spring in the high mountains of Greek thought, but as it travels down to the plains and runs across a bed of stones, it spreads out into a set of streams that sometimes divide and run separately for a period, and then reconnect or cross over each other and recombine and become wider and narrower in different combinations.

Very broadly, the pattern followed by this braided river is the following. Sophrosyne has the primary sense of "soundness of mind", and this relates to the inner unity and harmony of the individual (North 3). A second meaning of sophrosyne, that of moderation, attaches to the response of the virtuous person encapsulated philosophically in Aristotle's doctrine of the mean. Temperance in Aristotle becomes a moral rather than an intellectual virtue, to do with behaviour 
rather than understanding (North 197-211). When the Greek sophrosyne is translated, primarily by Cicero, into the Roman temperantia, a further layer of connotation is added to the virtue, that of "proper mixture" (North 283), applied to human psychology. In Stoic thought decorum - proper social behaviour - becomes an aspect of temperance. The early Church Fathers associate temperance with purity and chastity (North 312-380). Throughout the development of the virtue there is a process of narrowing its range from a wider intellectual virtue that encompasses prudence and self-knowledge to (at the narrowest extreme) the moral virtue that controls only the desire for pleasure. The development is not uniform, however, and philosophers and theologians alike may refer to the wider sense of temperance in one work and the narrower in another. Spenser's allegorical treatment of temperance often reflects this historical complexity, and aspects of temperance also divide off and recombine in unexpected ways within his allegory.

This chapter will deal with the difficulties of adequately defining temperance, looking first at some modern usages, and then at some Early Modern treatments of temperance.

\section{How Hamlet's advice to the players still speaks to us}

The noun temperance is associated, even today, with pledges to abstain from the consumption of alcoholic liquor, the heritage of the Victorian Temperance Movement. But the concept that gained its initial importance in the development of the Athenian polis retains its resilience and importance in contemporary intellectual debate. One example that can be pointed to is the role in social and political discourse of "moderate" as a noun to designate a person who does not take an extreme position, and "extremist" to designate a person who does. "Moderate" "political moderate", "economic moderate", "religious moderate" and so on - is a term that may carry both approbatory (as reasonable, sensible) and disapprobatory (as conservative, timid, reactionary) connotations, while "extremist" - "political extremist", "religious extremist", "economic extremist" - tends to be pejorative (with "radical" as a sometimes approbatory term). Moderation in all things, and selfcontrol in moral and social behaviour, remain central to our way of seeing the world, even though the noun temperance has gone out of fashion through a narrow Victorian application of its meaning.

In the final weeks of the 2008 Presidential race in the USA much editorial and op-ed comment focussed on issues of self-control. This included the self-styling 
of Barack Obama as calm and unshakeable, something seen as a strength by his supporters, on the one hand, and as a Machiavellian weapon of attack by some commentators on the other (as it is in Patrick Healy's piece in the New York Times of 16 October: "Staying cool and irritating your opponent"). The McCain / Palin campaign came under attack for encouraging emotional extremism, and for praise when they moderated this approach. The verb "temper", in the sense of moderate or tone down, was common in election reporting (with such headlines as "Palin tempers attacks"). This sort of usage reflects a long tradition of temperance that goes back to classical rhetoric, where establishing the temperance of the speaker is an integral part of establishing moral character and so credibility. In classical oratory, including that of the courtroom, the moral character of the speaker and a temperate style of delivery (in a famous example, not taking the hand outside the toga) and modesty (as with the "unaccustomed as I am to public speaking" trope) are first established, and then the intemperance of the accused or person under attack.

In intellectual discussion, avoidance of extremes is still central to our methods of establishing the truth of intellectual topics, and Shakespeare criticism provides example of this. For example, when James Cunningham in Shakespeare's Tragedies and Modern Critical Theory criticises the attacks of Jonathon Dollimore's Radical Tragedy on previous humanist criticism, he uses the language of temperance and extremes: "Had he concentrated on neo-Bradleyans such as Bower and Honigmann, his case would have been more persuasive; as it is, it is compromised by being pressed beyond reasonable limits. A more temperate judgement is provided by Dollimore in Political Shakespeare (1985) [my emphases]" (Cunningham 49-50). It is more temperate, in Cunningham's opinion, because it is "much more consonant with the evidence [my emphasis]."

Cunningham's use of the language of temperance in intellectual debate, like Hamlet's advice to the players, raises a raft of issues. First, there is the issue of the relationship of intellectual temperance with the truth of the argument. Cunningham is implicitly claiming a sort of tipping point, after which if an intellectual claim is not sufficiently moderated it loses credibility. This idea runs parallel to Hamlet's advice to the players, in which histrionic delivery, at a certain critical tipping point, not only loses efficacy but does so by moving away from the truth of nature. Ironically a less strained intellectual argument, or more temperate theatrical delivery, strengthens a more radical case or purpose. 
In contemporary discourses, whether those of literary criticism, or politics, or economics, or other fields of intellectual debate, to challenge innovative ideas may have the positive connotation of reasonableness, on the one hand, or risk the label of "moderate" in a negative or pejorative sense, in the sense of the person who rubs off the sharp edges of the argument and smoothes difference into similarity. To be "moderate", in this sense, is to be essentially conservative. The "extremist," the radical, is the one who causes intellectual (or political) change to happen. The debate between the moderate and the extremist or radical, then, becomes one of who is closer to the truth, the innovative thinker or the one who "tempers" the position of innovation; and whether they are seen in a positive or negative light resides with the onlooker's view of the truth of the argument (and so a corresponding set of intellectual beliefs). The problem may then become whether or not the holder of beliefs is, in MacIntyre's phrase, a "dysfunctional deviant" or revolutionary in relation to the commonly held intellectual beliefs of the time. The issue is seen in Elizabethan politics (as we will see) in discussion of who is "forward" and who "froward" in relation to a relative mean.

\section{Contemporary definition}

The definitions of the Oxford English Dictionary, with accompanying etymological citation from the Tudor period, prove very helpful in establishing the conceptual envelope of temperance. The $O E D$ definition has four distinct categories of temperance. All are of importance to any study of Early Modern English literature (except for the particular application to the Victorian Temperance Movement already discussed). They cluster together more naturally for an Elizabethan readership than they do for us.

The central definitions apply to temperance both in a range of daily contexts, and to more philosophical senses of the word. The general category for temperance given by the $O E D$ is: "The practice or habit of restraining oneself in provocation, passion, desire, etc.; rational self-restraint. (One of the four cardinal virtues)." The definition then divides into two parts.

1a is closer to the broad sense of intellectual temperance already discussed: "Self-restraint and moderation in action of any kind, in the expression of opinion, etc.; suppression of any tendency to passionate action; in early use, esp. self-control, restraint, or forbearance, when provoked to anger or impatience." Hamlet's advice to 
the players, if paradoxically because it concerns extreme emotion, clearly comes under this first category. Hamlet's purpose - that of provoking Claudius to anger shows an application of the second half of the definition, as an attempt to override temperance as self-control, restraint or forbearance. Claudius shows such restraint when confronted with Laertes and his mob (4.5.111), and Gertrude exhorts such temperance in return from Laertes (4.5.117). The $O E D$ cites $F Q$ I.viii.34 as its example: "He...calmd his wrath with goodly temperance." Much of the action of Hamlet, in fact, revolves around moments of lack of self-control, or more or less successful attempts at self-control, of these sorts, involving anger or forbearance. Seen in the light of this definition, when Hamlet says "[b]ut break, my heart, for I must hold my tongue" (1.2.159), he is making a quite orthodox expression of a need for temperance. (It is interesting to note that under this category, the $O E D$ also gives an example of the use of temperance as decorum in dress, in a sermon of 1511 by the English churchman John Colet: "The lawes that commaunde sobernes... and temperance in adournynge of the body").

The second subdivision is: "Self-restraint in the indulgence of any natural affection or appetency; moderation in the pursuit of a gratification, in the exercise of a feeling, or in the use of anything; in early use often = chastity." It is with this aspect of temperance that Spenser's Guyon is most closely concerned in the Bower of Bliss, and with which Hamlet is most concerned in the behaviour of his mother and uncle. The $O E D$ gives an example from the English humanist Abraham Fleming's 1576 A Panoplie of Epistles: "She forgetteth temperance and waxeth incontinent", and these are words Hamlet could easily have used to describe Gertrude's behaviour in marrying Claudius, or the potential risk that Ophelia can escape only by joining a nunnery. A citation in the $O E D$ from Philemon Holland's 1603 translation of Plutarch's Moralia contains both the sense of appropriate measure, and the sense of governance of the appetites: "When it ruleth and ordereth our lust or concupiscence, limiting out a certaine measure, and lawfull proportion of time unto pleasures, it is called Temperance."

It will be the purpose of much of this study to explore further the historical and philosophical backgrounds, and so their relevance to our works, of the temperance described in these last two definitions. The etymological note to the $O E D$ definition of temperance provides a useful signpost to this work. This note states that the Latin temperantia 
(whence F. and Eng. temperance) was used by Cicero to render Plato's sophrosyne, 'soundmindedness, prudence, moderation, sobriety, self-control', in Plato and in the Stoics, one of the original four (cardinal) virtues... rendered in L. by Jerome and Augustine prudentia, iustitia, fortitudo, temperantia; also in Albertus Magnus, Aquinas, and the medieval writers generally, and in the med. L. version of Aristotle's Nicom. Ethics. Thence the use of temperaunce by Grossesteste, and the earlier Eng. use.

The meanings of 1a in the $O E D$ definitions correspond to the Greek sophrosyne, while the meanings in $1 \mathrm{~b}$ correspond to the Greek enkrateia, "self-mastery or restraint, esp. of certain sensual impulses, in L. commonly, continentia."

This apparently simple explanation hides a wealth of complexity and some of the landmines of this topic. As the $O E D$ note recognises, in Greek usage temperance is often directly equated with prudence through the etymological basis of sophrosyne in the health of the "phrenes" (a mysterious organ associated with the mind). This relationship is critical for Hamlet, elucidating why health of mind, and the dangers of loss of health of mind, losing contact with reality, would naturally be a focus of a play concerned with temperance. It also explains the role of temperance as a sort of meta-virtue, a virtue that can be equated with virtue itself, and why rational selfcontrol is so integral to temperance, even when prudence is placed at the top of a hierarchy of cardinal virtues by Plato, Cicero and Aquinas, and temperance at the bottom. Particularly for Plato, temperance is a virtue that is concerned with the proper functioning and harmony of the soul as a whole. Sobriety in its widest sense is perhaps the best synonym to convey this sense of temperance as sophrosyne, a synonym that arose naturally in Latin because of the closeness of pronunciation of the Greek adjective sophron, and the Latin sobrius (North 264). We may be most familiar with this sense of sobriety from the words of The Form of Solemnization of Matrimony which in the Elizabethan period (and in a very similar form in modern Anglican weddings) states that marriage should be undertaken, "reverently, discreetly, advisedly, soberly and in the fear of God," with "soberly" here having connotations of a reflective and calm state of mind. In Hamlet, this calm, poised state of mind is best seen in Hamlet's speech praising Horatio's temperance, a speech which becomes a kind of touchstone for all Hamlet's wild swinging away from, and attempted returns to, such a "soundness of mind."

The $O E D$ etymological note also lists some of the variants in Biblical translation into English, where both temperance and continence can stand for enkrateia, and abstinence and chastity also appear as synonyms of it. It is important to note that the Aristotelian distinction between temperance and continence is not 
necessarily reflected in the range of translations available in the Elizabethan period. Direct uses of continence and other synonyms (of which sobriety is an important one) may disguise a direct or indirect reference to temperance. To be chaste can also convey a particular state of mind synonymous with temperance, as well as a more narrow sense of the control of sexual impulses.

\section{Some other uses of temperance in ethics and literature}

The other aspects of temperance seem more immediately familiar but also have very long historical roots. $O E D$ 2: "The avoidance of excess in eating and drinking; esp., in later use moderation in regards to intoxicants, sobriety. Now often applied to the practice or principle of total abstinence from alcoholic drink; teetotalism." We can disregard the aspect of total abstinence as the one already mentioned that belongs to the nineteenth century Temperance movement previously discussed, and the definitions in 2.b. and 2.c. (which I will not cite) relate to this. But it is wrong to overlook the importance of the early part of this definition to our discussion. Moderation in drink and eating was always part of the usage of sophrosyne in daily Greek life (North 21), of temperance in its popular sense, and a preoccupation with both is reinforced in a swath of Elizabethan moral pamphlets. That it is a key of temperance for Spenser is made clear when in FQII Guyon's triumphal and purposeful entry to the Bower of Bliss is marked by his overturning of a winecup held up by a figure called Excesse (II.xii.56). Therefore, once we begin thinking of Hamlet in terms of the virtue of temperance, it should not come as a surprise that Claudius marks Hamlet's forbearing agreement to the request that he stay in Denmark with a promised drinking bout, in which cannons will sound (1.2.126), and, on their doing so in a subsequent scene, that Hamlet denounces the Danish tendency to drunkenness and its negative effect on the national reputation (1.4.16). More importantly still, Hamlet complains that his father was murdered by Claudius when he was "full of bread" (3.3.80) and so unshriven of his sin of gluttony, and this then hints at a habitual intemperance in the older as well as the younger brother.

$O E D$ 3a is "The action or fact of tempering; mingling or combining in due proportion, adjusting, moderating, modification, toning down, bringing into a temperate or moderate state." This category owes its place in the braided river of temperance to the definitional shift from the Greek sophrosyne to the Latin temperantia, and the Latin verb temperare with the underlying idea of mixture (North 262). When Horatio commands Hamlet in Act One Scene Two to "season 
your admiration for a while with an attent ear" he is requesting this form of temperance, a toning down of amazement and excitement with attention. The verb "season" here could easily be replaced with "temper." Horatio himself is the consequence of such temperance, his "blood and judgement are so well commeddled" (Q2 has “comedled” and F “co-mingled”), and it is partly this phrasing that gives this praise its Stoic connotations. Cicero was in part responsible for the development of Latin synonyms for sophrosyne (North 268). Mixture is a conceptual aspect of temperance that is, I suspect, often invisible to the modern reader as an overt expression of temperance. The $O E D$ also gives an example of a temperate political constitution, and so seeing Hamlet in terms of this aspect of temperance provides a cogent explanation for Shakespeare's reference to election in Denmark. The $O E D$ reference is to James Dalrymple's 1596 translation of Leslie's History of Scotland: "A Forme of commoune weil, quhair the people haue the hail authoritie, ...bot wt sik temperance, that chief vpon thair king, and counsel...the Repub. does depend." Although without the aspect of election, the England of Elizabeth 1 and James VI also had a temperate or mixed constitution, which required the monarch at inconveniently frequent intervals to refer to the people through Parliament.

$O E D 3 \mathrm{~b}$ is "A tempered or properly proportioned consistence, constitution of state; temperate condition, moderateness." The OED gives an example of bodily balance from 1533 in Sir Thomas Elyot's The Castel of Helth: "They be in the highest degree of heate and drithe, aboue the iuste temperaunce of mannes body." This entry helps us realise how clearly Gertrude's injunction is a request for temperance, including both mixture and toning down in that properly proportioned temporal sense: "O gentle son, / Upon the heat and flame of thy distemper / Sprinkle cool patience" (3.4.121-3).

$O E D 3 \mathrm{c}$ is "The keeping of time in music." If we think about this, we realise how significantly it is used by Hamlet in his defence of Gertrude's accusation of ecstasy: "My pulse as yours doth temperately keep time, / And makes as healthful music" (3.4.141-2). To be played on like a pipe through false flattery will not, however, result in healthful music, as Hamlet tells Guildenstern (3.2.333). False harmonies of music are an important ingredient of Spenser's parodic bower in FQII, and part of their parody relates to the higher harmony of the spheres.

OED 4 gives the definition related to weather: "Moderate temperature; freedom from the extremes of heat and cold; mildness of weather or climate; temperateness." In Shakespeare's quintessential Sonnet 18 the loveliness of a young 
man, and by implication his character, is compared to the temperate nature of a summer's day. When Spenser's Bower of Bliss is marked by its temperate climate, a problematic relationship is developed between the temperance of nature and moral behaviour. The temperateness of climate then starts to become more central to the action than we may have allowed. Shakespeare's Tempest is set in an island "of subtle, tender and delicate temperance," while Shakespeare's Hamlet begins in an Elsinore of such intemperate cold that it makes men sick at heart.

\section{Recognising temperance}

As we have seen, terms can cross over in translations from Greek and Latin into English, in translations of the Bible, different synonyms may be in play, or have taken on completely opposite connotations (in terms of broad or narrow) from the original Greek or Latin usage. Sometimes the concept of temperance is at issue, with no useful vocabulary signposts like those provided by Shakespeare of "temperance" and "temperately", or without synonyms like moderation, chastity, sobriety, continence, abstinence. Unless we are aware of the shape of temperance in the period of the source we easily miss associated connotations, and these can vary within the work of the same writer. For example, as Helen North points out, in De Inventione, Cicero associates temperance with the subdivisions, "continentia, clementia, and modestia" (271), subdivisions drawn from the Greek Stoics. In De Officiis (a work that Shakespeare would probably have studied at school (Baldwin 590)), temperance includes "verecundia, ornatus vitae, temperantia, modestia, omnis sedatio perturbationum animi, modus rerum and decorum" (269). This introductory section of the study will conclude with an attempt to convey something of the resilient conceptual envelope of temperance for Spenser and Shakespeare's period through works that cluster associated ideas of temperance.

\section{Renaissance views of temperance}

The work that follows does not aim to be comprehensive, but rather to deliver a representative flavour of Early Modern temperance. Two recent studies exemplify the difficulties involved in any narrowing of the domain of temperance in the late Elizabethan / early Jacobean period and so its application to Hamlet.

Joshua Scodel, in Excess and the Mean in Early Modern English Literature (2002), makes a conscious decision to restrict his treatment to the primarily 
Aristotelian mean. He talks about the golden mean, the mean and extremes, mediocrity (as a synonym of the period for the mean) and moderation, but in his introduction does not often refer to either temperance or self-control. An exception is when he talks about Milton's treatment of Adam and Eve, arguing that "Milton has his Edenic couple discover in temperate self-restraint both a moral discipline and the source of truest pleasure" (17). In his final chapters Scodel deals with early modern treatments of erotic excess, drinking and the pleasurable restraint of Milton's Paradise Lost. But even with these foci Scodel is primarily concerned with the mean and extremes in a public context, and the early chapters particularly focus on the use of the mean in the religious and political contexts of the period.

\section{Michael Schoenfeldt's 1999 study, Bodies and Selves in Early Modern}

England, also deals with matter that falls into that encompassing conceptual envelope that is temperance. Schoenfeldt looks at the imagery of the containment of the self in the period, and the humoral psychology that makes temperance, selfcontrol and the mean repeated touchstones of reference. Schoenfeldt makes this point about Galenic medicine:

In its emphasis on temperance as a central strategy for the maintenance of physiological and psychological health, locating both at the mid-point of unhealthy extremes, Galenic physiology provides a compelling model of just how good health could emerge from good living. As temperance became a central ethical virtue for the Renaissance, health assumed the role of a moral imperative, just as it still is in many ways for us. (Schoenfeldt 7)

Both works study what Spenser would have considered temperance, and temperance in the Early Modern period; but there is little overlap between the outward-looking political and social focus of Scodel's work and the focus on interiority of Schoenfeldt's. Both also acknowledge the difficulty of establishing terms in a period of competing influences. Scodel comments on the eclecticism that brings the Aristotelian mean and Stoic apatheia together in writers like Plutarch, Cicero, Seneca and Augustine, and the pattern of early modern syncretism that tends to dissolve some of the distinction of the sources (2-3). He also argues for the mean to be seen as "a quintessential example of what post-Wittgensteinian philosophers call a "fuzzy" concept whose borders are hard to define" (3). The result in the period was, Scodel argues, that "the ideal of the mean thus became an intense source of conflict," and Aristotle's proximate extreme could easily displace the mean (4). He gives the debate about means and extremes of grief in the period as an example. Schoenfeldt, by contrast, is developing an understanding of "the invasion of social and 
psychological realms by biological and environmental processes" (8) in the description of the self in writing of the period and argues:

The philosophical question which such a notion of self entails, for us and for the Renaissance, is just how the physical body and non-physical spirit interact. The Renaissance inherits and elaborates an enormous dissonance and inconsistency in the available doctrines of the relationship between bodies and souls, and between reason and the passions. (8)

Any attempt to recapture a Renaissance understanding of temperance must incorporate the approaches of both Scodel and Schoenfeldt, to demonstrate an understanding of the mean and extremes in social, religious and political contexts, and of self-control in terms of interiority and in terms of the dissonances of the period about the relationship of body and soul, reason and passion. As both writers indicate, this is not an easy task. But the range of ideas accretes together more naturally in a period used to the compendium approach that was part of daily education.

\section{Renaissance temperance through the lens of some primary sources}

\section{The compendium of cardinal virtues of Simon Harward}

An illuminating source for this study has been a 1596 Latin compendium of quotations, organised around the cardinal virtues, by Simon Harward, chaplain of New College. His Encheiridion Morale is a collection of quotations from Greek, Latin, French, Italian and Spanish writers and was intended for use as a text for translation by schoolboys (Harward 3-6). This compendium provides a fast route to erudition in knowledge of the cardinal virtues, and gives a sense of the way a range of ideas about temperance could easily have been seen as yoked together by those with even superficial claims to higher education, the more educated sections of Shakespeare's audience for example, or even Shakespeare himself. Such compendia provide insight into a conceptual organising principle that translates easily across to a play or allegory written to explore closely the nature of a particular virtue or vice.

Harward's categorisations in the section De Temperantia provide some contrasts and additions to the categories of temperance already canvassed in this introduction. This section aims to describe the functions and effects ("munera et effecta") of temperance. The first category concerns the internal appetites ira, odium, philautia, and cupiditas - and how they are to be brought under the control of reason (Harward 99). This is, then, not just the Aristotelian enkrateia or 
continentia, the control of the desire for pleasure, but also self-control over anger, hatred, self-love and desire more generally. The second category is "how in external matters, in games as in serious things, we can observe temperance". And third is "how we can avoid the obscene pleasures of the beasts both in mind and body, and how by contrast we can embrace the true delights of honest scholarship" (99).

Harward cites 'Il conte Baldassar' (Castiglione) describing reason overcome by appetite as a rudderless and anchorless vessel driven by the winds (come nave, percossa da troppo furioso impeto de venti (100)). An echo of this commonplace is seen in Phaedria's little rudderless vessel in Spenser. From Horace comes the idea that anger is a brief madness (ira furor brevis est (100)), demonstrated perhaps most clearly in Hamlet in the wrestling over Ophelia's grave. From Plato comes the argument that the greatest victory is victory over oneself (non alios sed semetipsum superare victoriarum omnium praecipua est (101). No-one conquered by anger (devictus ira (102)) can think properly, according to Menander. Two things most lead men to evildoing, according to Cicero: extravagance and greed (luxuries et avaritia (109). Horace provides a quotation that reminds us of the imagery of feculent waters in Spenser and of the watery death of Ophelia, but which is essentially about greed. "He who needs only what is necessary for the job won't drink water fouled with mud, and nor will he lose his life under the waves" (112).

The second category, of decorum in serious things and in play, is broken into a series of sub-categories. The first sub-category is: things not repugnant to nature (naturae non repugnantes). The second is "doing what is suitable" (facientes quae conveniunt) in youth and age, and in public and private lives. Two interesting quotations from Castiglione fall into the category of doing what is not contrary to nature. Both run counter to Stoic apatheia. "It is not necessary to do away with all emotions in order to stop them disturbing us excessively" (Non tolle affectus, $u t$ perturbatio possit / Auferri (115). That "would be like trying to prevent drunkenness by decreeing that no-one should ever drink". The other is that emotions rightly controlled give great help and strength to virtue. They provide hatred of wickedness and help for justice, and anger revives the strong man (fortem suscitat ira virum (116)). If you take away the emotions, the mind is like a ship stuck on a high sea without any wind (ventus ubi omnis abest (116)). In quotations about youth and age come variants in Italian, Spanish and French of an injunction to govern yourself well while you are young if you want to live into an old age (119). From Isocrates, Claudian and Menander come variants of the idea that the king must rule himself 
(Non e buon Re qui non regge se (121). From Castiglione comes an image, a variant of which helps explain Hamlet's punning on "sun" and "son"; "As in the sky the sun, moon and other stars show to the world as in a mirror a certain image of God, so on earth those princes who love and serve him show a much more living image of God, and they show the splendid light of his justice to the people, accompanied with a shadow of his divine reason and intellect" (123). From Zenodotus in Greek comes the quotation, "I hate the vile hypocrite with a lying heart, who is a friend in words but a bitter enemy in deeds". The treatment of hypocrisy in Hamlet belongs naturally, it seems, in a treatment of temperance.

The final category of quotations contrasts "bestial pleasure" with "the true delights of study". Hamlet and Horatio, the scholars, belong naturally in a treatment of temperance. The forms of intemperance to be avoided covered by the quotations are all condemned in some way in Hamlet. They include drinking, gaming, women, excessive eating (126). Moderation is a keynote for drinking, and a quotation from the second-century Greek philosopher Athenaeus rehearses this ancient theme: all those who drink moderately lift the pain from their hearts; whoever drinks immoderately fills his breast with vice (vitiis sua pectora replet 133). According to Phocyllus, virtue brings honour (decus) but love brings great disgrace (dedecus). According to Menander the wickedness of women is a sweet damnation to men. As with the emphasis on drinking there is a large section of such misogyny. Hesiod says trust women as you would an imposter (140), suggesting something of Hamlet's accusations of hypocrisy directed at Ophelia.

The work concludes with the contrasting power and virtue of study. This section includes a direct reference to sophrosyne in Euripides; temperance [to sophron] is everywhere a great virtue, and gives great glory to man (144). From Plutarch comes the little gem, "When the bow is stretched it breaks; the soul when it relaxes - this was the epitaph for Theophrastus, who died immediately after he stopped studying" (146). That Hamlet is prevented by his uncle from returning to his studies in Wittenberg must, in these terms, lead to trouble. From Isocrates comes: "Work is good for the body, philosophy for the soul".

Perhaps most significantly for this study, the section on temperance ends with a brief group of memento mori quotations, again casting helpful light on why the episode of Spenser's Maleger and Hamlet's discussion over Ophelia's grave belong in the category of temperance. From Cicero comes the idea that nature gives us an inn to stop at but not to live in ((150). From Pindar: If anyone is rich and handsome 
and shows he is first in contests of strength, he should remember that nevertheless he carries mortal limbs and that the end of all is to go beneath the earth (150). The end of Hamlet exemplifies the point. Hamlet wins the physical test of the fencing, only to die.

Such tracts make it difficult not to see Hamlet as a dramatised compendium of temperance, as if Shakespeare is methodically and at times in a contrived and pedantic way pulling out all the stops that will make the concept reverberate in the play with an educated audience used to this kind of grouping of allied ideas. Rosencrantz, Guildenstern and Hamlet's wordplay about living "in the middle" (2.2.206) of fortune's favours is just such a joke. In treating temperance, both Spenser and Shakespeare were devising elaborate variations on what were, for their readers and audiences, well-established themes.

\section{Sir Thomas Elyot's The Governor}

The book of moral education was another popular source of knowledge about the cardinal virtues in the period. Sir Thomas Elyot's The Governor is probably the bestknown Tudor example of the genre. Elyot combines the Aristotelian system of virtues with the cardinal virtues of Plato, the Stoics and Aquinas. Temperance, "a sad and discreet governess, awaiting diligently, that in any wise voluptuousness or concupiscence have no pre-eminence in the soul of man" (209), is presented in the narrow form of the Aristotelian control of sensual pleasures in the section of the book on temperance. But Elyot also deals with wider uses of temperance in other places. He has a Platonic view of the tripartite nature of the soul, in which reason is brought into harmony with the spirited element by the education of the mind and body, and from this point can command the appetites. Injustice in the soul leads to a form of civil strife among the three elements of this Platonic soul. Distemperance of the elements of the body leads to sickness of both body and mind. The general Aristotelian doctrine of the mean is also applied to all the virtues in the book. In politics, drawing heavily on Plato's Republic, temperance can be seen when the rulers and ruled live together harmoniously. The importance of everyone maintaining their place is important to this harmony.

In looking at temperance more narrowly, Elyot begins by making Aristotle's distinction between temperance and continence, the one a virtue of habit and the other of necessary repeated control (209; III.xx). Elyot also cites Plotinus in this discussion: "the wonderful philosopher" who "maketh an excellent definition of 
temperance, saying that the propriety or office thereof is to covet nothing which may be repented, also not to exceed the bounds of mediocrity, and to keep desire under the yoke of reason" (209; III.xx). Elyot also notes that "there be many other virtues which do seem to be as it were companions of temperance" (209; III.xx), and then chooses to address only two of these, moderation and soberness, essential for wisdom. He gives a series of examples of moderation in the rule of famous leaders. When we reach the example of the young Alexander, refusing titles unfitting for his years and also refusing to let his wife wear more expensive jewels than other ladies, we are now clearly in the domain of temperance as modesty (211; III.xxi). This includes moderation against wrath or appetite for vengeance. Thus a man who had offended Hadrian in his private life was dismissed with "thou hast well escaped", because Hadrian would not pursue private vengeance in his public capacity when he was emperor (211; III.xxi).

Elyot's book then moves on to "the ancient temperance and moderation in diet, called sobriety or, in a more general term, frugality" (213; III.xxii). Augustus set his people a proper example of moderate feasting in a time of famine. But at the opposite extreme, "in a nobleman much pinching and niggardship of meat and drink is to be discommended" (215; III.xxii), and we see the sentiment of Hamlet's ironic statement: "Thrift, thrift, Horatio. The funeral baked meats / Did coldly furnish forth the marriage table" (1.2.180-1). A series of excessive and picky feasters are then admonished, including Cleopatra's dissolving of her pearl earring in vinegar (217; III.xxii). Claudius's similar act in Hamlet recalls an iconic example of excess.

\section{George Turberville's translation of Dominic Mancinus}

Dominicus Mancinus, a $15^{\text {th }}$-century neo-Latin poet, wrote a work on the four virtues, De Quatuor Virtutibus, which became standard fare in the English grammar schools of the $16^{\text {th }}$ century (Baldwin 642-3). I cite here George Turberville's wonderfully rollicking 1568 Elizabethan translation, but Spenser and Shakespeare are likely to have read the Latin original. Temperance, in this work, takes its place as the last virtue in the Stoic hierarchy for which the order is: Prudence, Justice, Fortitude and Temperance. Stoic decorum is the keynote of the section on temperance. "He temperate may well be termde / and calde a modest man / That bridle motions of the mynde / with Reasons snaffle can: / And keepe Decorum in his words, / and eke in erye deede" (1.1505-10). The temperate man should pursue the good alone, making do with the simple things nature requires, and avoid pride and 
ambition. The self is sufficient and this is the basis of self-knowledge: "The man that owes and hath himself / not many things doth misse: / He deemes he hath suffising store / that hath hymselfe ywisse" (1.1521-4). The opposite of such self-sufficiency is avarice: "But he that deemes his own too scant, / and seekes for foraine stuffe, / A misers life doth euer leade / and neuer hath ynuffe" (1.1533-6), including a yearning for all the things he does not have. Like a maimed man, "[e]uen so the wight whose inward mind / and wits are woxen dimme, / And can not see what Reason wills / for Errours foggie cloude, / Is compted not to have himselfe, / nor for a man allowde" (1555-60).

The injunction is clearly to self- knowledge: "Wherefore at first possesse thy selfe..." (1561), and to respond quickly to any disorder of the soul: "Then why if any griping griefe / thy sense and soule possesse / Seekst not with care to cure the same / and quickly to redresse?" (1589-92). The solution is to cure the mind: "Wherefore especially thou must / the sicknesse of the soule / Remoue, that nothing want, and that / thou mayst be perfect whole" (1633-6). What properly belongs to the soul and mind is " $[\mathrm{t}]$ o hope for that alone which still / is sure to bee a stay / And such a great surpassing good / as neuer will decay" (1645-8). You need to avoid the things that will lead to harm, and so the flames of eternal exile. "Those passe into their countrey, [i.e. heaven] that / by meane of wittie braine / And Reason, ridde themselves of yll, / and did the Good attaine" (1689-92). We then have a version of Ovid's maxim, "I see and approve the good and pursue the bad": "The Minde doth rouing runne astray, / as often times as it / Not gouernes, and doth see the good, / but followes not a whit" (1697-1700). Temperance is called "a Motion of the Minde" (1706).

Having both established temperance in terms of calm and health of the soul, and a Christian threat of hell-fire for the intemperate, Mancinus then moves to Cicero's modesty and decorum. Honesty, which guides the motions of the mind and covers the body like another skin, consists in habit, gesture, measure of voice, "bashfull blushing hue" (1761), and "robes, time, and seemely place" (1762). It is important not to disdain the world's opinion of your behaviour. Decorum is not just of the body but also of the mind. "It is an easie thing the Minde / to frame and fashion fit, / As long as Reason rules the rost, / and in her seat doth sit. / Or (though by happe she be displaste / a litle) if she get / Hir olde and sacred roome againe / and raigne deuoide of let" (1791-8). The recipe for this state of rational control follows. This is firstly refraining from anger, and secondly from too much delight in dalliance and play. Too much laughter makes boys look like "gigling dames that Reason want / 
and haue but slender witte" (1929-30). While play is dangerous, especially for young men, exercise is acceptable in moderation. It's good to vary study with conversation with the learned (1955-58).

Mancinus then moves to the sub-category of temperance, continence, the bridling of "Venus part," (1961-2) and avoiding over-eating and drinking. If you do fall, you need to fight back quickly, because "[a]s God is farre from fleshe, so thou / from fleshe must farre decline" (2029-30). Even if "thou in secrete do offence / and no man see thy face," the conscience knows the lust of the flesh (2031-34). In this and all things, age should guide youth, and youth should do reverence to the aged. Old men should also avoid lust and boys should be taught to do their lessons (204850 ), even though the fruits of them may not be apparent for years.

There is then an injunction to modesty in dress: "For feare thy outwarde garment doe / thine inwarde kinde bewray. / For sundry nice vnmanly men / by nice attire are spid /...For sure it is a filthie thing / a man to be too nice" (2121-42). But this should not go too far: "Yet let thy garments handsom bee / not sluttish..." (21512), and the mean is appealed to: "Keepe thou amid the two extremes" (2155). The same applies to diet (2169-90). Observing and finding your right place in life is also covered at some length, not being over-mild and not being altogether without ambition.

Mancinus then shifts to a Stoic concern with decorum in speech. He cautions to avoid flatterers (2779-87). On the other hand, you should not boast but you can modestly establish proper praise of yourself (2875-8). In Christian terms, wanting glory is vain: "It is not wee, but CHRIST, our King / that doth atchieve the same" (2893-4). Mancinus then returns to decorum, to the tactful admonishing of friends and then to means in types of housing and other such issues, familiar from Cicero's De Officiis.

\section{Calvin's rules for "The Life of the Christian Man"}

A Protestant version of Cicero and Aquinas' rules for temperate behaviour is provided in Chapters VI-X of Book III of Calvin's Institutes of the Christian Religion. These five books amount to a little enchiridion for Christian behaviour, a smaller version of the work on Christian living compiled by Erasmus. They amount to a definitive statement of the nature of Calvinist temperance, and as such, I believe, provide an important key to the spirit in which Spenser adopts temperance as the second topic of his allegorical poem to follow holiness. 
Calvin clusters Chapters VI-X of Book III of the Institutes together in his introduction to Chapter VI, under the heading "The Life of the Christian Man" (Vol 2, 1). While Chapter X contains content that is most naturally identified with temperance (as seen for example in the cited work of Harward, Elyot and Mancinus) as a guide to daily life, the other chapters provide the context for applying temperance in a specifically Christian and Protestant way. To be temperate as a Christian in the Institutes requires an understanding of Christ as the model of life; of the Scriptures as the path to this model; of the need for Pauline self-denial and humility; of the relationship of self-denial and charity to others; of the difference between the patience resulting from total dependence on the Cross and Stoic apatheia; and of the need to temper the weariness of this life with Pauline hope in future salvation. After understanding these Christian principles, other more classical approaches of temperance to daily behaviour can be applied.

First, Calvin argues strongly in Chapter VI for the Scripture and the model of Christ as the right source of moral guidance (an argument which will be returned to through patristic sources in Chapter Eight of this study):

Come, then, and let them show me a more excellent system among philosophers, who think that they only have a moral philosophy duly and orderly arranged. They, when they would give excellent exhortations to virtue, can only tell us to live agreeably to nature. Scripture derives its exhortations from the true source...Christ, through whom we have returned to favour with God, is set before us as a model, the image of which our lives should express. (2,3; III.vi. 3)

A key Biblical quotation for temperance, Romans 3.4, and the need to be conformed to Christ, is cited in support, and this is contrasted to the reference to the nature of classical moral philosophy. Instead, those ingrafted into the body of Christ through baptism "should anxiously beware of contracting any stain or taint" (2, 4; III.vi.3). And no-one "truly has learned Christ who has not put off "the old man, which is corrupt according to the deceitful lusts, and put on Christ' (Eph.4.22)" (2, 4; III.vi.4). Calvin, in line with Augustine, makes a pivotal statement supporting the heart over the intellect.

Doctrine is not an affair of the tongue, but of the life; is not apprehended by the intellect and memory merely, like other branches of learning; but is received only when it possesses the whole soul, and finds its seat and habitation in the inmost recesses of the heart. (2, 4; III.vi.4)

Calvin emphasises the difficulty of achieving proper Christian moral virtue, but this should not prevent the attempt. "No one will travel so badly as not daily to 
make some degree of progress. This, therefore, let us never cease to do, that we may daily advance in the way of the Lord; and let us not despair because of the slender measure of success" (2, 5; III.vi.5).

Chapter VII brings us even closer to temperance as a summary of the Christian life; it is related to self-denial and contains a series of Biblical quotations that should also be seen as central to Christian temperance as it is portrayed by Spenser. The first is Romans 12.1, which says it is the duty of believers to present their bodies "as a living sacrifice, holy and acceptable to God, which is their reasonable service" (qtd 2, 7; III.viii.1). And so there is the Pauline exhortation, so important to Augustine's treatment of temperance: "Be not conformed to this world: but be ye transformed by the renewing of your mind, that ye may prove what is that good, and acceptable, and perfect will of God" (qtd 2, 7; III.viii.1). Believers should live and die to Christ (as in Romans 14. 8). Pauline spiritual renewal, the renewing of the mind, "that by which the mind, divested of its own carnal feelings, implicitly obeys the call of the Spirit of God" $(2,7 ;$ III.viii.1) was unknown to the philosophers, Calvin argues, and this is why they believed reason alone could be listened to. "But Christian philosophy bids her [reason] give place, and yield complete submission to the Holy Spirit, so that the man himself no longer lives, but Christ lives and reigns in him (Gal. ii. 20)"(2, 7; III.viii.1).

While self-denial should not be avoided, it should not be indulged in from a sense of pride. The fault of the philosophers is in following virtue for the sake of praise (2, 8; III.vii.2). After God's grace removes ungodliness and worldly lusts, the action of human lives is reduced to three branches, sobriety, righteousness and godliness, and with sobriety we are clearly in the conceptual envelope of temperance. "Sobriety undoubtedly denotes as well chastity and temperance as the pure and frugal use of temporal goods, and patient endurance of want" (2, 9; III.vii.3). Avoiding self-love becomes the source of moderate behaviour towards others. "The only way by which you can ever attain to true meekness, is to have your heart imbued with a humble opinion of yourself and respect for others" (2,10; III.vii.4). Calvin makes a list of possible calamities, sickness, mildewed crops, family members carried off by disease and so on: "[W]hatever happens, knowing that it is ordered by the Lord, he will receive it with a placid and grateful mind, and will not contumaciously resist the government of him, at whose disposal he has placed himself and all that he has" (2, 15; III.vii.9). In this way, pious minds achieve something which again sounds like that calm of temperance, "tranquillity and endurance" (2, 14, III.vii.10). Above all the Christian will not attribute adversity to fortune, as the pagans do (2, 15; III.vii.10). 
Chapter VIII, on bearing the cross as a form of self-denial, describes the necessity of the constant reminder of human frailty, so that we do not "estimate our virtue against its proper worth", and directly attacks Stoic philosophy. The solace of the cross should lead to not only patient but also cheerful endurance, an endurance devoid of expressions of excess.

Were there no hardship in poverty, no pain in disease, no sting in ignominy, no fear in death, where would be the fortitude and moderation in enduring them? But while every one of these, by its inherent bitterness, naturally vexes the mind, the believer in this displays his fortitude, that though fully sensible of the bitterness, and labouring grievously, he still withstands and struggles boldly; in this displays his patience, that though sharply stung, he is however curbed by the fear of God from breaking forth into any excess; in this displays his alacrity, that though pressed with sorrow and sadness, he rests satisfied with spiritual consolation from God. (2, 21; III.viii.8)

This Christian position is then contrasted to Stoicism.

You see that to bear the cross patiently is not to have your feelings altogether blunted, and to be absolutely insensible to pain, according to the absurd description which the Stoics of old gave of their hero as one who, divested of humanity, was affected in the same way by adversity and prosperity, grief and joy; or rather, like a stone, was not affected by anything. (2, 21; III.viii.9)

Calvin, in an often-cited rebuttal of Stoicism, replaces its "iron philosophy" with the example of Christ's weeping (22; III.viii.9). Acceptance of the justice of the cross leads to the need to "temper" its bitterness with spiritual joy.

Chapter IX establishes a dichotomy between the present and future that is strongly Augustinian and is used by Spenser in the Cave of Mammon episode. Calvin presents it as intemperate, in a Christian sense, to place the goods of the present above the future life, but this is what people do.

Hence our stupidity; our minds being so dazzled with the glare of wealth, power, and honours, that they can see no farther. The heart also, engrossed with avarice, ambition, and lust, is weighed down and cannot rise above them. In short, the whole soul, ensnared by the allurements of the flesh, seeks its happiness on the earth. (2, 25; III ix.1)

The dichotomy is absolute: "For there is no medium between the two things: the earth must either be worthless in our estimation, or keep us enslaved by an intemperate love of it" $(2,26$; III.ix.2). The present life, particularly in Calvin's French, sounds very like the witchcraft of Spenser's seductive Bower of Bliss: "pource que la vie presente a tousiours force de delices pour nous attraire, et a grand apparance d'amenite, de grace et de douceur pour nous amieller, ils nous est bien 
mestier d'estre retire d'heure en d'heure, a ce que nous ne soyons point abusez, et comme ensorcelez de telles flatteries [my emphasis]" (2, 26; II.ix.1).

Calvin then compares classical contemplation on death with Christian comfort. "If we see a funeral, or walk among graves, as the image of death is then present to the eye, I admit we philosophise admirably on the vanity of life...But, at the best, our philosophy is momentary" (2, 26-7; III.ix.2). While constant reminders of the miseries of this life are essential, Calvin allows that the present life does acquaint us with the goodness of God and so should not be despised on this account. As the improper love of this life diminishes, the desire for a better life increases, and with this, the fear of death decreases. For the Christian, death and so "the advent of the Lord" will be "the most propitious of all events" (2, 30; III.ix.5). The Christian is not afraid of death, but looks forward "with joy to the day of death and final resurrection" (2, 29; III.ix.5). Even more strongly, "the whole body of the faithful, so long as they live on the earth, must be like sheep for the slaughter, in order that they may be conformed to Christ their head" (30; III.ix.6). It is this attitude of mind that enables the Christian to renounce the intemperance of the world (30; III.ix.6).

Following this theological framework, Chapter X, "How to use the present life, and the comforts of it," could easily have been called "Of Temperance." Calvin gives a version of the mean: "[I]f we are to live, we must use the necessary supports of life; nor can we even shun those things which seem more subservient to delight than necessity. We must therefore observe a mean, that we may use them with a pure conscience, whether for necessity or for pleasure" $(2,31$; III.x.1). Although life is a pilgrimage to the heavenly kingdom, and Paul admonishes the faithful to use the world without abusing it, the world is a "slippery place", and our feet must be planted securely. But this does not mean going to ascetic extremes (presumably of monasticism).

There have been some good and holy men who, when they saw intemperance and luxury perpetually carried to excess, if not strictly curbed, and were desirous to correct so pernicious an evil, imagined that there was no other method than to allow man to use corporeal goods only in so far as they were necessaries: a counsel pious indeed, but unnecessarily austere; for it does the very dangerous thing of binding consciences in closer fetters than those in which they are bound by the word of God. Moreover, necessity, according to them, was abstinence from everything which could be wanted, so that they held it scarcely lawful to make any addition to bread and water. (31-2; III.x.1)

Calvin explicitly does not go as far as the type of philosophy later to be expounded by Hume, but clearly describes the shift to conscience over prescription. He does not mean that 
liberty is not to be restrained by any modification, but that it is to be left to every man's conscience to use them [the goods of this world] as far as he thinks lawful...Scripture having laid down general rules for the legitimate use, we should keep within the limits that they prescribe $(2,32$; III.x.1).

Calvin then establishes the following precept as in accordance with Scripture: "Let this be our principle, that we err not in the use of the gifts of Providence when we refer them to the end for which their author made and destined them, since he created them for our good, and not for our destruction" $(2,32$; III.x.2). This then is the Calvinist rule for temperance. The beneficence of God is not designed in the beauties of nature to be responded to as if man was a block. But conversely, gratitude to God for his gifts is not shown (and I list here examples given separately) "if you so gorge or stupefy yourself with feasting and wine as to be unfit for offices of piety, or the duty of your calling"; "if the flesh, boiling forth in lust through excessive indulgence, infects the mind with its impurity, so as to lose the discernment of honour and rectitude"; "if on account of sumptuous raiment we both admire ourselves and disdain others," "if, from a love of show and splendour, we pave the way for immodesty"; " if the glare of these things captivates the minds" (2, 33; II.x.3). These parallel the injunctions of the later Elizabethan homilies.

The Christian should avoid all excess:

He who makes it his rule to use this world as if he used it not, not only cuts off all gluttony in regard to meat and drink, and all effeminacy, ambition, pride, excessive show, and austerity, in regard to his table, his house, and his clothes, but removes every care and affection which might withdraw or hinder him from aspiring to the heavenly life, and cultivating the interest of his soul. (2, 33; III.x.4)

The final section of the chapter is against ambition, and enjoins acceptance of proper limits in the callings of life. "Every man's mode of life, therefore, is a kind of station assigned him by the Lord, that he may not always be driven about at random. So necessary is this distinction, that all our actions are thereby estimated in his sight, and often in a very different way from that in which human reason or philosophy would estimate them" $(2,34$; III.x.6). Calvin then makes the pronouncement so significant to Hamlet: "There is no more illustrious deed even among philosophers than to free one's country from tyranny, and yet the private individual who stabs the tyrant is openly condemned by the voice of the heavenly Judge" (2, 34-5; III.x.6). Finally Platonic conservatism is paired with a Christian rationale, "[e]very one in his particular mode of life will, without repining, suffer its inconveniences, cares, uneasiness, and anxiety, persuaded that God has laid on the burden" (2, 35; III.x.6). 


\title{
Chapter Three: Excess and self-knowledge
}

\author{
Pursue the good, and long for that, \\ and let alone the rest. \\ Those things are good that simple kind \\ and Nature doe require, \\ Not that wherto Ambicious mind \\ and Pride would faine aspire. \\ The man that ow[n]es and hath himself, \\ not many things doth misse: \\ He deemes he hath suffising store \\ that hath himselfe ywisse.
}

(Mancinus, 1515-1524).

As argued in the introduction, the virtue of temperance in Spenser and Shakespeare's period is contained in a flexible but firm and resilient conceptual envelope. This chapter will explore the extent to which both FQII and Hamlet retain the preoccupations that surround the early Greek uses of sophrosyne. It will also, looking particularly closely at Claudius's failed repentance speech and at Hamlet's encounter with Gertrude in her chamber, and using Euripides' Hippolytus as a model, develop a reading of Hamlet as a play about conflicting aspects of temperance and intemperance.

The roots of temperance go back beyond the Greek polis to Hesiod and the Seven Wise Men. The virtue is given voice in the combination of Delphic maxims: "Know thyself," and "Nothing in excess," (North 5, 9) displayed on the temple of Apollo at Delphi (as any self-respecting tour guide tells modern tourists to Delphi), and the associated maxim "Think Mortal Thoughts." The three precepts interact naturally, and their combination must be seen as in some sense essential to both Greek thought and the Western intellectual tradition which builds on it. To go to excess involves a lack of respect for the limits imposed by the gods and so involves a lack of understanding, of self-knowledge, of the limitations of being human.

Sophrosyne as a term in general usage, and as a concept in literature, philosophical and political writing, came into particular prominence at the time of the polis, in part because it countered the individualism of the heroic. It provided stability and safety following a period of rapidly alternating success and disaster (North 150). In this sense it was a political virtue, used at different times by the 
aristocracy and by the emergent middle class. In epitaphs of the seventh century, military prowess is balanced with patriotic duty in times of peace, the physical is balanced with the intellectual, and for this variants of sophrosyne are used. It becomes an antonym for hybris, which itself becomes an attribute of tyrants, and so sophrosyne is the virtue of constitutional government. In the poetry of the sixth and early fifth centuries, two early senses of the word sophrosyne, prudence and soundness of mind, start to develop moral and religious connotations (North 16). Sophrosyne also becomes a civic virtue, as it will later be as a cardinal virtue. From early times it is associated particularly with the young, although also the hard-won self-control of old age. It is associated with sobriety, restraint and abstinence and is a virtue with particular application to both unmarried and married woman (including with it the characteristics of thrift and management, chastity, quietness in the home and not being noticeably in public more than necessary) (North 21).

More intellectually, Heraclitus directly links sophrosyne and self-knowledge. "Sophronein is the greatest Arete, and wisdom (sophia) consists in speaking the truth and acting in accordance with nature, paying heed to it" (North 26). Helen North gives us the following commentary, which may stand as a sort of bench-mark for all discussion of self-knowledge that follows.

...by self-knowledge Heraclitus seems to mean a searching examination into the soul to discover the universal law common to man and the cosmos. If he connects sophrosyne with this deep and essential self-knowledge, there should be nothing startling about the statement that sophronein is the greatest arete. It is another name for the faculty by which man may attain that wisdom whose object is the universal logos. Through this process man comes to know the law that governs his own soul and the rest of the universe. (27)

This teleological aspect of temperance, and its importance as a precondition of wisdom, present from the early days of sophrosyne, is essential to the study to follow, and easy to lose sight of once the discussion shifts to moral behaviour and the control of the passions.

\section{Self-knowledge and sophrosyne in the Charmides}

In Plato's Charmides, an early and hence very Socratic dialogue, the senses of sophrosyne that belong to the Delphic code and the Dorian system of ethics are examined and discarded in the search for a deeper and more intellectual understanding. It is useful to discuss this dialogue at this point, because it both gives a glimpse of some popular views of sophrosyne by the time of Socrates and as seen 
in the work of the great Greek writers of tragedy, and the beginnings of the search for a more philosophical interpretation of the virtue. Helen North comments that Plato exposes "as superficial the most widely accepted traditional definitions of sophrosyne and employs characterization in such a way as to leave an impression of the difference between false and true, superficial and profound sophrosyne, more lasting than the memory of any mere process of argumentation" (158). I would like to draw attention to this sense of a hierarchy of meanings of sophrosyne as an important one, one which can also be applied to Spenser and Shakespeare's treatment of temperance.

Charmides, a physically beautiful and blushing young man who shows the natural modesty we see in the encounter of Spenser's Guyon's with Shamefastnesse in the House of Alma, is examined by Socrates with his uncle Critias (Plato Charmides $13 ; 154 \mathrm{C})$. The setting of this dialogue in a palaestra foregrounds the relationship of health of body and health of mind that must also be associated with temperance (and is seen in Hamlet in the preparation for the fencing scene). The dialogue is also underpinned by knowledge of the future death of Socrates and of Critias' later role as leader of the Thirty Tyrants, and of Charmides' death in the oligarchs' brutal revolution (Charmides, introduction, 4). Socrates (himself identified with sophrosyne in a range of ways) demonstrates the ethos of sophrosyne in the dialogue, as he directs his eros to the intellect of Charmides and not his physical beauty $(13 ; 154 \mathrm{E})$. The moral sense of sophrosyne as self-control is established first. Charmides represents a natural sophrosyne, the self-restraint of some animals and children, which however it is not possible for them to explain. Socrates by contrast represents sophrosyne as an inner philosophical virtue.

Socrates begins by arguing that Charmides' headache cannot be cured without curing the whole body $(19 ; 156 \mathrm{C})$, making explicit the link between health of body and health of mind. The dialogue moves from outer to inner and from popular morality to intellectual analysis. Socrates' initial aim is to prove to Charmides that his knowledge of sophrosyne is mistaken and limited. He rejects the popular ideas of sophrosyne as a kind of quietness in walking, talking and similar activities $(33 ; 160 \mathrm{C})$; as modesty $(35 ; 161 \mathrm{~B})$; as doing one's own work and attending to one's own affairs (a fundamentally aristocratic idea)(39; 162); as general utility and the Delphic command of self-knowledge: "practise sophrosyne," (49; 165) - all traditional definitions of sophrosyne. This dialogue in fact provides an important instance of the Delphic identification of self-knowledge and sophrosyne. Socrates 
then moves to more intellectual elements. Sophrosyne is knowledge of itself (gnothi sauton), knowledge of other sciences $(51 ; 165 \mathrm{C})$, knowledge that one knows and does not know, and knowledge of what one knows and does not know $(55 ; 167)$. Critias reaches the conclusion that the knowledge that makes us happy is the knowledge of Good and Evil (83; 174B), and at this point the subject of the dialogue becomes the relationship of virtue and knowledge rather than sophrosyne itself as a virtue. Although Socrates rejects Critias' view that sophrosyne is not useful (85; 175B), the status of sophrosyne itself is left unresolved (85; 175D).

\section{Sophrosyne in Greek Tragedy}

In Greek tragedy we see enacted the conflict between the heroic individual and the world order that curtails heroic freedom. This order is expressed through the concept of sophrosyne. Each of the great tragic poets treats the conflict differently. For Aeschylus, sophrosyne is a strongly masculine virtue involving respect, first, for the limitations imposed by the gods, and then those imposed by society. "Aeschylus associates sophrosyne with a set of key ideas - freedom, justice, defence against aggression, masculinity, Hellenism - to which he opposes a set of antitheses tyranny, injustice, aggression, femininity, barbarism, and above all hybris" (North 33). Not overstepping limits, especially those set by the gods, and so not failing to "think mortal thoughts", is at the heart of Aeschylean sophrosyne. The forces opposed to good in Aeschylus' plays are often seen in terms of an ambitious and arrogant barbarism that threatens moderate and reasonable values. Different senses of sophrosyne are at work at different places within the plays. The Danaids in the Suppliants are chaste, in the sense of naturally temperate as seen in Plato's Charmides, but they fail to be modest, calm and self-controlled in their defence of this chastity. Two different aspects of sophrosyne, chastity and self-control, are thus put in direct conflict with each other in the play; this causes a wider failure of sophrosyne as moderation and balance, leading to ultimately tragic consequences.

At the conclusion of the Oresteia, sophrosyne (moderation) is explicitly seen as a defining characteristic of Athens, and "emerges as the force that will save the polis from the two extremes of anarchy and despotism" (45). Apart from the barbarity of the foes that oppose such moderation in Aeschylus, and his disdain for irrational emotional display by women, the moment of most relevance to my study may be the hybris in Agamemnon's decision to step onto the blood-red carpet in the Agamemnon. Agamemnon makes this choice knowingly; he is aware that to step on 
the carpets laid out as a welcome by Clytemnestra is to challenge the gods and to literally trample on sophrosyne. First he attempts to reject this attention:

For the rest, pamper me not after woman's wise, nor, like some barbarian, grovel to me with wide-mouthed acclaim; and draw not down envy upon my path by strewing it with tapestries. 'Tis the gods we must honour thus; but for a mortal to tread upon broidered fineries is, to my judgement, not without ground for dread. I bid thee revere me not as a god, but as a man. Foot mats and broderies sound diverse in the voice of Rumour; to think no folly is Heaven's best gift. Only when man's life comes to its end in prosperity dare we pronounce him happy. (Aeschylus 77; 918-929)

When Agamemnon reverses this decision, it then amounts to a very clear-sighted rejection of sophrosyne and the injunction to "think mortal thoughts", and his subsequent murder becomes a natural consequence of the choice: "As I tread upon these purple vestments may I not be smitten from afar by any glance of Heaven's jealous eye" (81; 946-7). The choral odes in the Agamemnon link sophrosyne with pathei mathos, learning through suffering, and what is learned is sophrosyne (North $45)$.

In Sophocles it is the individual and their failures of sophrosyne, rather than a conflict between sophrosyne and hybris, that characterises the presentation of the virtue. For Sophocles, sophrosyne is associated with self-knowledge and the power to recognise reality. What opposes sophrosyne is when "heroic self-assertion is carried to an extreme" (North 32). The central figure in a Sophoclean play "encounters disaster through a weakness that is inextricably connected with his strength" (North 51). He or she is also prone to delusion, the failure of selfknowledge that goes back to the etymological "soundness of mind" of sophrosyne. Helen North makes a particular point of describing the way sophrosyne can be seen as both a low-level and higher virtue in Sophocles, and this reinforces the sense of a virtue with different potential value already raised in the discussion of the Charmides. Thus some characters only display a habitual rather than philosophical virtue, one that "consists mainly in obedience to rulers and control of appetites" (54). She then establishes a hierarchy across the plays. Creon in Oedipus the King is on a second rung, one step higher than those employing an unthinking habitual virtue. "He abides by all the rules: he is cautious in assertions (569); he thinks mortal thoughts; he refuses to act without consulting the gods (1438-39); he prefers to enjoy untroubled the power of a king rather than to have at once the name and manifold troubles of a king (he calls this preference sophron [589]); and he refuses to gloat over the downfall of Oedipus, who has so brutally threatened him" (North 54-55). 
Odysseus in the Ajax is on the third rung of the ladder. His sophrosyne "is of an enlightened character, and unlike Creon, he is a thoroughly sympathetic character...generous and magnanimous" (North 55). But he lacks a heroic quality. “Only one of all Sophocles' sophrones foil characters may properly be called heroic: Theseus in the Oedipus at Colonus." Theseus welcomes the outcast Oedipus to Athens and he uses the "commonplace of sophrosyne... 'I know I am mortal"" (North 55). His own demonstration of self-control makes it legitimate to urge selfcontrol on Oedipus. This sense of a sophrosyne as potentially a low level virtue of caution and safety, or in stages a more noble virtue of generosity grounded in selfknowledge, is significant for the works at stake in my study.

The Oedipus builds to a self-knowledge North describes as "the essence of Sophoclean sophrosyne...healing as well as wounding" (North 64). Oedipus' initial lack of self-control, his pride and irascibility in his encounter on the road with an old man, as reported in the play, is the source of his downfall.

Making my way toward this triple crossroad I began to see a herald, then a brace of colts Drawing a wagon, and mounted on the bench... a man, Just as you've described him, coming face-to-face, And the one in the lead and the old man himself Were about to thrust me off the road - brute force And the one shouldering me aside, the driver, I strike him in anger! - and the old man, watching me Coming up along his wheels - he brings down His prod, two prongs straight at my head! I paid him back with interest! Short work, by god - with one blow of the staff In this right hand I knock him out of his high seat, Roll him out of the wagon, sprawling headlong I killed them all - every mother's son! (Oedipus 884-898)

It is in Oedipus' slowness to see the application of the story of this encounter to himself, to see how central it was to his nature that wounded pride would lead to an immediate and excessive response of irascibility, that is his problem of selfknowledge.

Euripides' plays involve conflict between the rational and irrational, and so sophrosyne is seen more as a moral than an intellectual virtue, and the action is more 
psychological (North 69). Sophrosyne is also given a wider range of meaning by

Euripides. North distinguishes the three poets in the following way:

To Aeschylus, who found the source of tragedy in hybris, the arrogant transgression of the Divine and human law, sophrosyne was essentially religious, an acceptance of mortal limitations. To Sophocles, whose tragic concept was rooted in the imperfection of the heroic nature, sophrosyne was the self-knowledge that enables man to come to grips with reality. To Euripides, who saw in the triumph of the irrational over the rational the primary source of tragedy for the individual and society, sophrosyne is one of several names for the rational element. It is that quality, intellectual in origin, but predominately moral in its application and effect, which controls and moderates the passions, whether lust, anger, ambition, cruelty, or even something so trivial as gluttony or drunkenness. (69)

Sophrosyne in the Iphigenia in Aulis means moderation, sanity, chastity, modesty and good sense (69). North argues that Euripides' use of sophrosyne for aspects of self-control shows the influence of sophistic thought in the period, and that sophrosyne was popularly seen "as a kind of spoilsport which deprives life of all that makes it worth living" (70). In his dramas Euripides examines the downfall brought by wicked and passionate women, but also the sophron woman like Andromache, quiet and tactful (71). Euripides also develops, particularly in his choruses, the idea of sophron eros, love in moderation, without the extremes of passion, jealousy and violence (73). In Bacchae and Hippolytus, different meanings of sophrosyne are played off against each other. I propose to sketch more closely this interaction in the Hippolytus, because it shows the way a conflict of differing types of temperance might be taking place in Hamlet.

Hippolytus is sophron in the sense of sexually chaste. Such chastity is on the one hand a natural virtue of the type we have already seen with Charmides, and see with Spenser's Guyon - that of the blushing young man. But it is a virtue Hippolytus pursues with a passionate conviction which conflicts with meden agan and gothi sauton, moderation and self-knowledge (79). Phaedra, in pursuing Hippolytus, her step-son, demonstrates a contrary lack of natural chastity. She knows what is right, and the consequences for her reputation of pursuing her passion, but cannot combat it. The nurse uses a distorted and sophistic argument to say that it is a form of hybris on Phaedra's part to resist the power of eros, and so she should give in to it (81). When Phaedra does approach Hippolytus, his rejection of her is fanatical and cruel, lacking, in other words, in all temperance. This intemperance leads to Phaedra's revenge and suicide. Theseus then pursues an irrational impulse for revenge, 
demonstrating another form of intemperance as he responds to Hippolytus with anger and rash judgement.

Greek tragedy may not have been a direct source for either Spenser or Shakespeare, although the path from Euripides through Seneca to Shakespeare is reasonably direct. My purpose in this section has been to show some of the complexity of sophrosyne in the Greek period, and before its development as part of the great philosophical systems. It will probably now be clear in advance how these ideas can be applied to a reading of Hamlet as a play concerned with temperance, a reading I will attempt in the final section of this chapter. The application of these ideas is less immediately apparent in Spenser and raises more problems, and I will turn to this first.

\section{“Know Thyself” and "Nothing in Excess" in Spenser}

The Delphic injunction to "know thyself" is perhaps more commonly associated with prudence than temperance in the Renaissance period, as part of the conceptual narrowing of temperance discussed briefly in the introduction. Spenser, however, very clearly links the injunctions "know thyself" and "nothing in excess" when Guyon approaches the boundaries of the Bower of Bliss in FQII.xii. Guyon first encounters a porter called "Genius" (II.xii.47.i) who is not (to summarise the stanza) the celestial power to whom the care of life and generation pertains and who lets us see "wondrous things concerning our welfare" (II.xii.47.5) and "ofte of secret ill bids vs beware" (II.xii.47.7). He is not (in a charmingly tautological couplet) "our Selfe, whom though we do not see, / Yet each doth in him selfe it well perceive to be" (II.xii.47.8-9). In defeating this genius who is not "our Selfe", Guyon seems, in his own response, to be demonstrating the power of such a self in action. He can see through the (rather transparent) ruse that this genius represents as "Pleasures porter" (II.xii.48.8). Guyon's destruction of this porter's mazer bowl of wine, and the staff by which the porter "charmed semblants sly"(II.xii.48.8), suggests an ability to see through the false, allied to the self-knowledge evoked by the use of "Selfe." One way of seeing Guyon's response to the guardian of the Bower of Bliss is as a signal of Guyon's own self-knowledge, and so of resilience to temptations of pleasure acquired by Guyon in the previous cantos of $F Q \mathrm{II}$. Guyon then encounters a figure called Excesse, who sits under an overburdened arch of grapes and holds in her left hand a cup of wine, into which she squeezes grapes from an outstretched right hand. Guyon violently smashes this offered cup. 
This sequence is like tableau vivant versions of two figures from a book of emblems representing the Dephic injunctions "know thyself" and "nothing in excess", and it is the sequence of one following the other that suggests most strongly that it is these precepts that Spenser is invoking here. Guyon, knowing who he is, is enabled to identify and reject excess, and so behaves as a knight of temperance should. On the surface of things, however, his destructive response seems excessive, and establishes in little the larger sequence of the canto, with its cumulative destruction of the entire bower.

How to view the apparently intemperate destruction of the Bower of Bliss is of course one of the vexed topics of Spenser scholarship. Michael Schoenfeldt provides the following approach to this problem:

Although frequently defined as a middle ground between disagreeable opposites, temperance is continually driven to extremity by the situation in which it is enacted. The enforcement of temperance begins to demand forms of extreme violence that replicate the forces it intends to harness. The more ethical pressures Spenser puts on temperance over the course of the book, the more its maintenance requires intemperate action. This process reaches its apotheosis in the troubling destruction of the Bower of Bliss where we are made to experience Spenser's immense ambivalence about whether extremity in defence of the virtue of temperance is a vice. (44)

One way of approaching the conundrum of the excessive destruction of excess is the cross-cutting of types of temperance just surveyed in the conflicting types of sophrosyne in Euripides' Hippolytus. Temperance as control of the urge to pleasure requires strong and forceful action - something different from temperance as equitable, mild and moderate behaviour. Part of the seduction of the bower is its apparent mildness and equanimity, reflected, as we have seen, in the use of temperance as a word for mildness of climate. In the Bower of Bliss it is clear, however, even from the first artificiality of the grapes over Excesse's porch - "So made by art, to beautify the rest" (II.xii.55.2) - that it is appearance rather than reality that is at stake. The ability to distinguish the false from the true is being associated with self-knowledge from Guyon's first encounter with Pleasure's Porter at the entrance to the bower, and this association governs Guyon's final destructive responses. This does not in itself resolve the problem Schoenfeldt and others have raised for so long, but it gives it a slightly different shape. The issue is further complicated when we relate the injunctions "know thyself" and "nothing in excess", signalled so clearly by Spenser at the entrance to the Bower of Bliss with that other important Greek maxim, "think mortal thoughts", and realise that this is the focus of the centre of $F Q \mathrm{II}$. 
The Greek injunction, "think mortal thoughts", is signalled most strongly by the presence of Tantalus at the end of Guyon's passage through the Cave of Mammon. Tantalus' presumptuous desire to feast with the gods represents hybris in the sense of a challenge to the divinity, a direct refusal to accept mortal limitations. The classical injunction is then given a specifically Christian development when we find Pilate accompanying Tantalus. Pilate's hand-washing in the story of the crucifixion has all the features of apparent equitability and reasonableness, and in this sense parallels the apparent mildness of the Bower of Bliss. Underneath the veneer of reasonable governance, Pilate lacked the self-knowledge of (in Christian terms) the ultimate hybris. He thought he could judge divinity and so "Deliuered vp the Lord of life to dye" (II.vii.62.6). Spenser represents the deepest filth involved (on the model of a reverse ladder down to deepest intemperance) in Pilate's washing of his hands, a washing that in the Cave of Mammon becomes a washing in deepest feculence, to indicate the soiling of the soul with "fowle iniquity" (II.vii.62.9). Intemperance at the deepest geographical depth of Book II is, then, all about the failure to "think mortal thoughts," a form of failure of self-knowledge. That Pilate is found at this end-point of the journey through the Cave of Mammon then shapes our view of the initial descent into the cave, suggesting that the territory traversed by Guyon in the Cave is not just to do with a desire for worldly goods, but a deeper sense of cupiditas, associated with pride that is itself the source of The Fall. One of the consequences of cupiditas after the Fall was the loss of clear judgement, the natural moral prudence surveyed by Lynette Black and critical to self-knowledge. Avarice, an expression of excessive desire, the pride of the failure to "think mortal thoughts" and an accompanying lack of self-knowledge become differently but just as importantly interconnected in Christian thought as they have been in classical thought.

Spenser uses a strong allusion to Boethius' Consolation of Philosophy 2 Prosa 5 (Hamilton 215) to convey the source of human misery in a sense of an avaricious desire for more than is provided by nature. All three Delphic precepts are violated in the Fall, whether in the Christian sense or the more classical loss of the golden age. The injunction "nothing in excess" is clearly violated by excessive desire for things that are not strictly needed; and the injunction to "think mortal thoughts" is violated by the hybris that lies behind such a desire, the pride of wanting to be more like the gods, which Agamemnon displays in stepping on the red carpets. The failure of self-knowledge demonstrated at The Fall is the failure to recognise the deeper loss that follows from the apparent gains of excess. Spenser's Boethian allusion makes 
this excess the source of all the imagery of feculent filth in FQII (215). Guyon answers Mammon's initial temptation to wealth well:

Indeed (quoth he) through fowle intemperaunce,

Frayle men are oft captiu'd to couetise:

But would they thinke, with how small allowaunce

Vntroubled Nature doth her selfe suffise,

Such superfluities they would despise,

Which with sad cares empeach our natiue ioyes:

At the well head the purest streams arise:

But mucky filth his branching armes annoyes,

And with vncomely weedes the gentle waue accloyes. (II.vii.15.1-9)

As Spenser echoes Boethius in Guyon's response to Mammon, we are left free to read the sentiments in terms of a pagan or Christian frame, as we are with Boethius. The dwellers in the antique world thought the equivalent of "mortal thoughts." They found no defect in the Creator's grace, but accepted the gifts of "soueraine bounty" (II.vii.16.4) with thanks and truth. It was pride, "like corn-fed steed" (II.vii.16.6) that led men to abandon a life that was "like Angels" (II.vii.16.5), and to "exceed the measure of her meane, and naturall first need" (II.vii.16.8-9) - in other words, to fail the injunction "nothing in excess." This led to the "sacriledge" (II.vii.17.4) of wounding the womb and tomb of man's great Grandmother, the earth, seeking for gold and silver from avarice and "pompous pride" (II.vii.17.7).

When Guyon, then, subsequent to this Boethian argument, refuses Mammon's offer of wealth until he has seen it is not tainted by some kind of bloodguiltiness, and Mammon responds that the goods have been kept safe from "heuens sight" (II.vii.19.9), it is hard not to see Guyon as guilty of a similar lack of selfknowledge to that of Oedipus, of failing to see that the case clearly before him also applies to him. Or, more seriously, to see his entry as the wilful act of an Agamemnon, who knows that stepping on purple carpets is a challenge to the gods but does so anyway. If it was an act of pride to seek for gold and silver in the earth in antique times, Guyon will not be exempt from a search for a commodity that is intrinsically blood-guilty (in the sense of being torn from the womb of the earth) to meet ends already described by Guyon himself as unnecessary. Once in the cave, Guyon's situation becomes morally complicated. He seems to show self-knowledge in never actually accepting the offered wealth, in being aware that if he does so he will be torn to pieces, and so seems to be being protected by the self-knowledge of 
the good genius "that oft of secret ill bids us beware" (II.xii.47.7). But this temperance of resistance disguises a deeper pride, that of thinking that, as the titular knight of temperance, the exemplar of moderate and reasonable behaviour, he is exempt from the consequences of The Fall, a hybris in some ways similar to Oedipus' inability to recognise the implications of the stories brought to him by the messengers of the play, or Pilate's failure to recognise the Lord of life when he stood before him. Anne Lake Prescott, in her article on the Cave of Mammon in The Spenser Encyclopaedia, also highlights Guyon's presumption in Christian terms in reprimanding Tantalus as if he himself was free from sin, and this reprimanding act leads us naturally to the hand-washing Pilate, as though Guyon too can wash his hands of the problem of innate sinfulness and the excessive desire that goes hand in hand with the failure to "think mortal thoughts" (452). Guyon's own fall at the end of the sequence of the journey through the Cave of Mammon then indicates the need for a deeper self-knowledge, a higher form of temperance. This higher form of temperance is the teleological one seen at the beginning of this chapter in Heraclitus, the relationship of self-knowledge to the governance of the whole universe and the individual soul, or in Christian terms knowledge of God and in Protestant terms knowledge of innate human sinfulness. Guyon, in Christian terms, requires the divine intervention of grace to establish such self-knowledge, and so collapses.

\section{Conflicting types of temperance in Hamlet}

A strong consequence of seeing Hamlet as a play thematically concerned with temperance is to see characterisation in terms of different aspects of temperance. As Othello and Iago convey different aspects and types of jealousy, Claudius and Hamlet can be seen to demonstrate different aspects of intemperance (in a similar way to the different failures of sophrosyne conveyed in Euripides' Hippolytus) and different attempts to control intemperance. The effect in turn of this approach is to bring Claudius more strongly into the centre of the play and to increase a sense of his status as a tragic character.

Claudius may be seen as a sort of walking version of Spenser's Bower of Bliss. He is overtly associated with excess at different points of the play. In the centre of the play, his covetousness for both his brother's crown and his brother's wife wins out against the eternal soul that could be regained through repentance. His excessive desires cost him his soul, an act seen allegorically in Spenser as Acrasia sucks out the soul of Verdant in the heart of the Bower of Bliss. Like Acrasia's 
Bower, Claudius is characterised by his artifice, an artifice of which we are aware, and by which we are still in part seduced. Spenser uses the metaphor of art for his Bower; Shakespeare's Claudius is revealed through the contrived and seductive artifice of oratory. Even after his speech confessing his murder and his failure to find a path to repentance, Claudius retains his appearance of reasonableness, and this reasonableness muffles our response to the extent of his crime.

Claudius can be seen from the opening of the play in terms of a hybris like that in an Aeschylean play. He promises as he leaves the stage in Act One Scene Two to celebrate his "accord" (1.2.123) with Hamlet by firing off a volley of cannon each time he drinks. It is an act that implicitly challenges Jove the thunderer. With the King's rouse, "the heaven shall bruit again, / Respeaking earthly thunder" (1.2.127-8). He thus associates himself with excessive drinking, the barbarity of which is spelt out by Hamlet in his speech against the national reputation for drunkenness (1.4.15-16). We are in a kingdom that, through attention to one of the common aspects of intemperance (as seen in the introduction), is characterised by its intemperance. The intemperance of the kingdom is not new and has not been established by Claudius, who in one sense merely continues its traditions. Hamlet's father also showed hybris of an Aeschylean kind in his challenging of old Fortinbras to single combat, a clash of Titans over national covetousness for land that establishes the pattern of adversarial clashes for the play. Old Hamlet also dies "full of bread" (3.3.80), so that Danish drunkenness is tied to Danish gluttony. The strongest image of excess, of a very Roman luxury in the play, is similar to that of Spenser's Excesse. We have already noted that when Claudius dissolves "an union," a pearl, "richer than that which four successive kings / In Denmark's crown have worn" (5.2.244-6), he is echoing an act of Cleopatra specified by Sir Thomas Elyot as one of intemperance. Again, like Agamemnon's stepping on the blood-red carpets, there is a challenge to the gods in such extravagance. Like Spenser's Excesse, with her cup into which she squeezes grapes, Claudius's cup is held up in one hand, the pearl in the other. This act (sometimes seen as a parody of the mass) clearly falls into the category of a failure to "think mortal thoughts." Spenser's Guyon smashes the cup of Excesse to the ground. Claudius warns Gertrude verbally, but does not intervene physically to dash his cup of poisonous excess from her hand. Hamlet responds too late to Claudius's murderous intemperance, picking up the cup only after it has delivered its knowledge (and arguably self-knowledge) to Gertrude. 
The picture we gain of Claudius's behaviour through Hamlet's report is one of habitual excess, of an archetypally intemperate man. Hamlet (in his own version of extravagant desire) hopes to execute the king " $[\mathrm{w}]$ hen he is drunk asleep, or in his rage, / Or in th' incestuous pleasure of his bed, / At game a-swearing, or about some act / That has no relish of salvation in't' (3.3.89-92). It may be possible to dismiss this description as a characterisation of Claudius, both because of Hamlet's possible or probable unreliability as a reporter of Claudius's behaviour, so that (echoing the discussion of intellectual argument in the introduction), the apparent excess of the description weakens the sense of accompanying veracity, and because these behaviours are not directly enacted in the play. What is presented is Claudius's Agamemnon-like defiance of mortal limits in the centre of the play. Like Agamemnon and like Phaedra in Euripides' Hippolytus, Claudius is clear-sighted about his intemperance and the consequences of his failure to act against it. Agamemnon knows he is challenging the gods in stepping onto the blood-red carpets and failing to be temperate in doing so, and, the play suggests, suffers the consequences. Phaedra knows her lust for Hippolytus is morally unacceptable, that it involves lack of self-control, and could have disastrous consequences, and yet cannot summon that self-control. Claudius knows the extent of his sin. "O, my offense is rank, it smells to heaven; / It has the primal eldest curse upon't, / A brother's murder" (3.3.36-8). The roots of Claudius's sin, by his own comparative admission, lie in the earliest historical act of covetousness, Cain's murder of Abel, and like the imagery of Spenser's Boethian stanza, such covetousness, the wanting of what does not belong to you and is superfluous to need, has resulted in rank filth. Like Phaedra's dilemma, the full pathos of Claudius's position cannot be realised without some sense of a strong, clear-sighted but failed emotional struggle. He is trapped by the filth of the human condition that follows The Fall, and that has its roots in excessive desire. He also knows clear-sightedly the potential power of grace to those who confess: "What if this cursed hand / Were thicker than itself with brother's blood, / Is there not rain in the sweet heavens / To wash it white as snow?" (3.3.43-6). But he cannot give up "my crown, mine own ambition, and my queen" (3.3.55). He is, then, in Spenser's terms “captiu'd to covertise" (II.vii.15.2). Mammon, as Guyon says, confounds both realms and rulers: "Witnesse the guiltlesse blood pourd oft on ground, / The crowned often slaine, the slayer cround, / The sacred Diademe in peeces rent...So mak'st thou kings, and gaynest wrongfull gouernment" (II.vii.4-9). Claudius has failed to realise, in the Boethian sense, "how small allowance, / Vntroubled Nature doth her selfe suffise" (II.vii.3-4) - the sense demonstrated in Hamlet by the man who is not "passion's slave" 
(3.2.62), Horatio, who "no revenue hast but thy good spirits / To feed and clothe thee" (3.2.48-9). But like Phaedra, and in part (and it is one of the puzzles until the end of the play whether desire for Gertrude or the crown predominates) because of a similar passion, Claudius's "bosom black as death" (3.3.67) and "limed soul" (3.3.68) is trapped in the filth of desire that has overstepped both human and divine limits. Claudius's intemperance, in the Aristotelian sense to which I will return in subsequent chapters, is entrenched.

But this view of Claudius's intemperance comes to us in the main through the (I am arguing) genuine pathos of his central soliloquy and Hamlet's report. The face Claudius presents to the court is one of admirable and reasonable self-control. As with Spenser's Bower of Bliss, Claudius's intemperance is disguised by the appearance of temperance. His speech in Act One Scene Two wins over the court to his succession; he is decisive in his actions over the threatened war; he is calm and in control: he is, in other words, kingly. He represents stability in the face of potential disorder, and it is easy to overlook the fact that the unplanned succession for which Claudius is directly responsible has itself caused the potential for disorder and external attack. The sequence of threatened disorder and calm authority reestablishing control is replayed after the death of Polonius, when Laertes brings a mob demanding justice to the gates of the palace. Claudius epitomises kingly calm and reasonableness, even in the face of Laertes' desire for revenge and a direct threat to his physical safety (4.5.116). Following the confession, the audience now knows that, in Hamlet's phrase, Claudius is a "smiling, damned villain" (1.5.106), and any early distrust of him is confirmed, but nevertheless this understanding is experienced more intellectually than emotionally because of the skill of Claudius's oratory. It is only when Gertrude sees through the mechanism of the poisoning at the end of the play that the spell of the reasonable response is finally broken on stage.

The audience's experience of Claudius's reasonableness, and the sense that the scale of his own tragedy is hidden, is partly caused by the overwhelming projection of Hamlet's contrasting expressions of lack of emotional control. And if Claudius is like Phaedra in showing a clear self-knowledge of the nature of his intemperance, Hamlet is like Hippolytus in his inability to see the intemperance in his own acts of chastising the intemperance of others. One of the large issues of critical commentary on Hamlet (like that on the status of Othello) surrounds the extent of his self-knowledge at the end of the play. When Barnardo questions Horatio about the meaning of the appearance of the ghost at the beginning of the play, Horatio says it is "a mote...to trouble the mind's 
eye" (1.1.112). The difficulty with the Biblical mote is that seeing one in another's eye can prevent you seeing the plank in your own. Hamlet, in seeing the intemperance of many of the other characters in the play, has trouble seeing his own responses as intemperate. Hamlet's rejection of Ophelia is not unlike Hippolytus' rejection of Phaedra: it sees all women as a threat to purity (a traditional aspect of temperance as we have seen in the introduction), to temperance in the sense of chastity, and it is lifedenying, like Hippolytus's speech to Phaedra, of the life-affirming procreative power of love. It is (and again in watching the "Mousetrap" play when Hamlet also breaches social decorum) cruel in its effect, like Hippolytus' denunciation of Phaedra. This cruel rejection contributes to Ophelia's tragic end. Hamlet's grief over Ophelia's grave is real, but does not include any overt acknowledgement of any personal responsibility for this tragic outcome, and so an accompanying self-knowledge. And this lack of selfknowledge may have at its root something like the Sophoclean lack of sophrosyne as delusion, a failure of "soundness of mind."

Hamlet's bad faith, hypocrisy, or lack of self-knowledge is most strongly in evidence in his chastising of Gertrude in the closet scene, and it is also here that the question of his sanity becomes most pointed. Like his rejection of Ophelia, his attack on Gertrude is also unnecessarily cruel and insulting; it breaches all decorum, and goes in every way to excess. Hamlet is unable to relate his own self-righteous excess in denunciation, or his own immediately preceding act of impulsive irascibility and murder, to the moral excess he condemns.

But just as the audience is made to feel uneasy by Claudius's oratorical justifications but are also ensnared by the moderation and self-control of his delivery, sympathy for Hamlet is maintained even at his most irrationally excessive, in part because of his moments of quiet and calm, eyes in the storm of his emotional frenzies. One of these moments is his central praise of Horatio, and the passionate control of his advice to the players. Another, at the beginning of the play, is his quiet appraisal of his dead father, balancing deep and affectionate respect and sorrow with realism. "“A was a man, take him for all and all, / I shall not look upon his like again" (1.2.187-8). Hamlet's ironic mockery of Polonius and Osric, his wit, also arises from a controlled intelligence. The speeches over the skull of Yorick are also calm in their reflection, and may be part of a deeper process of developing selfknowledge. Trying to ascertain where to place Hamlet on a continuum between calm insight and delusion in most other moments is part of the puzzle of the play. The closet scene presents the conundrum most intensely. 
Hamlet's desire to chastise his mother is a strong element of the Saxo Grammaticus source. That the remains of the spy who interrupts this counsel in Saxo Grammaticus are fed to the swine is suggestive of the bestiality of Acrasia and her victims in FQII, and Shakespeare may have incorporated this aspect of the original when Hamlet berates his mother for living "in the rank sweat of an enseamed bed, / Stewed in corruption, honeying and making love / Over the nasty sty" (3.4.93-5). The scene of counsel remains key in Shakespeare's play, and when read in terms of temperance can be seen as an extraordinarily taut set of contrasting variations on a theme. Hamlet's desire (against the direct admonition of the ghost) is to bring his mother to self-knowledge. If the ghost can be seen in any sense as parallel to Spenser's "Selfe," the inner voice "who wondrous things concerning our welfare, / And strange phantomes doth lett vs oft foresee, / And ofte of secret ill bids vs beware" (II.xii.47.5-7), then Hamlet is acting against this voice, one that has urged leaving Gertrude to "heaven / And to those thorns that in her bosom lodge / To prick and sting her" (1.5.86-8). Hamlet is guilty, then, of a failure to "think mortal thoughts" in taking on heaven's role and attempting to bring his mother to the point of repentance to which his "Mousetrap" play has (unbeknownst to him) brought Claudius.

The conclusion of the play, however, shows the urgency of this reformation of Gertrude, an issue of both her mortal life and immortal soul. Hamlet (to use the analogy of Guyon's knocking away the cup of Excesse) attempts to intervene between Gertrude and what he sees as her ready acquiescence in incontinence, to knock away in Spenser's terms the poisoned chalice of Acrasia. This desire to reform, however, is presented in a form that is sanctimonious in the extreme, and that escalates to breaches of social decorum laced with cruelty. Like Hippolytus, Hamlet is excessive in every way. The delivery is laden with dramatic irony, because it is preceded by Hamlet's own impulsive and reckless (in the sense of failing to reckon consequences) act of murder. That reforming his mother is such an act of urgency for Hamlet explains in part his lack of initial response to this act of murder; that he sees it as a trifle in the way of his higher purpose in itself signals a lack of selfknowledge. Gertrude's actions have, in his view, as he begins to berate his mother, sullied all pure love, a view with which Hamlet claims heaven would agree. “Heaven's face doth glow; / Yea, this solidity and compound mass / With tristful visage as against the doom, / Is thought-sick at the act" (3.4.34). Hamlet follows the comparison of the two brothers with the accusation that Gertrude herself is guilty of 
something close to a lack of "soundness of mind." "Sense sure you have, / Else could you not have motion, but sure that sense / Is apoplexed, for madness would not err, / Nor sense to ecstasy was ne'er so thralled / But it reserved some quantity of choice / To serve in such a difference" (3.4.71-6). Hamlet's accusations escalate the sense of a lack of controlling reason to the point where reason (using the line of metaphor already established with Ophelia) prostitutes subsequent action. If a comparatively elderly mother cannot see the difference between husband and brother and resist temptation (and we have seen that old men falling victim to Venus is a conventional example of intemperance), what hope is there for a young man like Hamlet? "Proclaim no shame / When the compulsive ardor gives the charge, / Since frost itself as actively doth burn / And reason panders will" (3.4.85-7).

Hamlet's desire to trigger self-knowledge in Gertrude appears at this point to be successful. Gertrude's response replays the attempted confession we have just seen from Claudius in a minor key. “O Hamlet, speak no more. / Thou turn'st mine eyes into my very soul, / And there I see such black and grained spots / As will not leave their tinct" (3.4.88-91). But Hamlet cannot stop there. His emotional excess becomes counter-productive, for the very reasons he has given the actors against histrionic acting. It loses credibility as it reaches a tipping point of extremity from which Hamlet cannot pull back. This extremity manifests itself as a lack of soundness of mind, of the delusion we see in Sophocles. "Alas," responds Gertrude, "he's mad" (3.4.105). Her response is to request him (as previously discussed) to "[u]pon the heat and flame of thy distemper / Sprinkle cool patience" (3.4.121-3). The ghost has just offered the same advice for Gertrude through Hamlet, a projection perhaps of Hamlet's sense of his own tenuous hold on reason over imagination: "Oh step between her and her fighting soul: / Conceit in weakest bodies strongest works" (3.4.112-3). Gertrude's diagnosis is unequivocal: "This is the very coinage of your brain. / This bodiless creation ecstasy / Is very cunning in" (3.4.138-40).

Upon the exit of the ghost, Hamlet returns to a calmer admonition of Gertrude. He claims a temperate harmony of body and mind. He is most concerned that an accusation of madness should not detract from his message of temperance to Gertrude: "for love of grace, / Lay not that flattering unction to your soul, / That not your trespass but my madness speaks" (3.4.145-7). The problem of seeing what is true and what is not becomes urgent, for rejecting the message because of the messenger has the potential to "skin and film the ulcerous place / Whiles rank corruption, mining all within, / Infects unseen" (3.4.148-150). The metaphor of rank 
corruption mining all within also stands in Hamlet's mind for the problem with Elsinore. It is essentially the same metaphor of "honeying and making love / Over the nasty sty" (3.4.93-4), a metaphor that could also stand for the activity of Spenser's Bower of Bliss. But Hamlet's advice - not to "spread the compost on the weeds / To make them ranker" (3.4.152-3) - is almost immediately undermined by his own self-styling as "virtue." It is possible that these lines could be delivered ironically, but even so, they still convey Hamlet's lack of self-knowledge, his sense that he is exempt from the intemperance of others: "Forgive me this my virtue, / For in the fatness of these pursy times / Virtue itself of vice must pardon beg, / Yea, curb and woo for leave to do him good" (3.4.153-6).

The apology, though, has a tenor of a more moderate interaction, as if Hamlet is returning to himself. Hamlet then argues for a habituation to abstinence on Gertrude's part, an echo of the process of acquiring and begetting temperance demanded of the players. It is not until this point that he returns to the body of the man he has himself slain. Now he is calm, he has a rational, if despairing, selfjustification for the murder - it signals his role as "scourge and minister," (and it is about this role that some of the deepest issues of Hamlet's self-knowledge or lack of it will revolve, and which the next chapter will pursue more fully). At this point he has sufficient distance from his passionate delivery to justify his excessive language, a justification that must essentially be that of Guyon's destruction of the Bower of Bliss: "I must be cruel only to be kind" (3.4.179). His foresight into the implications of Polonius' death is accurate: "Thus bad begins, and worse remains behind" (3.4.180). Now calm, he tells Gertrude that he is "mad in craft" (3.4.188), but with no apparent insight into how the appearance of the ghost has made him seem to Gertrude. But then some remnants of his rage return, though in a controlled and mocking form. He creates a strong visual image of intemperate lust in his request to keep the secret of his contrived madness hidden. Gertrude should not "Let the bloat king tempt you again to bed, / Pinch wanton on your cheek, call you his mouse, / And let him for a pair of reechy kisses, / Or paddling in your neck with his damned fingers, / Make you to ravel all this matter out..." (3.4.183-7). As a result, it seems, of this potential image, Hamlet then resorts to sarcasm. Gertrude is not in Hamlet's eyes "a queen, fair, sober, wise" (3.4.190) (the type of a Euripidean sophron woman like Andromache), and must be implicitly threatened not to pass on the secret. Hamlet ends the scene calmly, with wit and judgement on Polonius, but again with no sense of any possible intemperance in the counselling he has himself just given. 
"Indeed, this counsellor / Is now most still, most secret, and most grave, / Who was in life a foolish prating knave" (3.4.214-6).

At the end of the play, when Gertrude proclaims "No, no, the drink, the drink - O my dear Hamlet - / The drink, the drink - I am poisoned" (5.2.290-91), there is a strong suggestion of an underlying self-knowledge to which Hamlet's counselling in the closet scene has brought her. She has at the very least seen the justice of Hamlet's accusation of murder against Claudius, and her appeal to Hamlet may acknowledge the rest of his case. Laertes' final appeal to Hamlet, a sort of repentance, results from some insight into his own entrapment in Claudius's murderous purposes, and may amount to a form of self-knowledge: "Mine and my father's death come not upon thee, / Nor thine on me" (5.2.309-10). The difficult question about Hamlet is whether he has also moved to a deeper Sophoclean self-knowledge in the second half of the play, a preparation for the death that awaits him, or whether he has in some sense changed places with Claudius (once Claudius has been brought to the self-knowledge that cannot guide his action in the centre of the play), and become seduced by his own oratory into all separation from moral responsibility for the effects of his actions on others: whether, in other words, he dies lacking all insight into his own forms of intemperance. Shakespeare's judgement on Hamlet, not unlike his judgement on Othello, or Euripides' judgement on Hippolytus and Theseus, may in some ways be reasonably hard. 


\section{Chapter Four: Archetypes, revenge and original sin}

In this chapter we will move from an essentially mimetic reading of temperance in Hamlet in terms of conflicting aspects of the intemperance of individuals, to favour the allegorical basis of Spenser's legend of temperance and its use of archetypal imagery. We will also move from the furthest historical roots of temperance as a classical virtue to sources of Christian theology immediate to the Elizabethan period, its state articles of faith and official Church homilies. Readings of Hamlet in terms of archetypes of original sin are debated but not new - a comparison with $F Q I I$ makes it harder to ignore their presence in Shakespeare's play without in itself resolving the issue of the balance of weight to give the archetypal or the mimetic. The comparisons in this chapter will deal particularly with its imagery of corruption and the poisonous effects of concupiscence, and will focus on temperance as action taken - revenge - against the fallen self.

Both FQII and Hamlet end in acts of violence. Guyon and his Palmer bind Acrasia in adamantine chains and then destroy the contrived beauty of the Bower of Bliss. Hamlet ends with bodies strewn across the stage and with deception uncovered. In both works there is a tension between the need to become temperate oneself and the desire to reform others, and I have suggested in the previous chapter this tension involves problems of self-knowledge. $F Q I I$ is clearly delineated as a Christian and Protestant allegory. Its narrative is linked to the narrative of $F Q$, the Legend of Holiness, and an angel descends to the rescue of its protagonist in the centre of FQII. The theological dimensions of Hamlet are less easily established, and are rightly open to debate, but it cannot be avoided that the play contains a series of Christian references which lend themselves to a range of archetypal readings, readings made by different critics in the light of Augustinian, Calvinist and Thomist theology. Most problematic of the Christian allusions is Hamlet's styling himself in the role of "scourge and minister," because this designation blurs the lines between secular personal or political revenge and religious chastisement. This chapter then pursues the overtly religious dimensions of both works, and in the case of Hamlet the most archetypal elements, and their relationship to the virtue of temperance.

Both Guyon's zealous act of destruction of the Bower of Bliss, and Hamlet's self-styling as "scourge and minister," seem initially to be incompatible with the moderation and self-control that are associated with the virtue of temperance. In Christian theology, Christ's action against the money-lenders in the temple is cited in defence of violent acts of purging corruption. The place of violent admonition in a 
legend of temperance and a tragedy concerned with temperance also becomes clearer when we realise there are classical precedents for such zealous and sometimes violent admonition as acts of bringing temperance to others, that this is in fact a traditional aspect of temperance as a concept. The Greek concept of sophrosyne always allowed for the role of the chastiser, the person whose role it was to make others temperate. Apollo often has this active role, as he does in his punishment of Agamemnon in the Iliad and, it is important to note, such a chastiser was not required to act temperately himself in the process of making others temperate (North From Myth to Icon 63). In Aeschylus' Persians (as Helen North explains) it is Zeus Kolastes (the Corrector) who is offended by Persian hybris and impiety (North 35). On the other hand, in the Seven against Thebes, Thebes is saved because its cause is just and its champions are temperate, while the attackers are hybristic. The discourse of the sophronistae, who correct the behaviour of others, also operated in the politics of Athens; sometimes it was the oligarchs who attempted to correct the behaviour of others, and sometimes the democrats were in turn sophronistae for the oligarchs. In Plato's Laws the connotations of this aspect of sophrosyne are seen when the reformatory for those accused of impiety by reason of folly is called the Sophronisterion (House of Correction) (North From Myth to Icon 115). The officer who supervised the morals of the Athenian ephebes was called Sophronistes. These men over forty years, one from each tribe, looked after the ephebes who were expected to learn discipline, orderliness and self-control (North 195).

Two strands of thinking, Greek and Hebraic, come together when this act of reforming others is Christianised, and it is this combined tradition that feeds into the constant language of admonition of FQII and Hamlet. When Ambrose presented a bridle containing a nail from the True Cross to Constantine as a symbol for the ruler of the need to curb his insolence and restrain his lust, he is described as a sophronistes (367). Thus a classical tradition feeds into the Old Testament tradition of the prophet as scourge, a tradition that is also applied to Christ in the overturning of the tables of the money-lenders in the Temple. The act of bringing moderation and self-control to others, whether through direct action or the language of admonition, does not in either tradition need to be in itself expressed moderately. A clear example of the violence of the language of admonition in the early Christian church is seen in Clement's Paedagogus, which emphasises the salutary importance of reproof in Christian life, to bring a health of soul in the tradition of the original etymology of sophrosyne as health of the phrenes. 
Reproof is, as it were, the surgery of the passions of the soul; and the passions are, as it were, an abscess of the truth, which must be cut open by an incision of the lancet of reproof. Reproach is like the application of medicines, dissolving the callosities of the passions, and purging the impurities of the lewdness of the life; and in addition, reducing the excrescences of pride, restoring the patient to the healthy and true state of humanity. Admonition is as it were, the regimen of the diseased soul, prescribing what it must take, and forbidding what it must not. And all these tend to salvation and eternal health. (Clement 225; I.viii)

Clement directly links Christ as Instructor with the role of scourge. "For the Instructor also, in virtue of His being good, with consummate art glides into censure by rebuke, rousing the sluggishness of the mind by His sharp words as by a scourge" (226; I.viii). The further step of denunciation can rouse the sleeper from deep sleep. John 15.1, 2 - "I am the true vine, and my father is the husbandman" - is used as an example. The Word as a knife "clears away the wanton shoots; compelling the impulses of the soul to fructify, not to indulge in lust" (226; I, viii).

Clement, however, quite specifically rules out God's judgement as a form of revenge.

Now hatred of evil attends the good man, in virtue of His being in nature good. Wherefore I will grant that He punishes the disobedient (for punishment is for the good and advantage of him who is punished, for it is the correction of a refractory subject); but I will not grant that He wishes to take vengeance. Revenge is retribution for evil, imposed for the advantage of him who takes the revenge. He will not desire us to take revenge, who teaches us to 'pray for those who despitefully use us'. (227; I.viii)

But it is "not inconsistent with the saving Word, to administer rebuke dictated by solicitude. For this is the medicine of the divine love to man, by which the blush of modesty breaks forth, and shame at sin supervenes" (228; I.viii). Instead the actions of the Instructor proceed in the following way: he "testifies to the good, and summons forth to better things those that are called; dissuades those that are hastening to do wrong from the attempt, and exhorts them to turn to a better life" (228; I.viii). Thus the Divine Word "devotes Himself to the saving of the children, admonishing, upbraiding, blaming, chiding, reproving, threatening, healing, promising, favouring; and as it were, by many reins, curbing the irrational impulses of humanity" (228; I.ix). Curbing the irrational impulses of humanity with many reins has strong overtones of the Platonic charioteer and the discourse of restraint that traditionally surrounds temperance.

Admonition, as the censure of loving care, produces understanding. Clement gives the example of the Gospel (Matthew 23. 37) "How often would I have gathered 
thy children, as a bird gathers her young ones under her wings, and ye would not!" (qtd 228, I. ix). Reproof is defined as the bringing forth of sin and laying it before the sinner. Proverbs 3. 11-12 is also given as a source, with the explicit use of the language of scourging. "My son, despise not thou the chastening of the LORD; nor faint when thou are rebuked of Him: for whom the LORD loveth he chasteneth, and scourgeth every son whom He receiveth" (qtd 229; I.ix).

The Easter Sermon ("Of the Resurrection of Our Saviour Jesus Christ") in the official Elizabethan homilies, directly familiar to Spenser's readers and Shakespeare's audience, contains language of violent admonition that follows this patristic tradition. Easter is seen as the time to kill and offer up the sins of the body as Christ was offered up for redemption.

Trueth it is that sinne is strong, and affections unruly. Hard it is to subdue and resist our nature, so corrupt and leauened with the sower bitternesse of the poyson which we have received by the inheritance of our old father Adam....Though your power bee weake, yet Christ is risen againe to strengthen you in your battaile, his holy Spirit shall helpe your infirmities. In trust of his mercy, take you in hand to purge this olde leauen of sinne, that corrupteth and sowreth the sweetenesse of our life before GOD, that yee may bee as newe and fresh dow, voyde of all sower leauen of wickedness. (Pt 3)

What is perhaps most unexpected is the sermon's expression of the need for this purgation in terms of killing.

I say kill \& offer you vp the worldly and earthly affections of your bodies. For Christ our Easter Lambe is offered vp for vs, to slay the power of sinne, to deliver vs from the danger thereof, and to give vs example to die to sinne in our lives". (ibid)

The rebuke is also explicitly not for the unregenerate, but delivered to those, already saved, who risk regression away from righteousness.

In FQII the act of killing allegorical representatives of the "worldly and earthly affections of the body" occurs when Arthur fights and kills Pyrochles and Cymochles (usually interpreted as the concupiscent and irascible appetites), and when Arthur strangles and subsequently drowns Maleger in a standing lake (usually interpreted as an act of baptism). Both acts amount to the battle through which the risen Christ strengthens the weak human to fight against the poison of the Old Adam, the worldly and earthly affections of the body.

To escape from the filthiness of the world can also carry overtones of neoplatonic purification in writers like Augustine. Here such purification is not only Christianised, but directly associated with temperance. In the early Augustinian De 
Ordine, temperance, conversion and purification away from the "mud and filth" of the body are identified with each other.

After all, from what things do you think we pray to be turned towards [convertamur] God so that we can see his face, if not from the mud and filth of the body, and similarly from the shadows in which error wraps us? And what is it to be turned [converti] if not to turn away from the excesses of vice, and to be raised into ourselves by virtue and temperance? (1.8.23)

In De Moribus Ecclesiae, Augustine's central definition of temperance, "love giving itself entire and incorrupt for God," (15.25) is given in terms of a delivery from the Old Adam in us. "The whole duty of temperance... is to put off the old man and be renewed in God - that is, to scorn all bodily delights, and the popular applause, and to turn the whole love to things divine and unseen" (19.36). Temperance, as an act of rejecting everything that is associated with the Old Adam, thus becomes pivotal in the moment of conversion to God and spiritual renewal. This Augustinian view of temperance as Pauline spiritual renewal achieved as an act of love underlies Spenser's conception of temperance in $F Q I I$ in my view, a point to which I will return in a range of ways.

The complication for a battle of temperance with the Old Adam in the fallen self in Christian and particularly Calvinist theology is that the effects of original sin always remain, even in the regenerated. The official Elizabethan church line is given in the ninth article of the Elizabethan church settlement.

Original sin standeth not in the following of Adam, (as the Pelagians do vainly talk) but it is the fault and corruption of the Nature of every man, that naturally is engendered of the offspring of Adam; whereby man is very far gone from original righteousness, and is of his own nature inclined to evil, so that the flesh lusteth always contrary to the Spirit, and therefore in every person born in this world it deserveth God's wrath and damnation. And this infection of nature doth remain, yea in them that are regenerated; whereby the lust of the flesh, called in Greek, phronema sarchos (which some do expound the wisdom, some sensuality, some the affection, some the desire, of the flesh), is not subject to the Law of God. And although there is no condemnation for them that believe and are baptized; yet the Apostle doth confess, that concupiscence and lust hath of itself the nature of sin. (Articles of Religion, IX)

This article, written as it is in a highly-charged political context at the beginning of Elizabeth's newly Protestant reign, amounts to a kind of theological compromise that leans strongly towards the Calvinist position, and is noticeably less optimistic than the Easter homily. While the Easter sermon proclaims the potential for the believer, in partaking in Christ's crucifixion and resurrection, to become "as 
newe and fresh dow, voyde of all sowe leauen of wickedness" (Pt 3), the article is more cautious, claiming only that "there is no condemnation for them that believe and are baptized." But it is also making it clear that no complete extirpation of innate concupiscence is possible, that even in the regenerate, innate concupiscence both remains and has the nature of sin and cannot be escaped.

The tension between the relative optimism of the Easter homily, and the pessimism in regard to the lingering effects of innate concupiscence in the ninth article of the official articles of faith of the established church, is reflected in Spenser criticism, with an increasing tendency to move towards the Calvinist position, and I will provide here some representative examples of this trend. We see this in the movement away from reading Guyon's action against Acrasia in the Bower as an absolute victory. In 1958, in "A Theological Reading of The Faerie Queene, Book II," A.C. Hamilton argued "that the bloody-handed Babe stands for mankind which from its infancy has been infected by original sin. (Blood upon the hands being the usual token of man's guilty state)," and defined Acrasia as "Intemperance, seen as an enchanting woman" (156). As an analogy, Acrasia is, for Hamilton, Eve in her Garden of Eden, and Eve is seen as the source of Adam's death and the stain of original sin on the human race. Guyon's quest is to undo the effects of the Fall, and "to assert the power of the temperate body over sin" (156). Guyon, in Hamilton's view, successfully triumphs over this second Eve, and Arthur over a Maleger who represents the Old Adam of the Thirty-Nine Articles cited above, that is original sin. Arthur's defeat of Maleger cleans the blood of original sin from the hands of the babe, and so Guyon can proceed triumphantly (unlike the Gryll who refuses to be made regenerate). Patrick Cullen, similarly, saw Guyon as performing a complete imitation of Christ in the Bower of Bliss, something he fails to do in the Cave of Mammon episode (Cullen 68). This final triumph is possible through a dependence on grace.

Harry Berger, drawing particularly on Augustinian thought (and the Thomist interpretation of temperance of Josef Pieper), is both optimistic and pessimistic about the ultimate outcome of temperance achieved through spiritual renewal. He sees grace, signalled by the arrival of the angel half way through the legend, as leading to "a moral harmony which yet reaches down to 'the existential core of man,' a perfecting and reordering even of instinct, with which man may have nothing to do, of which he need not even be aware" (Berger 62). The effect of grace is "a profound process, working beneath and above and in spite of consciousness" (62). But despite 
the at times unconscious operation of this process, Berger clearly sees human action as in co-operation with grace in the acquisition of temperance, an acquisition which he sees as the duty of all Christians, in a manner not unlike the Easter homily but which for the Calvinist may smack of a Catholic reliance on works. This point emerges in his discussion of krasis or "proper mixing."

\begin{abstract}
Krasis as a blending, an ethical climate in the soul, becomes more than a starting point, more than an accidental happiness of disposition; it comes as the result of a course of action on the part of the human will - an acquired virtue which may be perfected by grace. As a goal to be reached, the result of Temperance, it is not merely the gift of a fortunate few, but the obligation of Everyman. (Berger 67)
\end{abstract}

Berger clearly sees temperance as a moral imperative for all, and one for which every Christian should actively strive. He also sees the flesh as something to be celebrated and not repressed, directly rejecting both the neo-Platonic and Calvinist in discussion of the House of Alma. Instead, Berger describes Spenser's portrayal of the body as Pauline and Augustinian, and cites in support The City of God XIV.5: "There is no need... that in our sins and vices we accuse the nature of the flesh to the injury of the Creator, for in its own kind and degree the flesh is good" (qtd Berger 68). Like Augustine, Berger's focus is on the corruption of the will, and he stresses that it is this corruption, and not just that of the body, that Christian temperance must combat. Guyon, in the Bower of Bliss episode, is involved, in Berger's reading, not in a Platonic struggle of reason against lust, but in a primal Pauline battle with an enemy of God competing with the Divine Creation.

Carol Kaske's analysis of the episode of Mordant and Amavia in terms of Romans 7 and Augustinian psychology complicates and deepens Berger's portrayal of a primal battle in the soul between the spirit that is of God and the spirit of the world by showing how the dice are, as it were, stacked against the will, both because of original sin and through the revelation of innate sinfulness by the Mosaic Law. Kaske looks at Augustine's interpretation of Romans 7.7. "I had not known sin, but for the law: for I had not known lust, except the law had said, thou shalt not covet. But sin, taking occasion by the commandment, wrought in me all manner of concupiscence. For without the law sin was dead. For I was alive without the law once: but when the commandment came, sin revived and I died" (Kaske 93). The Augustinian negative suggestibility of the Confessions (neatly summarised by Kaske as "if you tell a boy not to pick pears, the first thing he'll want to do is pick pears" (93)) explains why Amavia's attempt to reform Mordant after his seduction by 
concupiscence in itself leads inevitably to his spiritual death. Moral reformation, in the classical sense of the action of rational control, cannot account for the moral paradox that people will still pursue an immoral act while understanding it to be immoral. More strongly, in Pauline terms, knowledge that an act is immoral becomes the occasion of sin, a paradoxically active seduction to sin. The only away around this paradox is the action of grace to release the will from the restrictions of the Law. Acrasia's poisoned stirrup cup of wine thus becomes identified by Kaske with the forbidden fruit that brought death to Adam and Spenser's Mordant as Mortdant ("him that death does giue" (II.i.55.4) (Kaske 95).

The odds of moral reformation are stacked against the Christian, both if what must be reformed is not passion by reason, but an innate corruption that affects body, soul and will, and if a rational understanding of moral prohibition increases rather than diminishes the likelihood of the will choosing for ill. The Augustinian and Calvinist doctrine of election predetermines who will choose for good, and who for ill, and makes the ability to choose for good entirely a matter of the operation of divine grace. Richard Mallette demonstrates the Elizabethan position on election through William Perkins, who in 1598 describes the sinner as a prisoner who is not only sick but "starke dead", and who cannot stir for his own release until God implants a new soul in him (Mallette 2).

Richard McCabe's study, The Pillars of Eternity: Time and Providence in The Faerie Queene, argues that “Calvin's doctrine of the relationship between grace and will was one of the most contentious tenets of reformed theology" (171), and also the issue that most clearly distinguished Calvin from his Anglican and Catholic opponents. For Calvin, free will means being enslaved to sin and free to commit sin. McCabe cites the Institutes: "simply to will is of man; to will ill, of a corrupt nature; to will well, of grace" (qtd McCabe 171). Through regeneration, election recreates the will: "Because of the bondage of sin by which the will is held bound, it cannot move towards good, much less apply itself thereto; for a movement of this sort is the beginning of conversion to God, which in Scripture is ascribed entirely to God's grace" (qtd McCabe 171-2). This accounts for Guyon's rescue by divine grace at the end of the Cave of Mammon episode while in a state of complete dependence, while the Pyrochles who dies at Arthur's hand represents the reprobate whose heart has been hardened against accepting grace.

But we must note McCabe is not completely confident in attributing an absolute Calvinist position to Spenser. Arguing from A View of the Present State of 
Ireland, he sees Spenser's application of the doctrine of election as a generous one: “Spenser has no doubt, for example, that 'many' Catholics will receive saving grace despite the corruptions of their Church" (175), although they may first need to convert to the Protestant belief system. In his discussion of the differences between Calvin, on the one side, and Hooker and Erasmus on the other, on I Corinthians 15.10 - "I laboured more abundantly than they all: yet not I, but the grace of God that was in me," - McCabe also sees (in what may either be a generous fudging or quite acutely help us to see where Spenser is positioned), "many apparent inaccuracies in Spenser's treatment of grace" as reflecting "unresolved tensions in Reformed theology compounded by the artistic demands of an intricate story-line" (176). On the one hand, the position that "nothing is ours but sin" becomes deterministic (and McCabe cites Hooker's words), “making man little more than a block" (177). On the other hand, McCabe argues, "Spenser...greatly values human endeavour and the concept of spiritual trial which seems to inform most of the quests bespeaks a keen interest in the workings of the will" (177). Because in cases of trial attention becomes focussed on the painful process, it becomes hard not to want to talk in terms of free will: "however efficacious the grace, its recipient feels isolated" (177). But this would be to misread Spenser, in McCabe's opinion. "The most that may safely be said is that Spenser pursues a cautious course between the second book of the Institutes and the articles of the Established Church, themselves strongly influenced by Calvinism" (177).

Daryl Gless also favours a more Calvinist position in Spenser's treatment of temperance, and highlights the problem that even after regeneration, the reason will always be operating in the dark - unless directly illuminated at a particular moment by divine revelation. The effect is that "Guyon manifests blindness to issues that are too deep, theology would maintain, for reason's and morality's reach” (Gless 182). Gless gives Guyon's “pat” (182) response to the deaths of Mordant and Amavia as an example of the limitations of temperance as rational self-control from a Reformed perspective. In Gless's reading, Guyon's destruction of the Bower of Bliss, his tempest of wrathfulness, cannot be entirely equated with the execution of a just dispassionate anger, because Guyon "corrupts the good works he performs" (191). But Gless argues this both ways, claiming that Guyon still "remains a true colleague of the knight of holiness" (191), in the same way as he sees both sinfulness and lack of sinfulness in Guyon's entry into the Cave of Mammon. Gless concludes that the 
fact "neither the knight nor his palmer perceives flaws in their achievement provides a final reminder that temperance is a limited virtue" (191).

Gless, Mallette and McCabe have moved a long way from the triumphant view of Hamilton and Cullen of the conclusion of $F Q I I$. The theological position they present is closer to the cautiously worded Article IX of Elizabethan faith, than the confident exhortation of the Elizabethan Easter homily which promises that by killing and offering up the passions of body the Elizabethan churchgoer can be made as new dough, void of all wickedness. It is with these tensions in mind that we will begin to trace some of the imagery of concupiscence that threads its way through the legend of temperance and contributes to its problematic denouement. As Spenser points out in the Letter to Raleigh, his poetic approach is different from the offering of "good discipline deliuered plainly in the way of precepts or sermoned at large" (Hamilton 716). And one of his poetic tricks, I suggest, is, through the operation of what I would like to describe as a poetic caress or seduction of language, to take the reader inside the skin of concupiscence, showing us how subtly it operates to infect the will.

\section{"Hard it is to subdue and resist our nature"}

Mordant, "him that death does giue", dies in the first canto of $F Q I I$, when he drinks from a charmed cup given to him by Acrasia and fulfils the charm "Sad verse, give death to him that death does give, / And losse of loue, to her that loues to liue" (II.i.55.4-5). One way of seeing this episode is that Mordant gives death in the way the old Adam in man brings death. Carol Kaske, as we have seen, has elucidated this passage in terms of knowledge of the Law (95). Amavia describes attempting to reform her wayward lord: "through wise handling and faire gouernaunce, / I him recured to a better will" (II.i.54.6-7). But as the Law brings an overwhelming knowledge of human sinfulness, Mordant is overcome when the cup of Acrasia comes into contact with the pure waters of a well. Guyon and the Palmer bury the bodies of Mordant and Amavia and swear an oath of "dew vengeance."

Such and such euil God on Guyon reare,

And worse and worse young Orphane be thy payne,

If I or thou dew vengeance doe forbeare,

Til guiltie blood her guerdon doe obtayne:

So shedding many teares, they closd the earth agayne. (II.i.61.5-9) 
This "dew vengeance" for the deaths of Mordant and Amavia becomes transformed into a project of education for their offspring. Guyon and the Palmer leave the Babe with the blood-stained hands with Medina and,

Did earnestly committ, and her coniure,

In vertuous lore to traine his tender youth,

And all that gentle noriture ensueth:

And that so soone as ryper yeares he raught,

He might for memory of that dayes ruth,

Be called Ruddymane, and thereby taught,

T'auenge his Parents death on them, that had it wrought. (II.iii.2.1-9)

To be trained in "vertuous lore" and to avenge his parents' death become associated if not identical tasks, if both are directed at the Old Adam in humankind. When Guyon has been unable to wash the blood from the infant's hands he has become puzzled, and we are given the first indication that the bodies of Mordant and Amavia have not remained securely buried.

He wist not whether blott of fowle offence

Might not be purgd with water nor with bath;

Or that high God, in lieu of innocence,

Imprinted had that token of his wrath,

To shew how sore bloodguiltinesse he hat'th;

Or that the charme and veneme, which they dronck,

Their blood with secret filth infected hath,

Being diffused through the sencelesse tronck,

That through the great contagion direful deadly stonck. (II.ii.4.1-9)

The babe's training in vertuous lore is to combat this "great contagion," the operation of "the veneme." The blood remains on the babe's hands as a "sacred Symbole" to "mind reuengement" (II.ii.10.7-8). Guyon gives the Babe to the Palmer to bear - the carrying we see in the Letter to Raleigh - and instead "his sad fathers armes with blood defilde, / An heauie load himselfe did lightly reare" (II.ii.11.3-4), and we are told in the next stanza "[h]is double burden did him sore disease" (II.ii.12.4). The role of Guyon, as one who buries the bodies of Mordant and Amavia and swears to avenge their deaths, and who leaves Ruddymane at the Castle of Medina to be educated, is complicated by this bearing of the burden of the armour of Mordant that, with his own armour, "doth him sore disease”(II.ii.12.4). 
The imagery of disease that begins with the deaths and burial of Mordant and Amavia and that is transmitted to Guyon through the bearing of Mordant's armour permeates the imagery of the poem in a range of ways. The most obvious is the description of the water across which Phaedria conveys Guyon. She first disposes of Cymochles on "The slouthfull waue of that great griesy lake" (II.vi.18.7), and then takes Guyon " $[\mathrm{t}]$ hrough the dull billowes thicke as troubled mire, / Whom nether wind out of their seat could forse, / Nor timely tides did driue out of their sluggish sourse" (II.vi.20.7-9). Pyrochles and Atin are described at the end of the canto as wrestling in these thick waves, which "so slow and sluggish were, / Engrost with mud, which did them fowle agrise, / That euery weighty thing they did vpbeare, / Ne ought mote euer sinck downe to the bottom there" (II.vi.46.6-9). When we come to the Cave of Mammon, we find the "blacke flood" of the "riuer of Cocytus deepe, / In which full many soules do endlesse wayle and weepe" (II.vii.56.7-9), and whose sad waves “direfull deadly stancke" (II.vii.57.3), as has the "troncke" of Mordant and Amavia. Both Tantalus and Pilate are found in this river. Pilate's carcase "deepe was drent / Within the riuer, which the same did hyde: / But both his handes most filthy feculent, / Aboue the water were on high extent, / And faynd to wash themselues incessantly, / Yet nothing cleaner were for such intent" (II.vii.61.2-7). As he explains, "[t]he whiles my handes I washt in purity, / The whiles my soule was soyld with fowle iniquity" (II.ii.62.8-9). Guyon seems to stand aloof from this corruption, and openly condemns Tantalus. In so doing he is guilty (as I have suggested in the previous chapter) of Pilate's own sin, that of thinking that his own soul has not been soiled by "fowle iniquity." And so a pride that also belongs to Guyon lies at the depths of the Cave of Mammon.

The taint of the Old Adam thus flows through the waterways of $F Q I I$ to the judgement that leads to the crucifixion. In Canto XI, the dead "troncke which direful deadly stoncke" (the less than securely buried bodies of Mordant and Amavia) returns to life to fight the champion of the pure body of the Castle of the Soul. The captain of the forces is Maleger. "Full large he was of limbe, and shoulders brode, / But of such subtile substance and vnsound, / That like a ghost he seem'd, whose graue-clothes were vnbound" (II.xi.20.7-9). He is etymologically desperately diseased and (as we have seen Gless argue) the Pauline "body of this death" that is the Old Adam in man. The battle with Maleger, fought by Arthur and his squire on behalf of the soul in Canto XI, runs parallel to Guyon and the Palmer's journey to the Bower of Bliss. While Maleger and his forces bring the diseased quality of fallen human nature out into the open, the Bower of Bliss disguises the insidious and seductive nature of concupiscence. 
The admonition of the Elizabethan homily to kill and offer up the worldly affections of the body proves difficult in both cases, however. Maleger will not die and keeps rebounding from the earth, so that Arthur doubted "least it were some magicall / Illusion, that did beguile his sense, / Or wandring ghost, that wanted funerall, / Or aery spirite vnder false pretence, / Or hellish feend raysd vp through diuelish science" (II.xi.39.5-9). Maleger is "most strong in most infirmitee" (II.xi.40.8), but curiously lacks substance. But because he draws his strength from the earth, from his carnal nature, he must be borne "farre from hope of succour vsuall" (II.xi.45.9) and cast into a standing lake. This is usually seen in Spenser criticism in terms of baptism. By casting Maleger into the standing lake, Arthur brings spiritual renewal.

\section{Concupiscence and the Bower of Bliss}

The Bower of Bliss requires a different sort of wrestling, this time with the attraction to pleasure. Guyon is attracted to the wandering islands, as we have already seen him wander in the earlier cantos. Even after the Palmer instructs him "doe them shonne; / For they haue ofte drawne many a wandring wight / Into most deadly daunger and distressed plight" (II.xii.11.7-9), Guyon responds: "Yet well they seeme to him, that farre doth vew / Both faire and fruitfull, and the grownd dispred, / With grassy green of delectable hew, / And the tall trees with leaues appareled / Are deckt with blossoms dyde in white and red" (II.xii.12.1-5). The risk of following their seductions, however, is of wandering "euer more vncertain and vnsure" (II.xii.12.9). Inside the Bower, the temptation of the two maidens in the fountain is even more seductive to Guyon, as the maidens see: "Now when they spyde the knight to slacke his pace, / Them to behold, and in his sparkling face / The secrete signes of kindled lust appeare, / Their wanton meriments they did encreace, / And to him beckned, to approch more neare, / And shewd him many sights, that corage cold could reare" (II.xii.68.4-9). The Palmer's rebuke to Guyon for his distraction and sensual arousal is followed immediately by an admonition to surprise Acrasia, "[e]ls she will slip away, and all our drift despise" (II.xii.69.9). These are the two sides of the same coin. Seduction prevents restraint.

And Guyon and his Palmer do successfully restrain Acrasia, with adamantine chains. But the process of creeping up on Acrasia to surprise her, from stanza 70 to stanza 81, when the pair throw a "subtile net" (II.xii.81.4) over the entangled lovers, is redolent with Spenserian ambiguity. The pair are entangled in the seductions of 
the lovemaking process. Firstly they hear sounds that are described as almost the sounds of heaven: "All that mote delight a daintie eare, / Such as attonce might not on liuing ground, / Saue in this Paradise, be heard elsewhere" (II.xii.71.2-4). If it is a parodic paradise, it is also parodic of a harmonious moment of sexual fulfilment.

The ioyous birdes shrouded in chearefull shade,

Their notes vnto the voice attempred sweet;

Th' Angelicall soft trembling voyces made

To th'instruments diuine respondence meet:

The siluer sounding instruments did meet

With the base murmure of the waters fall:

The waters fall with difference discreet,

Now soft, now loud, vnto the wind did call:

The gentle warbling wind low answered to all. (II.xii.71.1-9)

This is sensuality in action, the power of concupiscence at work, the sexual act of Acrasia, "greedily depasturing delight" (II.xii.73.4), and "[q]uite molten into lust and pleasure lewd", rendered as an aesthetic construct, a parody of the kind of internal order and harmony that temperance brings to the soul described by Berger and Josef Piper (Berger 61). Guyon, I am arguing, in whom the "secrete signes of kindled lust" (II.xii.68.6) have already appeared, is drawn further into the Bower to visualise and vicariously experience the act of lovemaking on one level, while a fiction of nonengagement with the sensuous environment is maintained on another. He, like the rose, has begun peeping forth with "bashfull modestee" (II.xii.74.5), and now through sight and sound experiences the "bared bosome" shown with "broad display" (II.xii.74.8). The singer of the Carpe Diem song argues: "Gather therefore the Rose of loue, whilest yet is time, / Whilest louing thou mayst loued be with equall crime" (II.xii.75.8-9). Spenser then describes the "constant payre" of the Palmer and Guyon who "swarued not" (II.xii.76.4-5), but keep their forward way towards the reform of the fallen lovers. But then it seems that this forward way is far from straightforward, but involves a more circuitous path "[t]hrough many couert groues, and thickets close," (II.xii.76.6) until they find the place that "did at last display / That wanton Lady" (II.xii.76.7-8). There is also some Spenserian ambiguity when the "noble Elfe" and "carefull Palmer" draw close to the disarrayed Acrasia and her sleeping swain "minding nought, but lustfull game" (II.xii.81.1-2): it is not entirely clear who is not minding what. The apparently self-controlled Palmer and Elfe are not as disentangled from this self-absorbed love play as the surface narrative suggests. And 
this is the problem of the concupiscence that cannot be entirely extirpated even in the regenerate.

Neverthless Verdant and Acrasia are eventually restrained "[i]n captiue bandes" (II.xii.82.5), and Verdant is almost immediately released, and instead (and the use of the pronoun is ambiguous and could also apply to Guyon) "counsell sage in steed thereof to him applyde" (II.xii.82.9). The release of Verdant and his counselling leads immediately to Guyon's suddenly released righteous anger. And so we return to the violent language of the Easter homily. What has to be broken is the seductive spell of the Bower, and for Guyon, perhaps, I am arguing, as well as for Verdant.

Their groues he feld, their gardins did deface,

Their arbers spoyle, their Cabinets suppresse,

Their banket houses burne, their buildings race,

And of the fayrest late, now made the fowlest place. (II.xii.83.1-9)

As the Palmer and Guyon retrace their steps with the "sorrowfull and sad" (II.xii.84.2) Verdant and Acrasia, they come across the wild beasts that had "rag'd with furie mad" (II.xii.84.5), and whose anger is now revived with the desire to release their mistress Acrasia. Even when transformed back from beasts to men, they "did vnmanly looke, / And stared ghastly, some for inward shame, / And some for wrath, to see their captiue Dame" (II.xii.86.3-5). Guyon's pronouncement on Gryll has been seen to represent, as we have seen, the non-elect, the reprobate whose very reprobation shows that they had not had access to the action of grace. But the reference to "the mind of beastly man" may be more universal.

Saide Guyon, See the mind of beastly man,

That hath so soone forgot the excellence

Of his creation, when he life began,

That now he chooseth, with vile difference,

To be a beast, and lacke intelligence. (II.xii.87.1-5)

Guyon's tone is very close to that of the Easter homily:

For what shall it auaile vs (saith Saint Peter) to bee escaped and deliuered from the filthinesse of the world, through the knowledge of the Lord and Sauiour Iesus Christ, if wee be intangled againe therewith, and bee ouercome againe? Certainly it had beene better (saith hee) neuer to haue knowne the way of righteousnesse, then after it is knowne and receiued, to turne backe againe from the holy Commandement of GOD giuen vnto vs. For so shall the 
prouerbe have place in vs, where it is said: The dogge is returned to his vomit againe and the Sowe that was washed, to her wallowing in the mire againe.

(Of the Resurrection Pt 2)

The problem of temperance in its Christian form, of a combat against innate concupiscence, lies in the fact that battling against concupiscence must always involve some form of engagement with it. And if such concupiscence always remains "yea in those who are baptised," as the article of faith of the Elizabethan Settlement has it, then the entanglement of struggling against this corruption of the will can ultimately be won only in death. The destruction of one occasion to concupiscence that the Bower represents will not suffice.

\section{Revenge and fallen human nature in Hamlet}

Hamlet is in one sense a straightforward revenge tragedy, its ghost asking for an actual act of revenge for the actual murder of an actual father. But its archetypal associations also invite a reading of the play in terms of the poison received by the inheritance of our father Adam of the Elizabethan Easter homily, and the injunctions of this homily to kill and offer up the worldly and earthly affections of the body. The end of the play in this sense re-enacts the tragedy of Mordant and Amavia, with everyone dying of the delayed action of the poison of knowledge of inherited sin. All die from actual poison, Gertrude from the poison of the cup, Hamlet and Laertes from the poisoned bait on the duelling foil, and Claudius from both. Each of these poisonings is associated with revelatory knowledge. As Gertrude proclaims to contradict Claudius's "she sounds to see them bleed": "No, no, the drink, the drink O my dear Hamlet - / The drink, the drink - I am poisoned" (5.2.289-90), her appeal to her son suggests her understanding of the justice of his claims about her husband. Laertes discovers he too is poisoned by his own trap for Hamlet and proclaims himself "justly killed with mine own treachery" (5.2.287). And Hamlet executes a revenge that is finally made possible by the absolute knowledge of Claudius's treachery given by Gertrude and Laertes, a knowledge brought with his own death. Claudius, Laertes claims, is "justly served" because it is "a poison tempered by himself" (5.2.306-7). The wordplay with "tempering" argues that the poison is in some way intrinsic to Claudius, that his inner nature is in the mix, that he is figuratively as well as literally the source of the poisoning of the state. There is in this final scene a strong sense that death and knowledge of evil are in some way simultaneous. 
"O proud death," proclaims Fortinbras coming in to this scene of assembled poisoned bodies, "What feast is toward in thine eternal cell / That thou so many princes at a shot / So bloodily hast struck?" (5.2.343-6), as the entire dynasty, including an adopted "brother" Laertes, lies dead from the same poison. In Spenser's allegory of Mordant and Amavia the two figures later become one "senceless tronck", that from the contagion "direful deadly stonck" (II.ii.4.8-9). Fortinbras enters a scene of carnage in which the bodies, already linked verbally through Hamlet's wordplay on Claudius and Gertrude being one flesh, are similarly one in death.

That knowledge of human frailty and poisoning are simultaneous acts is also strongly suggested in the ghost's recalling of his murder. The parallels between this retelling and the description of the deaths of Mordant and Amavia are too close to avoid, once the archetypal association of poison with concupiscence and the Old Adam in human nature has been established, and Old Hamlet's death is seen in this sense as a re-enactment of the Fall. Old Hamlet, sleeping in his Eden-like orchard, is in a state of obliviousness to both the infidelity (whether current or to come is never resolved by the play) of his wife, and the covetous and murderous nature of his brother. He is also, it seems, oblivious to his own sinfulness, his gluttony (as Hamlet later describes it, he is taken "full of bread") and sloth. Both burst in on him with the act of poisoning. He was, he tells Hamlet, "[c]ut off even in the blossoms of my sin, / Unhouseled, disappointed, unaneled; / No reckoning made, but sent to my account / With all my imperfections on my head" (1.5.76-9). The ghost also portrays the seduction of Gertrude in language very like Spenser's descriptions of the seductive witch Acrasia, who Circe-like turns men into beasts. Claudius is a sort of Acrasia in Old Hamlet's denunciation of him: "that incestuous, that adulterate beast, / With witchcraft of his wits, with traitorous gifts - / O wicked wit and gifts that have the power / So to seduce - won to his shameful lust / The will of my most seeming virtuous queen" (1.5.42-46).

Gertrude then becomes the Acrasia figure, identified by the ghost with a personified "lust" in contrast to a personified "virtue." The discourse has moved to something like a morality play: "But virtue as it never will be moved, / Though lewdness court it in a shape of heaven, / So lust, though to a radiant angel linked, / Will sate itself in a celestial bed, / And prey on garbage" (1.5.53-7). It is easy, in fact, to overlook the full force of Old Hamlet's disgust at his wife, who has thus become "lust" in his eyes. The mingling of purity and beauty, and the corruption of lustful feeding in old Hamlet's essentially hideous portrayal of the inexorable action of 
concupiscence has parallels in the descriptions of Acrasia's Bower. Here we have descriptions of the men transformed into beasts: "Now turned into figures hideous, / According to their mindes like monstruous" (II.xii.85.1-5); of the satiated and sleeping Verdant, who, "in lewd loues, and wastfull luxuree, / His dayes, his goods, his bodie he did spend: / O horrible enchantment, that him so did blend" (II.xii.80.79); and of the enchantress Acrasia herself, laid upon a bed of Roses, "as faint through heat, or dight to pleasant sin" (II.xii.2); who hangs over Verdant, "greedily depasturing delight", until she "through his humid eyes did sucke his spright, / Quite molten into lust, and pleasure lewd" (II.xii.73.1-9).

The archetypal aspects of Old Hamlet's report extend to his description of Claudius as serpent: "The serpent that did sting thy father's life / Now wears his crown" (1.5.39-40). This serpent seduces the pure wife, and so the parallel to the corruption of Eve in the Garden of Eden could not be more explicit. Old Adam is poisoned by concupiscence, his wife becomes an ally of the corrupting Satan, he becomes aware of his sinful nature, innocence is lost, and death comes into the world. The ghost's description of the effect of the poison itself has two parallels in $F Q$ II. The first is the description of Maleger, associated by some commentators, as we have seen, with the Pauline Body of this Death.

As pale and wan as ashes was his looke,

His body leane and meagre as a rake,

And skin all withered like a dryed rooke,

Thereto as cold and drery as a Snake,

That seemd to tremble euermore, and quake:

All in a canuas thin he was bedight,

And girded with a belt of twisted brake,

Vpon his head he wore an Helmet light,

Made of a dead mans skull, that seemd a ghastly sight. (II.xi.22.1-9)

The second is the description of the bodies of Mordant and Amavia (already cited), now one "senceless tronck" in whose blood Ruddymane has dipped his hands, thus gaining symbolically the taint of original sin:

... the charme and veneme, which they dronck,

Their blood with secret filth infected hath,

Being diffused through the sencelesse tronck,

That through the great contagion direful deadly stonck. (II.ii.4.6-9) 
Similarly, when Claudius pours his both literal and metaphorical poison into the porches of Old Hamlet's ear, a rapid corruption follows, as the poison, the ghost explains,

Holds such an enmity with blood of man

That swift as quicksilver it courses through

The natural gates and alleys of the body,

And with a sudden vigour it doth posset

And curd, like eager droppings into milk,

The thin and wholesome blood. So did it mine,

And a most instant tetter barked about,

Most lazar-like, with vile and loathsome crust,

All my smooth body. (I.5.65-73)

The suddenness of the translation of poisonous knowledge into death is seen in the moment of Mordant's drinking from his poisoned cup, and its charm, which deceives Mordant at the moment of his apparent restoration by Amavia:

Which when the vile Enchaunteresse perceiu'd,

How that my Lord from her I would repriue,

With cup thus charmd, him parting she deceiud;

Sad verse, giue death to him that death does giue,

And losse of loue, to her that loues to liue,

As soone as Bacchus with the Nymphe does lincke:

So parted we, and on our iourney driue,

Till comming to this well, he stoupt to drincke:

The charme fulfild, dead suddeinly he downe did sincke. (II.i.55.1-9)

As we have seen, Carol Kaske (93) reads this episode in Spenser in terms of the negative suggestibility of Romans 7. It is this suddenness of the fulfilment of a predetermined charm that we see in the poisonings both of Old Hamlet, at his moment of revelatory knowledge, and of his dynasty at the end of the play. Behind the knowledge of Claudius's direct wickedness, then, there seems also to lurk in Hamlet a more universal understanding of the innate corruption of original sin (which, Old Hamlet is more than hinting, Claudius represents), and which cannot ultimately be escaped.

Reading these moments of poisoning in Hamlet against the poisoning of knowledge of $\sin$ in $F Q I I$ opens up a way of seeing the world of the court of Elsinore as one limited to an understanding of morality in terms of the Mosaic Law, rather than New 
Testament hope and the promise of spiritual renewal. Whether the ending of the play portrays Hamlet as one open to redemption or not has been one of the central theological issues in Hamlet interpretation. To see Hamlet's end in terms of Augustinian negative suggestibility, and the knowledge of sinfulness that brings spiritual death, adds a useful dimension to this aspect of criticism of the play, because it explains how Hamlet can be seen at the same time both hardening into a form of sinful action that replicates that of Claudius (the stabbing through the arras and the calculated sending of Rosencrantz and Guildenstern to their executions), and can also be coming to a closer understanding of the nature of divine providence. Amavia was initially able to change Mordant to a better will through a process of moral correction. But then, in contact with the waters of a pure spring, he relapses to sudden death. Something similar is happening to Hamlet, torn between his desire for revenge and his incipient understanding of a higher order in which "there is a special providence in the fall of a sparrow." It is as if, as soon as Claudius's sinful treachery is made explicit through the testimony of its victims, its poison also takes effect on Hamlet, and he is seduced into an act of revenge that replicates rather than redeems the original act of murder.

That Elsinore represents the fallen world and its court, the fallen human condition, in an archetypal way, is suggested from the beginning of the play, and gives resonance to Hamlet's self-styling as a scourge and minister who should in some way redeem the innate human condition. One of the problems with this sort of reading is disentangling what is a self-styling and what a deeper thematic concern of the play. We should not underestimate the extent and murkiness of Hamlet's justifications for revenge. On the other hand, I would argue that reading Hamlet against FQII makes it clear how systematically the same set of notes of fallen human nature, innate corruption, and the seductive nature of concupiscence are developed across characters and scenes, and almost independently of the needs of characterisation and the development of the action. The beginning of the play establishes the murkiness of the fallen world. It is the dead of winter on the battlements; the soldiers cannot see each other, and must struggle to discover each other's identities. By line 9, Francisco has also revealed that he is "sick at heart." At the end of the scene, Marcellus sets out a condition of "wholesomeness" against which the unwholesomeness of a night in which ghosts are walking can be measured.

Some say that ever 'gainst that season comes

Wherein our Saviour's birth is celebrated,

This bird of dawning singeth all night long, 
And then, they say, no spirit dare stir abroad,

The nights are wholesome, then no planets strike,

No fairy takes, nor witch hath power to charm,

So hallowed and so gracious is that time. (1.1.158-164)

The calm of this speech has an immediately redemptive effect. It brings in the dawn to the dark world of the night, a lightening of the hills that is also a lightening of the spirit. "But look, the morn in russet mantle clad / Walks o'er the dew of yon high eastward hill" (1.1.66-7). Two archetypal extremes underpinning the play are thus presented at either end of its first scene. On the one hand, there is a dark night when identity is uncertain, doubt is the key note, the parts of the body stand in need of protection, fortification and healing, the walking of ghosts argues the material hoarding of avarice, the times can be compared with those when Roman portents of disaster are announced, and rumours of preparation for war are based on the replaying of archetypal single combat. All suggest the conditions of a fallen world, a world that, however, the end of the scene suggests is redeemable, if the hope of the nativity can be applied to it. Yet near the opening of the next scene there is a parodic word play by Hamlet on "son" and "sun" that mocks the redemptive hope of Horatio's humble imagery of sunrise, and gives it a bitter taste.

For Hamlet, all the uses of the world are "weary, stale, flat and unprofitable" and the world itself is an unweeded garden " $[\mathrm{t}]$ hat grows to seed, things rank and gross in nature / Possess it merely" (1.2.133-7). Hamlet's mother is herself (in imagery that conveys at once a tender closeness and a more repulsively clinging and concupiscent nature) a parasitic weed; she would hang on Old Hamlet "[a]s if increase of appetite had grown / By what it fed on" (1.2.144-5). The world is fallen, and Hamlet's mother is both innately, and in the act of a second marriage to a husband's brother, directly fallen. The next scene moves to Ophelia, Laertes and Polonius, but continues Hamlet's imagery and, to return to the point just made, creates a seamless progression that is not entirely accounted for by characterisation. Laertes concedes that currently "no soil nor cautel doth besmirch" (1.3.15) the virtue of Hamlet's will, but argues that both personally and politically Hamlet's will cannot continue to remain under his own control. He will fall, and so Ophelia must not "[her] chaste treasure open / To his unmastered importunity" (1.3.31-2). Laertes then delivers his cliched precepts, ones that continue the thematic view of the fallen world as a decaying garden. 
The chariest maid is prodigal enough

If she unmask her beauty to the moon.

Virtue itself scapes not calumnious strokes.

The canker galls the infants of the spring

Too oft before their buttons be disclosed,

And in the morn and liquid dew of youth

Contagious blastments are most imminent.

Be wary then, best safety lies in fear:

Youth to itself rebels, though none else near. (1.3.36-44)

Like the description of an apparently temperate universal harmony (already discussed) in the Bower of Bliss that evokes the sexual act, Laertes' formulaic imagery also conveys his own murky preoccupations with the "liquid dew of youth" and youth that "to itself rebels, though none else near," with a transparency that leads to Ophelia's rebuke not to "[s]how me the steep and thorny path way to heaven, / Whiles like a puffed and reckless libertine / Himself the primrose path of dalliance treads, / And recks not his own rede" (1.3.47-51). That "best safety lies in fear," will become translated in subsequent scenes into Hamlet's direction of Ophelia to a nunnery as the safest course of preservation from innate concupiscence. But before this, Hamlet considers the nature of innate corruption itself. (That this speech is in Quarto 2 not in the Folio is tantalising, and it is tempting to see in it elements of a philosophical superstructure for the play). In considering the hypothetical nature of an innate flaw that might break down "the pales and forts of reason" (1.4.28), Hamlet is exploring in this extremely conditional way (and one where the conditions do not somehow personally touch him) what it means for virtue to be overcome.

The initial analogy is with the reputation of the state, and sets up, importantly, the idea that ridding the state of Claudius rids it of its source of inner corruption, although the corruption must also have arisen from Hamlet's father if the firing off of cannons to accompany drinking is "a custom / More honoured in the breach than the observance" (1.4.15-16). And this unacknowledged reality, that if flamboyant drunkenness was a characteristic of his forebears he might also not escape it, may also underlie Hamlet's apparently detached concern with innate flaws and loss of reputation as a hypothetical problem.

So, oft it chances in particular men,

That for some vicious mole of nature in them,

As in their birth, wherein they are not guilty, 
Since nature cannot choose his origin,

By their o'ergrowth of some complexion,

Oft breaking down the pales and forts of reason,

Or by some habit that too much o'erleavens

The form of plausive manners - that these men,

Carrying I say the stamp of one defect,

Being nature's livery or fortune's star,

His virtues else be they as pure as grace,

As infinite as man may undergo,

Shall in the general censure take corruption

From that particular fault. The dram of eale

Doth all the noble substance of a doubt

To his own scandal. (1.4.23-38)

Hamlet is concerned with one small fault destroying the reputation of a good man, just as the ostentatious drinking of the court destroys Danish credibility as a nation, but he is also preoccupied with whether such faults come from a "vicious mole of nature" or "by some habit that too much o'erleavens / The form of plausive manners". Behind this lies the concern with whether such a "vicious mole of nature" is fixable. And behind this lurks the problem of his mother's, uncle's, father's and his own faults as having the same inherited sources.

On cue, as an answer to this concern about innate and inherited faults, the ghost appears. His "canonized bones" have "burst their cerements" (1.4.47-8), and so although the ghost comes in armour he also comes, metaphorically at least, trailing grave clothes like Spenser's Maleger (“of such subtile substance and vnsound, / That like a ghost he seem'd, whose graue-clothes were vnbound" (II.xi.20.8-9)). In Canto XII of the Faerie Queene, and as already discussed in terms of self-knowledge, the false genius is compared to the true Genius who is our "Selfe" and "who wondrous things concerning our welfare, / And straunge phantomes doth lett vs ofte forsee, / And ofte of secret ill bids vs beware" (II.xii.47.5-7), while the false genius "secretly doth vs procure to fall, / Through guilefull semblants, which he makes vs see" (II.xii.48.5-6). Hamlet's first concern is which type of ghost this is, one that will bid him beware of secret ills, or one with wicked intent. In either case, the ghost is an invitation to hybris, to "thoughts beyond the reaches of our souls" (1.4.56). For Horatio, the possibility that the ghost will through false semblants secretly procure Hamlet to fall, leads almost immediately to the danger of madness. When Hamlet “waxes desperate with imagination" (I.4.87), we are also reminded of Spenser's 
Phantastes in the first turret of the House of Alma, with his " $[\mathrm{b}] \mathrm{ent}$ hollow beetle browes, sharpe staring eyes, / That mad or foolish seemd" (II.ix.52.6-7). Spenser's Phantastes' room buzzes with his collection of "idle thoughts and fantasies, / Deuices, dreames, opinions vnsound, / Shewes, visions, sooth-sayes, and prophesies; / And all that fained is, as leasings, tales and lies" (II.ix.51.6-9). The ghost itself may be a vision that inspires helpful insight beyond the normal reaches of human souls, or it may unleash an unbalanced condition of the mind where fantasy or imagination dominates reason. What the ghost also brings with it, along with its trail of grave clothes, is the sins of which it is being purged, the "foul crimes done in my days of nature" (1.5.12).

By the end of Act One we have encountered the dangers of concupiscence, drinking, gluttony, sloth, curiosity for prohibited knowledge, accusations of adultery and murder and injunctions to revenge. Archetypes of original sin are the logical extension of such a survey. Old Hamlet is murdered in his orchard and a serpent stings his life. As the murder is committed in the ghost's word by "that incestuous, that adulterate beast", the Old Testament archetype of adultery as idolatry or "fornication against God" (or more vividly in the King James translation of Psalm 72, "a-whoring away from God"), is brought to mind, as it must also be in the story of Mordant's straying with Acrasia.

The ghost has also given Hamlet an impossible injunction. Hamlet should not "[1] et...the royal bed of Denmark be / A couch for luxury and damned incest" (1.5.82-3). Hamlet must address and remove "lust." The ghost has given Hamlet an open brief "howsomever thou pursues this act" - but the ghost had also enjoined him to "taint not thy mind" (1.5.84-5). Having been given these two intrinsically opposed injunctions, Hamlet is immediately if unconsciously concerned with the problem of sudden internal disintegration: "Hold, hold, my heart, / And you my sinews grow not instant old / But bear me stiffly up" (1.5.94-5), as if his body and mind have in fact been tainted. It is again a moment of sudden corruption by knowledge. The ghost's revelation is, in little, a loss of innocence that parallels the Fall. And Hamlet sees himself in an archetypal way. It is not just a local matter of restoring a just succession to Denmark and finding justice for his father's murder, or executing this justice himself, that is at issue. More grandly, "[t]he time is out of joint: O cursed spite, / That ever I was born to set it right" (1.5.18990), as if Hamlet can single-handedly redress the effects of a disruption to the cosmic order of the type caused by the Fall. 
The first Act of Hamlet ends with the swearing of oaths, just as the first Canto of $F Q I I$ ends with the swearing of a solemn oath. Guyon's oath, which follows a mysterious meddling of blood and earth and hair then thrown into the grave, and which he "gan deuotely swear", mentions vengeance. The oaths at the end of Act One are for the silence of the watchmen. Hamlet wants knowledge from the ghost, so that "with wings as swift / As meditation or the thoughts of love" (1.5.29-30) he may sweep to his revenge; he wants to keep his mind pure and " $[\mathrm{u}] \mathrm{nmixed}$ with baser matter" (1.5.104), so that he can respond to the ghost's final injunction, "[r]emember me" (1.5.91). But he is almost immediately concerned with the corruption of memory, itself a sign of the Fall, and reaches for an aid to memory: "meet it is I set it down" (1.5.107). It is only when it is written that he can say: "It is 'Adieu, adieu, remember me.' / I have sworn't" (1.5.111-12).

After burying Mordant and Amavia, Guyon takes up the Ruddymane, the innocent Babe who smiles on Guyon. The Babe's innocence is what Guyon, through his encounter with the poisoned Mordant and suicide Amavia, has lost. Guyon's grief over the Babe's innocence is portrayed as a wounding act of pity: "ruth emperced deepe / In that knightes hart" (II.ii.1.9). He then delivers a speech over the Babe that portrays the human condition as a vale of tears, without any hope.

Ah lucklesse babe, borne vnder cruell starre,

And in dead parents balefull ashes bred,

Full little weenest thou, what sorrowes are

Left thee for porcion of thy liuelyhed,

Poore Orphane in the wide world scattered,

As budding braunch rent from the natiue tree,

And throwen forth, till it be withered:

Such is the state of men: Thus enter we

Into this life with woe, and end with miseree. (II.ii.2.1-9)

Attempting to wash the Babe's hands, he cannot get them clean, and this is usually read as a sign of the innate condition of original sin. Guyon's view of the condition of humanity, that we enter "life with woe, and end with miseree," is completely contrary to Christian redemption, which overturns such misery through the hope of a future life.

Guyon's set speech over Ruddymane is paralleled in Hamlet's famous set speech on the nature of the world. The knowledge that has come to Hamlet through the ghost, which like the deaths of Mordant and Amavia has destroyed any hope of an innocent and secure parentage, has tainted his view of the nature of the world 
itself. Although he can convey a view of a beautiful world and a noble human nature, he can no longer emotionally identify himself with such a view. There is of course a range of ways this speech can be delivered, including a consciously self-parodying one, and it is delivered for a particular strategic effect. But it still brings to this moment of the play a view of fallen physical and human nature not unlike Guyon's despair over the Babe:

this goodly frame, the earth, seems to me a sterile promontory; this most excellent canopy the air, look you, this brave o'erhanging firmament, this majestical roof fretted with golden fire - why, it appeareth no other thing to me but a foul and pestilent congregation of vapours. What a piece of work is a man! How noble in reason, how infinite in faculties, in form and moving how express and admirable, in action how like an angel, in apprehension how like a god! The beauty of the world, the paragon of animals - and yet to me, what is this quintessence of dust? (2.2.282-90)

Man delights not Hamlet, and that women delight him not (although this quickly becomes a form of boys' joking interplay) is central to the action with Ophelia, and is a direct result of his view of humanity as irrevocably tainted, despite the injunction of the ghost that he should "taint not his mind." The genie of the idea that humanity is not always noble cannot be put back in the bottle.

\section{Tainted youth}

And so we progress to the ways young men can become "tainted." A somewhat cynical view of the inevitable fall of the young courtier to pleasure is established at the opening of Act Two. Polonius, beginning the play's themes of spying and entrapment, wants Reynaldo to pretend that Laertes is guilty of "such wanton, wild, and usual slips / As are companions noted and most known / To youth and liberty" (2.1.22-4). Reynaldo is not to go to the extreme that might suggest Laertes is "open to incontinency" (2.1.30). But his faults may seem "the taints of liberty, / The flash and outbreak of a fiery mind, / A savageness in unreclaimed blood, / Of general assault" (2.1.30-4). Reynaldo can lay these "slight sullies" (2.1.39) on Laertes in others' hearing. A list is given, including gaming, drinking, fencing, swearing and quarrelling, to which Polonius adds "drabbing", but Reynaldo then draws back: "My Lord, that would dishonour him" (2.1.27), and so we get some sense of the limits of what is socially acceptable high spirits for the noble Danish visitor to Paris and his Elizabethan equivalent, and what falls into the apparently more serious category of "incontinency". Laertes can indulge in some "taints of liberty," as long as he does 
not go too far. Hamlet, by contrast, in Polonius' view, bursting in on Ophelia, seems to be falling under the "very ecstasy of love, / Whose violent property fordoes itself, / And leads the will to desperate undertakings / As oft as any passion under heaven / That does afflict our natures" (2.1.100-4). Both forms of falling away from some state of innocent sinlessness, those of Hamlet and those of Laertes, are apparently still in the incipient stage.

Hamlet's despair over man's status as a "quintessence of dust" takes a more fully shaped form in his attack on Ophelia. Although he himself is "indifferent honest" (3.1.120), he is also "proud, revengeful, ambitious" (3.1.120-2), and with a range of potential other offences just a call away. It would have been "better my mother had not borne me" (3.1.121). As with Guyon's view of the state of men, "thus enter we / Into this life with woe, and end with miseree", Hamlet identifies himself with a generalised crabbed and pointless human existence: "What should such fellows as I do crawling between earth and heaven?" (3.1.125). This leads to the central attack on Ophelia, the admonition to go to a nunnery. Because "virtue cannot innoculate so our old stock but we shall relish of it" (3.1.116-7), no-one should be a "breeder of sinners" (3.1.119-20). Corruption will always win over attempts to reform: "the power of beauty will sooner transform honesty from what it is to a bawd, than the force of honesty can translate beauty into his likeness" (3.1.111-3). A fear about himself, and the ease of his own potential corruption, becomes the spearhead of his rejection of Ophelia, but as he talks this potential threat seems to become an actual one. If Ophelia were to marry (with the subtext of, say someone like me, Hamlet) she would "not escape calumny" (3.1.132-3). And finally she is accused of being actively involved in the kinds of seductions that will undo a young man's tender defences: "I have heard of your paintings too, well enough" (3.1.137), and so on. Ophelia could become Hamlet's Acrasia as Claudius is the Acrasia of Old Hamlet's Gertrude. Claudius wins Gertrude, according to the ghost (for no other explanation is possible for the ghost), "with witchcraft of his wits, with traitorous gifts" (1.5.43). Ophelia has the potential to attack Hamlet's defences with makeup, lisping, nicknaming God's creatures (using forms of gentle deception not unlike those of Spenser's Phaedria), and so a gentle poison that could nevertheless lead him astray. It is clear, however, that it is of his own nature that he is essentially afraid. 


\section{The bosom "black as death"}

The imagery of concupiscence and corruption accumulates in a similar way to the imagery of concupiscence and corruption in FQII. When Claudius is brought to the point of confession by the Mousetrap play, he proclaims his sin is rank and smells to heaven and "has the primal eldest curse upon't, / A brother's murder" (3.3.37-8), and so he is "a limed soul that struggling to be free / [Is]...more engaged" (3.3.68-9). His bosom is "black as death" (3.3.67). As all the imagery of decay culminates in the feculent dark waters of the Cave of Mammon in Spenser, Claudius takes at this point all the blackness and rankness of human sinfulness to himself. At this point he attempts to pray.

Hamlet's rationale for not killing Claudius at this point is complex. It probably amounts to a kind of bad faith, a rationalisation for not executing a murder when he still has underlying doubts about his justification for the act, and when he knows at heart that the act of revenge is itself a sin. His spoken justification, however, is as black as it could be in Christian terms, and just as Claudius seems about to open himself to Christian redemption, Hamlet closes the gate on such redemption for himself by wishing to execute a revenge that will deny such redemption to another. It is hard in fact in any objective way to distinguish the blackness of the intentions of uncle and nephew at this moment, but if anything in Christian terms the one who would deny Christian redemption to another must be blacker than the one who is struggling to find his way towards it. Hamlet has only just ruled out the extremes of irascibility in his upcoming interview with Gertrude; he will "speak daggers to her but use none" (3.2.357), even though he could "drink hot blood, / And do such bitter business as the day / Would quake to look on" (3.2.3513). He will rebuke only with words. But Claudius, it seems to Hamlet, in praying for redemption is pre-empting Hamlet's role as "scourge and minister." How will Hamlet actually be revenged if he decides to take Claudius "in the purging of his soul, / When he is fit and seasoned for his passage?" (3.3.85-6). And what sticks in Hamlet's throat is that his own father was taken "grossly, full of bread, / With all his crimes broad blown, as flush as May" (3.3.80-1). He wants then to murder Claudius when Claudius is "about some act / That hath no relish of salvation in't” (3.3.91-2).

This speech cannot be seen as neutral in terms of the events of the play, as not without direct harm. When Hamlet shortly afterwards hears a noise behind the arras he acts immediately thinking it is the King and presumably a Claudius now caught in an act of spying, an act that "hath no relish of salvation in't." Hamlet has, in effect, at 
the moment of not murdering Claudius at prayer, given himself prior permission to murder when the occasion is more appropriate to his purposes. The motivation of the "purging" of the kingdom has in this case become murky indeed. And part of what must be suggested here is the inheritance of the Fall. The primal murder of Abel by Cain brought murder and violent death into the world, and Hamlet is no more able to escape this inheritance than Old Hamlet was with Old Fortinbras, or Claudius with Old Hamlet.

Claudius does not, as it turns out, have access to grace. But the deep irony of the play is that his apparent potential access to grace becomes the fulcrum from which Hamlet's actions will now swing to the execution of others - first Polonius, and then Rosencrantz and Guildenstern. Claudius, also ironically, in turn now sees his own motivations in terms of scourging. Hamlet cannot be directly acted against, because Hamlet is "loved of the distracted multitude, / Who like not in their judgement, but their eyes; / And where 'tis so, th'offender's scourge is weighed, / But never the offence" (4.3.4-7). Claudius is now Hamlet's "scourge". And Hamlet rages "like the hectic" (4.3.62) in Claudius' blood.

The final act of the play then becomes one of the poisoning and purging of blood, and one in which the common inheritance of the characters becomes most marked. As I have argued, there is a strong sense that when all die of the same poison, it is a poison which, like that of Spenser's Acrasia, has been present from the beginning of the action and has more allegorically come from within. This is seen most clearly when Laertes identifies Claudius as the source of the poison, an attribution which can be read both literally and metaphorically: "[i]t is a poison tempered by himself" (5.2.307). Hamlet administers Claudius's own poison to Claudius in retribution both for murder and for his concupiscent acts of incest. And so both the dialogue and the imagery of the Hamlet invite us to see the play in terms of the concupiscence and original sin that is also the subject of Spenser's work. 


\section{Chapter Five: Suicide and the unfortified heart}

The previous two chapters have established two frames for the examination of temperance in FQII and Hamlet, one originally Greek and one overtly Christian, and has thus made a case for both. But the issue of which frame, classical or Christian, should predominate is more problematic and still not resolved in Spenser or Shakespeare criticism.

In The Analogy of the Faerie Queene James Nohrnberg writes, “Temperance is a classical virtue, and the classical idea of restraint is surely to be understood in relation to classical ethics" (301). More recently, in 2001, in "The Faerie Queene, Books I-III" Suzanne L. Wofford describes FQII as "a book based on a classical virtue, temperance, taken from Aristotle's Nichomachean Ethics and depending on a model of balance that resists completely the near-apocalyptic implications of Book I" (119). Such approaches to temperance as primarily a classical virtue in FQII can be counterbalanced by the theological approaches to temperance offered in the previous chapter.

One way of seeing the opening of $F Q I I$ is that an overtly Christian legend about holiness now gives way to a more secular legend about moral behaviour based in classical ethics, without entirely removing a Christian frame. The shift was described by Woodhouse in 1949 in terms of the distinction between "the order of grace, and the order of nature" (qtd Hamilton 10). It was Melanchthon in particular who applied Luther's distinction between the spiritual and civil to ethical behaviour. As Jill Kraye explains in The Cambridge History of Renaissance Philosophy, Melanchthon thought Christ came to remit sins and deliver the Holy Spirit to those who believed in him, not to teach ethical precepts already available to natural reason and as seen in classical thought (Kraye 323-4). If Spenser follows Melanchthon, the shift from Christian to classical between $F Q$ I and $F Q I I$ is easily understood. But Hamilton also cites Harry Berger, who sees a "shift, marked by the intercession of an angel sent to aid Guyon, from an Aristotelian concept of virtue to a Christian concept" (Spenser 10). This is a different way of seeing the relationship of classical and Christian - it assumes that the classical approach to temperance is insufficient and that Spenser replaces it mid-point in the legend with a better, Christian way of seeing temperance.

The relative importance of classical and Christian points of reference is a longstanding topic in Hamlet criticism, with proponents on either side. To give a few 
representative examples, Robert Miola (1992) pursues the classical, finding echoes of Senecan tragedy in the fabric of the speeches of Hamlet and the themes of Stoic and neo-Stoic thought in its philosophy. Roy Battenhouse (1994) argues for the centrality of the Christian references in the play, finding in "Hamlet's strategy for seeing the world right" a "perverse imitation of the method of Atonement in Christian story" (402). Other commentators acknowledge the Christian references in the play without allowing them to affect a secular or more indeterminate reading. D. Douglas Waters (1994) considers Hamlet a secular tragedy but one in which the Christian setting plays a significant role. For Alan Sinfield (1980), who looks particularly at Stoic and Calvinist treatments of providence, "Christian statements supersede pagan ones in theologically precise form, but the action remains ambiguous" (97). Millicent Bell (2002) finds the scepticism of Montaigne in the play's uncertainties of cause and effect. Hamlet's speech about readiness in the final Act reflects "a kind of stoic fideism" (50).

Another way of approaching this issue is to see the topic of temperance as one that, in the late sixteenth century, naturally invites a debate about the relationship of classical and Christian world views. Spenser and Shakespeare can then be seen as directly foregrounding the similarities and the tensions between systems of thought that can sometimes be reconciled and sometimes cannot.

\section{Conflicts between classical and Christian ethics}

As Jill Kraye's article "Moral Philosophy” explains, there was far from a consensus in the philosophical thought of the Renaissance about how classical thought should be accommodated to or assimilated into Christian thought. The humanist tradition of syncretism generously sees classical thought as prefiguring Christian. Spenser often uses classical imagery to allude to Christian themes. As Bartolomeo Scala (citing Basil) saw it, Christians should take from pagan writers only what is right, like bees selecting from certain flowers (Kraye 319). Those who followed the approach of Luther and Melanchthon preferred to keep the two systems of revelation and reason strictly separated. Others - Matteo Bosso, Lorenzo Valla, Vives and the Calvinist Lambert Daneau - at times argued that Christian thought had completely replaced classical ideas, that classical ethics were based on false premises and corrupt human reason, with the philosophers wandering in the dark making childish errors (Kraye 320-23). 
William Bouwsma in "The Two Faces of Humanism" focuses particularly on the tension between Stoic and Augustinian thought, finding this tension present not only between different writers of the Early Modern period but also within the work of its writers, including Calvin. Part of the conflict between Stoicism and Augustinianism resides in the relative emphasis placed on reason or the will, the head or the heart (the Augustinian "cor"). For the Stoic, virtue is possible when reason, through an obedient will, controls the body and its passions. The body is intrinsically inferior to the soul, which alone can achieve immortality. For Augustine human reason is not divine. Knowledge of God comes through the Scriptures. The heart plays a more central role; the will is not an intrinsically obedient servant of the reason and the body and its passions are accorded more respect (Bouwsma 26).

One area where the historical distinction between Christian and Stoic thought is particularly stark is on the topic of suicide. In The City of God XIX, Augustine uses the Stoic case for suicide as a weapon to attack the premises of classical ethics. In Augustine's argument the Christian sees the world as intrinsically miserable, but through "true piety" and faith and hope in the world to come they may still be happy because they are safe in the promise of eternal salvation. The classical philosopher believes that the ultimate happiness of life is virtue and can be achieved through virtuous behaviour, particularly the cardinal virtues of prudence, justice, fortitude and temperance. Augustine argues this means the classical philosopher sees human life as essentially happy. But if this is the case, Augustine thunders in an attack on Stoic views of fortitude, how can the philosophers also argue for the option of suicide if life becomes too miserable? It is also, for Augustine, deeply presumptuous to see virtue as the ultimate happiness. Salvation is the ultimate happiness, and this point underlies subsequent Protestant theology.

The efficacy of all the cardinal virtues for Augustine (centrally "that virtue which the Greeks call sophrosyne, and we temperance, and which bridles carnal lusts, and prevents them from winning the consent of the spirit to wicked deeds" (511; XIX. 4)), lies in a proper relationship to God. And this proper relationship with God, rather than a classical virtue based primarily on reason, is the basis both of the cardinal virtue of justice, and of virtue itself: "There is in man himself a certain just order of nature, so that the soul is subjected to God, and the flesh to the soul, and consequently both soul and flesh to God." In this manner Augustine makes the classical cardinal virtues Pauline. "For the soul is so much less subjected to God as it 
is less occupied with the thought of God; and the flesh is so much less subjected to the spirit as it lusts more vehemently against the spirit" (512; XIX.4).

Calvin also uses the ideal of Stoic fortitude as the focus of an attack on Stoic philosophy, comparing it adversely with Christian patience:

You see that to bear the cross patiently is not to have your feelings altogether blunted, and to be absolutely insensible to pain, according to the absurd descriptions which the Stoics of old gave of their hero as one who, divested of humanity, was affected in the same way by adversity and prosperity, grief and joy; or rather like a stone, was not affected by anything...But we have nothing to do with that iron philosophy which our Lord and Master condemned - not only in word, but also by his own example. For he both grieved and shed tears for his own and others' woes. (Calvin2, 2; III.viii.9)

It is such attacks that place the conflict between Stoic and Augustinian thought, and classical and Christian thought more generally, not in the past but in the present in Early Modern thought.

\section{Temperance in early Stoic and Augustinian thought}

Spenser's focus on temperance in FQII, especially in the early cantos, places the tensions between Stoic and Augustinian thought under a magnifying glass. The importance of voluntarism - the emphasis on the heart and the will over reason and the intellect in Augustine's theology - is particularly apparent in Augustine's central definition of temperance, that in De Moribus Ecclesiae. Here temperance is defined as an act of the heart, "love giving itself entire and incorrupt for God.” Intemperance is associated with the fall of Adam and avarice, along with curiosity as avarice for knowledge.

Temperance is also of considerable importance to Stoic thought. It was Stoicism that had returned the cardinal virtues to a central place in philosophy after Aristotle had widened the number of virtues away from this earlier Platonic grouping. Because in the Old Stoa it was sophrosyne that prevented the passions from gaining control, and so was most important for achieving the summum bonum, the extirpation of all passion, temperance is at the heart of the Stoic system (North 214-5). In Zeno, sophrosyne was identified with the act of choosing the moral virtue that was in accordance with right reason (North 216). It is in other words temperance that has the active agency in reaching the ultimate goal of apatheia.

In the writers of the Old Stoa such as Chrysippus, sophrosyne is strongly prudential; it is the knowledge of things to be chosen or avoided, while its opposite, 
akolosia, is ignorance of things to be chosen and avoided. Eutaxia (proper arrangement), kosmiotes (orderliness) aidemosyne (sense of shame) and enkrateia (self-restraint) are aspects of temperance for Chrysippus, and austeria (severity), euteleia (frugality), litotes (simplicity) and autarkeia (independence) are aspects of temperance for Andronicus. Both follow from a prudential view of temperance (North 216). The role of these aspects of temperance is later seen in Cicero's treatment of temperance as decorum, and here Cicero particularly follows Panateius, for whom sophrosyne arose in the feeling for "order, propriety and moderation" (North 281). Behind this prudential aspect of early Greek temperance lies the view of the Old Stoa, that passion is a mistaken judgment of the ruling element of the soul. In the later Cicero intemperance was the mother of passion.

In Tusculans, Cicero equates the person who is frugi, moderatus and temperans with the sage as one free from distress (North 269). The mind that meditates day and night on the order of the world, and understands its own relationship to this world order, is filled with joy, and the maxim "know thyself" is interpreted in terms of this knowledge. "The orator-statesman cannot achieve perfection without subduing his appetites and subjecting impulse to reason" (270). Thus temperance is essential to the idea of reason as sovereign, to self-knowledge, and to the ordered governance of the state. In Early Modern Stoic thought sovereign reason becomes a path to God. Lipsius argues:

I am guarded and fenced against all external things and settled within myself, indifferent to all cares but one, which is that I may bring into subjection this broken and distressed mind of mine to right reason and God and subdue all human and earthly things to my mind (qtd in Bouwsma 39).

Spenser in FQII and Shakespeare in Hamlet rehearse some intractable conflicts between classical and Christian, Stoic and Augustinian thought, particularly through the topics of suicide and grief.

\section{Suicide and intemperance}

The act of suicide is in one sense an obvious act of intemperance. This was true in the classical world, as is made particularly clear in Virgil's Aeneid, when Dido brings her life to an end in a state of bitterness and irrational furor that is close to complete insanity. But in classical thought, suicide can also be seen as an act of nobility and as the only rational choice in the face of extreme suffering or potential irredeemable ignominy. Suicide is associated with such flawed but acceptable nobility in 
Shakespeare's Roman plays, in the deaths for example of Cleopatra, Mark Antony and Brutus, and it is to such a view of suicide that Horatio refers at the end of Hamlet, when he wishes to style himself as "more an antique Roman than a Dane" (5.2.320), and share Hamlet's death. It is the kind of death that is popularly associated with Stoicism.

When, parting from the Redcrosse Knight, Guyon enters his own story-line in $F Q I I$, he immediately encounters a suicide, Amavia, who exhibits all the characteristics of furor of a Dido, and who sees herself as abandoned by the gods. That Guyon later refers to her "sad Tragedie" reinforces our sense that she is to be seen in classical terms. Her language is worthy of Seneca as she justifies her suicide:

But if that carelesse heuens (quoth she) despise

The doome of iust reuenge, and take delight

To see sad pageaunts of mens miseries,

As bownd by them to liue in liues despight,

Yet can they not warne death from wretched wight.

Come then, come soone, come sweetest death to me,

And take away this long lent loathed light:

Sharpe be thy wounds, but sweete the medicines be,

That long captiued soules from weary thraldome free. (II.i.36.1-9)

Guyon seems to endorse her despair in classical terms, "[a]ccusing fortune, and too cruell fate, / Which plonged had faire Lady in so wretched state" (II.i.56. 8-9).

But these classical connotations are odd for the reader who has previously encountered suicide and despair in strongly Christian terms in FQI.xi. Here the Redcrosse Knight, in despair that his sins have made him unworthy of divine redemption, a despair that follows the deflation of his previous spiritual presumption, encounters a suicide, and is tempted by the allegorical figure Despayre with the following seductive argument:

Is not short payne well borne, that bringes long ease,

And layes the soule to sleepe in quiet graue?

Sleepe after toyle, port after stormie seas,

Ease after warre, death after life does greatly please. (I.ix.40.6-9)

Despayre's argument is that suicide is the only escape for a much deserved divine judgement: "For death was dew to him, that had prouokt Gods ire" (I.ix.50.9). The 
fallacious argument must be countered by Una, who snatches the knife from Redcrosse's hand, with the promise of Christian redemption.

In heauenly mercies hast thou not a part?

Why shouldst thou then despeire, that chosen art?

Where iustice growes, there grows eke greter grace,

The which doth quench the brond of hellish smart. (I.ix.53.4-7)

That in FQII, the Knight of Temperance, far from condemning the act of suicide, commiserates with the suicide herself, "accusing fortune and too cruell fate," must be worrying if suicide is seen in the theological terms established in FQI. But in FQII, Guyon pointedly reserves judgement on this suicide, showing more concern for Amavia's proper burial.

But sith this wretched woman ouercome

Of anguish, rather then of crime hath bene,

Reserue her cause to her eternall doome,

And in the meane vouchsafe her honourable toombe. (II.i.58.6-7)

Guyon has a different solution from Una's words of faith to the problem of Amavia's suicide, a suicide he sees as having been caused "[w]hen raging passion with fierce tyranny / Robs reason of her dew regalitie, / And makes it seruaunt to her basest part" (II.i.57.4-6). Amavia represents a problem not of spiritual despair, but of the inadequacy of "mortalitie, / And feeble nature cloth'd with fleshly tyre" (II.i.57.2-3). At this point, it starts to seem that what is at issue is not an actual suicide, but an allegorical presentation of the internal disintegration of the justice of the self. Guyon offers a solution, not of faith, but of moral behaviour, the solution of temperance. It seems with this solution that we have moved away from the spiritual rules that applied in the allegory of faith of $F Q \mathrm{I}$, and into a world of ethical concerns where a different set of rules apply, those more familiar in classical philosophy such as the ethical mean of Aristotle, suggested by the reference to "measuring out a mean".

But on the other hand, the portrayal of Mordant and Amavia as "the ymage of mortalitie, / And feeble nature cloth'd with fleshly tyre", sounds more Pauline than classical, as does the name Mordant, one who "death does bring." It is puzzling to know now how to read the allegory. The pagan overtones of the burial of Mordant and Amavia do not help this confusion. We seem now to have entered the world of epic, where proper burial is a matter of great importance, as it is in the Aeneid. 


\section{The internal disintegration of the self}

In Platonic and Stoic philosophy, the control of reason was paramount. Guyon's description to the Palmer of Amavia's suicide can be seen in this light.

Old syre

Behold the ymage of mortalitie, And feeble nature cloth'd with fleshly tyre

When raging passion with fierce tyranny

Robs reason of her dew regalitie,

And makes it seruaunt to her basest part:

The strong it weakens with infirmitie,

And with bold furie armes the weakest hart;

The strong through pleasure soonest falles, the weake through smart. (II.i.57.1-9)

In this speech, Guyon conveys an internal disintegration of the self that touches base with all four cardinal virtues. In the Platonic and Stoic systems, reason and the cardinal virtue of prudence is always at the top of the hierarchy. It has "dew regalitie". Temperance, as the control of fleshly desire, is at the bottom of the hierarchy of cardinal virtues. But if temperance fails, "raging passion" will disturb the whole system. The rebellion echoes the potential tyranny of the masses in Plato's Republic (178-180; IV.v.430-432). Reason then becomes "seruaunt" to the "basest part." The consequence of this disruption of the natural governance of reason by raging passion is also to invert the proper functioning of the cardinal virtue of fortitude. And it is this disruption that enables the act of suicide. The "strong," both reason as governor and fortitude as defender of reason, are then weakened "with infirmitie"; they cannot act justly to defend the self. With the self's defences disabled, the passions can now arise to attack it; the "weak hart" is instead armed with "bold furie." What is overturned is the justice of a system that requires reason to rule in its own defence. The problem that faces the Knight of Temperance in FQII is, in this case, the problem of the passions overcoming reason and destroying virtue.

Seen in Augustinian terms, Amavia's suicide is caused both by the weakness of the flesh represented by the wayward Mordant, and by a lack of justice in this self caused by the resulting failure of a just relationship with God. The disorder in the self both produces and results from a lack of faith, as seen in Amavia's despairing accusations that the heavens have abandoned her. And so fortitude becomes a 
homicide in her case; her heart is armed with bold fury, and she takes the path allowed by classical philosophy, but rejected by Augustine.

This Augustinian way of reading the episode is not sanctioned either by Guyon's cheerful pronouncement that measuring out a mean will make man "thrise happy," or by his refusal to judge Amavia's suicide, describing her instead as "ouercome / Of anguish, rather then of crime" (II.i.58.6-7). Both point, rather, to a classical way of reading the episode. But when Guyon takes up the Bloodie babe in his arms at the opening of the next canto with the despairing pronouncement " $[t]$ hus enter we / Into this life with woe, and end with miseree" (II.ii.2.8-9), he seems now to be seeing the world in terms of the Augustinian view of life as intrinsically miserable without faith. "What flood of eloquence," Augustine pronounces, "can suffise to detail the miseries of this life?" (Augustine, City of God, 511; XIX.4).

\section{Iron Stoics and Christian tears}

In Stoic terms, Amavia may be seen to be taking a noble path in the face of irretrievable misery when she "ended all her woe in quiet death" (II.i.56.4). But on the other hand, for the Stoic, grief is one of the perturbations which should be avoided through apatheia, and so Amavia may also be seen to have failed. Amavia is "ouercome with anguish" and is also the "ymage" of another suspect emotion in Stoic terms, "ruefull pitty." Guyon's responses are portrayed in tandem with Amavia's, to the point of complete identification. If he cannot effect relief for Amavia's pain, Guyon promises her "to die with you in sorrow, and partake your griefe" (II.i.48.9). Guyon, in other words, fails miserably to exert Stoic fortitude in the face of grief, and instead appears to be completely captured by emotional excess. As he views the tableau of the fallen family, an internal struggle develops that is won by the (in Stoic terms suspect) "ruth and frail affection," as internal fortitude is overcome.

His hart gan wexe as stark, as marble stone,

And his fresh blood did frieze with fearefull cold,

That all his sences seemd berefte attone:

At last his mighty ghost gan deepe to grone,

As Lion grudging in his great disdaine,

Mournes inwardly, and makes to him selfe mone,

Til ruth and fraile affection did constraine,

His stout courage to stoupe, and shew his inward paine. (II.i.42.2-9) 
Guyon, in other words, goes through a sequence that mirrors the problem he later identifies with Mordant and Amavia. In terms of Stoic apatheia, he has failed in the sophrosyne that prevents the emotions overwhelming inner fortitude. His "stout courage" is forced to "stoupe," just as in his later description of the tableau of Mordant and Amavia, passions weaken the strong with "infirmitie." When Amavia dies the complete identification and anguish are resumed:

good Sir Guyon, could vneath

From teares abstayne, for griefe his hart did grate,

And from so heauie sight his head did wreath,

Accusing fortune, and too cruell fate,

Which plonged had faire Lady in so wretched state. (II.i.56.5-9)

But then Guyon moves from this identification to a complete intellectual detachment. It is as if Guyon with his Palmer at this point demonstrates an ideal Stoic detachment and the ruling control of reason that Amavia lacked. Such Stoic detachment, and not emotional excess, is the desired outcome of temperance.

But such Stoic detachment would not meet with the approval of Calvin, who, as we have seen, compared it adversely with Christian patience. To see Guyon's tears in this more Calvinist and Augustinian light is to read the sequence of Guyon's response to Amavia differently. Guyon's grief over the tableau of Mordant and Amavia, in this case, becomes closer to Christ's tears over Jerusalem, and his mourning as a lion suggests an analogy with the Christ who protects his church. That Guyon's initial goal is to return Amavia to "liuing blood" (II.i.43.5) and "liuing aire" (II.i.43.9), suggests a concern with a spiritual rather than a moral fall. The emphasis on the heart in this narrative also suggests that it is the will rather than reason that is centrally at issue in Amavia's demise.

What is emphasised in the description of Amavia's demise is the damage to the heart. Amavia gives "a grone so deepe and low, / That seemd her tender heart was rent in twaine" (II.i.38.3-4), dying from a knife stuck in her "white alabaster brest" (II.i.39.5), so that the blood pours from "her bleeding hart" (II.i.40.3). In seeing her predicament, Guyon takes on its characteristics. Guyon's heart "gan wexe as starke as marble stone, / And his fresh blood did frieze with fearefull cold" (II.i.42.2-3). Amavia's "frozen hart" (II.i.46.6) has been seized with "stony cold" (II.i.46.5), and as she breathes forth words from her "riuen chest" (II.i.47.5), Guyon is so overwhelmed by her death that "for griefe his hart did grate" (II.i.56.6). What is 
problematic, in that the heart is weak or weakened "with infirmitie" (II.i.57.7), is that it cannot act with the restorative love that characterises Christ's tears. It cannot enact the temperance of "love giving itself entire and incorrupt to God." Instead it reacts destructively, with the "bold furie" (II.i.57.8) of suicide. What must above all be strengthened to restore proper order to the self is the heart.

That the status of Guyon's own heart is at issue is underlined when Guyon picks up the Bloodie Babe, and the wounding of the heart that had been observed in Amavia is now transferred directly to him as "ruth emperced deepe / In that knightes hart, and words with bitter tears did steepe" (II.ii.1.8-9). And Guyon's words are all to do with a feeling of abandonment, with loss of love and self-pity. Seen in the Augustinian way, it is not clear how these "bitter tears" are to be reconciled with the previous confident pronouncement that "temperaunce... with golden squire" (II.i.58.1) can "measure out a meane" (II.i.58.2), and that will make man "[t]hrise happy" (II.i.58.5). And what is also not clear is which of the opposed emphases on head or heart, a Stoic rejection of emotion or Augustinian prioritising of the heart, should take precedence in the legend of temperance. But it is always important to pay attention to shifts in tone in Spenser, and the abrupt shift from an outpouring of grief to confident ethical pronouncement must be a deliberately puzzling part of the fabric of this opening narrative.

\section{Hamlet: a heart unfortified}

In the opening of Hamlet the bifurcation between head and heart is in some ways simplified, as the head is associated with the new ruling regime and the broken heart with Hamlet. Hamlet opens with a greeting between Francisco and Barnardo, and Francisco's pronouncement, "'tis bitter cold / And I am sick at heart" (1.1.8-9). While we seem to be initially directed to the (possibly Augustinian) heart, the entrance of the very Roman-sounding Horatio and Marcellus strikes a different note, that of Shakespeare's Roman plays, and so creates an implicit expectation that Stoic rather than Christian concerns will be at issue. Horatio develops the expectations of the Roman with his descriptions of the portents surrounding the death of Caesar. But then Marcellus tells a folk story of the singing of the "bird of dawning" (1.1.160) and the arrival of "that season... / Wherein our Saviour's birth is celebrated" (1.1.158159), and the frame and expectations shift again. 
The mixed expectations created by references to both classical and Christian are used with slippery effect by Claudius in his speech denouncing Hamlet's grief. Claudius's description of Hamlet's faults runs parallel to Guyon's description of the overthrow of Mordant and Amavia. In the same way that "raging passion with fierce tyranny / Robs reason of her dew regalitie" in FQII, Claudius sees Hamlet's behaviour as concerned with failures of temperance, leading to failures in the governance of prudence, which results in fortitude becoming the ally of passion rather than reason, which leads to a breakdown in the internal justice of the whole self. Hamlet's grief is "unmanly" (1.2.94) - in other words, it lacks fortitude. His will is "most incorrect to heaven" (1.2.94); in other words, it lacks justice. As a result his heart is "unfortified" (1.2.96) like that of Amavia, at risk of overthrow by passion. He also lacks the governance of prudence, showing instead "a mind impatient, / An understanding simple and unschooled" (1.2.96-97). Hamlet is in short (in Claudius's view) behaving intemperately, and his intemperance is demonstrated through being out of tune with heaven, nature and reason. In other words, being out of tune with the rational order of the Stoic universe is reflected in the disruption of the proper functioning of the cardinal virtues.

But Claudius's reference to the "first corse"(1.2.105) shifts the confident portrayal of a rationally ordered universe to a picture of the human disorder that inevitably follows the Fall, the disorder seen in the first act of unnatural murder of brother by brother. Claudius's reference to the first murder is of course a Freudian slip, a clue to his own guilty conscience and so his own hypocrisy. But the natural order of the universe, and the inevitability of death, is less rational when death has come through the intemperate violence of the speaker, whatever Claudius's sleight of hand suggestion that this is otherwise.

When the King leaves the stage, Hamlet reaches immediately for the option of suicide. That Hamlet desires suicide at this early stage of the play again suggests a Stoic cast of mind, and the importance of Stoic principles to the play. That he rejects suicide for the reason of Christian sanctions against it, because the Everlasting has "fixed / His canon 'gainst self-slaughter" (1.2.131-2), suggests not so much an acceptance of governing Christian principles as an irritation with and underlying resistance to them. His will is not "most incorrect to heaven" (1.2.95), in so far as he does not now act on his impulses, but those impulses themselves show an injustice in the natural ordering of the self that is incompatible with Christian redemption and the 
hope and faith in the promise of eternity described by Augustine. His despairing condition is not far removed from that of Amavia, and the cause is also heart-sickness.

That his heart is "unfortified" is made clear in his desire to dissolve into nature without any act of will at all. Gail Kern Paster argued at the Toronto Spenser Studies Conference of 2006 that Amavia's bloody demise involves a humoral exchange with the natural elements as her "goreblood thick" (II.i.39.7) leaks out into and becomes one with the "grassy grownd" (II.i.39.9), dyeing it a "deepe sanguine" (II.i.39.9). Her heart-sickness becomes one with the surrounding world, and it is something like this kind of melting into the outer world that Hamlet desires. Hamlet sees his "flesh" as irretrievably "sullied" (1.2.129), (I am aware I am choosing a textual reading here against Edwards' choice of "solid") and this shows an Augustinian concern with innate concupiscence. Hamlet, in other words, sees himself as something like Amavia, trapped by a Mordant who represents the flesh. And what is then at issue is a lack of fortitude as a result of a lack of internal justice of the self. Hamlet is imagining that the worrying mortal flesh that causes all the problems in the world could just melt away, and with such melting the self, lacking all shape and substance, would just internally disintegrate. He lacks the structure and defences of the self provided by the cardinal virtues.

While the virtue of fortitude is often seen in terms of bearing and “forebearing", Hamlet demonstrates contrary failures. He yearns, first, to give up entirely in an ultimate act of cowardice, and then to attack the self and overcome its defences with something like the "bold furie" (II.i.57.8) of Amavia. What he implicitly wishes he did not have to resist, or could escape resisting, as is shortly made clear, are the wayward human passions that have so disrupted the natural inner justice of the self of his mother. And by the end of the soliloquy it is made explicit that he is suffering, like the anguished Amavia, from an overwhelming heartsickness: "But break, my heart, for I must hold my tongue" (1.2.159).

The need for the defences of the self to resist internal dissolution is reinforced in the play when Ophelia's watery death shows the consequences of the lack of such defences. Her suicide comes close to enacting Hamlet's desire for a watery melting away. The water comes to her, rather than the other way around, as the grave diggers describe it (5.1.15). And she has become so much "a creature native and indued" (4.7.179) to the element of water that she is "[a]s one incapable of her own distress" (4.7.178). Passively, without an act of reason or the will, she dissolves away into the muddy water. 
Hamlet still yearns, in the central soliloquy, for this kind of passive dissolution.

To die, to sleep -

No more; and by a sleep to say we end

The heart-ache and the thousand natural shocks

That flesh is heir to - 'tis a consummation

Devoutly to be wished. (3.1.60-64)

This seductive argument parallels that of Despayre to Redcrosse Knight in FQI, and the parallel shows how strongly Hamlet's own suicidal urge is that of despair.

Is not short payne well borne, that brings long ease,

And lays the soule to sleepe in quiet graue?

Sleepe after toyle, port after stormie seas,

Ease after warre, death after life does greatly please. (I.ix.40.6-9)

But while Redcrosse Knight is in despair because of his recognition of his own sinfulness, a despair heightened by a vision of the suffering of the damned in hell, Hamlet is deterred from the act of suicide by the possibility of eternal consequences.

While "[t]he undiscovered country from whose bourn / No traveller returns" sounds more classical than Christian, a place that might be reached by a journey over the River Styx, the "dread of something after death" (3.1.78) has stronger connotations of the possibility of eternal damnation. Hamlet in essence realises that "death after life" will not be identical to "sleep after toyle." He is not in the end taken in by the (for him) seductive argument of Spenser's Despayre. Gertrude has claimed that "all that lives must die, / Passing through nature to eternity" (1.2.72-3). If death is in no way particular, its consequences are a matter indifferent to the individual, and do not need to be too seriously considered. Gertrude's stoicism in the face of her husband's death in this sense lies behinds her son's view of suicide as a desirable option. Death in Gertrude's description is a Stoic-sounding return to nature of the sort envisaged by Hamlet's melting, thawing and resolving into a dew.

But this is not the only view of death in the play. The ghost brings a different view of the afterlife, a tale of a prison house "whose lightest word / Would harrow up thy soul" (1.5.15-16). The tension between these two world views underlies Hamlet's central soliloquy (despite its classical-sounding language and the contradiction between death as a country from which no traveller returns and the appearance of the ghost). In the end it is the possibility of eternal consequences that puzzles Hamlet's 
will, that prevents him from deciding to take fortitude to the level of homicide against the self with a "bare bodkin"(3.1.76).

Hamlet's worry about "what dreams may come" (3.1.66) is apparently interrupted by his concern with the civic injustices of the world, which any rational person might seek to avoid. But it becomes clear that it is another sense of justice that is really his underlying concern. Civic injustices lead him to the potential for other ills "that we know not of" (3.1.82). While it is the "pale cast of thought" (3.1.85) that leads to the disabling of the will to commit suicide, it is thoughts about justice which cause the disabling effect. It is the will that is puzzled and paralysed because of an underlying sense of right and wrong. And so at this moment Hamlet is closer to an Augustinian view of justice, as the right ordering of the self in relation to the divine, than to a Stoic view of suicide as an acceptable release from the vicissitudes of life. But it is important to note that Hamlet does not see the puzzling of the will which results from the "pale cast of thought" as a victory for prudence, but rather as a defeat for fortitude. The consequence of reflection is to disable action, to make him a coward. As in the first soliloquy, Hamlet cannot reject his knowledge of a Christian world order and Christian sanctions, but sees this life-affirming knowledge as an obstacle to action. If Denmark is a prison, for Hamlet so too is a Christian world-view to his desire for both suicide and revenge. The implicit message is that he would rather be a Stoic. But accepting an argument against suicide because of eternal consequences, however nebulously such consequences are expressed, becomes a morally doubled-edged sword. Hamlet, not having killed himself, can now pursue revenge. But he has unlocked the problem of divine sanctions against any act of violence - against the self or others. It is, more importantly, this problem of justice to which thinking has led him rather than the act of thinking itself that has become the obstacle to his action.

When we come to the only actual suicide in the play, the death of Ophelia, the terms of reference become initially strongly Christian. The gravedigger opens Act Five with the question of whether Ophelia deserves a "Christian burial" (5.1.1). The sanctions of the time against suicide were extremely strong. That Ophelia deserves to have "[s]hards, flints and pebbles" (5.1.198) thrown at her should not be seen as hyperbole or peevishness on the part of the priest or doctor of divinity, whether Catholic or Protestant. Jeffrey Watt describes the treatment accorded to suicides in Calvinist Geneva. One who stabbed himself in the woods after contracting a venereal disease had his body dragged on a hurdle through the streets 
by church authorities, and then impaled and exposed outside the city as a warning to others. Another, in dispute with a nephew and called to account for herself in front of the Consistory Council, drowned herself. Her body was then dragged through the streets, and she was buried shamefully at the site of executions (Watt 463). Hamlet's gravediggers hint that bribery has been involved in allowing Ophelia's Christian burial. The priest states directly that "great command" (5.1.195), presumably that of the King, has overruled the Church. That such measures were required speaks for the power of the underlying ecclesiastical sanctions.

It is curious to place this Christian burial of a suicide against the classicalsounding burial of Spenser's Mordant and Amavia by Guyon and the Palmer:

The great earthes wombe they open to the sky,

And with sad Cypresse seemly it embraue,

Then couering with a clod their closed eye,

They lay therein those corses tenderly,

And bid them sleepe in euerlasting peace. (II.i.60.2-6)

But to see one as Christian and one as classical is not secure. For just when we might feel we have established clearly Christian terms of reference in Hamlet, the language of Laertes' grief takes a classical turn - he wants now to die with Ophelia in a grave that sounds as if it belongs with the epic and heroic.

Now pile your dust upon the quick and dead

Till of this flat a mountain you have made

T'o'ertop old Pelion or the skyish head

Of blue Olympus. (5.1.218-21)

As with the burial of Mordant and Amavia, we are reminded of the physical nature of the grave dug out of the earth and open to the sky to be filled with a mound of earth. And although the gravediggers and the priest may condemn her, an element of doubt has been established in the play about the nature of Ophelia's death - it is "doubtful" (5.1.194) because it is not clear that it was not chosen "wittingly" (5.1.11). Her case, like Amavia's, has been reserved "to her eternal doom" (II.i.58.8). There are strong overtones of compassion in both acts of burial that must sit uncomfortably with the Christian sanctions of the time.

What is clearly the same in the deaths of Amavia and Ophelia is the ability for grief to destroy life - they are studies of the same aspect of intemperance. Ophelia's heart has clearly been "unfortified" (1.2.96). She represents the "unmanly 
grief" (1.2.94) that Claudius condemns at the beginning of the play. Like the womanly Amavia, she has died because the control of reason has been completely undermined by her grief. All the play's preaching about excessive grief in mourning finds expression in her death; like the emblematic Amavia, she demonstrates the unravelling of all the cardinal virtues and the dissolution of the internal justice, the right order, of the self. What remains problematic in Ophelia's as in Amavia's case is the proper judgement of this sort of suicidal intemperance, caused as it has been by an act of injustice.

The dilemma represented by Ophelia - how to respond rationally to the rejection of a lover and the death of a father at that lover's hand - is portrayed as an intolerable one, one that in the play defeats rational control entirely. Hamlet's dilemma - how to respond rationally to the death of his father at the hand of an uncle and the marriage of that uncle to his mother and without sacrificing his own life - is portrayed as similarly intolerable. If we view Hamlet in Stoic terms, Ophelia demonstrates the argument that there are conditions of excessive misery that can make the act of suicide acceptable. In Augustinian terms, Ophelia demonstrates the intrinsic misery of life and the need to seek for solutions to this misery outside its temporal conditions. 


\section{Chapter Six: Means, Decorum and Mediocrity}

In the fifty-eighth stanza of Canto 1 of The Legend of Sir Guyon, or of Temperaunce Guyon moralises over the dilemma of Mordant and Amavia in terms of "a meane" (I.i.58.2). Very early in this book of The Faerie Queene it appears Spenser is helping the reader by providing something like a definition of temperance.

But temperaunce (said he) with golden squire

Betwixt them both can measure out a meane,

Nether to melt in pleasures whott desyre,

Nor frye in hartlesse griefe and dolefull tene.

Thrise happy man, who fares them both atweene. (II.i.58.1-5)

Temperance is the virtue that finds a middle path between lust and grief, this pronouncement suggests. But in typical Spenserian fashion, the "definition" of temperance combines many elements that enrich and complicate it.

\section{The medieval measuring square}

The use of the word "meane" points to Aristotle and his definitions of temperance in the Nicomachean Ethics; we will return shortly to this primary meaning. The allusion in "golden squire" to the carpenter's square, an implement common in Renaissance iconography of temperance, used to fix cornerstones, has connotations of holding true. It is therefore recalled by Spenser at the opening of Canto xii:

Now ginnes this goodly frame of Temperaunce

Fayrely to rise, and her adorned hed

To pricke of highest prayse forth to aduaunce,

Formerly grounded, and fast setteled

On firme foundation of true bountyhed. (II.xii.1.1-5)

This "true bountyhed" may be temperance firmly grounded in prudence. It may also be Christ as the cornerstone of faith or the rock of the Church or both, an insight I owe to Kathryn Walls' work on the carpenter's square in medieval allegory (Walls 261). In this case, the firm grounding of the temperate and very medievalsounding fortified castle of the self that is the House of Alma begins with the golden set-square of this early stanza. In this chapter the focus will shift to temperance in social and political contexts, but such medieval and Christian connotations mean the 
debate from the previous chapter over the relative importance of the philosophical and theological cannot be entirely laid aside.

\section{The Horatian "golden" mean}

A further aspect of the opening "definition" stanza of $F Q I I$ is the reference to the "golden squire." The goldenness of the squire evokes the Horatian "aurea mediocritas," the golden mean from Ode 2.10. And this in turn evokes the Romanisation of the Greek sophrosyne. As Horace is strongly influenced by Hellenistic philosophy, both originally Greek popular and philosophical meanings of sophrosyne, and their particular uses in Greek lyric poetry, permeate his verse (North 293). By the Renaissance, "the golden mean" is a commonplace term in its own right, and Spenser need not refer particularly to the original ode when he talks of a "golden squire." But Spenser is very likely to have studied the odes in school (Baldwin 498) and this ode was translated by his patron, Sidney.

Horace's ode both contains what will become commonplaces of temperance as a mean between extremes, and addresses a particular political context - probably that of Horace's friend Licinius who, according to Kenneth Quinn's commentary, appears to have got into political difficulties (Quinn 216). Here is the ode in Philip Sidney's translation, (published in 1598, but written before 1586, the date of Sidney's death).

\section{Ode II.10}

You better sure shall live, not evermore

Trying high seas, nor whole Sea rage you flee, Pressing too much upon ill harbourd shore.

The golden meane who loves, lives safely free

From filth of foreworne house, and quiet lives, Releast from Court, where envie needes must be.

The wynde most oft the hugest Pine-tree greeves:

The stately towers come downe with greater fall: The highest hills the bolt of thunder cleeves:

Evill happes do fill with hope, good happes appall

With feare of change, the courage well preparde:

Fowle Winters as they come, away they shall. 
Though present times and past with evils be snarde,

They shall not last: with Citherne silent muse

Apollo wakes, and bow hath sometime sparde.

In hard estate with stowt shew valor use,

The same man still in whom wysdome prevailes,

In too full winde draw in thy swelling sailes. (Carne-Ross \& Haynes, 73)

All of these Horatian metaphors are suitable for inclusion in a compendium of precepts of temperance. The allusion to the fall of high towers, and the risk to tall trees and mountains may amount to a compliment to the stature of the Licinius who has fallen under political attack (Quinn 215-16). The rest of the ode contains prudential advice - portraying temperance as a moderation that prevents harm in the contingencies of daily and political life. This popular prudential view of the mean and moderation, present from the origins of the concept of temperance, prefigures the teleology of Hume.

The ode is also an expression of a deeply desirable and habitually temperate cast of mind. The painstaking perfection of the poem, its curiosa felicitas (as Petronius styled Horace's poetry) reflects the deeper metaphysical harmony of sophrosyne. The person who is safe in loving the golden mean is safe in both an urgently required immediately political sense, and a more personal sense of tranquil inner happiness. Spenser, like Horace, also invites us to see the deeply philosophical, the immediately political and the socially useful in his treatment of the mean, and this chapter will pursue all three aspects in FQII and Hamlet.

\section{The Platonic mean}

We have already seen that the maxim "nothing in excess" is central to Greek thought. While Aristotle systematically applies this precept to ethical philosophy, some of this work is prefigured in Plato. Plato gives philosophical weight to the mean in the Statesman as a way of measuring excess and defect (North 185). In the Philebus, each part of the good life can be judged by the standard of the mean, and limit is involved in the classification of pleasures (North 185). Beauty is identified with symmetry and a mixture of knowledge and pleasure is essential for happiness in this dialogue. The sophron man gives obedience to meden agan, the traditional association we have examined in the introduction and more closely in Chapter Three (North 186). 
Spenser's "temperaunce with golden squire" measures out a mean between "pleasures whott desyre" and "hartlesse griefe and dolefull tene." There is a Platonic basis for this formulation in The Laws, where virtue is defined as a harmony of reason and emotion in terms of pleasure and pain. "Pleasure and pain, you see, flow like two springs released by nature. If a man draws the right amount from the right one at the right time, he lives a happy life; but if he draws unintelligently at the wrong time, his life will be rather different" (62; $636 \mathrm{D}-\mathrm{E})$. Virtue is also the concord (symphonia) of reason and habit in relation to pleasure and pain.

I call 'education' the initial acquisition of virtue by the child, when the feelings of pleasure and affection, pain and hatred, that well up in his soul are channelled in the right courses before he can understand the reason why. Then when he does understand, his reason and his emotions agree in telling him that he has been properly trained by inculcation of appropriate habits. Virtue is this general concord of reason and emotion. But there is one element you could isolate in any account you give, and this is the correct formulation of our feelings of pleasure and pain, which make us hate what we ought to hate from the first to last, and love what we ought to love. (Plato Laws 653; 86)

The ultimate Platonic instrument for the measure of virtue in the Laws is God, and Spenser's golden squire may carry this additional metaphysical implication, but only if it is seen in Platonic and not Aristotelian terms. As the passage in the Laws that links sophrosyne to the divine was in turn influential for the Church Fathers, the idea of Christ as the cornerstone of faith has this Platonic root.

What conduct is dear to God and follows after Him?...God would be for us the measure of all things... and he who would be dear to Him must become like Him, so far as possible. According to the present reasoning, the sophron among us is dear to God, for he is like Him, and the man who is not sophron is not like Him, but different and unjust. (Plato Laws 716C-D; quoted in North 194)

\section{The Aristotelian mean}

In one of the great historical divides in ethical thought, the Platonic metaphysical dimension of sophrosyne is overturned by Aristotle. God is not sophron for Aristotle; rather the activity of God was pure contemplation. While Aristotle was concerned with the process of assimilation to God, the path to such assimilation was not moral behaviour but reason. The mean and the self-knowledge of "gnothi sauton" were important for Aristotle in terms of ethics, but Aristotle renounces the injunction to "think mortal thoughts." Man should instead try to make himself immortal, and to exercise the reason that is the divine element in man, that alone enables man to share in the life of God. Moral behaviour however is not, in Aristotle's system, to be 
measured against God, but becomes relative to the individual as practical morality is separated out from contemplation. One of the clearest implications of this is that for Aristotle temperance, sophrosyne, becomes no longer a path to assimilation to God (North, 210-11).

Aristotle's definition of the mean derives in part from medical parallels, and he looks in the manner of a biologist for distinctions between virtues rather than attempting, like Plato, to look for points of unity between virtues. Sophrosyne, in the larger sense of meden agan, still lies behind Aristotle's doctrine of the mean, and it is in this sense that temperance and virtue can be equated (North 200).

All moral virtue in the Ethics is related to pleasure and pain, and as Aristotle establishes this point he distinguishes temperance and courage. The end to which courage aims may be a source of pleasure but courage is primarily to do with enduring pain. "And the more completely a man possesses virtue, and the more truly happy he is, the more painful death will seem to him" (Aristotle 102; III.ix.4). The intemperate man "is called intemperate because he feels an undue amount of pain at missing pleasures - here you have pleasure actually causing pain - and temperate because he is not pained by the absence of pleasure" (106; III.ix.5). Aristotle divides the soul into three faculties, the vegetative, the appetitive and the rational. Moral virtue belongs to the appetitive faculty (which is in one respect irrational and in another rational), and is acquired through habituation. Intellectual virtue belongs to the rational soul and is instilled through teaching. Temperance and fortitude are moral virtues for Aristotle; prudence an intellectual virtue (North 199).

Moral virtue is a habit of choice in Aristotle's thinking, and this view of morality permeates the scholasticism of the Middle Ages. The agent's state of mind determines the moral quality of his act. Pleasure and pain become an index to the possession of virtue. For Aristotle the pleasure and pain surrounding a given action will reveal the moral character of the agent. "A man is sophron, for example, not because he abstains from excessive bodily pleasure, but because he enjoys abstaining" (North 202). The one who does not enjoy such abstinence, but has to overcome base desires in order to obey the dictates of reason, is continent. "Sophrosyne is the effortless, because habitual, harmony of appetite and reason, the perfection of the healthy soul that needs no physician" (North 202-3).

As Aristotle broadens the number of virtues away from the four Platonic cardinal virtues, he correspondingly limits the nature of each particular virtue. Sophrosyne is limited to the pleasures of the body, those shared with the lower 
animals, eating, drinking and sexual intercourse. The two opposed vices are akolosia (which might loosely be defined as wantonness) and anaisthesia (insufficient enjoyment of pleasure). Unlike Stoic apatheia, sophrosyne in Aristotle does not mean abstinence. "The sophron person enjoys pleasures in moderation; he merely avoids the wrong pleasures and any pleasure in excess." Sophrosyne "renders the appetitive element obedient to reason" and Aristotle describes the sophron man as having an appetite for "what he may desire, in the right way, and at the right time" (North 200-202).

Another main distinction between Aristotelian and Platonic ethical philosophy lies in Aristotle's attack on the Socratic identification of virtue with knowledge and so the paradox that no-one can do wrong knowingly. Aristotle shows this in his distinctions between sophrosyne and enkrateia (continence). The person who has lost all principle is akolastes, the opposite of sophron. Akrasia is the condition in which the appetite for excessive bodily pleasure overcomes the dictates of reason. The akrates person is incontinent and morally weak, "mastered by passion to the point of abandoning principle, but not to the point of forgetting it" (North 203).

Spenser establishes the quest of his knight of temperance as vengeance on Acrasia, and in this sense makes the focus of the book the more narrow battles against the desire for pleasure. On the other hand Spenser's description of temperance as a mean between "whott desyre" and "hartlesse griefe, and dolefull tene," refers us to the wider use of sophrosyne of both Plato and Aristotle, a mean distinguished in terms of pleasure and pain that can be applied to all virtue.

\section{The Reformation and Aristotle}

The end of Guyon's presentation of a "temperaunce" that can measure out a mean between desire and grief with a golden squire is a promise of happiness, "thrise happy man, who fares them both atweene." Aristotle's formula for happiness, as seen by the Renaissance, was "life-long activity in accordance with virtue supplemented by sufficient bodily and external goods" (Kraye 330). While Aristotle's Ethics, an important cornerstone of scholastic teaching, continued to dominate ethics throughout the Renaissance, there were some strong theological points of conflict. Luther denounced the Ethics in 1517 as incompatible with the Christian doctrine of grace ("Tota fere Aristotelis Ethica pessima est gratiae inimica" (qtd Kraye 343)). Luther's denunciation associates Aristotelian virtue acquired through teaching, practice and the development of moral habits with the (from the 
Protestant perspective) Catholic doctrine of works, and the attack on Aristotle is part of a more general attack on scholasticism. The problem arises in thinking that one can merit God's grace through one's own actions (Kraye 343-4). It is interesting to note that Gabriel Harvey, in trouble at Cambridge for disagreement with Aristotle, made one of his points of disagreement "virtus non est in nostra potestate" (virtue is not within our power) (Stern 22).

The objection to Aristotle does not rest on the Protestant side alone. For the Catholic Vives, Aristotle was less compatible with Christian thought than Plato and the Stoics, "first, because Aristotle limited happiness to the present life; and second, because the earthly felicity which he described not only differed from but actually conflicted with the beatitudes of this life recounted by Christ in the Sermon on the Mount" (Kraye 344). There was also strong disagreement among Christian writers with Aristotle's contention that sufficient bodily and external goods were needed for happiness. Those who defended Aristotle used Melanchthon's separation of the domains of faith and ethical behaviour, and the argument that following the law of reason was in accordance with the law of God (344). Between the two extremes - of rejection of the Ethics out of hand, and a view of their complete compatibility with Christian doctrine - a range of points of compromise were reached, including seeing Aristotelian precepts as a path to the higher morality of the gospels. Spenser's early introduction of references to the mean into $F Q I I$, and his development of the mean in the episode of the Castle of Medina, must be approached with some caution in the light of this background.

\section{Aristotelian means and extremes and Spenser's Castle of Medina}

From this point, and through the next chapter, we will follow Guyon's progress into the narrative of $F Q I I$ and up to the point of his collapse and rescue by an angel. As we do so, we seem initially to be dealing with a temperance concerned with moral behaviour in social and political contexts and the psychology of temperance as selfcontrol, and to have mostly left theology behind. Spenser moves from the tableau of Mordant, Amavia and the Bloodie Babe, a passage we have seen in terms of original sin, to the sequence in the next canto of the Castle of Medina. ${ }^{3}$ The Babe will be left at this Castle and Medina is asked "in vertuous lore to traine his tender youth," a

3 A version of the argument that follows was presented as an unpublished paper. Gillian Hubbard, “"Two so mighty warriors': Calvin's Stoicks and Epicures in Spenser's House of Medina," Session sponsored by the International Spenser Society, Sixteenth Century Studies Conference, Crowne Plaza Hotel, Geneva, 29 May 2009. 
phrasing which suggests the Aristotelian development of virtuous moral habits. In the argument for Canto II, Medina is described as "the face of golden Meane" with her sisters "two Extremities," who "striue her to banish cleane." Aristotle's discussion of the nature of the mean and extremes in Chapter Eight of Book Two of the Ethics is helpful for this conflict.

Thus there are three dispositions, two of them taking a vicious form (one in the direction of excess, the other of defect) and one a good form, namely, the observance of the mean. They are all opposed to one another, though not all in the same way. The extreme stages are opposed both to the mean and one another, and the mean is opposed to both extremes. For just as the equal is greater compared with the less, and less compared with the greater, so the mean states (whether in feelings or actions) are in excess if compared with the deficient, and deficient if compared with the excessive, states. Thus a brave man appears rash when set beside a coward, and cowardly when set beside a rash man; a temperate man appears intemperate beside a man of full sensibilities, and dull if contrasted with an intemperate man. This is the reason why each extreme character tries to push the mean nearer the other. The coward calls the brave man rash, the rash man calls him a coward. (72; II.viii.16)

In the Castle of Medina, "[t]he eldest did against the youngest goe, / And both against the middest meant to worken woe" (II.ii.13.8-9). The swains of these sisters, Huddibras and Sansloy, first attack each other and then, when Guyon intervenes, Guyon. Our protagonist initially seems to evade this attack, and like a breaking wave, "[d]oes ride on both their backs, and faire her self doth saue" (II.ii.24.9). But as the battle proceeds, it becomes unclear who is being pushed where: it is uncertain who is "[n]ow forst to yield, now forcing to inuade" (II.ii.25.7). The role of Medina, rushing between them all, is conciliatory, looking for them to "misseeming discord meekely lay aside" (II.ii.31.9). While the two swains are more generally opposed in the lawlessness of Sansloy and Huddibras' opposition to all things (who in a wonderful Spenserian wordplay " $[\mathrm{h}]$ ardly could endure his hardiment" (II.ii.37.8)), the two sisters are more clearly the extremes opposed to temperance, the anaisthesia of insufficient enjoyment of pleasure of Elissa, who "euermore did seeme / As discontent for want of merth or meat" (II.ii.35.3-4), and the akolosia or abandon of Perissa, who had "[n]o measure in her mood, no rule of right, / But poured out in pleasure and delight" (II.ii.36.4-5). Medina's process is to restore a balance to each pair to bring them closer to the mean.

That forward paire she euer would asswage,

When they would striue dew reason to exceed;

But that same froward twaine would accorage,

And of her plenty adde vnto their need (II.ii.38.5-8) 
One side needs to be dampened down, the other to be strengthened with courage or fortitude.

\section{The mean and religious dispute}

Finding concord in a tension between the "forward" and the "froward" has strong political connotations, and in Spenser's period is unavoidably associated with the via media of the Elizabethan Church Settlement. One way of seeing the Elizabethan via media is as a middle path between Catholicism and extreme Protestantism, and this is particularly true for its roots in the reigns preceding the accession of Elizabeth I to the throne. Critics have over the years attempted more precise political allegorical correspondences. Daniel Doerksen in The Spenser Encyclopaedia sees the allegory of the House of Medina in terms of the descendants of Henry the Eighth, with Elissa as the discontented and austere Mary Tudor, Medina as Elizabeth, and Perissa as the (in Elizabethan eyes) debauched Mary Queen of Scots. Huddibras is seen by Doerksen as Phillip of Spain, Sansloy as either Mary Queen of Scots' lover Bothwell, or John of Leiden, the leader of the Anabaptist revolt in Munster in 1533 (Doerksen 464). Hamilton's edition of The Faerie Queene suggests two opposed possibilities: that "Elissa...represents the Church of Rome or, in her austerity, the Puritans; and the younger Perissa represents the 'lawless' Anabaptists or, in her sensuousness, the Church of Rome" (Spenser 174).

If it is possible to see Perissa as either Anabaptist or Papist, there are obviously difficulties with assigning precise one-to-one political correspondences to Spenser's allegory, and the problem is increased if we narrow the field from the extremes of Catholic and Anabaptist to the divisions within the Established Church in the years subsequent to the settlement and before the publication of the first three books of The Faerie Queene in 1590. Joshua Scodel's study, Excess and the Mean in Early Modern English Literature makes it clear how relative a term the mean could be in a political context, with many Protestant opponents of the church settlement proclaiming that they represented the middle way between "popery" and Protestant extremism, and so attacking "opponents as hypocritical representatives of a vicious extreme" (Scodel 5). In the middle, moderates could be seen as fundamentally lacking in conviction, because they were unwilling to argue strongly for their position, and to be condemned in the Biblical terms of Rev.3.15-16 for being lukewarm. For a zealous proponent of one or other opposed position against the via media, the "louely concord, and most sacred peace" (II.ii.31.1) made by Spenser's 
Medina - if this allegorical figure is to be identified with the fledgling established church - would be highly suspect, and this principle applies for any other context of disagreement where the mean is not also established as a term with some absolute force. Aristotle establishes temperance as an absolute virtue as well as a mean, but placing it absolutely in any given situation remains a relative business.

\section{Stoic and Epicurean extremes}

As Guyon moves away from the Castle of Medina, the contrasting episodes of the Cave of Mammon and Bower of Bliss of $F Q I I$ can be seen to follow the pattern established by the opposed pairs of Huddibras / Elissa and Sansloy / Perissa. The Bower is clearly about lawless excess; the journey through the Cave is presented as one where absolute resistance to its temptations is paramount. Here another opposed pattern of discourse associated with the church may be at work, a conflict between Stoicism and Epicureanism, the Porch and the Garden. Reid Barbour in English Epicures and Stoics: Ancient Legacies in Early Stuart Culture argues that "early Stuart culture is diacritically obsessed with the Stoics and Epicureans, apart from and in relation to one another;...the Stoics and Epicureans afford early Stuart readers and writers with the most impressive yet vexatious answers to many of their most urgent political and religious questions" (Barbour 2-3). While most of Barbour's argument, like that of Scodel, is presented through references outside our period, the pattern he is suggesting also fits Spenser's opposition of a journey dependent on a denial of worldly goods for the sake of virtue through the Cave of Mammon, on the one hand, and on the other, of a journey to an island of decadent self-indulgence that is harder to resist. In one stereotype in the Stuart period of the two contrasting philosophies, Stoic extirpation of the passions is associated with the Protestant campaign against self-indulgence, and Epicureanism with hedonism, atheism and any echoes of papist idolatry. Barbour includes the following from Henry Holland in the Elizabethan period, giving this view of the two opposed camps in his commentary on Acts 17. The Epicures "deny providence in order to ignore the eventuality of judgement," and the Stoics claim that God is so chained by providence that there is no space for God to exercise his own will (Barbour 233).

Acts 17 is also directly relevant to the House of Medina episode. When we examine Calvin's commentary on the passage in Acts 17, in which Paul is confronted in Athens by the Stoics and Epicureans, we find wording close to Spenser's portrayal of the battle with Huddibras and Sansloy. Calvin (in a sixteenth-century English 
translation of his commentary) allows only those who gave their name to the God of Israel to be religious; all other religions are condemned with "the reproach of atheism, howsoever they toil and moil in superstition".

Neither is it to be doubted but that the Epicures, according to their wonted frowardness, did trouble the holy man; and that the Stoics, trusting to their subtile quips and cavils, did stubbornly deride him; yet the end shall show that he did not dispute sophistically, neither was he carried away unto any unprofitable and contentious disputation, but did observe that modesty which he himself commandeth elsewhere. (Commentary 18)

Calvin adds advice that would serve Guyon well, and could issue from Medina. "And thus must we do, that by refuting meekly and modestly vain cavillings, we may utter that which is sound and true; and we must always avoid this danger, that ambition or desire to show our wit do not wrap us in superfluous and vain contentions" (18).

Calvin's definitions of the two schools, diametrically opposed in his opinion, both show knowledge of the original philosophies and reinforce the more stereotypical view of them in the period. According to Calvin, the philosophy of the Epicures "was to feign that the sun was two feet broad, that the world was made ex atomis (or of things so small that they could not be divided or made smaller), and by deluding men thus, to blot out the wonderful workmanship which appeareth in the creation of the world" (18). Although the Epicureans accepted that there were gods, they imagined them as idle in heaven, and believed there was no divine providence or governance of men's affairs. Spenser's Sansloy is naturally aligned with such a philosophy, and so is the Perissa who lives for pleasure, along with Phaedria and the Acrasia of the Bower of Bliss with their carpe diem songs about the rose that lives for only a day:

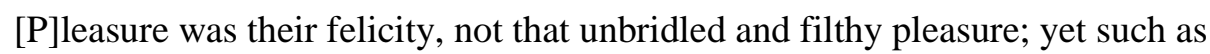
did more and more corrupt men by her enticements, being already, of their own accord, bent to pamper the flesh. They counted the immortality of their souls but a fable, whereby it came to pass that they gave themselves liberty to make much of their bodies. (18)

The Stoics are, according to Calvin, guilty of an opposed problem with providence:

though they said that the world was subject to the providence of God, yet did they afterwards, through a most filthy surmise, or rather doting, corrupt that point of their doctrine. For they did not grant that God did govern the world by counsel, justice, and power, but they forged a labyrinth of the compass or agreement of the causes, that God himself being bound with the necessity of fate or destiny, might be carried violently with the frame of heaven, as the poets do tie and fetter their Jupiter with golden fetters, because the Fates or 
Destinies do govern when he is about something else. Though they placed felicity in virtue, they knew not what true virtue was, and they did puff up men with pride, so that they did deck themselves with that which they took from God. For though they did all abase the grace of the Holy Ghost, yet was there no sect more proud. They had no other fortitude, but a certain rash and immoderate fierceness. (18)

Pleasure is, in this Calvinist formulation, the felicity of the Epicureans; "a certain rash and immoderate fierceness" of fortitude, the mark of the Stoics. This chimes with the Elissa / Sansloy and Perissa / Huddibras dichotomy in Spenser. The first pair demonstrates both love of pleasure and a general lawlessness, the second a love of abstention and resistance for its own sake (and this dichotomy is played out in a range of ways in the wider legend of temperance). Paul, in Calvin's commentary on this episode in Acts, stands as a mean between the two philosophical schools as opposed forces.

Therefore there was in Paul wonderful force of the Spirit, who standing amidst such beasts, which sought to pull him to and fro, stood firm in the sound sincerity to the gospel, and did valiantly withstand and endure, as well the dogged malapertness of the former sect, as the pride and crafty cavillings of the other.

The "wondrous great prowesse and heroick worth" (II.ii.25.3) that Guyon "shewed that day, and rare ensample made, / When two so mighty warriours he dismade" (II.ii.25 4-5), in all probability echoes this Scriptural battle. To see the Medina episode in terms of Calvin's commentary on Acts is to point to Paul and the Pauline defence of gospel truth as the source of the real mean of temperance in FQII, an argument I am not aware has been made explicitly before.

In the realpolitik of the Elizabethan Settlement, there are two flash-points in the struggle of the "forward" camp of reforming clergy after what was hoped by this camp to be a transitional rather than a final settlement of ecclesiastical policy in England. One was over vestments, and in relation to this Medina's garments evoke an ecclesiastical compromise between opposed positions. Medina is "a sober sad, and comely courteous Dame" (II.ii.14.5) who is "rich arayd, and yet in modest guize" (II.ii.14.6), suggesting the Elizabethan middle way to canonical dress. There was much defiance among many Protestant ministers, particularly those who had returned from the Protestant communities of Europe after the accession of Elizabeth, of the injunction to wear ecclesiastical garments of any sort, and this injunction became one of the tests of the strength of the Elizabethan Settlement itself. Medina's hair is a model of order. "Her golden lockes she roundly did vptye / In breaded 
tramels, that no looser heares / Did out of order stray about her daintie eares" (II.ii.15.7-9). The strength of the forces opposed to an ecclesiastical middle way are made apparent by Medina's subsequent disarray in attempting to calm the discord between Huddibras, Sansloy and Guyon: "The faire Medina with her tresses torne, / And naked brest, in pitty of their harmes, / Emongst them ran" (II.27.2-4), and something closer to the actual discord within the English church of Spenser's period is suggested.

There is a theological problem from the first with "breaded trammels," as Peter 3.3 proclaims: "Let not yours be the outward adorning with braiding of hair, decoration of gold, and wearing of robes", and so Spenser's use of braiding hints that Medina is to be associated both with a compromise that favours the old Catholic forms, and with pride. In the section of the Summa Theologiae which considers the virtues associated with temperance, Aquinas uses the Augustinian argument of following local custom to soften Peter's injunction, and makes a special distinction for priests to be allowed to wear clothes that distinguish them, "not for their own glory, but to signify the nobility of their office and of divine worship," and it is from similar arguments about appropriate clothes for the clergy that the position of the church about vestments under Elizabeth proceeds. Medina's "lovely concord" would thus be suspect from the perspective of those belonging to the "forward" reforming clergy.

From the perspective of the Queen, who sought to maintain the stability of her throne against external threat, and to establish through church spokespeople like Hooker, and later Whitgift, a church that was (to the reformers) more Erastian than Calvinist in its leanings, the "forwardness" of the reforming parties was irksome and met with increasing resistance. When Archbishop Grindal (the "Algrind" of Spenser's Shepheardes Calendar) refused to rein in the practice of prophesying in his parishes (the discussion and exegesis of Scriptural passages to which laypeople could also contribute), he was punished with sequestration, and had scarcely regained the Queen's favour at the time of this death. Grindal's letter of defence to the Queen marks him as "froward" in his act of stubborn resistance to the Queen's will, "forward" in his defence of continental Protestant practice, and straight-out foolhardy in terms of his own political safety. Using Ambrose's arguments for the right of a bishop as an ecclesiastical representative of God to challenge the monarch, he casts himself in the role of the sophronistes described in Chapter Four. He also argues, citing the prophet Ezekiel, that ministers of the church should be watchmen 
[speculatores], not flatterers [adulatores]. "If we see the sword coming by reason of any offence towards God, we must of necessity give warning, or else the blood of those who perish will be required at our hands" (Nicholson 377).

It becomes difficult to see the House of Medina episode as a defence of the via media if this is to make Grindal a forward Sansloy figure or a froward Huddibras figure, given Spenser's known sympathy for Grindal's position and his allegorical treatment in The Shepheardes Calendar as a shepherd of his ecclesiastical flock, a good shepherd who comes under violent attack. In this case, we must see the "louely concord and most sacred peace" achieved by Medina as more of an ideal to be aimed for than the reality of current practice at the time of the writing of $F Q \mathrm{II}$. And this would chime more closely with the reading I have just given of Paul in Acts 17, torn between the Stoics and the Epicureans. In this case, a "louely concord" would best be achieved by the Pauline interpretation of the Word, of the kind of privileging of the Scripture favoured by the reforming camp and enacted in the practice of prophesying. Reading the House of Medina less in terms of the virtuous Aristotelian mean, and more in terms of challenges (both philosophical and theological) to the centrality of the interpretation of the Gospel, would also explain why Guyon and the Palmer would entrust the Bloody Babe to Medina's "truth" with the injunction to train his youth in virtuous lore.

\section{Cicero and temperance as social decorum}

The Castle of Medina episode can, we have seen, be read philosophically, politically and theologically. It can also be read in terms of social behaviour and the rules for decorum of Cicero and (in many ways following him) Aquinas. What Medina seeks among the warring parties is among other things a propriety or decorum of behaviour. "Betwixt them both the faire Medina sate / With sober grace, and goodly carriage: / With equal measure she did moderate / The strong extremities of their outrage" (II.ii.38.1-4), and in this way, "[s]o kept she them in order, and her selfe in heed" (II.ii.38.9). In Cicero's formulation of the cardinal virtues in De Officiis, temperance is broadened to a virtue "in which we find considerateness and selfcontrol, which give, as it were, a sort of polish to life; it embraces also temperance, complete subjection of all the passions, and moderation in all things. Under this head is further included what, in Latin, may be called decorum (propriety); for in Greek it is called prepon. Such is its essential nature, that it is inseparable from moral goodness; for what is proper is morally right, and what is morally right is proper" 
(Cicero 97; I.xxvii.94). Although Cicero argues that "the nature of the difference between morality and propriety can more easily be felt than expressed," true propriety can only be found when there is a pre-existing moral rectitude. In this case all the cardinal virtues evince propriety. "For to employ reason and speech rationally, to do with careful consideration whatever one does, and in everything to discern truth and to uphold it - that is proper. To be mistaken, on the other hand, to miss the truth, to fall into error, to be led astray - that is as improper as to be deranged and lose one's mind" (97; I.xxvii.94). Fortitude is similarly an aspect of propriety; its contrary, cowardice, is clearly seen in Spenser's third canto, in the actions of Trompart and Braggadochio. "What is done in a manly and courageous spirit seems becoming to a man and proper; what is done in a contrary fashion is at once immoral and improper" (97; I.xxvii.94).

As we saw in the preceding chapter, for the Stoics virtue is involved in agreement with the laws of nature. Cicero here applies this principle particularly to temperance, defined in terms of the control of the appetite by reason:

[T]he essential activity of the spirit is twofold: one force is appetite (that is, orme in Greek), which impels a man this way and that; the other is reason, which teaches and explains what should be done and what should be left undone. The result is that reason commands, appetite obeys. (103; I.xxviii.101).

The spirit of the "sober grace, and goodly carriage" (II, ii.38.2) of Medina is seen in Cicero's corollary statement: “[E]very action ought to be free from undue haste or carelessness; neither ought we to do anything for which we cannot assign a reasonable motive" (103; I.xxix). The appetites must neither run ahead nor lag behind the control of the reins of reason, and for Cicero Stoic apatheia is the goal: people "should enjoy calm of soul and be free from every sort of passion" (105). This underlying philosophy leads to a set of rules for behaviour. Humour, to begin with, should not be "extravagant or immoderate, but refined and witty." Sensual gratification should be kept "strictly within the limits of moderate indulgence" (109; I.xxx.106). In more general terms, it is wrong "to abandon ourselves to excess and to live in luxury and voluptuousness"; on the contrary it is right "to live in thrift, self-denial, simplicity and sobriety" (109; I.xxx.106). A harmony is also needed between the more universal laws of propriety, and a holding fast to each person's peculiar gifts, a not going against the grain of one's own nature. The young and old, magistrate, private citizen and resident foreigners all need to behave appropriately to their station in life (125; I.xxxiv.122), and this deeply 
socially conservative strand of thought that begins in Plato's Republic and Laws is strongly echoed in Calvin. Propriety should also be shown in bodily actions, in modesty. The rule here is to avoid extremes: "[O]ur conduct and speech should not be effeminate and overnice, on the one hand, nor coarse and boorish on the other" (131; I.xxxv.109). The same is true of dress (and effeminacy in male dress and gesture is particularly singled out to be avoided). Medina's neatness represents a Ciceronean ideal: "We must besides present an appearance of neatness - not too punctilious or exquisite, but just enough to avoid boorish and ill-bred slovenliness" (133; I.xxxvi.130) and decorum in movement is also required. Decorum is also needed in oratory, in conversation, and in the offering of reproofs (135-9; I.xxxvii.132-135). As we have seen in the Horatian ode, moderation should also be seen in one's home, and for Cicero, one's occupation should also be fitting to one's station in life.

In the Summa Theologiae, Aquinas echoes some of these Ciceronean categories in the virtues associated with temperance, as he sets the rules later to be associated with temperance in the medieval period and well into the Renaissance and Reformation. Aquinas cites Cicero in placing modesty as a part of temperance rather than to be equated with it (2.2ae.160.1). For Aquinas, modesty is the virtue required "where moderation is not so difficult" as in matters of sex and food. He gives as a sub-category of modesty humility which tempers the desire for self-excellence, and studiousness which is the opposite of curiosity and which tempers the desire to be a know-all (160.2). Finally there is decorum in bodily actions and dress. Here Aquinas offers a compromise, citing Paul in 1Timothy 2. 9 commending women who adorn themselves modestly and sensibly in seemly apparel, not with braided hair or gold or pearls or costly attire (169.2). For Aquinas, what is forbidden is extravagant, shameless and immodest, not sober and well-styled adornment. Cosmetics are also condemned. The young Perissa of the House of Medina shows the excess in attire condemned both by Cicero and Aquinas: "In sumptuous tire she ioyd her selfe to pranck" (II.ii.36) and is in accompanying fashion "of her loue too lauish (litle haue she thanck)" (II.ii.36.9). The ultimate failure of both modesty and moderation of dress is found in the Bower of Bliss, when Acrasia is discovered upon a bed of roses, where she "was arayd, or rather disarayd, / All in a vele of silke and siluer thin, / That hid no whit her alablaster skin, / But rather shewed more white, if more might bee" (II.xii.77.3-7). 
Spenser's Elissa and Perissa are drawn in terms of extremes in clothes, in entertainment and lovemaking and eating. Elissa:

$$
\text { did deeme }
$$

Such entertainment base, ne ought would eat,

Ne ought would speake, but euermore did seeme

As discontent for want of merth or meat;

No solace could her Paramour intreat

Her once to show, ne court, nor dalliaunce,

But with bent lowring browes, as she would threat,

She scould, and frowned with froward countenaunce,

Vnworthy of faire Ladies comely gouernaunce. (II.ii.35)

While Perissa "was of another mynd":

Full of disport, still laughing, loosely light

And quite contrary to her sisters kynd;

No measure in her mood, no rule of right,

But poured out in pleasure and delight;

In wine and meats she flowd aboue the banck,

And in excesse exceeded her owne might. (II.ii.36.2-7)

Medina as a mean between indulgence and recalcitrant abstinence, where "[o]ne thought her cheare too litle, th'other thought too mutch" (II.ii.34.9), is thus established as a theme for Spenser's study of temperance.

\section{The mean and economics}

As canvassed briefly in the introduction, there is also an economic argument for the Elizabethan concern with excess in consumption, one to do with an increasing import of material goods and the need to support English sources of production. Overconsumption is often associated with enervation, and a corresponding loss of the capacity to labour. Joshua Scodel reads the Bower of Bliss episode of FQII in terms of the contrasting treatments of the "hard" and "soft" versions of the country life in Virgil's Georgics and the Elizabethan preoccupation with idleness (Scodel 81-3). "Spenser presents true temperance in 'hard' georgic terms as a laborious struggle against the dual excesses of the self and the external world. He opposes it to a 'false' temperance, conceived in 'soft' georgic terms as harmony with a beneficent nature" (84). When Spenser has Guyon destroy the "soft" Bower of Bliss he is, in Scodel's view, essentially 
concerned with the moral destiny of Britain and a morality developed in the face of adversity. The "temperate" climate of the Bower thus becomes suspect (85).

Those who preached moderation in the period did not necessarily practise it themselves. Burghley condemned the extravagance of the practice of wearing elaborate and heavily starched ruffs, (a practice which supported industries to grow wheat and produce starch and metal poking sticks, as Joan Thirsk explains (Thirsk 88)), arguing that the wheat required to starch a ruff "would staunch the hunger of many that starve in the streets for want of bread" (Graves 160). At the same time, Burghley spent a fortune entertaining the Queen, as did the courtier preferred by Spenser, the Earl of Leicester.

While all the aspects of the mean and extremes described so far in relation to FQII will, as we will see, resonate with Hamlet, there are some further political dimensions that belong particularly to Hamlet, or arise from the period subsequent to the publication of $F Q I I$. These have to do with the difficult years of the 1590 s, as the Queen with increasing ruthlessness suppressed all public discussion of the issue of her succession and of further reform of the church. The first is the concern, described by Patrick Collinson, that the wisdom of the old will not contain the recklessness of the young, that the suppression of wise heads like Grindal (who argues to the Queen that prophesying will, by strengthening the individual conscience, essentially strengthen support for the monarch) will lead to the very thing it seeks to avoid, the rise of the Puritan faction.

Collinson cites a strongly "forward" Job Throckmorton in a speech in Parliament in 1586.

But alas ye see when gray heares grow sylent then younge headdes grow venterous... When they that shoulde speake bee muette then burst out they that shoulde be stille. It is wondred at above, that simple men of the countrey shoulde be so forwarde, and it doeth amaze us in the countrey that wise men of the Courte should be so backeward. (Collinson, Elizabethans 69)

The two issues that Throckmorton wants discussed by the "gray heares" are the reformation of the church and the succession, the "verie pillers and grounde workes of all our blisse and happiness, and without the which...dreadefull despayre will bee the end of our foolishe hope," (ibid), but these are the very topics precluded from discussion by the Queen. The recklessness of the young is most shockingly displayed in the behaviour of Essex, with the famous examples of his bursting in on the Queen before she was properly dressed, and his placing his hand on his sword when she had crossed him, and the ultimate act of rebellion, the attempt to raise the 
people against her. Michael Graves, in his study of Burghley, argues that after the rise of the Earl of Essex the previous checks and balances in the court break down. As the earl manoeuvred a shift towards a more offensive policy in the mid-1590s, the Cecils 'in an uncharacteristically imprudent manner manipulated supplies and information' in order to thwart him (Graves 203).

The increasingly autocratic behaviour of the Queen, combines with this failure in the checks and balances of the "mixed" or temperate constitution. Archbishop Whitgift hardens ecclesiastical resistance to reform and the reformers become embattled. Andrew Hadfield sees a consequent interest in a covert republicanism, and lists the following reasons as those given more openly in the 1590s in support of the mixed constitution: "the need for counsel, for monarchs to obey the law, reason to be the key principle of government, the fear that tyranny will erode the people's liberty and the concomitant fear of rebellion if a monarch treats subjects too harshly, the hope that religious differences can either be solved or placed to one side, and so on" (Hadfield 2005 93). Hadfield reads the central concern of Hamlet as "the dilemma of how they would act when faced with an unjust and unpalatable succession, leaving them governed by a ruler who has obtained power by nefarious means" (203), in other words the topic of succession so strongly prohibited by Elizabeth, and this concern as one more easily addressed through a play about a country whose "mixed" constitution included an elected monarchy. We must note that the issue of a "mixed" constitution belongs naturally in a treatment of temperance.

It is also worth noting that in Plato's Republic the varied forms of government also represent the internal governance of the self. Hamlet alludes to a range of forms of government - a monarchy sanctioned by divinity, a monarchy that arises from election by an oligarchic ruling elite, the need to take account of the will of the people (as in Claudius's inability to act against Hamlet), rebellion by the people in Laertes' attempted coup, and finally what Hamlet regards as Claudius's tyranny. Each aspect of governance displays political failures of temperance.

\section{Hamlet: "whott desyre" and "dolefull tene"}

Act 1 Scene 2 of Hamlet plays both with the mean and with the conflicting demands of "whott desyre" and "dolefull tene," and thus in a very similar way to Spenser announces temperance as a central concern of the action to follow. Claudius opens the scene by announcing that it befits "us," presumably both Claudius and his wife and the kingdom, "[t]o bear our hearts in grief, and our whole kingdom / To be 
contracted in one brow of woe" (1.2.3-4). But in this highly Machiavellian and cynical speech, "discretion" has fought with "nature" (1.2.5). This is deeply ambiguous. Discretion should go with what is befitting, but in this case it would be an act of discretion to go on mourning. It is then against "nature" that discretion operates. If this is so, then it must be both natural and befitting to mourn for a reasonable period. Claudius has had to fight the natural instinct of both himself and his court to act more discreetly. This discretion involves thinking of "ourselves" (1.2.7) with a wise sorrow. The heavy ironic undertow of this speech, the undertow of interpretation open to a listener like Hamlet, is that the battle with discretion has been lost in favour of nature, though not the nature that makes it natural to mourn with appropriate decorum for a decent season, but another natural desire that might lead us to remember "ourselves," and so to marriage in an inappropriate season of mourning. And this is the basis of the divide between Hamlet and the newly married Claudius and Gertrude in the rest of the scene. Spenser's Guyon argues that it is a "thrise happy man" who fares between "whott desyre" and "dolefull tene." Claudius also pronounces a path between this Scylla and Charybdis. His marriage to Gertrude measures in equal weight "delight and dole" (1.2.13), and so makes a series of mixtures of unlikes: a "defeated joy" (1.2.10), "one auspicious and one drooping eye" (1.2.11), "mirth in funeral and dirge in marriage" (1.2.12). Claudius then shores up his very slippery and murky combination of personal and political motivation by implying that he is himself a mean between two extremes of impatience and impotence. Claudius, by this hasty and necessary political marriage, has saved the state from appearing "disjoint and out of frame" (1.2.20), from a political version of the internal disintegration we saw in the previous chapter in the grieving Amavia.

Young Fortinbras holds, Claudius announces, a "weak supposal of our worth" (1.2.18), and has taken the opportunity to press his claim for forfeited land. This young Fortinbras has already been sketched in the previous scene. He is "of unimproved mettle hot and full" (1.1.96), and aims to "recover of us by strong hand / And terms compulsatory those foresaid lands / ...by his father lost" (1.1.102-105). His enterprise is portrayed as essentially reckless and based on the use of a mercenary force. He has "in the skirts of Norway here and there / Sharked up a list of landless resolutes / For food and diet to some enterprise / That hath a stomach in't' (1.1.97-100). This young Fortinbras has elements of both Sansloy and Huddibras. That he challenges an exchange of land that has hitherto been seen as legitimate makes him lawless. Sansloy is: 
...the most unruly, and the boldest boy,

That euer warlike weapons menaged,

And all to lawlesse lust encouraged

Through strong opinion of his matchlesse might:

Ne ought he car'd, whom he endamaged

By tortious wrong, or whom bereaved of right. (II.ii.18.3-8)

But Huddibras is also seen in terms of rashness. He is:

...an hardy man,

Yet not so good of deedes, as great of name,

Which he by many rash aduentures wan,

Since errant armes to sew he first began;

More huge in strength, then wise in workes he was,

And reason with foole-hardize ouer ran. (II.ii.17.2-7)

Young Fortinbras combines both elements, a preference for fighting over more peaceful methods of legal resolution, and a foolhardiness that overcomes reason.

Both aspects can be seen in Claudius's own more subtle actions, in the questionable nature of his ascension to the throne and the implicit forcefulness with which he has overcome what, from Hamlet's perspective at least, might be a more rational approach to the question of succession. Claudius has forced the point and taken the day.

He has done this by styling himself as reason. It is not until late in $F Q I I$ that we encounter the two hags, Impatience and Impotence, who oppose temperate action; in Hamlet they are introduced in the beginning. Young Fortinbras epitomises impatience, leading to a corresponding "post-haste and rummage" (1.1.106) in Denmark, and what might be seen as the post-haste and rummage of the subsequent royal marriage, the need for which has been contrived by this post-haste and rummage. Fortunately, as he styles it, Claudius stands between such impatience and an impotence that fails to control it as the desirable mean of reason. Old Norway, Fortinbras's uncle, is "impotent and bed-rid" and "scarcely hears" (1.2.29-30) of his nephew's purpose, but Claudius's decisive intervention will lead to Norway's suppression of "the levies, lists and full proportions" (1.1.31-32) of young Fortinbras. So that the meaning of his role as the rational mean between impotence and impatience is not missed, Claudius then moves to address Laertes with "you cannot speak of reason to the Dane / And lose your voice" (1.2.44-45). In one neat movement, Claudius has now not only declared "l'état c'est moi" and that he is now 
officially "the Dane" and so regally stands for Denmark, but that he also stands as “reason.” Reasonably granting Laertes' request for leave, Claudius is now poised to make Hamlet look less than reasonable, as a conservative force and a recalcitrant, but in his own way reckless Huddibras figure standing against necessary political expediency.

As Claudius has already said that the royal marriage was a consequence of a battle between "discretion" and "nature", and that it was in fact more naturally "befitting" for the brow of the country to be contracted into woe, Gertrude's initial path of attack on Hamlet's mourning is redolent with hypocrisy from the first, the hypocrisy deriving from the victory of nature over discretion on her own part. The path of attack is in part a Stoic one, that Old Hamlet's death accords with nature: "Thou knowst 'tis common, all that lives must die, / Passing through nature to eternity" (1.2.72-73). Hamlet is cast as both going against reason by going against nature and going to an emotional extreme. By still grieving, Hamlet is cast as the enemy of both Claudius (in his newly established role as "the Dane") and the national interest. Hamlet should "let [his] eye look like a friend on Denmark" (1.2.69), rather than as (with quite strong and threatening implications) an enemy opposed to it, and as someone (more awkwardly and inconveniently) who also opposes the social decorum of the moment at court.

The opposition between the two camps mirrors that between Spenser's Elissa and Perissa, where "one thought her cheare too litle, th'other thought too mutch" (II.ii.34.9). The opposition is in some ways a suppressed one, like Spenser's metaphor of an inward grief of discord between the two sisters "as doth an hidden moth / The inner garment frett, not th'vtter touch" (II.ii.34.7-8). But the opposition must also have had a strong iconographical force on Shakespeare's Elizabethan and Jacobean stage, where, as Roland Frye tells us, the costumes were bought from the discarded wardrobes of the nobility, and Claudius and Gertrude were in all probability presented in luxurious wedding finery as opposed to Hamlet's "inky" (1.2.77) mourning cloak (Frye 88). If in fact Hamlet wears, as Frye argues, the long black robe worn by mourners at a funeral procession, (94) then continuing to wear this cloak after the funeral would amount to a deliberate and conscious pose of dissonance with the decorum of the court, an oddity of behaviour either intended to provoke or revealing a real disorder, arising from grief, that has disrupted normal social conventions of behaviour. In either case this is going to extremes in the face of social decorum. 
There are other explanations for the emblematic blackness of Hamlet's clothes. The most probable one is that they are the clothes of the scholar who yearns to return to Wittenburg. In this case Hamlet's black clothes associate him with reason. Guyon's Palmer in FQII, explicitlyế identified in the text as Guyon's "reason," is represented emblematically through his "black attyre." Devotion to learning is one of the virtues associated by Aquinas with temperance. The scholar in black is potentially threatening to the court in several ways. His scholarship enables him to see things from a different viewpoint (a point already made in the play, as Horatio is assumed to have ways to speak to the ghost the soldiers do not). His black cloak may associate him with a Puritan extreme of denial, and so he becomes a point of conflict with the habits of luxury of the court. His association with Wittenberg may be medieval and Catholic and suggest Dr. Faustus, but it also evokes the roots of the Reformation. Hamlet's orientation to Wittenberg contrasts with Laertes' desire to return to Paris, about which no mention of study is made. The references to Wittenberg and Paris in themselves suggest the opposed Protestant and Catholic camps of Northern Europe at the time.

Hamlet's behaviour is being cast as extreme against a relative mean. This mean has been styled as a rational one, one that has been presented as determined by political expediency - an expediency that may be genuine, but that has nevertheless disrupted a previously socially agreed pattern of behaviour. Claudius presents a case for Stoic apatheia that amounts to a stereotype of this philosophy.

For what we know must be, and is as common

As any the most vulgar thing to sense,

Why should we in our peevish opposition

Take it to heart? Fie, 'tis a fault to heaven,

A fault against the dead, a fault to nature,

To reason most absurd. (1.2.98 -103)

Hamlet's grief is thus categorised as irrational, as lacking in prudence as well as lacking in piety. The roots of his identification with scholarship are also attacked, as Hamlet shows "an understanding simple and unschooled" (1.2.97). A philosophical gauntlet is in other words thrown down in this speech. As previously discussed, to see things in a Stoic way proves in fact very seductive for Hamlet, as his immediate desire for suicide makes clear. But Hamlet chooses a Christian world- 
view, if only one of prohibition. The Everlasting has "set his canon 'gainst selfslaughter" (1.2.131-132) in a way that Stoic apatheia does not.

Hamlet's view of Gertrude's hypocrisy is built around her different approach to grief and joy. On the one hand, Gertrude can exhibit such stoic detachment from grief that "a beast that wants discourse of reason / Would have mourned longer" (1.2.150-1), and on the other hand she was so loving to Hamlet's father that "she would hang on him / As if increase of appetite had grown / By what it fed on" (1.2.143-5). Gertrude is, in Hamlet's view, very like Spenser's Perissa, who is “of her loue too lauish" and who has "[n]o measure in her mood, no rule of right, / But poured out in pleasure and delight," (II.ii.36.4-5). All these Perissa-like behaviours are neatly contained in despairing description of Gertrude posting "[w]ith such dexterity to incestuous sheets" (1.2.157). As Horatio enters, Hamlet's language moves from the intemperance of sexual lust to the intemperance of food and drink. Elsinore can educate Horatio by teaching him to drink deep ere he departs, although ironically the reason of his mother's hasty marriage was thrift: "The funeral baked meats / Did coldly furnish forth the marriage tables" (1.2.180-1).

As the play develops, Hamlet, not unlike like Spenser's Elissa who "ne ought would eat, / Ne ought would speake, but euermore did seeme / As discontent for want of merthe or meat" (II.ii.35.2-3), allies himself strongly with the extreme of less and against the customs of the kingdom used to doing things to excess, traditions seen in the firing off of cannons with each drinking bout. There is a strongly political aspect to Hamlet's opinions about excess in the consumption of alcohol. The reputation of the Danes for drunkenness spoils any positive views of their strengths, and so excessive drinking undermines the state. That Old Hamlet was poisoned by Claudius when he was "full of bread" (3.3.80), and his sleeping off of overindulgence in the orchard also reinforces the sense of a country undermined by its excesses - precisely the kinds of excesses denounced by the Elizabethan homilies. His overindulgence and reprehensible (for the period) consequent sloth, in other words, has left him exposed to attack. Intemperance in this sense has weakened the country. Old Hamlet's death in a garden, as well as the Eden already described, also carries connotations of the Epicurean Garden. The temperateness and equanimity of such a garden of pleasure has already been evoked when Hamlet describes his father as "so loving to my mother / That he might not beteem the winds of heaven / Visit her face too roughly" (1.2.140-2). The combined characterisations of Old Hamlet, Claudius and Gertrude point to a Denmark in the thrall of a variant of Spenser's 
Perissa, who has no measure in her mood, " [b]ut poured out in pleasure and delight; / In wine and meats she flowd aboue the banck, / And in excesse exceeded her own might" (II.ii.36.5-7). An excess of death as a feast by which the kingdom is ultimately judged on the final entry of Fortinbras - "O proud death, / What feast is toward in thine eternal cell / That thou so many princes at a shot / So bloodily hast struck" (5.2.343-346) - follows naturally from this introduction to excess in the play's early scenes. Hamlet's political unease at the moral excesses of his kingdom is, to this extent, justified in the event.

The archetypal model of single combat between Old Fortinbras and Old Hamlet, set up in the first scene of Hamlet, becomes, I would like to suggest, in the second scene of Hamlet, an action of single combat between opposed views of what is reasonable, and this in turn is a battle for the moral health and the political stability of the kingdom. Hamlet tells Horatio that he would rather have met his dearest foe in heaven than seen the day that his mother married his uncle (1.2.182-3), and this establishes one extreme of judgement. The other extreme is established by Claudius's rationale for the haste of the marriage, that without it, the kingdom would be "disjoint and out of frame" (1.2.20). Spenser's Bower of Bliss provides the model for an epicurean duplicity in Claudius's argument. Claudius establishes motivations that are reasonable, and their tenor is that in re-establishing rational control he brings a temperate stability to the kingdom, overcoming both impotence and impatience. But the arguments are flimsy, and in their slippery language scarcely attempt to disguise the motivations of personal indulgence in power and physical pleasure that are the consequence of the political move. Hamlet's recalcitrance bursts into the temperate harmony of Claudius and Gertrude's political compromise, and disrupts its promise of comforting peace with a jarring and indecorous note of disharmony. Just as Guyon and his Palmer move through the Bower of Bliss attacking its parts and finally its whole, Hamlet's discord finally destroys the careful but duplicitous structure erected by Claudius, a structure whose false foundations have nevertheless been apparent from the first. From the perspective of Claudius and Gertrude, Hamlet's opposition smacks of a sanctimonious resistance for its own sake (somewhat like Guyon's progress through the Cave of Mammon), an over concern with principle at the cost of the harmony of the whole, a looking for the wrong at the expense of embracing a wider interest: the kinds of difficulties, in short, associated by the establishment of the Elizabethan court and church with "forward" parties looking for reform of state and church. The minor characters in the play reinforce the nature of the extremes of the 
court and the conflict between Claudius and Hamlet; Laertes seeks for occasions for pleasure, and Fortinbras for occasions for war.

Claudius's weapon of choice in the conflict that develops into the play is the appearance of equanimity and rational self-control. "The Dane" continues to be "reason." Hamlet uses the weapon that has been given to him, an opposed view to the consensus of the ruling party transformed into an irrational extreme. He attacks with a series of breaches of social decorum opposed to temperance. To emphasise the point, rules of decorum are provided to Laertes by Polonius, and they include the injunction to moderation in dress, familiar now through the discussion of the moderate dress of Medina and the opposed extremes of Elissa and Perissa: "Costly thy habit as they purse can buy, / But not expressed in fancy; rich, not gaudy. For the apparel oft proclaims the man" (1.3.70-2). While Seneca is often given as the source for this clear reference to the mean, I will offer the Cicero to whom I have previously referred. "We must besides," argued Cicero in De Officiis, "present an appearance of neatness - not too punctilious or exquisite, but just enough to avoid boorishness and ill-bred slovenliness. We must follow the same example in regard to dress. In this, as in most things, the best rule is the golden mean" (133; I.xxxvi.130). Hamlet's appearance to Ophelia goes deliberately in the opposite direction: "[W]ith his doublet all unbraced, / No hat upon his head, his stockings fouled, / Ungartered, and downgyved to his ankle" (2.1.76-78). Attacking in Ophelia the injunction against cosmetics (strongly associated with intemperance in Patristic writing and in Aquinas and an undoubted play on the theme of temperance recognisable as such for an Elizabethan audience), he says, "God hath given you one face and you make yourselves another" (3.1.137-8), breaking all the rules of acceptable social discourse. We have, argues Cicero, "a most excellent rule for every phase of life, to avoid exhibitions of passion, that is, mental excitement that is excessive and uncontrolled by reason; so our conversation ought to be free from such emotions: let there be no exhibition of anger or inordinate desire... We must also take the greatest care to show courtesy and consideration toward those with whom we converse" (139; I.xxxviii.136).

Cicero does allow for occasions for reproof. "On such occasions we should, perhaps, use a more emphatic tone of voice and more forcible and severe terms and even assume an appearance of being angry." This sort of approach, however, should be very rarely used. "We may seem angry, but anger should be far from us; for in anger nothing right or judicious can be done. In most cases, we may apply a mild 
reproof, so combined, however, with earnestness, that, while severity is shown, offensive language is avoided" (139; I.xxxviii.136-7). Hamlet's approaches are insulting to the point of cruelty to Ophelia and later his mother; the bawdy jokes at Ophelia's expense at the watching of the "Mousetrap" play demonstrate another example of a strong breach of social decorum condemned by Cicero (and citing Cicero directly in the Summa Aquinas [2a2ae.168.3]). Some jokes are unfitting for any gentleman "if the subject is indecent and the words obscene" (Cicero 107; I.xxix.105). By contrast, the apparent reasonableness of Claudius and Gertrude is accentuated to the point where they become the norms for social and moral behaviour in the play. What further complicates our view of means and extremes in Hamlet is that Hamlet's strategic lapses of decorum become difficult to untangle from less strategic losses of control. Temperance as a desirable quality of the state, and temperance as personal self-control, thus become intertwined in a series of complex ways in the development of the play. In Spenser the presentation of the mean is followed by a treatment of rational self-control challenged by intemperance in the pattern of the Platonic model of the tripartite soul, of reason, irascibility and concupiscence. Temperance and intemperance unfold in a similar pattern in Hamlet, and to this more "inward" and psychological way of looking at temperance we will now turn. 


\section{Chapter Seven: 'Towering passion,' rational self-control and conflict in the soul}

In the final scene of Hamlet, Hamlet expresses regret to Horatio about one of his emotional lapses in the play, "[t]hat to Laertes I forgot myself" (5.2.77). It is clear nevertheless that part of him still clings to the reason for that forgetting of self, as a sufficient explanation for loss of rational self - "But sure the bravery of his grief did put me / Into a towering passion" (5.2.80). In a parallel way to FQII Hamlet is constantly concerned with temperance as rational self-control and usually, as in this example, with the failure of such self-control. This chapter will focus primarily on two sources of the undermining of rational self-control. The first source is the passions of the sensitive soul. The second source is a failure in the intellective soul a failure of the virtue of prudence, an error in judgement and choice.

This chapter will work primarily with the Thomist model of the soul as representative of a range of scholastic models still influencing the late sixteenth century view of psychology. If temperance is to do with emotional self-control, the processes of such emotional control must be addressed. But as models familiar to the period are examined, it becomes clear just how complex such processes can be. This chapter can only begin to hint at some of the processes of conflict within the different parts of the soul addressed by both Spenser in FQII and Shakespeare in Hamlet. The focus of the chapter will primarily be on Canto IV to Canto VIII of $F Q I I$, which trace Guyon's encounter with two foes of rational self-control, Pyrochles and Cymochles (often identified with irascibility and concupiscence), and with the equivalent early and middle sections of Hamlet, up to the ending of Act Three. In Aquinas's system not only is there a set of intricate relationships at work within the tripartite soul, but there is also a complex relationship between this soul and the operation of the cardinal virtues.

Aquinas sees the virtues as dispositions, strengthened internal habits of will. According to the philosopher Eleonore Stump (in the recent study Aquinas), "Habits of will are conditions necessary for our carrying out our volitions in particularly good or particularly bad ways... and the habits that play these crucial roles in Aquinas's moral theory are the virtues and the vices" (Stump 25). When the will is strengthened by habit to respond positively towards the variety of good that may be presented to it by the intellect, its determining activity will follow more promptly, and the desired 
moral action that will lead to the good of the person will be achieved. Stump neatly sums up the roles of the cardinal virtues as habits of the will governed by reason.

Reason's habit of good governance generally is prudence; reason's restraint which wards off self-serving concupiscence is temperance; reason's persevering rather than giving in to self-serving irascible passions such as fear is courage; reason's governance of one's relations with others is justice. (Stump 25)

Thus while temperance is specifically the virtue concerned with concupiscence, and courage (or more traditionally fortitude) is the virtue concerned with irascibility, rational self-control can safely be seen as an aspect of all four cardinal virtues.

Spenser often uses the relationship between Guyon and his travelling companion, the Palmer, and especially in these early and middle cantos, to represent the processes of rational decision-making and the governance of reason. The advantage of allegory, in presenting the inner struggles of the soul, is that the parts of the battle, and particularly the interaction of reason and passion, can be represented by different allegorical characters - we can see those inner struggles acted out for us. Shakespeare, on the other hand (as a dramatist), uses soliloquy to allow us to hear Hamlet describe his internal processes of emotional response and decision making, and most of the characters in Hamlet both display their emotions in outbursts on stage and spend considerable time discussing one another's behaviour and the project of self-discipline more generally. Nevertheless both poet and playwright must be seen as facing some of the same problems as the ethical philosopher or theologian in their attempts to portray what actually takes place in the inner battles for rational self-control.

\section{Temperance and harmony or disharmony in the soul}

Before moving to the dynamics of the battles between the parts of the soul it is worth alluding again to the point raised early in this thesis, that temperance carries a wider set of connotations than just control of the concupiscent aspect of the soul, that it also implies the deeper harmony of rational self-governance, a certain integrity of the self. In the mid-1950s the Thomist philosopher Josef Pieper described temperance as "selfless self-preservation," opposing it to the "selfish degradation of the powers which aim at self-preservation" (Pieper 49). Behind this view of temperance as a virtue that focuses on the inner person lies Pieper's acknowledgement of the earliest Greek meaning of sophrosyne, the one discussed so far in this thesis through the 
work of Helen North as health of the mind (or phrenes). Pieper argues that "the original meaning of the Greek word embraces 'directing reason' in the widest sense. And the Latin stays close to this far-ranging significance" (47). It is to this wider view of temperance as directing reason (or health of the soul) that the association of temperance as a harmony of all the parts belongs. Pieper sees this underlying connotation in the use of temperare in the Pauline Epistles.

In St. Paul's First Epistle to the Corinthians (12:24f.) we read: Deus temperavit corpus. "Thus God has established a harmony in the body, giving special honor to that which needed it most. There was to be no want of unity in the body; all the different parts of it were to make each other's welfare their common care." The primary and essential meaning of temperare, therefore, is this: to dispose various parts into one unified and ordered whole. (47-48)

Pieper sees the most important secondary meaning of temperance for Aquinas as "quies animi" (serenity of the spirit), which he interprets in the following way: “The purpose and goal of temperantia is man's inner order, from which alone this 'serenity of spirit' can flow forth. 'Temperance' signifies the realising of this order within oneself" (48). As a consequence temperance is, of all the cardinal virtues, the virtue that involves the person looking inwards - "his vision and his will should be focused on himself" (48-9). If we accept Pieper's Thomist view of temperance, the preoccupations of both FQII and Hamlet with passions and their interactions with reason and the will - the constant looking inwards of both works - have a clearer internal logic.

\section{The Platonic tripartite soul}

The ideal of temperance as a unity in the soul finds its Platonic roots in the Republic, where temperance is viewed as a type of concord or harmony. "It is a kind of cosmos somehow, and a control of certain pleasures and appetites, as they say when they call someone master of himself in some fashion" (Plato Republic 430e qtd North 172). As Paul is later in Corinthians (above) to use the harmony of the body as an analogy for the body of the church, Plato compares the operation of the state with the functions of the body. When rulers and ruled hold the same view of who should rule the city, this consonance of view demonstrates sophrosyne in the sense of harmonia and sounds "the same note in perfect union throughout the whole" (432a, North 173). The Republic is one source of the Platonic division of the soul into three, into rational, spirited and appetitive parts that find their parallels in the state. Spenser's view of the ideal body in the House of Alma episode which "doth freely yield / His 
parts to reasons rule obedient," echoes this view of Platonic order as a state where there is not just acceptance but willing agreement between ruler and ruled.

The relationship between the three parts of the soul and the cardinal virtues is one of the complications we must deal with as we attempt to understand Spenser's treatment of temperance. Stump, as we have seen above, sees the role of all the cardinal virtues in terms of something like Pieper's “directing reason.” More narrowly, temperance is usually the virtue concerned with the pleasures of touch, and so tends to be associated with the concupiscent aspect of a tripartite soul, while fortitude is associated with the irascible aspect of the soul and prudence with reason. Justice is associated in Augustine with order throughout the soul (and the proper relationship of the soul to God), but often justice is reserved for outward relationships with others rather than the operation of the soul itself. For Plato in the Republic, however, all three parts of the tripartite soul need to demonstrate all four cardinal virtues if the proper order of the soul is to be maintained. To spell this out explicitly, reason must demonstrate wisdom (in this case wisdom rather than prudence), justice, fortitude and temperance; the spirited part of the soul must demonstrate wisdom, justice, fortitude and temperance; and the concupiscent part of the soul must demonstrate wisdom, justice, fortitude and temperance. This view is easier to understand in the analogy of rulers and ruled - the ruled need to demonstrate all the cardinal virtues and so do the rulers. And it is also easier to understand if we see the potential destruction of the harmony of the soul as a consequence of the breakdown of any of the cardinal virtues in any part of the soul. While temperance most naturally controls concupiscence, temperance must be strengthened to operate against concupiscence by fortitude, must be directed by reason in doing so and so on.

What is important to understand here is that the cardinal virtues should not be seen as contained in rigidly defined categories, but in constantly changing dynamic interrelationships (outside the perfection of the divine soul), that inevitably involve the virtues working together (and against varied combinations of the vices opposed to these virtues). Aquinas in the Summa uses the metaphor of "overflow" to show this mutually supportive interaction.

For the qualities of prudence overflow on to the other virtues in so far as they are directed by prudence. And each of the others overflow on to the rest, for the reason that whoever can do what is harder, can do what is less difficult. Wherefore whoever can curb his desires for the pleasures of touch, so that they keep within bounds, which is a very hard thing to do, for this reason is 
more able to check his daring in dangers of death, so as not to go too far, which is easier: and in this sense fortitude is said to be temperate. Again, temperance is said to be brave, by reason of fortitude overflowing into temperance: in so far, to wit, as he whose mind is strengthened by fortitude against the dangers of death, which is a matter of great difficulty, is more able to remain firm against the onslaught of pleasures. (1a2ae.61.4)

As will become apparent, some of the interactions of $F Q I I$ are usefully seen in terms of such "overflow."

In the more mystic Phaedrus, Plato provides a specific model for the interaction of "spirit" and concupiscence. Here the metaphor of the charioteer as reason is used with two horses, one "spirited" (thumike) and one concupiscent (epithumike) (James 56). (James helpfully explains that the Greek thumike becomes the irascibilis of scholastic Latin usage through the translation of William of Moerbeke and it is important to note that the connotations of these two terms are not completely identical.) The spirited horse in Plato's metaphor is more naturally an ally of reason - and it is when the concupiscent horse leads the spirited horse astray, leading it in turn to pull against the charioteer, that the chariot of the soul goes astray. Reason in turn must use the spirited horse to control the concupiscent horse, but when all work together the ascent of the soul to the contemplation of ideal beauty becomes possible. When Aristotle divides the soul into rational and non-rational parts in De Anima, it is the non-rational part of the soul that becomes divided into thumike and epithumike (the later irascible and concupiscible).

\section{Being pulled this way and that by emotions - current philosophy of emotions}

Modern philosophy has found it no easier than Plato, Aristotle, Aquinas and other ethical philosophers of the deep past of the western intellectual tradition to describe what happens when we experience emotions. In fact there is an active division in the way emotions are currently viewed (and some of this debate can be seen in the recent Thinking about Feeling: Contemporary Philosophers on Emotions edited and contributed to by Robert C. Solomon) about how far emotions should be seen in terms of some form of judgement on the one hand, or identified with changes in body state on the other. Approximately the two camps divide between philosophers such as Solomon, who coined the phrase "emotions are judgements," and those who, with reference to current neurological study of the processes of the brain, concur with William James' earlier position that "our feeling of [bodily changes] as they occur IS the emotion" (Solomon 76). 
I intend briefly here to follow the argument of the philosopher Jenefer Robinson in this debate, primarily to contextualise her explanation of the "emotional stream" (Robinson 38). Some of the dryness of Aquinas and much of the interaction of FQII and certain key sequences in Hamlet come into sharper focus when the term "emotional stream" is applied to them. The term helps us make sense of what happens, or at least to understand the process involved - for the problem of understanding how what Robinson designates as affective and cognitive appraisals and reappraisals interact with each other is intrinsically difficult, in part because we cannot rely on the accuracy of cognitive appraisals made when we are in the middle of an emotional stream.

Robinson strikes a compromise position between the positions I have roughly attached to Solomon and James. On the side of the emotions-as-judgement case are the following arguments. First, to be in love or to be afraid of a bear involves judgements about a person we love or the threat the bear presents. Secondly, a change of cognitive evaluation changes our emotional responses - we are angry if we think someone has insulted us, but our feelings will change when we find we misheard them. Thirdly, we argue with people about whether their emotions are justified. And fourthly, emotions (sadness, fear, anger and so on) are distinguished one from the other by evaluative judgements. However, Robinson argues, you can make evaluative judgements without being in the corresponding emotional state and vice versa - for example, you can note that you have been cut off in traffic without getting angry.

On the side of the debate that views feelings of bodily change as the emotion, there is evidence from psychological testing of physiological changes that indicates a process of "affective or non-cognitive" appraisal that occurs very fast and below the threshold of awareness. Such changes have a basis in biological survival and are particularly seen in responses of fear. The problem with this approach to the emotions is that it does not account for the subtle distinctions between more complex emotions such as shame and guilt or jealousy and envy. Drawing on the work of the neurophysiologist Joseph LeDoux and the psychologist Phoebe Ellsworth, Jenefer Robinson presents a form of compromise between the two conflicting philosophical positions, arguing that "even a simple episode of emotion is a process, involving a number of different events, and, in particular, involving both affective and cognitive evaluations." 
As her description of an emotional stream is particularly pertinent to much of the middle section of $F Q \mathrm{II}$ and some key sequences in Hamlet, I cite her scenario here in full.

Suppose Joe, my husband of thirty years, suddenly runs off with a twenty-five year-old model. I will probably be overwhelmed by a stream of different emotions, by different affective appraisals, unpleasant feelings, and a welter of physiological changes: at one point I am raging, at the next crying, at one time I am lethargic, at another manic. I may be confused about what I believe about the situation, and about which wants of mine are most at stake. At one time I think I have been betrayed, at another I am worthless and deserve to be abandoned; at one time I think I have suffered an irretrievable loss, at another that such a scoundrel is not worth keeping. Or I may be barely conscious of thinking anything. In any event I can have only the dimmest of ideas about the sequence of affective appraisals and cognitive reappraisals that actually occurred in temporal sequence. Later, however, when I have had a chance to reflect upon my various emotional reactions I can catalog them in recollection. I can describe my state in terms of the emotional concepts familiar to me in English: I was resentful, grieving, depressed, jealous, frightened and so on. How I catalog this stream of events in reflection is largely a function of the emotional concepts at my disposal in the language and culture that I inhabit. And of course I might be wrong in my assessments. I may decide that my main emotion is resentment, whereas my behaviour, physiological states and facial expressions show that my predominant reaction is best described as grief. (Robinson 38-39)

Robinson's conclusion is that "a cognitive evaluation all by itself is not enough to generate an emotional response; an affective appraisal is required as well" (40). The fast and automatic affective appraisals "instantly produce the physiological responses characteristic of emotion," and this affective appraisal is then monitored by cognitive appraisal and reappraisal. A range of factors might influence the strength of the initial affective appraisal, factors such as whether "the wants and interests that are at stake in an encounter are intensely important to us"; "the vividness of the perception or mental image that prompts the affective appraisal"; and our current bodily and mood state, for example whether or not we are tired, "hyped up on caffeine or under the influence of alcohol" (40). While Robinson is arguing that an affective appraisal always initiates an emotion sequence, "this affective appraisal may itself be an appraisal of some cognitively complex information ('My boss insulted me')" (41). It "can be evoked by a complex learned stimulus just as easily as by a stimulus that is preprogrammed to produce such a response" (42).

What Robinson is describing here is not far from the view of the passions in Aristotle and Aquinas as essentially passive states - that our initial emotional responses happen to us. Robinson herself points the comparison: "[T]he notion of a 
noncognitive appraisal produced automatically and automatically resulting in physiological changes explains why traditionally emotions have been treated as 'passions,' as phenomena that act upon us and are not directly under our control, rather than as 'judgements' that we consciously and deliberately make. Noncognitive affective appraisals are not controllable except indirectly" (43). In other words, Robinson's portrayal of an emotional stream is a helpful bridge between Aquinas's categories and the sequences of FQII and Hamlet - it helps us think our way into these categories as processes that happen in real life. "Modern students of the Renaissance are often amazed," Judith H. Anderson notes in her essay "Patience and Passion in Shakespeare and Milton", "to discover that relation of passion to passivity inhering in the traditional conception of passion as something that happens or is done to you, and that you control by reason, or not" (207). Robinson's contemporary philosophical approach to the emotions, and behind it, the work on the biological processes of the brain core, blurs such disjunctions between the traditional and contemporary views of emotions.

When Hamlet steps out from hiding and challenges Laertes over Ophelia's grave we are warranted in seeing his sequence of responses in terms of the intemperance that is loss of rational self-control by three things: by his own later self-report that he "forgot himself" and that the bravery of Laertes' grief put him into a "towering passion" (5.2.76-79); by Claudius's judgement, "Oh he is mad Laertes" (5.1.239); and by Gertrude's description of the sequence as a "fit" that is working upon him and will come to a natural end: "Anon, as patient as the female dove / When that her golden couplets are disclosed, / His silence will sit drooping" (5.1.253-4). Gertrude is claiming privileged knowledge of Hamlet's behaviour, as though this type of emotional stream, concluding with dejected silence, is something she has seen in Hamlet before. We can accept or fail to accept any of these three evaluations of Hamlet's behaviour. What Jenefer Robinson's careful philosophical discussion of the nature of an emotional stream allows us to see is just how difficult it is to describe at all accurately what is involved in such a sequence of behaviour driven by emotion. For example, it is difficult to tell what triggers Hamlet's emotional response to Laertes - love for Ophelia and so grief, pique, irritation at Laertes' hyperbole, an underlying guilt, calculated histrionics, or something else. We can only guess, and if we apply Robinson's modern psychological and philosophical argument to Hamlet, it is likely Hamlet could not articulate the emotions accurately 
himself even if he attempted to describe them. We are dependent on report and action to form our own judgements.

What we do see are the rapid shifts of the emotional stream, Hamlet's initial challenge to Laertes, his bold self-disclosure - "This is I, / Hamlet the Dane" (224-5) - as well as the fighting that includes a direct threat of harm ("Yet have I in me something dangerous / Which let thy wisdom fear" (229-30)) and defiance to the Queen: "Why, I will fight with him upon this theme / Until my eyelids will no longer wag" (233-4). There is also the claim of his love for Ophelia, his return to attack Laertes ("What wilt thou do for her?") and then the ranting tirade, "Woo't weep, woo't fight, woo't fast, woo't tear thyself? / Woo't drink up eisel, eat a crocodile?" (242-3). This speech sounds irrational on one level; on another it is merely sardonic, a mocking extension of Laertes' hyperbole of language and through this sarcasm an attack on Laertes' sincerity. Or, as Robinson argues for such emotional streams, some complex combination of affective and cognitive processes is at work. The emotional storm of the speech finally dies away to the quieter appeal - "What is the reason that you use me thus? / I loved you ever" (256-7). We are left puzzled about the balance of rationality and irrationality in this interchange as well as its inner nature, and when Hamlet later describes the sequence to Horatio we cannot be sure that, as in Robinson's scenario, he has more than the "dimmest of ideas about the sequence of affective appraisals and cognitive reappraisals that actually occurred in temporal sequence."

As we turn to rational self-control through the lens of Thomist ethics we must take with us Robinson's insight into the difficulties of pinning down the nature of the emotions that reason would strive to control - that the processes Spenser and Shakespeare attempt to convey do not, even today, easily yield up their nature to rational investigation.

\section{The passions of the sensitive soul in Aquinas}

Let us move now to ways of describing this sort of emotional stream more familiar to the late sixteenth century. Following Aristotle, Aquinas divides the soul into rational and non-rational parts (or souls), the intellective and sensitive souls. The sensitive soul is divided into irascible and concupiscible appetites. To complicate things further, the intellective soul (unlike that of Aristotle) now includes not only intellect but also the will or rational appetite of Christian ethics. The intellect is concerned with universals, and the intellective appetite or will is an inclination to pursue good 
and avoid evil, responding not to sensible good and evil but to ultimate ends of truth and goodness. The sensitive soul can only apprehend particular things.

Eleonore Stump characterises the irascible and concupiscent appetites of the sensitive soul as the competition/aggression/defence appetite and the pursuit/avoidance appetite, and in Aquinas the eleven passions of the soul are divided between them (21). "As well as introducing a certain toughness into the passions," argues the philosopher Susan James, “[Aquinas's] division between the concupiscible and irascible appetites aims to create space to deal with conflict in the soul" (James 58).

There are six passions in the concupiscible appetite, and we feel these passions if there is no obstacle in the way. It is in this way that they are like the concupiscent horse of Plato's myth of the charioteer which readily follows its own inclinations as if anticipating no opposition. These six passions are love, desire, joy, aversion, hatred and sorrow. If there are no obstacles in the way of the inclination to good, the appetite begins with love and this leads to a movement of the soul towards the thing desired; this movement is desire, which culminates in joy. If we see something as evil, hatred leads to avoidance, to a movement away from the thing in question (a movement that is the negative of desire) and finally to the pain of sorrow if avoidance fails. The five irascible passions - hope, despair, audacity, fear and anger - come into play when there is an obstacle or uncertainty. To be attracted to something difficult to attain is to hope. To be repelled by the good is to despair. Audacity is the inclination towards a threatening evil, fear an aversion to the threatening evil. Anger is the inclination to resist such an evil, and for Aquinas anger or ira carries the connotations of aggressiveness or resolution (James 57).

Once the division of the sensitive soul is increased from two to eleven the potential combinations for conflict increase even more dramatically. The concupiscible and irascible passions can combine in a variety of ways. The concupiscible passions themselves may be opposed, and James gives the example of someone both liking and not liking a painting. The concupiscible and irascible may be opposed to each other, as in a ruler who inspires both love and fear. The concupiscent desire to stop working can be overcome when ira, an irascible passion, strengthens the desire to keep working. For Aquinas, the passions always occur in sequences, and these sequences always begin and end with concupiscible passions. They begin with either love or hatred, which leads to desire or aversion. At this point a range of possibilities opens up. If the goal is desired, but whether or not it will be 
reached is uncertain, the consequent passion may be hope. If the goal is surrounded with obstacles the next passion aroused may be ira. Whatever the following combinations, the ultimate conclusion must be either joy or sorrow (James 58).

In other words, we must see the potential for conflict in the soul as happening not just between the rational, intellective soul and the irrational, sensitive soul (reason attempting to control passion), but also within the sensitive soul itself. Because placing the passions in the sensitive soul makes them part of the body-soul composite, they are always associated with some form of bodily change (anger as a boiling of blood around the heart), of "both feelings identified as love, envy, hope and so on, and of bodily changes to which these are essentially related" (James 56). In this way they are like the affective appraisals of Jenefer Robinson. It has been the work of recent studies of the body and the humours in Early Modern writing by Michael Schoenfeldt and Gail Kern Paster to remind us of the importance of the manifestations of such bodily changes.

As we have already seen, the passions are also passive in the Aristotelian and Thomist systems - they happen to us, and this makes them hard to control. "Faced with a cherry tree in full leaf," James explains, "it is not in my power to perceive it as orange rather than green. Similarly, Aristotle seems to be saying, when someone insults me it may not be in my power to feel forgiving rather than angry" (James 42). Because the passions produce physical as well as psychological effects, emotions such as anger are hard to overcome even when one tries to "calm down," and for this Aristotle used the analogy of being unable to get a tune out of your head (James 42). We must now add the disembodied intellective soul to this picture of the relationship of the body-soul composite.

\section{The intellective soul, reason and the will}

As we add to the potential conflict between the passions (and so within the sensitive soul), the complex interactions between the intellective soul and the sensitive soul, and also within the intellective soul, we are multiplying again the potential sources of any moral action going astray. Aquinas, as we saw at the beginning of this chapter, sees moral virtue in terms of habits of the will. As the sensitive soul produces passions, the intellective soul produces rational appetites or wishes that move people to rational action. While the passions of the sensitive soul do not affect the judgements of the intellective soul directly (because they are corporeal and the intellect is incorporeal) they operate to do so indirectly in two ways - by working 
through the internal senses of imagination and the somewhat mysterious cognitive power (which discerns particulars rather than universals and prepares phantasms for the intellect, judgements based on particulars which can be taken up by the intellect). The passions (as Robert Pasnau in Thomas Aquinas on Human Nature puts this) distract the will from its own operations; they "literally do just distract us from thinking clearly and putting matters into the proper perspective" and also "[i]n affecting the imagination, the passions affect the kinds of images we have in our head" (253). Because of the very materiality of the sensory appetites they can never be fully controlled.

Reason operates to control the sensory appetites through the cognitive power, by directing particular reasoning through universal reason. It also controls the passions through the will. "Even if the sensory appetites get out of control, they still cannot produce any action unless the will consents" (Pasnau 258). Because imagination is "to some extent under the mind's control" (258), it can also lead to control over the sensory appetite. But for Aquinas (as more strongly for Augustine and Protestant thought) the only ultimate source of action against the power of the passions to lead reason astray is the gift of grace (260).

Aside from the passions there are two other potential internal sources of immoral behaviour or sin in the Thomist system: malice (when the will loves more what is less good) and ignorance, a failure of reason. Aquinas views intemperance (as opposed to incontinence which involves a temporary suppression of knowledge of what is right) as a "species of malice," the deliberate and habitual choice of something known to be wrong. Pasnau argues that "for Aquinas, a large part of immorality is the result of failing to act on what we know 'in our hearts' we should do" (249). The incontinent person may fall victim to the problem of impetuosity, giving in to the passions without reasoning at all, or of the weakness of inconstancy, knowing the general principle that no sin should be done but not identifying sin with the particular pleasure to be pursued in a particular case. Incontinence is thus a species of weakness of will (in the sense of the akrasia of modern philosophy). Intemperance is a much more serious proposition.

The incontinent person has in their mind two simultaneous propositions, that no sin should be done, and that every pleasure should be pursued. In the case of an individual occasion of both sin and pleasure, and under the pressure of passion, the first general principle remains but is not followed by the conclusion that "this is a sin, therefore this should not be done." Only the alternative conclusion - "this is a 
pleasure, therefore this should be pursued" - is followed into action. But later, in reflection, the first set of conclusions returns to the mind and leads to regret and guilt. The intemperate person more seriously "is not swayed by passion but chooses the side of the passions, without regret" (Pasnau 247); he either fails to know or has in some way successfully suppressed his knowledge of the underlying principle of virtue (no sin should be done), and it is in this way that the actions of the intemperate person are more strongly associated with the sensitive appetite than those of the incontinent person, while the actions of the incontinent person (counter-intuitive as this may be) is more closely associated with the will.

\section{Prudence of the flesh and the vices opposed to prudence}

It is in the vices opposed to prudence in Aquinas's Summa Theologiae that we see many of the problems with rational self-control that Shakespeare presents in Hamlet, and again as we examine this intellectual virtue, associated primarily with the intellective soul, we multiply the potential sources of any wrong moral choice. It is helpful to the application of these aspects of prudence to specific cases in $F Q \mathrm{II}$ and Hamlet to describe them in general terms to begin with, and so provide some sense of their interlocking nature.

Prudence is divided by Aquinas in the Summa Theologiae into eight parts (63; 2a2ae.49,1). It includes the cognitive aspects memory (memoria), understanding, insight or intelligence (intellectus or intelligentia), docility or teachableness (docilitas), shrewdness or acumen (solertia or eustochia), and reasoned judgement or reasoning (ratio). The three remaining aspects command and apply knowledge to action and include foresight or prevision (providentia), circumspection (circumspectio) and caution (cautio). It is through intuitive understanding or insight (the gift of the Holy Spirit) that the general moral principles that need to be grasped and their correct application to particular circumstance occur. Prudence "applies the knowledge of general principles to the particular incidents with which the senses are occupied", and so memory, one of the aspects of sensory psychology, becomes an essential part of this process (63; 2a2ae.49,1). Docility or teachableness is required because the particular matters with which prudence deals "are infinite in their variety, one person alone cannot consider them all sufficiently" (69; 2a2ae.49,4). While the process of good counsel can happen slowly, shrewdness is required when a choice needs to be made without warning. 
Reasoning is necessary as people cannot intuit things in the way possible for angels, because "the field of prudence is composed of particular things to be done," and these are consequently less certain and determinate (75; 2a2ae.49,6).

Circumspection is required because "it may happen that a means good and suitable in the abstract becomes bad and inopportune owing to a combination of circumstances" (79; 2a2ae.49,8). Aquinas gives the example of the suspicion of flattery or pride overriding an initial response of love. Caution is needed because in contingent actions "rights are often entangled with wrongs, and wrongs wear the air of good" (81; 2a.2ae.49,8). Foresight allows us to set means in due order towards an end, and in this sense is central to prudence and allied with the idea of providence, the application of universal truths to practice - for which reason it requires rightness of counsel, judgement and of command. As we have seen, a good disposition of the appetitive power or will is required for prudence, and it is essential that true ideas are not distorted ones - and it is this aspect of prudence that is the gift of grace.

The wicked person may show a right judgement of a universal principle but corrupt judgement in a particular matter of action. Things may also go astray when the judgement itself is right but its execution delayed or executed negligently or inordinately. And then there may be failures of any of the aspects of prudence just listed. Lack of memory, docility and reasoning lead to precipitous action (praecipitatio), the rashness that is a vice of imprudence linked to a failure of fortitude. Defects in judgement, intelligence and shrewdness lead to inconstancy (inconstantia), thoughtlessness (inconsideratio) and negligence (negligentia) (121; 2a2ae.53,1). The system continues in this elaborate way, of which one example may suffice at this point. Instead of rushing in, one ought to descend in an orderly fashion through "memory of the past, insight into the present, shrewdness in attending to future results, reasoning in connecting one thing with another, docility in accepting the judgements of those more experienced: to go down the scale in regular fashion one has to be well-advised. But if one is driven to action by an impulse of will or passion to rush these steps he will be foolhardy and hasty" (129; 2a2ae.53,3).

One category of vices associated with prudence is particularly important for Spenser's treatment of the Cave of Mammon and Shakespeare's treatment of Claudius. This is the category of vices opposed to prudence by way of resemblance. Prudence of the flesh is the prudence of the person who looks upon carnal goods as the last end of their life, and this is a mortal sin if it entails turning away from God $(151 ; 2 \mathrm{a} 2 \mathrm{ae} .55,2)$. Craftiness or cunning (astutia) occurs when the purpose of the 
reason is directed to an end which is good not in truth but in appearance, or when fictitious or counterfeit means are used to obtain a good or evil end. The thinking out is craftiness, the execution guile (dolus), while fraud or cheating (fraus) is a specific case of guile to do with the execution of craftiness in action. Craftiness, guile and fraud arise from covetousness, as does over-solicitousness for temporal things, excessive solicitude for the future and too much fear about lacking necessary things: all involve a failure to accept God's care and Divine Providence, and draw the individual away from spiritual things (153-167; 2a2ae.55, $3-55,8)$.

\section{Being overwhelmed by affections in FQII - the Phaon episode}

In Canto IV of $F Q$ II we find an episode that operates as an example of what happens if you let the affections overwhelm you. Guyon and his Palmer encounter a young stripling, the hapless Phaon, being dragged along by Furor aided by Occasion. He is trapped in an occasion of furor. Guyon helpfully restrains Furor and Occasion and Phaon tells a tale of betrayal, jealousy and homicidal rage to which the Palmer provides the moral:

\footnotetext{
Most wretched man,

That to affections does the bridle lend;

In their beginnings they are weake and wan,

But soone through suff'rance growe to fearefull end;

Whiles they are weake betimes with them contend;

For when they once to perfect strength do grow,

Strong warres they make, and cruell battry bend

Gainst fort of Reason, it to ouerthrow:

Wrath, gelosy, griefe, loue this Squyre haue laide thus low. (II.iv.34)
}

These affections - wrath, jealousy, grief and love - also run a natural course and "die and decay," the Palmer pronounces (II.iv.35.9). He is describing something like the sequence of the passions in Aquinas from love (or hate) to joy (or sorrow), a process that gains its own momentum but also comes to an end. The sense of such a completed sequence, ending in sorrow, is underlined as Phaon ends his tale, and "thus ended had his sorrowing" (II.iv.33.7). The story serves, it seems, as a cautionary tale of how the passions overwhelm anyone who does not gain rational control of them early in the sequence, and as an example plays a not dissimilar role to Jenefer Robinson's story of the emotional stream that follows the infidelity of the hypothetical husband Joe as a kind of example within an ethical textbook. 
The difference between the sequence described by Robinson and that described by Phaon is instructive. The Palmer's advice might be useful to Robinson's narrative persona, who is overwhelmed by a stream of emotional and cognitive reactions that flow irrationally one from the other and whose judgements cannot be relied on. But these responses are not acted on in a way that causes harm to anyone else. Phaon, on the other hand, commits one first rash and impulsive and one second more calculated act of murder. The story, however, is told in terms of the overwhelming power of the affections. Lied to by Philemon about the fidelity of his betrothed (in a sequence that demonstrates those aspects of false prudence driven by covetousness, cunning, guile and fraud), Phaon is first infected with "gnawing anguish and sharp gelosy" (II.iv.23.1) and then, provided with false evidence, is "assayd" with "horrour and tormenting griefe" (II.iv.28.6-7). To this point he is like Robinson's persona tormented about Joe. But after initially "chawing vengeance," Phaon then kills his betrothed Claribel as soon as she appears: "With wrathfull hand I slew her innocent" (II.iv.29.2-4).

At this point a cognitive reappraisal is required, particularly when the maid Pyrene confesses the innocence of her mistress. Phaon registers his guilt, it seems, and is captured emotionally by a desire for self-destruction, seeking "Vpon my selfe that vengeable despight / To punish" (II.iv.30.3-4). Instead, in an act which no longer seems entirely that of one consumed by passion, he gives poison to Philemon and is intercepted in the story chasing Pryene with a "murderous blade" (II.iv.31.7). Captured and beaten by Furor and Occasion, Phaon pronounces that "death were better, than such agony, / As griefe and fury vnto me did bring" (II.iv.33.5). Concupiscent grief and irascible fury, the passions of the soul, are to blame for all. What are implicitly exempted from blame by this summary are the judgements of the intellect and the operation of the will that must precede the decision to act.

Overwhelmed by passion, Phaon is demonstrating a range of the vices opposed to prudence. He is inconstant in his judgement of his betrothed, he lacks circumspection, failing to sift the true from the false, he lacks the shrewdness that allows the prudent to draw rapidly on memory and judgement, he lacks caution, and so on. Above all, he has not been guided by knowledge of the true, and in particular the knowledge that murder is a sin. The first murder, that of Claribel, follows the pattern of the incontinent person overcome by physical desires who, knowing what is right, follows another path and regrets it later. The more calculated nature of the 
second murder by poison argues for something more like the behaviour of an intemperate person and for the malice of the will.

The disjunction between this story and the advice then offered by Guyon "Squyre, sore haue ye beene diseasd; / But all your hurts may soone through temperance be easd" (II.iv.33.4) - is noted by Darryl Gless, who sees the advice offered by the Palmer (above), that "[a]ll Phaon need have done...is deprive his violent passions of leisure in which to develop" as "bathetic" and based in "silly word games" (Gless 184-5). Gless's conclusion is that the story of Phaon "presents so decisive an instance of the limitations of temperance that it almost produces comedy out of extraordinary violence" (85). While I agree with the general tenor of Gless's case, I suggest a modification of its conclusion. Aristotle is clear that a mean of virtue does not apply to crimes like murder, which are an absolute wrong, and the Christian moral tradition based on the Ten Commandments gives a similarly clear directive. What is at stake in this story is the importance to temperance of the directing power of reason, and prudence becomes false prudence when it fails to draw from true principles. In the case of their interaction with the Phaon story, Guyon and the Palmer generalise from a particular occasion of intemperance and sin to the need for earlier control of the passions. They generalise away from a particular story (that of Phaon) in which it is not just the passions that are at fault but also the judgement of the will - in so generalising they lose sight of the reality that temperance and intemperance are enacted and embedded in specific occasions, the rights and wrongs of which will always be specific to themselves. It is in attempting to apply a textbook generality of the type strongly suggested by the Palmer's oration to specific occasion that the difficulties of ethical behaviour begin, and this is where the disjunction lies.

The clue to the problem is contained in the initial containment of Occasion. Occasion is "the roote of all wrath and despight" (II.iv.10.9) of Furor, the Palmer tells Guyon. Without dealing with Occasion, "It's eath [Furor's] ydle fury to aswage, / And calme the tempest of his passion wood; / The bankes are ouerflowne, when stopped is the flood" (II.iv.10.9). After successfully containing Furor and Occasion, Guyon and the Palmer then fail, in my view, to respond to the particular occasion to furor that the Phaon story contains. That this is a failure is made clear when, immediately after Guyon has advised Phaon that he has been "[v]nlucky" to fall "into mischiefe through intemperaunce" (II.iv.36.1-2), Atin bursts onto the scene announcing the arrival of Pyrochles and seeking Occasion. Despite Guyon's cheerful 
advice-giving to Phaon - "Henceforth take heede of that thou now hast past, / And guyde thy waies with warie gouernaunce, / Least worse betide thee by some later chaunce"(II.iv.36.1-5) - that Occasion has not been successfully contained is shown in the following canto, when she is released again. Part of the consequence of their failure to adequately judge this particular occasion of sin will be Guyon's own fall, and one source of the problem lies in an excess of moral self-confidence.

\section{Canto III - vaunting and failures of fortitude}

The problem of over-confidence in the efficacy of one's own virtue is strongly signalled earlier than the interchange with Phaon and Furor by the sequence of Canto III (which appears otherwise oddly disconnected with the other cantos of $F Q I I)$. Pride, we should not forget, is one of the vices associated with temperance in Aquinas's Summa. After dealing briefly with Guyon's loss of his horse and its discovery (II.iii.3), this canto deals with the two characters (so incongruous that this canto plays almost as a comic interlude), who have discovered and claimed this horse. It has become traditional to see it as unproblematic that Guyon loses his horse early in his legend, that travelling by foot is somehow appropriate to this pedestrian virtue. But it cannot be unproblematic later in the legend when, in Canto VIII, Arthur enters to rescue Guyon and is forced off his horse and on to the ground by Cymochles and left fighting on foot without his sword "[a]gainst two foes of so exceeding might, / The least of which was match for any knight" (II.viii.34.4-5). The fact of being off the horse and at the mercy of the combined forces of concupiscence and irascibility go together in the way familiar from Plato's myth of the charioteer in the Phaedrus - it is the combined strength of concupiscence and irascibility that poses most risk.

Either it does not matter that Guyon loses both horse and weapons at the beginning of his legend, or it is a signal that Guyon's ability to control his irascible and concupiscent urges will become problematic as the legend proceeds. Spenser gives us clues to support both possibilities. At the opening of Canto VI he announces that Guyon is successfully continent. "A harder lesson, to learne Continence / In ioyous pleasure, then in grieuous paine" (II.vi.1.1-2), the narrator explains (following Aristotle) in the opening couplet. Apparently, however, neither are a problem for our hero; we are told as the stanza concludes, "Yet vertue vauntes in both her victories, / And Guyon in them all shewes goodly maysteries." Guyon is morally untouchable, it seems; as the knight of temperance he is quintessentially temperate. Or maybe this is 
not so straightforward. The use of the verb "vaunt" makes an uncomfortable pair with "vertue." The combination "vertue vaunts" has a strong echo of bragging. And this brings us back to the earlier loss of Guyon's horse to the braggard and vaunter of the legend. While Guyon is preoccupied with a tableau representing original sin, a braggart, Braggadochio, goes off with his horse and spear, and Guyon must not only pick up the burden of his own armour but also the armour of Mordant that does him "sore disease." To think it is unproblematic to control your emotions even after you are burdened with original sin is a foolish boast, and in this sense Braggadochio's acquisition of Guyon's horse amounts to a joke at Guyon's expense.

The sequence involving Trompart and Braggadochio allows Spenser to reveal some of the forces that undermine rational self-control by undermining the differing cardinal virtues. Braggadochio is "puffed up with smoke of vanity, / And with selfloued personage deceiu'd" (II.iii.5.3-4). He is a fine representative of what we have seen in Josef Pieper: selfish turning towards the self, such self-turning or self-love that is inevitably in theological terms a form of deception. His companion Trompart is presented at first in terms of the cowardice that opposes courage, throwing himself prostrate before Braggadochio, but then is quietly revealed as duplicitous: "wylie witted, and growne old / In cunning sleights and practick knauery" (II.iii.9.5-6). As already discussed Aquinas sees craftiness as a vice opposed to prudence by way of resemblance. Craftiness occurs when the purpose of reason is directed to an end that is not good in truth but in appearance, and when in order to obtain a certain end whether good or evil a person uses means which are not true, but fictitious and counterfeit. Trompart thus represents one of the forms of falsity that echo prudence by a form of resemblance. Trompart's cowardice makes him a comically ridiculous figure, but the more serious nature of cunning and guile is underlined when the description of the comic pair conjures up the arch-magician and embodiment of evil of Book I, Archimago. As Archimago seeks to use the pair against Guyon, what is again introduced into FQII (as it is at the beginning of the legend) is the role of the false logic of cunning as a weapon to undermine rational self-control.

Braggadochio's foolhardy boasting - that he could beat Guyon and Redcrosse Knight unarmed even when advised otherwise by Archimago - links him with one of the vices opposed to fortitude, that of rashness. Rashness comes, according to Aquinas, when one is not directed by the reason through an impulse of the will or of a passion. Braggadochio's actions are also opposed to an important aspect of prudence, the need to take counsel, and so reveal one of the vices opposed to 
prudence, that of precipitation. The transparency of his boasting is immediately destroyed when Archimago reveals his demonic status, flying off into the north wind, and the pair flee in dread in a wood where "[e]ach trembling leafe, and whistling wind they heare" (II.iii.20.4). Aquinas in the Summa cites Aristotle Ethics, iii.7: "The daring are precipitate and eager to meet danger, yet fail when the danger is present" (2a2ae.127.2).When Belphoebe appears (II.iii.20), rather like a revelation of epic divinity (Venus to Aeneas, for example), there is a clear disjunction of occasion, as if the epic moment finds itself in a pantomime or a Spenserian version of something like Shakespeare's mechanicals' play. Instead of being overwhelmed with awe at Belphoebe's presence, Braggadochio hides himself in the bushes, and so leaves himself at risk of being mistaken for a wounded beast and caught by Belphoebe's spear. Emerging from his state of cowardice like a peacock shaking his feathers, Braggadochio then finds his feelings translated almost instantly into lust. And here Spenser provides an example of the interrelationship of failures of fortitude to failures of temperance, of the kind of "overflow" described by Aquinas.

Braggadochio comically represents the man unfortified against the dangers of death, and this leads to the cowardice of lustful attack (and so also to an act of injustice). As Belphoebe lectures him on the danger of courtly life, "the foolish man, fild with delight ...[g]an burne in filthy lust, and leaping light, / Thought in his bastard armes her to embrace" (II.iii.42.2-6). As Belphoebe leaves, and so the pair lose the benefit of her counsel, the comic sequence returns to a description of their cowardice and the irritation of the horse which both mount and which restlessly "to be eased of that base burden still did erne" (II.iii.46.9). If the horse represents passions that should be controlled by reason, the problem Spenser now presents comically is that of cowardice and lust attempting to control the passions. The underlying messages of the sequence are more serious. Revelation of divine truth is likely to be mistaken by those failing in the cardinal virtues. Those failing in the cardinal virtues are also vulnerable to the manipulation of demonic power - and in one sense this amounts to the same thing.

\section{Emotional streams - Canto IV to Canto VIII}

At the opening of Canto IV we are told the rightful owner of the steed, Guyon, "well could menage and subdew his pride" (II.iv.2.2). But it seems this is only because the Palmer will not suffer Guyon's "wandring feete to slide.” The Palmer is constantly intervening to change Guyon's direction. 
But when strong passion or weake fleshlinesse,

Would from the right way seeke to draw him wide,

He would through temperaunce and stedfastnesse,

Teach him the weak to strengthen, and the strong suppresse. (II.iv.2.6-9)

It is as if Guyon is being controlled by the Palmer as charioteer, bridling Guyon's potential recklessness or waywardness as it occurs. That such control is insufficient in made apparent as Guyon becomes immersed in a series of encounters that will leave him rendered entirely powerless and at the mercy of the combined forces of Cymochles and Pyrochles. There are two ways of looking at the conclusion of this sequence. If Guyon is seen in terms of the apparent confidence of the description of his continence that opens Canto VI, and the description of the self-control exerted by the Palmer on his behalf (cited above), then his collapse can be seen as the extenuation of virtue without faith, the natural end of natural virtue without grace. Guyon has been an exemplary knight of temperance, always responding correctly and with appropriate restraint and self-discipline, but it is in the nature of temperance to be limited and need the spiritual support provided by the angel and Arthur.

I would like to suggest that, contrary to this more positive view of Guyon and working against the depiction of Guyon's moral confidence at the narrative level, Guyon's entanglements with Furor, Occasion, Atin, Pyrochles, Phaedria, Cymochles and Mammon are similar to the experience of a turbulent emotional stream, such as that described by Jenefer Robinson. Guyon's interactions with the allegorical forces that attack him follow the pattern of the affective and cognitive appraisals and reappraisals of Robinson's description. Guyon and his Palmer often seem to be winning in the encounters of this stage of their journey, first subduing Furor and Occasion, and then later releasing them and abandoning Pyrochles, Furor and Occasion to their fates. But despite their apparent victories in the battles, the ultimate direction of the war follows a downward progression, literally downwards in the case of Guyon's descent into the Cave of Mammon. At first the Palmer is able to intervene to protect Guyon from mistakes, or (in representing cognitive appraisal) explain to him the emotional scenario with which he has just been involved. But the model of self-control which requires the Palmer to step in to retrieve Guyon's recklessness or waywardness unravels as Guyon goes off in Phaedria's boat without the Palmer. What is particularly helpful in Robinson's view of the person immersed in an emotional stream is their loss of judgement and inability to correctly categorise their responses or even to be properly aware of them. This view of the emotional 
sequence should make us more cautious about accepting at face value the Palmer's judgements in the middle of the emotional stream. As Guyon encounters first Pyrochles and then Cymochles, we see the wild swinging between the manic and lethargic that Robinson portrays as characteristic of such a stream. As we have just seen, for Aquinas lack of fortitude leads naturally to lack of temperance, and with this lack of temperance a natural regression to the passivity of the concupiscent state of the soul.

Why does the apparently temperate Guyon become immersed in an increasingly unravelling emotional sequence at this point in the narrative? The answer lies in the initial infidelity of the Book, Mordant's straying with Acrasia. Guyon responds to the tableau of Mordant and Amavia with wild grief and the desire for revenge. To put this another way, he is grief-stricken at his discovery of the nature of original sin and the weakness of human fleshliness. On the other hand, he is immensely confident about his own moral worthiness and his ability to combat any occasion of human weakness he encounters. Somehow he has not put the two pieces of the picture together, that innate human weakness in general must apply specifically to him: he has not gained the deep self-knowledge required by the Book. In these early sequences, Guyon's obliviousness and hence overconfidence is presented in an exaggerated form in the episode of the comic vaunters Braggadochio and Trompart. Guyon is inevitably open to emotional attack (which is another way of saying to the weakness of will that Acrasia represents).

That Guyon does not have the habit of virtue associated with prudence is made clear in his enactment of varied forms of imprudence. Of these, the one that most strongly characterises Guyon is rashness. To avoid precipitation, the soul needs to act in an orderly manner by degrees, not by impulse, and Aquinas suggests one may be rushed into action by an impulse of the will or of a passion or from contempt of the directing rule (and in this case this is a result of pride). Guyon, by contrast, acts impulsively in rushing in with "impetuous forse" (II.iv.6.3) against Furor, so that he "ouerthrew him selfe vnwares, and lower lay" (II.iv.8.9). This overthrow leads to the physical symptoms described by Aristotle as accompanying the irascible state of rage. Guyon responds to both the physical attacks of Furor, who now has him in his power, and the verbal abuse of Occasion, and "emboyling in his haughtie hart" (II.iv.9.6), breaks free and reaches for his sword. Drawn into the episode by the concupiscent emotion of sorrow, Guyon finds his feelings have quickly escalated to 
full-blown rage and vengeful intent. He is about to behave, in other words, as we will find Phaon has behaved. It is only at this point that the Palmer intervenes.

Guyon's tendency to rush in first and ask questions later, the imprudence of rashness, is seen first in the encounter with Redcrosse Knight. Here memory intervenes, and Guyon recognises the meaning of Redcrosse's shield just before attacking him. Guyon shows shrewdness, the ability to quickly sum up a present situation based on the prior knowledge of memory and good judgement. The case of his encounter with Furor shows how quickly such underlying principles can be lost sight of once one is entangled by one's passions. However, all is not lost at this point. Guyon's self is overthrown but he does at least respond to his Palmer's reasoning, showing that important attribute of prudence, docility in accepting guidance.

\section{Negligence, concupiscent sloth and false prudence}

What Guyon and his Palmer then display, in dealing with the general rather than the specific in the particular occasion of Phaon's crime, is a kind of avoidance strategy. As the sequence moves into Canto V, avoidance becomes the theme (or in Aquinas's terms, that defect of prudence which is negligence, and in Robinson's emotional stream the lethargy that follows the manic response). Attacked by Pyrochles, and after "[t]empring the passion with aduizement slow" (II.v.13.2), he lets Pyrochles escape and pronounces the lesson which now clearly applies to himself (as one foolish enough to release irascibility): "Vaine others ouerthrowes, who selfe doth ouerthrow" (II.v.15.9). As Occasion and Furor when released stir up trouble with Pyrochles, and Guyon is appealed to, the Palmer restrains him and pronounces: "He that his sorow sought through wilfulnesse, / And his foe fettred would release agayne, / Deserues to taste his follies fruit, repented payne" (II.v.24.7-9). The irony of this pronouncement to a Guyon who has just released Pyrochles and allowed Pyrochles to release Furor and Occasion must not be underestimated.

The combined foolishness of the Guyon who stands for temperance and his Palmer makes them at this point little different from Trompart and Braggadochio, and they show all of the comic pair's vanity and pride as the Palmer withdraws Guyon from the battle as if its elements no longer concern them: "So him away he drew / From needlesse trouble of renewing fight / Already fought" (II.v.25.1-3). There are strong overtones of hand washing in this withdrawal, and that they amount to a failure on the part of the advice-giving Palmer is shown as Guyon is soon separated from him, stepping into Phaedria's boat and entering the domain of 
concupiscence with its Idle Lake. His absence then corresponds directly to negligence, the inability to choose the right (in this case withdrawing instead of engaging).

As Guyon struggles alone with both Phaedria and Cymochles, he is not completely overcome. But his struggle is more like the struggle of the passions within the sensitive soul than a struggle of reason and the will with concupiscence, and such a struggle is appropriate for one who has lost touch with his governing reason. Guyon wins the inner struggle at the level of the sensitive soul of irascibility against concupiscence, but his escape from Phaedria's wandering island only (or inevitably, as it is a species of irascibility that has enabled Guyon to stand up to the concupiscence of Cymochles and Phaedria) serves to reintroduce a still internally burning Pyrochles to the narrative at the end of Canto VI. That only Archimago (so strongly associated with the demonic challenge to faith in Book I of The Faerie Queene) can restore Pyrochles at this point is a signal that a problem with ultimate ends underlies the sequence. And so the narrative moves naturally into the territory of prudence of the flesh.

\section{The Cave of Mammon and prudence of the flesh}

That the Palmer does not accompany Guyon into the Cave of Mammon is consistent with his earlier act of drawing Guyon away "from needlesse trouble of renewing fight / Already fought." The sequence of the Cave of Mammon ends with the ultimate act of negligence, the hand-washing of Pilate who "deliuered vp the Lord of life to dye." Pilate appeared to have behaved rationally, even to have behaved prudently. And this is the problem with prudence of the flesh: its very resemblance to prudence. The guile of Mammon does not lead Guyon to accept the material goods of the cave. But it does lead him to neglect the things of the spirit - it is a long detour of negligence that ultimately leaves him both spiritually and physically defenceless.

Guyon's debate with Mammon at the mouth of the cave (II.vii.7ff) also demonstrates the problematic syllogistic behaviour of the incontinent (the case in Aquinas reported by Pasnau (246-7)). The incontinent person knows the primary premise, "no sin should be done," but instead of following through with the minor premise "this is a sin" and therefore "this should not be done," he or she accepts instead a form of the major premise - "all pleasure should be pursued," and the minor premise and conclusion, "this is a pleasure" therefore "this should be pursued". Guyon explains to Mammon why worldly goods should not be sought as a 
goal: "Indeede (quoth he) through fowle intemperaunce, / Frayle men are oft captiu'd to couertise" (II.vii.15.1-2). But Guyon is overcome by his curiosity, a form of covertousness and one of the vices associated with intemperance by Aquinas and Augustine. In this case, Guyon's search for knowledge of the sources of the world's goods becomes an irresistible pleasure to him, one that leads him to abandon the general case he has himself already put to Mammon. The bargain the guileful Mammon strikes with him is that Guyon may try his strength in refusing the temptations of the cave, but that if he is successful in resisting its goods he will no longer describe them as a source of sinfulness - "But thing refused, doe not afterwards accuse" (II.vii.18.9). Morally, in terms of ultimate spiritual ends, Guyon cannot win.

If one aspect of irascibility is resistance, Guyon is at this point strongly in the grip of a passion, that of resistance for its own sake, the demonstration of fortitude for false ends. His disdain for the cave's temptations leads him naturally to encounter the allegorical figure Disdayne; his berating of Tantalus for his intemperance (as though he was himself exempt from the risks of intemperance) leads him naturally to the hand-washing of Pilate. Coming out of the cave and collapsing, Guyon is inevitably attacked again both by Pyrochles and by Cymochles. Guyon needs not only to be restored to a controlling reason, but more importantly to a reason properly aligned to faith. And it is only this restitution of prudence to ultimate ends that allows Guyon to emerge from this long emotional stream as from a dream.

\section{Rational self-control in Hamlet: "But break, my heart, for I must hold my tongue"}

As the court leave Hamlet alone on the stage in Act I scene 2, he allows us to experience through his soliloquy an internal emotional stream. In comparison with the jealously homicidal Phaon, Hamlet is at this point of the play remarkably restrained, and the need for restraint marks the conclusion of the speech: "But break, my heart, for I must hold my tongue" (1.2.159). Nevertheless he goes through a sequence of shifting emotions and thoughts, leavened with exclamatory phrases ("O God, God"; "Fie on't, ah fie,”; “That it should come to this!”; “Must I remember?”) that demonstrate the passion churning away beneath. He begins with the absolute despair of suicidal wishes, moves to despairing disgust at the world, shifts to the source of the despair, his mother's marriage, and, in checking the accuracy of his 
recollection of the time that has passed, moves to memory and then wishes he had not remembered, abuses all women, returns to the main theme of time passing and so on. In the sequence, sorrow and despair creep slowly into anger and return to the sorrow of "but break my heart." It is a shorter sequence than that described by Robinson, but of a similar type, and it both reveals the underlying passions that will govern later action - Hamlet's disgust at the way concupiscence has overridden reason in the case of his mother - and something of his need to both express and whip up his own passions.

The next two scenes introduce the play's preoccupations with concupiscence and irascibility, the first through the "shot and danger of desire" speech (1.3.35) of Laertes to Ophelia; the second through the ghost's injunction to revenge. The play's preoccupations with the concupiscence of lust and irascibility of revenge alternate, combine and separate again throughout the rest of the play, and so do the behaviours we associate with Cymochles and Pyrochles in FQII, the lethargy, impulsiveness and penchant for vicarious pleasure of the first, and the burning up with ungovernable rage of the second. Laertes' advice to Ophelia has a prurient edge; Hamlet responds to the appearance of the ghost with a fearless irascibility that quickly develops into a waxing "desperate with imagination" (1.5.87). He is, in fact, rash, and the sequence in which Marcellus and Horatio attempt to prevent him from following the ghost amounts to injunctions against the vices opposed to prudence, against precipitation and thoughtlessness, lack of caution and circumspection.

Horatio's description of the place allies it with the destructive churning of the passions: "The very place puts toys of desperation, / Without more motive, into every brain / That looks so many fathoms to the sea / And hears it roar beneath" (1.4.7578). Hamlet also fails in that attribute of prudence that accepts the importance of advice, docility, instead responding to his companions with irascibility: "Hold off your hands" (1.4.80). He will not "be ruled," even to the point of threatening violence to his friends, and is filled with a haste to execute revenge worthy of Pyrochles, and which the ghost contrasts with the kind of lethargy that belongs to Cymochles, that of Lethe wharf (1.5.33). And by the end of the sequence, having sworn his friends to secrecy, he has also separated himself from their potential to advise him.

In Act Two we move into a world of cunning, guile and fraud - acting a part becomes the modus operandi of almost everyone. The false prudence of Claudius, the vice that operates as we have seen by resembling prudence, has either slowly 
infected the whole court, or emerged naturally in its environment. Polonius begins this sequence by asking Reynaldo to play-act the ingenuous acquaintance of Laertes, assuming Laertes' concupiscence will inevitably reveal itself. Hamlet play-acts madness, but in detecting the duplicitous play-acting of friendship of Rosencrantz and Guildenstern reveals the extent of his own prudence. Aquinas gives the example of someone initially responding to expressions of love and then detecting signs of flattery as an example of that aspect of prudence which is circumspection (Aquinas 79; 2a2ae. 49,8). Shakespeare at this point seems to be employing a textbook case. As if conjured up by the discovery of play-acting in his supposed friends, the imminent arrival of the players is announced and quickly followed by the playing out of the extremes of irascibility and sorrow at the death of Priam. Pyrrhus is Pyrochles (one of the alternative spellings Spenser uses is Pyrrhocles) - "roasted in wrath and fire" (2.2.419).

The Senecan bombast of the player's version of Aeneas's speech to Dido delivers a hyperbolic version of the feelings Hamlet has already expressed, sorrow at the death of a father and anger at the betrayal of his mother and uncle manifesting itself as a desire for revenge. But by this stage of the play the passionate surge of Hamlet's own rage has died down, in the natural way described in the speech of the Palmer - "wrath, gealosy, griefe, loue die and decay." He has settled into a more melancholy kind of sorrowing, a version of the indolent Cymochles' concupiscent lethargy, or that feared by the ghost as belonging to Lethe wharf. The demonstration of raw furor and naked grief in the player's speech makes him aware how inadequate his own passion is as a catalyst to violent action. And so he begins the second soliloquy, looking to reignite the passion that leads to the necessary impulse to violence. The soliloquy builds from an initial disgust at his own indolence ("O what a rogue and peasant slave am I!" (2.2.502)), to amazement at the artificial passion of the player who could "[b]ut in a fiction, in a dream of passion," show the physical manifestation of passion, and from this to the recognition that he has a stronger cause for such passion ("What would he do, / Had he the motive and cue for passion / That I have? He would drown the stage with tears", and so on). But the speech then collapses from these beginnings of an artificially contrived passion as Hamlet describes his lethargy and inaction and views himself, Lethe wharf-like, as "[a] dull and muddy-mettled rascal" (2.2.519). Hamlet then (like Cymochles roused from slumber, suddenly leaping up from his lethargy and looking for a fight) starts shadow-boxing with an unseen adversary: "Am I a coward? / Who calls me villain 
...Who does me this?" The issue now becomes courage or fortitude - that all that stands in the way of executing revenge is the lack of the irascible backbone of Plato's spirited horse. As he moves into insulting the king, his passion returns; he has successfully wound himself back into irascibility: "Bloody, bawdy villain! / Remorseless, treacherous, lecherous, kindless villain!” And from hence he goes into the temporary grip of furor: "Oh, vengeance!" (2.2.532-34).

But the artificial whipping-up of emotion cannot be sustained; a variant of cognitive reappraisal quickly intervenes, and Hamlet sees himself as an actor whipping himself up emotionally, or worse than an actor. What comes to the surface as more intellectual processes take control is the effectiveness of the acting of emotion as a means of stirring up emotion, and Hamlet moves to devise his own strategy of cunning and guile, the "Mousetrap" play. And from this contriving comes the dim consciousness that contriving itself is a suspect business, that the undermining effects of "weakness and melancholy" can destroy the proper operations of rational decision-making. Hamlet, in other words, is starting to exercise the caution and circumspection recommended to him earlier by Horatio and Marcellus. The logic of the moral ambiguity of using contriving to capture the contriving of another to avoid being trapped by the contriving of a third agent (the ghost) eludes him; but even so, what is winning at this point is not the lethargy of concupiscent passion but the caution of rational choice. The play's internal moral tension - built on the problem of how to resist the immoral behaviour of others without oneself behaving immorally - is further tightened.

\section{The puzzled will of Act Three}

In Act Three Hamlet's caution is again blown apart by passion, and that selfless preservation of the self which Josef Pieper associates with temperance is irrevocably undermined. As Claudius begins the act acknowledging the hideousness of deception we start to see the open face of false prudence in Hamlet's adversary. Setting up Ophelia as a stalking horse so they can spy on Hamlet, Polonius notes that "' $[\mathrm{t}]$ is too much proved, that with devotion's visage, / And pious action, we do sugar o'er / The devil himself" (3.1.47-9). For Claudius, this is a lash to his conscience that will have its ultimate effect in his attempt to repent in the centre of the act: it is to this scene that the act in some ways must be seen as building. Using imagery of concupiscence that will next be employed by Hamlet against Ophelia, Claudius confesses: "The harlot's check, beautied with plastering art, / Is not more ugly to the thing that helps 
it / Than is my deed to my most painted word. / O heavy burden!" (3.1.51-4). In this brief aside to the audience, Claudius paints himself as an Archimago figure - he is the devil Polonius has just described, the devil Hamlet is afraid is hidden in the shape of the ghost.

Claudius's inability to retrieve his sin, the deep moral lethargy of the intemperate whose passion rules action in such an entrenched way that it makes them unable to access the moral action of the will, is placed in apposition to the suicidal desire to avoid all moral choice of the Hamlet who enters next. Hamlet wants to entirely renounce the act of the will, "to die, to sleep," and the lethargy he describes is so strong that it cannot access the fortitude of either resistance to "the slings and arrows of outrageous fortune" (3.1.60-63), or the fortitude of a stoic suicide. Concupiscent passivity remains unopposed by the irascible. But where in the soliloquy of Act Two rational reflection undermines the build-up of irascibility, rational thought in this soliloquy intercepts the drift of the concupiscent inactivity. What intervenes is in fact foresight - the recognition of consequences that are not accounted for by allowing the passivity of the concupiscent passion to take control, the "dread of something after death" that "puzzles the will" (3.1.80).

And behind this, and in the same way we have just seen for Claudius, lies an acknowledgement of a higher right and wrong that conscience has access to, the natural basis of truly prudent action. But Hamlet's judgement is still astray as he sees in the action of the intellect a source of lack of fortitude ("thus conscience does make cowards of us all" (3.1.83); he is looking implicitly for irascibility to overcome such rational insight and control. What he wants is to act against the urges of his conscience, for the irascible horse to gain the upper hand over the reason of the charioteer, seeing the "puzzled will" as the source of his inactivity. Both Claudius and Hamlet, in other words, begin the Act with statements that explicitly demonstrate where the moral good in the play should lie, and the problem for both then becomes the inability of the will to act in accordance with such conscience, although the will in each case is undermined differently, in accordance with the difference between the incontinent and intemperate individual. Hamlet's conscience (in the analogy with that of the incontinent person) has more potential to affect his behaviour than that of Claudius, but Hamlet is also more vulnerable to rashness, to impulsive choices driven by the passions, and this is in fact the path his downfall takes in the Act.

In the exchange with Ophelia and his denunciation of her as the root of all concupiscence, Hamlet's irascibility rises to a natural climax, with its final threat 
against the king (and more latently against the queen): "Those that are married already, all but one shall live" (3.1.141-2). It is not irrational for Claudius to see danger to himself in what he has overheard, nor to understand the potential for the underlying irascibility to tip into actual madness. In the preparation of the players and his praise of Horatio, Hamlet appears as rationally in control as Claudius; in his excited bawdy taunting of Ophelia before the opening of the play it is hard to judge which of passion and calculation is in control. And this leads into the "Mousetrap" play's themes of inconstancy and its failures of memory, of the unreliability of judgements driven by passion. "What to ourselves in passion we propose," says the Player King, "The passion ending, doth the purpose lose" (3.2.175-6). The Player King's speech is very similar in tone and meaning to that of Spenser's Palmer ("wrath, gealosy, griefe, loue die and decay,") about the ways the passions naturally destroy themselves: "The violence of either grief or joy / Their own enactures with themselves destroy" (3.2.176-77).

Hamlet's plot of cunning and guile is successful - Claudius is goaded into an exhibition of passion, he is "marvellous distempered...with choler" (3.2.273-5). And Hamlet is cautiously aware of his own potential for such distemper; he could easily, like Pyrrhus or Pyrochles, "drink hot blood / And do such bitter business as the day / Would quake to look on" (3.2.351-3). He injuncts himself to "speak daggers" to the Queen, "but use none" (3.2.357). And passion does not overcome him as he comes across the king at prayers, although the duplicity of false prudence seems to be at work in his rationalisation; but it does so hideously when he hears the noise behind the arras, enacting the response of rashness. Like the homicidal Phaon, Hamlet shows in this act aspects of uncontrolled passion, but also like Phaon, behind the rashness lies all the preparation of the previous "thinking on the act." Its impulsiveness cannot disguise an element of calculation in the choice of the will to act, and the absence of that shrewdness of true prudence that would have rapidly calculated the true nature of the potential threat. And, as with the case of Phaon, any attempt to reach for selfcontrol from this point cannot undo the nature of the crime that has been committed. And while Hamlet goes on to use the defence of temperance with Gertrude (as previously discussed), it is irascible passion that now drives his verbal attacks on her, and that tips him into the apparent or actual madness of the appearance of the ghost. He has, like Phaon or Pyrrhus, been captured by furor in an occasion of $\sin$ - that Furor that in Spenser is "a mad man or who feigned mad to be," and where the difference between the true and the feigned has become in some sense immaterial. 
From the point of the slaying of Polonius, the distinction between madness and feigning madness, the appearance of loss of self-control and actual loss of selfcontrol, becomes harder to draw in the play.

In Act IV Laertes takes up the irascibility of revenge, Ophelia acts out the madness of complete loss of rational self-control and the concupiscence of a suicide that takes the form of an absolute weakness of will - to the extent that the water will come to her and drown her, as the grave digger describes it (Laertes and Ophelia become the play's Pyrochles and Cymochles if you will), while Claudius continues to act out the path of false prudence from which he has been unable to retrieve himself through true confession. Failures of the reason directing rational self-control and actions of the passions undermining rational self-control work together in an inexorable manner to the play's tragic conclusions. 


\section{Chapter Eight: The journey of the soul: temperance, assimilation to God and justice}

\section{FQII, Hamlet, and the violent end of the Aeneid}

Book II is the book of The Faerie Queene that refers most directly to the epic. It does this in a range of ways, and one is by replicating in a more minor tone the shocking, decisive and merciless slaying of Turnus that abruptly ends the Aeneid. It is the sudden, decisive and abrupt destruction of the Bower of Bliss that surprises the reader. In Hamlet the shock and surprise are experienced dramatically - Hamlet is poisoned, Laertes poisoned, the queen poisoned, and Hamlet now acts decisively against the king, implementing the revenge requested by the ghost at the play's inception. He acts mercilessly and dies.

R. D. Williams describes the ending of the Aeneid in the following way. Aeneas must straddle the heroic Homeric world and the Roman world that he must inaugurate; he must become "a hero for an age no longer heroic" (Williams xxii). (This is the very problem that, as we have seen, makes sophrosyne an important virtue for the Greek polis). While the bravery and resolution of an Achilles might fit the new Rome, others of the heroic qualities such as "impetuosity, proud selfconfidence, concern for self" (Williams xxii) will not. The new hero must be concerned more about the group than the individual, and what is required along with the virtue of pietas, responsibility towards gods and men. Duty towards others may involve (as Williams puts it) "subjugation of individual passions (like the desire for glorious death at Troy, or the love of Dido) to the demands of duty" (xxiii). This is the key lesson Aeneas is taught in a meandering journey that, with the central descent into the underworld and its vision of the imperial future to come, becomes a journey of self-knowledge. In the final books of the Aeneid, a dichotomy is established between Turnus, who represents the old heroic type of warrior and so is associated with a range of intemperate behaviour, and Aeneas, who fights reluctantly and only from duty. But still, on three occasions on the battlefield "Aeneas becomes exactly like Turnus" (Williams xxiv): after the death of Pallas; after he has been wounded; and finally, at the end of the poem. Williams argues:

Here, when Turnus begs for mercy, we expect Aeneas to grant it; but he sees the belt of Pallas on Turnus' shoulder and in a fit of fury and a lust for vengeance he kills him. If we remember the circumstances of the death of Pallas (10.441f), we easily understand why Aeneas feels himself justified - 
but the fact remains that at the last moment Aeneas is no different from the old heroic type he is supposed to be superseding. Nothing could have been easier for Virgil than to avoid this dilemma - instead of being wounded in battle Turnus could have been killed - but he wanted his readers to be involved in the dilemma. How righteous is righteous anger? Are we glad that Aeneas yields to it? (xxiv)

Both Spenser in FQII and Shakespeare in Hamlet pose equivalent questions at the end of their works. How righteous is the righteous anger of Guyon as he destroys the Bower of Bliss? Is he right to destroy it? Similarly, how righteous is the righteous anger of Hamlet when he first stabs Claudius and then thrusts the poison down Claudius's throat? Does Claudius' manifest guilt and intemperance justify Hamlet's act of impromptu justice? All three works, the Aeneid, FQII and Hamlet, end with a victory over intemperance executed with intemperance. Given the degree of direct reference to the Aeneid in both the other works, it is not implausible that both Spenser and Shakespeare are consciously mirroring the famously shocking ending of the Virgilian epic. If this premise is correct, all the problems of Virgil's ending also accrete to the works that are our subject, and in Spenser these problems are attached directly to an exploration of the virtue of temperance. What is highlighted at the end of each work is the relationship of temperance to justice.

Part of what is shocking about Aeneas' merciless slaying of Turnus is its disruption of the apparent progress of Virgil's epic hero to the stature of a leader not easily moved by emotional vicissitudes. The meandering journey around the Mediterranean has tested and strengthened the hero's personal self-control. The knowledge of the destiny that awaits him, revealed in the underworld, has supported his quest for self-knowledge. In terms of a forward progression to the virtue required of the founder of Rome, Aeneas' equanimity, his temperance, should not be so easily undermined by furor. Unless we subscribe to some form of argument that justice sometimes requires that temperance is set aside, Aeneas' behaviour is regressive, a return to a mode of behaviour the poem has carefully established as undesirable. The poem's sense of an inexorable, if sometimes meandering, forward movement to virtue and self-knowledge, is disrupted by the ending.

In the book of The Faerie Queene that draws most strongly on the epic tradition Spenser also establishes a sense of an inexorable, if somewhat meandering, forward movement towards an ideal of temperance and self-knowledge only to undercut, I will argue, any sense of ultimate perfection on the part of his protagonist in the final canto, much as Virgil does in the Aeneid. This and the following chapter will explore the dimensions of temperance as a metaphysical virtue. It will trace the 
relationship of temperance as an ideal to be achieved spiritually and to be used in turn to reach the spiritual perfection seen in the metaphysical thought of Plato and in neo-Platonism. It will outline a precursor of Spenser's treatment of temperance as an epic journey of the soul, the Italian humanist exegesis of the Aeneid by Landino. It will examine the influence of neo-Platonism on the role of temperance and the acquisition of self-knowledge in early patristic writing, in particular Clement of Alexandria's treatment of the exemplary role of Christ as the Word and Augustine's anguished attempts to be reunited, through the Word, with God as the One in the Confessions. It will examine the importance of the Pauline and Protestant emphasis on the Word for $F Q I I$.

While both Spenser and (I will argue in the next chapter less overtly) Shakespeare in Hamlet raise expectations of a successful forward journey towards an ideal of temperance, they are also preoccupied with the risks accompanying such an enterprise. These risks become most apparent when an inner state of temperance is placed in tension with the intention to pursue justice - the desire to reform, judge and punish the intemperate. As it was for Virgil this is a worrying tension for an era of reformation and counter-reformation. It cannot be adequately understood without some initial sense of the dimensions of temperance as a spiritual and metaphysical ideal in both classical and Christian thought. To this we will now turn.

\section{Platonic assimilation to God and injustice}

In previous chapters we have looked at the virtue of temperance in terms of a tension between the classical and Christian; in terms of political and social moderation; and in terms of rational self-control. At the opening of Chapter Three I alluded to the need to eventually return to a more metaphysical approach to temperance, and to the self-knowledge that, for Heraclitus, involved a searching examination of the soul to discover its relationship with the universal law common to man and the cosmos. Sophronein (to become temperate), as previously mentioned, is in this sense for Heraclitus the greatest arête: "It is another name for the faculty by which man may attain that wisdom whose object is the universal logos. Through this process man comes to know the law that governs his own soul and the rest of the universe" (North 27). This metaphysical approach to temperance finds its way into the Early Modern period through a Platonic stream in the braided conceptual river of temperance. We see its importance in the struggle of the soul to ascend to God in the myth of the charioteer in Plato's Phaedrus. On the one hand there is the risk to the ascent to God 
if the concupiscent aspect of the soul drags away the spirited aspect. Conversely, concupiscence and irascibility combine when reason controls the spirited horse and the spirited horse controls the concupiscent horse, and all work together to speed the ascent. Temperance plays a pivotal role in the metaphysical quest for spiritual knowledge of the divine.

In Plato's Laws, sophrosyne is directly associated with the process of assimilation to God. To be temperate is to be like God, because God himself is sophron.

\begin{abstract}
What conduct is dear to God and follows after Him?...God would be for us the measure of all things... and he who would be dear to Him must become like Him, so far as possible. According to the present reasoning, the sophron among us is dear to God, for he is like Him, and the man who is not sophron is not like Him, but different and unjust. (Plato Laws 716C-D; qtd North 194)
\end{abstract}

It is this Platonic relationship between temperance and justice that we must consider if we are to see the ending of Hamlet in terms of the virtue of temperance. In these Platonic terms, if to become like God is to become temperate, because God is sophron, then to become temperate like God, is also to become just. The converse is also true.

For Plato, temperance is also strongly associated with the self-knowledge of the philosopher's preparation for death, the mele thanatou, most clearly in the Phaedo. In this dialogue, the soul is weighed down by its contact with the body, and so to achieve purity the appetites must be suppressed and sophrosyne practised in life. It is such temperance that is demonstrated by Socrates as he awaits his own death by poisoning. Temperance is also associated by Plato with divine love as a path to the divine (North 165-6). In the Symposium, the metaphysical temperance of good order within the soul, a sophron krasis, is associated with the harmony of the physical elements of the universe when the heavenly Eros prevails. Thus in Plato the human prepares for death by a temperate acceptance of the limitations of life; he or she reaches for divine harmony as love accomplishes a state of temperate harmony within the soul. Inner temperance and inner justice become almost synonymous (North 166-9).

\title{
Temperance as a cathartic virtue in Plotinus
}

Neo-Platonism took these aspects of Platonism in a more mystical direction, with Plotinus in particular drawing on the idea in the Phaedo that the virtues are purifications (North 237). In the Enneads, Plotinus elaborates the process of ascent to 
God into three stages. The goal of philosophy becomes unification with the divine as The One, the return of the soul to its origins. The stages are the civic, the cathartic and the paradigmatic. All the cardinal virtues are involved at each stage of the process of purification. The civic virtues contain and moderate the appetites and remove passions and false opinions; the second, cathartic, stage purifies the soul from the taint of matter, and so goes beyond introducing measure in the soul (in the style of Peripatetic ethics) to becoming detached from the sufferings of the body (in the style of Stoic apatheia). This stage can be identified with the assimilation to God. The final stage involves imitation of the Divine Mind, and this imitation produces exemplary (paradigmatic) virtues. All parts of the soul are now united and one part does not need to control the other. "Sophrosyne now takes the form of a turning (or conversion) towards the Divine Mind...for in the Divine Mind itself sophrosyne consists in a turning towards itself." (North 239).

\section{Renaissance neo-Platonism and Landino's Aeneid as a journey of the soul}

Plotinus and Virgil are brought together in Italian humanism. In the Disputationes Camaldulenses (1474), the exegesis of the Aeneid by the Italian writer Cristoforo Landino, the first six books of Virgil's epic journey become a neo-Platonic journey of the soul. What is most helpful for our purposes in this particular exegesis (one of many exegetical treatments of the Aeneid from the first century onwards) is Landino's exploration of the obstacles to the acquisition of temperance as a cathartic virtue, a virtue that will purify the soul and bring it to knowledge of the Divine Mind. In Landino's elaborate allegory, the soul journeys to Italy or true wisdom, and the story, up to the arrival in the Elysium fields of Book Six of the Aeneid, is presented in terms of the two stages of the civic and purgative (or cathartic) virtues. The first stage of Landino's journey of the soul involves the civic virtues, and is completed when the Trojans arrive in Italy; the second, in the journey through the underworld, involves the purgative virtues. As well as a journey towards a summum bonum of true wisdom, Aeneas's progress is implicitly charted in terms of his development of the virtue of temperance.

In Landino's allegory (and from this point I will cite Stahel's translation), Troy is associated with pleasure, and that Aeneas's father Anchises must be carried from it shows that the body prefers corporeal to incorporeal things (69). Aeneas's dual parentage represents the immortal part of the soul (Venus) and the mortal part (Anchises) which leads to the struggle of the spirit against the flesh (and Landino 
makes this explicitly Pauline by adding "as we Christians say" [69-70]). As is explained when Anchises' death is first mentioned, "we will never arrive at true contemplation until sensuality - to use the Christian word - has not only died in us but been completely buried" (110). The Trojans journey first to Thrace, on a sea which represents the appetites, (72) because "when we depart from pleasure but have not truly contracted the habit of virtue we easily fall from sensory pleasure into the desire to possess" (78). The rest of the journey is similarly explained, as representing not only the flight from vice but also the erasure of lust and avarice from the memory.

As well as neo-Platonism, Landino also draws on the Aristotelian distinctions between temperance and continence, describing some of Aeneas' progress in terms of regression. Why does Aeneas weep when he leaves Troy? "Because we are not yet temperate but only continent, we do what we have to do; but, accustomed for a long time to pleasure, we are satisfied with its illicit delights, and are not torn away from it except with reluctance" (74-5). So Aeneas moves between continence and incontinence and back again, through mistakes such as those of Anchises' misreading of the Oracle at Delos. The message of the Oracle to find the ancient mother amounts, Landino claims, to “nosce teipsum, Know Thyself” (83), the ancient Greek concept of temperance. Dido, who initially represents temperance (148), with her kingdom of Carthage a state of Platonic harmony (146), then demonstrates a pattern of complete regression. As she is tempted by Aeneas she lapses first into continence, needing to repress her desire; then into incontinence, as she falls under the influence of her sister's counsel (76); and finally into intemperance (148). Aeneas also falls from continence to incontinence in his relationship with Dido. In leaving Dido and Carthage he demonstrates the victory of continence over incontinence (174-5). The struggles to this point are those of the civic virtues.

When the Trojans arrive in Italy, the battle becomes that of the purgative virtues, equated by Landino with the Pauline battle of the spirit against the flesh (193). And Landino sees this as a stage of great danger. While on the one hand we may be "led by heroic strength to transcend what is of man," on the other we may "degenerate into a beastly existence because of madness and black bile" (193). The journey through the underworld is identified as one of self-knowledge (198) in the spirit of Dante's journey through hell. Vice must be understood before the soul can be freed of it, and the Sibyl's leading of Aeneas into the underworld represents the mind descending into sensuality, but with learning leading the way (205). It is hard 
to return from this journey - it requires the twin platonic wings of religion and justice (207-8).

Nevertheless, Landino is essentially optimistic about the soul's ability to free itself. Wicked people become the slaves of sin through habit, and in the beginning the actions of these people are voluntary. But Landino also sees human souls as born platonically of a heavenly seed, "and unless they hand themselves over to the folly of cowardice (unless, that is, they will it themselves), they cannot be kept from returning to their origin by any labour or difficulty or mischance of fortune. We will emerge victorious from every battle against things that disturb us" (196). The soul will return to God its father as to a terrestrial fire, and as it is illuminated by the rays of this light, it will come to knowledge of itself and all things inferior to it (bodies) and receive knowledge of heavenly and superior things (199).

The unhappiness of the soul as it falls into matter and forgetfulness, dying into a body where it is buried as in a tomb (201), is represented by the rivers of the underworld encountered by Aeneas. The Styx represents sorrow, the Cocytus mourning and the Phlegeton frenzy and madness (231). The darkness as we move away from the light at the opening of the underworld represents the movement from incontinence into intemperance, and from intemperance to the diseases of the soul. Citing Plato's Phaedo, Landino argues that because it is the body that leads the soul into these problems, one should not fear death; only the foolish suffer the dissolution of the body with anxiety (226). But the person embroiled in vice is in a state of discord with the self - pleasure pulls one way, avarice another, and idleness conflicts with ambition (227).

Among many suggestive parallels between Landino's version of Aeneas' journey through the underworld and $F Q I I$ the most important is that Charon the boatman, who brings Aeneas safely through the underworld to the Elysium Fields, represents grace (233). Landino links this idea to that of the purifying virtues, for those "purged in soul" do not use prudence to make a choice among things - they recognise nothing but true goods (233). Achieving this state of soul is a sign of grace, and it is this condition of soul that is the object of the journey.

At the end of his long exegesis of the Aeneid, Landino briefly praises his patron Lorenzo for his moderation in feasting, and abstinence from excessive consumption of wine, "as in the other aspects of temperance, Lorenzo, I think you are worthy of great praise" (239). What is quietly underlined at this point is that temperance is an essential quality in a leader. It is not a rhetorical flourish at the end 
of an exegesis of the Aeneid that has focussed largely on the virtue of temperance from a neo-Platonic perspective, but a logical conclusion to it - the ruler exemplifies the virtue whose significance has been expounded in the allegory, and this in turn reflects the Platonic view of the good ruler as one who reflects the model of the temperance of God. I will return to this point in the next chapter.

\section{Scriptural temperance - renewing the mind and Romans 12}

In the writers of the early church, neo-Platonic ideas join another stream in the broad braided river of temperance that comes from the New Testament, and thus already combine the Hebraic and Greek - a process begun in the books of the Apocrypha. Sophrosyne is used in the Greek New Testament in ways that reach back to the Greek origin of the word in the health of the phrenes (North 316). In the Gospels the association of sophrosyne with soundness of mind is clear in the healing of the man possessed by demons who is returned to his right mind when the spirits enter the Gardarene swine (Mark 5.15). In Acts 26.25, when Festus charges Paul with madness, he replies using sophrosyne for sanity. The Epistles refer to being "beside oneself" in contrast to being sophron (in 2.Corinthians.5.13); to the opposition between temperance and pride; and to thinking modest and mortal thoughts in relation to God's gifts (in Romans 12.3). Paul also associates sophrosyne with selfcontrol and mastery of the appetites, with sobriety and conjugal love (North 317).

But in Pauline ethics (especially as interpreted by the Protestant Reformation), having the right relationship to God is not the result of a journey up a ladder of increasingly pure virtues, but is the first and pivotal step in an ability to behave virtuously that is dependent on God's grace. Of particular importance to the thinking of Christian writers such as Augustine are the first three verses of Romans 12:

I beseech you therefore, brethren, by the mercies of God, that ye present your bodies a living sacrifice, holy, acceptable unto God, which is your reasonable service. And be not conformed to this world: but be ye transformed by the renewing of your mind, that ye may prove what is that good, and acceptable, and perfect will of God. For I say, through the grace given unto me, to every man that is among you, not to think of himself more highly than he ought to think; but to think soberly, according as God hath dealt to every man the measure of faith. (King James Version, Romans 12.1-3)

These three verses amount to a Christian reformulation of the Platonic view of God as the measure of all things, with self-knowledge based in knowledge of God, and with purification based in a turning away from material things. But now it is the 
right relationship with God, one based in humility, that is the proper and only basis for the rules for Christian behaviour that follow. The commentators in The Oxford Bible Commentary (under the heading "The Renewal of Your Minds") usefully explain the way these verses underlie Pauline ethics. The fitting human response to "God's extraordinary mercy" (of Romans 11.30) is

to present oneself wholly to God, from whom and through whom and in whom are all things (11:36). Offering 'your bodies a living sacrifice' connotes giving oneself continuously and entirely. Any lesser response misprizes the greatness of God's own offering. (1103-4)

And it is on this basis that the eschatological basis of Pauline ethics is built with the key injunction: 'Do not be conformed to this age." As the Oxford commentators explain, in the old order described in Romans 1.18-32, humans had "become futile in their thinking, and their senseless minds were darkened" (Romans 1.21). And so the “new, eschatological righteousness overmasters humanity's ancient, fallen nature.” It is through such "eschatological righteousness," a "return" or "conforming" to the original order and a "recreation of human minds" that:

believers experience a 'renewal of ... [their] minds, so that...[they] may discern the will of God - what is good and acceptable and perfect $(12: 2 b)$...Paul does not expect his readers to obtain such an exalted capacity on their own. Rather, he believes that as possessors of the Spirit, they are already equipped to live lives 'holy and acceptable to God' (12:1)...Paul asks only that they be what they truly are: righteous. (1104)

It is this Pauline approach that underlies the theology of Calvin and the approach to ethics introduced in Chapter Two of this study, according to which "the whole body of the faithful, as long as they live on the earth, must be like sheep to the slaughter, in order to be conformed to Christ their head," and that by raising their heads above earthly objects the faithful will be able to withstand any attack by "the wicked flourishing in wealth and honour." The division between the old order of temporal understanding and spiritual renewal underlies Augustine's division between the City of Man and the City of God and the Augustinian definitions of temperance previously discussed.

Given Spenser's preoccupation with Greek etymology in The Faerie Queene, it seems unlikely that he would not have been aware of the play on words in this important passage for Protestant theology. In Romans 12.3 we find a use of sophronein that is strongly suggestive for Spenser's treatment of temperance because of its association with metron, measure. This verse is something like a Christian equivalent to Plato's statement in the Laws that God must be the measure of all 
things, and that one like God is sophron and so dear to Him, and those unlike Him are not sophron but different and unjust. The English used by the translators of the King James' version for sophronein is "soberly" (in the sense I have previously explained in relation to the marriage service). The King James gives for Romans 12.3:

For I say, through the grace given unto me, to every man that is among you, not to think of himself more highly than he ought to think; but to think soberly, according as God hath dealt to every man the measure of faith. [The italics are included by the translators to indicate that "of himself" is not present literally in the Greek].

In the Greek of this verse there is a play on phronein - to think. Thus "not to think of himself more highly than he ought to think" translates me hyperphronein where hyper adds the connotation of thinking arrogantly - with hybris, or over-thinking, thinking too much, or more than one should. It is in this sense a variant of the Greek injunction to "think mortal thoughts", and is in Christian terms an injunction to intellectual humility. "Than he ought to think" translates par ho dei phronein (with the par ho indicating something like "concerning which") and here we find phronein directly. "But to think soberly," translates alla phronein eis to sophronein, and sophronein is the operative word for our purposes. "He should not think in an excessive (implicitly arrogant) way about the things he needs to think about, but with moderate (or temperate) thinking" renders the literal Greek more closely than the King James, and makes more transparent the link to intellectual temperance. The final part of the Greek, hekastoi hos ho theos emerise metron pisteos, could be translated more literally as "to each as the God shares out (or distributes) the measure of faith." The need to curtail arrogant thoughts relates to the gifts that differ "according to the grace that has been given to us," with every part of the body of Christ that is the church or Christian community performing different roles. Paul emphasises the need for a collective humility and unity to the church of Corinth, "the native habitat of spiritual pride and factional division" as the Oxford Bible Commentary explains this (1104).

The remaining eighteen verses of Romans 12 give the rules for Christian behaviour that underlie the Enchiridion of Erasmus and the sections of Calvin's Institutes presented in Chapter Two of this study. The rules are different in type from those of Aristotle and Cicero. According to Romans 12 and Pauline ethics, everyone should observe their different gifts as different parts of the same body in Christ, whether they are for prophesying, ministering, exhortation, teaching, ruling, or 
showing mercy. These activities should be done with simplicity and cheerfulness, love should be offered without dissimilation, evil abhorred. Brotherly affection and lack of sloth in business are commended, as are rejoicing in hope, patience in tribulation, prayerfulness, distributing the necessities of the saints, hospitality.

All these aspects of good Christian behaviour resonate strongly with FQII, and especially the House of Alma episode. The final verses of Romans 12 have particular application to Hamlet because they include the theological argument against the impulse to revenge. Thus verse 14 argues that good Christians should bless those that persecute them, bless and not curse. They should rejoice with those who rejoice and weep with those who weep. They should be of the same mind towards one another, and not mind high things but condescend to men of low estate. They should not be wise in their own conceits, they should recompense no man evil for evil, and provide things honest in the sight of all men, and as much as possible live peaceably with all men. And they should not avenge themselves, but give place unto wrath "for it is written Vengeance is mine; I will repay saith the Lord". Instead they should feed their enemy if he is hungry and give him drink if he is thirsty - this is the way to heap coals on his head. Any discussion of the justice or injustice of revenge in Hamlet in theological terms must be mindful of these explicit Biblical injunctions.

\section{Temperance and the Early Church Fathers}

Another strand of the treatment of temperance that is first seen in the Epistles and becomes important in the writing of the early Church Fathers (who in turn influence the theology of the Reformation) is the association of sophrosyne with hagiasmos purity (or sanctification). According to I Timothy 2.15 women will find salvation in childbearing, "if they persevere in faith (pistis) and love (agape) and purity (hagiasmos) with temperance (sophrosyne)" (North 318). In Thessalonians 4, the drunkenness of the pagans is contrasted with those called by God not to impurity but purity and sanctification (North 318). In a similar spirit, for Clement of Alexandria, conversion to Christianity replaces profligacy with sophrosyne, and Clement compares the drunkenness in Euripides' Bacchae with the sobriety of salvation (North 330). The need for purity in contrast to the pagans is a unifying theme in the treatment of sophrosyne of the early Church Fathers, but there are other variations. Clement alludes to a strongly intellectual aspect of sophrosyne, of the sort just seen in Romans 12.3, arguing that the object of the Christian Logos is not to make the soul 
epistemonikos (wise) but sophron (temperate) (North 329). Temperance is thus a direct result of the model of Christ. Sophrosyne also governs all the details of daily life in Clement, as it does for Cicero in De Officiis.

Most of the other Greek fathers develop aspects of sophrosyne that are intrinsically to do with moderation. For example, Tatian claims that the Christians surpass the pagan Greeks in sophrosyne, because Christian ethics are sophron while pagan ethics "contains much mania" (North 322). Philo Judeaus uses both Plato's image from the Phaedrus, of the horseman controlling the passions (325), and associates the Sixth and Tenth Commandments with sophrosyne (326). Of particular relevance to Hamlet, he sees Abraham's resignation at the death of Sarah as a mean between "apatheia and excessive mourning" (327). Of particular relevance to the opening of $F Q I I$ is Gregory of Nazianzus's view of the need in Christian belief for a mean between presumption and excessive humility or lack of hope (342).

There is also a strong, not to say fanatical, ascetic trend in some of the Fathers. Origen strongly favours virginity, equating it with martyrdom, believing the passions are the source of sin, and that apatheia may be achieved through fasting and celibacy (337). For Gregory of Nazianzus, virginity is the means of restoring the image of God, lost through sin, and hagnize sauton (purify thyself) replaces the Apolline Gnothi sauton to express Christian sophrosyne (342).

Gregory of Nyssa, finding sophrosyne in the Beatitudes, makes a variant of the Neoplatonic bathmoi (or ladder) a path to purity and martyrdom. The first beatitude "instills humility, because our downfall was the result of pride" (352). In the second beatitude meekness "makes us slow to turn towards evil" (352). Man can turn to sophrosyne or wantonness. For Gregory meekness involves apatheia, moderation and humility, but above all "control of the passions" (352). Sophrosyne is linked with katharotes, the imitation by mankind of the Divine purity, obtained by purgation (katharsis) of what is evil (352). Neo-Platonic purification and the Christian ascetic life are thus identified: "The aim of the ascetical life...is to restore the image of God in the human soul which has been obscured by sin. Because sin originates in uncontrolled passion and the domination of the soul by pleasure, the process of purification depends on the attainment of apatheia, the human imitation of the Divine attribute of freedom from passion" (346). So the Fourth Beatitude is interpreted as "Blessed is he who hungers for sophrosyne, for he shall be filled with katharotes, and this satiety will lead not to aversion, but only to greater desire" (352). In his interpretation of the Eighth Beatitude, Gregory equates sophrosyne and 
martyrdom: "Blessed are they who suffer persecution for justice's sake" (353). The torments of the martyrs heal the disease caused by pleasure. It is also important to note that in Gregory's view, divine grace is needed to achieve sophrosyne, which Gregory directly equates with the phrase in the Lord's Prayer: "Thy will be done." "When God's will is done, sophrosyne quenches the wanton and passionate impulses of the mind, humility destroys conceit, and moderation (metriotes) heals the disease of pride. To cure these ills is hard, and we need the help of God" (351).

\section{Clement, the pure garment of sophrosyne and the House of Alma}

Carol Kaske has previously demonstrated that the Church Fathers directly influence Spenser (96). In this section I will make a case specifically for the influence of Clement of Alexandria on the House of Alma episode. The effect of Spenser's allusion to Clement is, I would argue, to make us see the orientation of the House of Alma episode not only as that of the perfection of Aristotelian, Thomist, Stoic or Platonic self-control, but also as representing assimilation to God in the sense developed by Christian neo-Platonism. The body ruled by the soul is also the body offered in Pauline terms as a living sacrifice to God, and the soul itself is dear to God in a Platonic sense because sophron and so also (and the allusion to Platonic ideas of governance are very strong in this episode) just.

In the work of Clement, the Greek ideas of temperance previously discussed, the precepts "Know Thyself" "Nothing in excess" and "Think mortal thoughts", and the original sense of sophrosyne as health of mind, are brought together very directly with Christian ideas. In Clement there is little separation between rules for daily behaviour - of the type we have seen in Cicero's De Officiis - and assimilation to God; the two are clearly seen by Clement as aspects of the same thing. Assimilation to God is achieved both through the model of Christ and the cardinal virtues; one who is pure beholds God in a pure manner and so is assimilated to him. As in the First Alcibiades of Plato, sophrosyne is equated with self-knowledge by Clement the soul sees in itself its most Divine part, as in a mirror - and this corresponds to the paradigmatic stage of the neo-Platonic progress towards the One, when the human soul turns to the Divine. In the Stomateis (Miscellanies) Clement relates "gnothi sauton" ("knowing for what we are born") with the Beatitudes, saying that "he who becomes pure in heart (Matt.5.8) through gnosis is dear to God" (North 335). Clement also adopts from the Phaedo the idea that the practice of sophrosyne (in 
Clement's expression of this being content with natural desires) is a preparation for death and even martyrdom (335-6).

What resonates most strongly with the House of Alma episode is Clement's use of the Greek "pure garment of sophrosyne," a description Helen North describes as a commonplace of Greek writing and traces back to Prodicus' Choice of Heracles recorded in Xenophon's Memorabilia II.i (North 331). In the opening of Book III of the Paedagogus Clement claims, (and I will use here Helen North's summary and translation because it so effectively captures the centrality of temperance):

...the greatest lesson taught by the Logos is self-knowledge: if we know ourselves, we will also know God and be like Him in doing what is good and having as few needs as possible, and we will please God by wearing the pure garment of sophrosyne. (North 332)

This garment - in Greek, agnen stolen, sophrosynen - is the likely source of the garment Alma wears in Canto IX of $F Q I I$. Alma is described as "a virgin bright" (and Clement argues that God likes to see us bright with the ornament of intelligence [III.i]). She is "full of grace and goodly modestee, / That euen heuen reioyced her sweete face to see" (II.ix.18.8-9). The footnote in Hamilton's edition of The Faerie Queene to this canto argues: "Since the soul [Alma] is incorporeal, Alma herself is described as little as possible" (Spenser 238). Significantly, then, the entire following canto is dedicated to Alma's clothing and the dressing of her hair.

In robe of lilly white she was arayd,

That from her shoulder to her heele downe raught,

The traine whereof loose far behind her strayd,

Braunched with gold and perle, most richly wrought,

And borne of two faire Damsels, which were taught

That seruice well. Her yellow golden heare

Was trimly wouen, and in tresses wrought,

Ne other tire she on her head did weare,

But crowned with a garland of sweete Rosiere. (II.ix.19.1-9)

Initially it would seem as if Alma's "robe of lilly white" is everything that Clement would reject in a garment, as a robe that is long and embroidered with gold. But it should then become apparent that for Spenser, as for Clement (and as a typically witty Spenserian point), this ornamented garment is metaphorical. In the previous section Clement has written, "for those women who have been trained under Christ, it is suitable to adorn themselves not with gold, but with the Word, 
through whom alone the gold comes to light" (Clement 269; II.xiii). The embroidery of gold and pearls in Spenser in this way directly answers the injunction in the epistles not to be decorated with gold or pearls or with the braiding of hair, for these are not literal gold or pearls or hair-styling. Alma's hair is "trimly wouen" and garlanded with "sweete Rosiere" (which Walter R. Davis has interpreted as a symbol of divine love [24]). In adopting the metaphorical approach of Clement, Spenser is dressing Alma, the human soul, in both the wisdom and love of the Word, the Divine Logos. With attendants holding her train (Hamilton's notes here suggest the now dutiful concupiscent and irascible parts of the soul) she is prepared like the bride of Christ (Davis 24). As Clement moves straight from "the pure garment of sophrosyne" to the rational, irascible and concupiscent divisions of the soul, this interpretation chimes with Clement's approach.

It is the metaphysical implications of Spenser's portrayal of Alma that become most interesting when placed next to these passages in Clement. While for Clement, "lust becomes and fabricates all things, and wishes to cheat, so as to conceal the man" (271; III.i.), the opposite is true of the man "with whom the Word dwells" (271, III.i).

But that man with whom the Word dwells does not alter himself, does not get himself up: he has the form which is of the Word; he is made like to God; he is beautiful; he does not ornament himself: his is beauty, the true beauty, for it is God; and that man becomes God, since God so wills. Heraclitus, then, rightly said, 'Men are gods, and gods are men.' For the Word himself is the manifest mystery: God in man, and man God. And the Mediator executes the Father's will; for the Mediator is the Word, who is common to both - the Son of God, the Saviour of men; His servant, our Teacher. And the flesh being a slave, as Paul says, how can one with any reason adorn the handmaid like a pimp? (271; III.i)

The ultimate consequence of the adoption of human flesh by the Word is immortality: "the compassionate God Himself set the flesh free, and releasing it from destruction, and from bitter and deadly bondage, endowed it with incorruptibility, arraying the flesh in this, the holy embellishment of eternity - immortality" (271, III.i). The other aspect of this true beauty is love: "For truth calls that its own which belongs to it; but the love of finery seeks what is not its own, being apart from God, and the Word, from love" (271, III.i). To make the difference between literal and metaphorical appearance completely explicit, Clement cites Isaiah on the appearance of the Messiah:

And that the Lord Himself was uncomely in aspect, the Spirit testifies by Esaias: 'And we saw Him, and he had no form or comeliness; but His form 
was mean, inferior to men.'... But it was not the beauty of the flesh visible to the eye, but the true beauty of both soul and body, which He exhibited, which in the former is beneficence; in the latter - that is, the flesh - immortality. (272; III.i)

Thus if Alma wears the pure garment of sophrosyne, she also wears immortality, and we must read her portrayal in primarily spiritual terms. Spenser's Alma, "faire, as faire mote euer bee, / And in the flowre now of her freshest age" (II.ix.18.6-7) also demonstrates "beneficence," entertaining her guests with "gentle court and gracious delight" (II.ix.20.3). The repeated play on grace in her description - as well as entertaining with "gracious delight" she is also "full of grace" (II.ix.18.8) - underlines the spiritual qualities of this soul robed in the "lilly white," that is Spenser's variant on Clement's "pure garment of sophrosyne." She is clothed in the immortality that comes from the Word, and this also makes her humble in her "lilly white," like the gospel lilies of the field, needing nothing which the heavenly father does not provide. What we are seeing in the portrayal of Alma is the active effect of the Word on the soul.

Like Spenser, Clement also has an opposed vision of the impure woman who clothes herself with artifice. Spenser's Acrasia wears almost nothing, and in this sense parodies the Alma whose clothes are not literal but metaphorical. Acrasia's clothes draw attention to the body, in the manner of the bad woman in Xenophon's legend of Heracles (Memorabilia II.i.30). She:

was arayd, or rather disarayd, All in a vele of silke and siluer thin, That hid no whit her alablaster skin, But rather shewd more white, if more might bee: More subtile thread Arachne cannot spin, Nor the fine nets, which oft we wouen see Of scorched deaw, do not in th'ayre more lightly flee. (II.xii.77.3-9)

The "pure Orient perles" (II.xii.78.5) that drip down Acrasia's "snowy breast" (II.xii.78.1) are in fact nothing to do with purity, but are the beads of sweat from her "late sweet toyle" (II.xii.78.3) with her captive young swain, Verdant. For Clement, the soul is to be decorated with the ornament of goodness, the flesh with the adornment of temperance. But "those women who beautify the outside, are unawares all waste in the inner depths" (Clement 272; III.ii). Clement compares such women with highly ornamented Egyptian temples which contain a cat or crocodile or snake 
to worship. So, "if one withdraw the veil of the temple - I mean the head-dress, the dye, the clothes, the gold, the cosmetics, - that is, the web consisting of them, the veil, with the view of finding within the true beauty, he will be disgusted, I know well. For he will not find the image of God dwelling within, as is meet; but instead of it a fornicator and adulteress has occupied the shrine of the soul" (272; III.ii)

The underlying dichotomy Clement is establishing is that of 2 Corinthians 4 . 18: "while we look not at the things which are seen, but at the things which are not seen: for the things that are seen are temporal; but the things that are not seen are eternal." The work of this study, particularly on Augustine's treatment of temperance, has made unavoidable the conclusion that the profound Christian dichotomy between the carnal and the spiritual underlies Spenser's approach to temperance in FQII. Acrasia and the Bower of Bliss represent the things that are seen and that are, almost by definition, full of deception. Alma in her metaphoric gown of sophrosyne represents the things of the spirit that are not seen but that are nevertheless real and true. The key (in this theological approach) that unlocks the things that cannot be seen and makes the understanding receptive to the things of the spirit is the Word. And in lock-step, as it were, with this development of understanding, goes the need to move the self away from the things of this world. Explicitly for Clement, commenting on the myth of Phaeton, what guides reason away from the dangers of pleasure is the Word. "Heaven delights in two charioteers, by whom alone the chariot of fire is guided. For the mind is carried away by pleasure; and the unsullied principle of reason, when not instructed by the Word, slides down into licentiousness, and gets a fall as the due result of its transgression. An example of this are the angels, who renounced the beauty of God for a beauty which fades, and so fell from heaven to earth" (274; III.ii).

In other words, Clement's theological approach to temperance is that the mind will escape from being directed to pleasure only when it is first directed by the Word.

\section{Augustine, temperance and Pauline spiritual renewal}

Augustine's treatment of temperance - particularly in his earlier theology - contains strong echoes of neo-Platonism. Following in the spirit of earlier patristic writers like Clement who combine classical and Christian, Augustine associates temperance, assimilation to God and Pauline ethics - the removal of conformity to the world, and the spiritual renewal that enables proving "that good, and acceptable and perfect will 
of God". Augustine's central definition of temperance in De Moribus Ecclesiae is "love giving itself entire and incorrupt to God" (Augustine, 15.25). Romans 12.1-2, which, as we have seen, demands that "ye present your bodies a living sacrifice, holy, acceptable unto God which is your reasonable service" helps us understand what temperance as "love giving itself entire and incorrupt to God" might mean in Augustine. In the early De Musica and De Ordine temperance is strongly associated with a neo-Platonic return to God as the One and strong overtones of this view of temperance remain in the Confessions.

In the final book of the Confessions, Augustine develops a reading of the first week of creation of the Genesis story as that of the formation of the Church, and draws strongly on the dichotomy between the transitory world and the spiritual renewal of Romans 12.1-2 as he does so. In this allegory, the wild animals, and beasts and serpents of the Genesis story "signify the affections of the soul," and must be subdued through the both ethical and spiritual process of not being conformed to the world. The three-fold sins of 2 John. 10 -"the haughtiness of pride, the pleasures of lust, and the poison of curiosity" - are seen as "the passions of a dead soul", and this spiritual death comes about when the soul departs from the Word, "fount of eternal life" - with the consequence "that it is absorbed by the transitory world and conformed to it" (291; XIII. xxi.[30]). What counters this movement away from the spiritual fount is the message of the Word - the message of Romans 12.2: "By your Word through your evangelists the soul achieves self-control by modelling itself on the imitators of your Christ" (291; XIII.xxi. [31]).

This "living soul," the dry land that emerges from the bitter waters of creation, is the Church - the community of the faithful. Along with this process of Pauline spiritual and ethical transformation is a Christian version of assimilation to God. The believer should not be conformed to the world, because in Genesis 1:26 humankind was made after the likeness of God. Paul "who generates sons by the gospel and does not wish to have permanently immature believers fed on milk and cherished as if by a nurse, says 'Be renewed in the newness of your mind to prove what is God's will, which is a thing good and well-pleasing and perfect"' (292; XIII. xxii. [32]).

The imagery of the believer as spiritually immature and needing to be fed on milk and not meat comes from Paul's admonitory words to the Corinthians (1.Corinthians.3:1-2), who have regressed to squabbling among themselves and to other forms of moral backsliding. The believer who requires such spiritual 
sustenance and who is at risk of wandering away from God has been the subject of the first nine books of the Confessions - the story of the spiritual journey, from a neo-Platonic falling away from the One, and the return to God through conversion of Augustine himself.

\section{The Confessions and the journey of the soul to spiritual "weakness"}

The first nine books of the Confessions provide another model of the spiritual journey based on the epic, in addition to the neo-Platonic one we have seen in Landino. Like Odysseus returning to Ithaca, or Aeneas leaving Troy to found a new Troy in Rome, Augustine's journey is a meandering one to many places. It is also a spiritual journey away from and back to God, drawing on the language of neoPlatonic descent into matter and return to the One; the Scriptural parable of the Prodigal Son who finds himself eating the husks of the food for the pigs; and the Old Testament imagery of idolatry as adultery or fornication against God (87; V.xii [22]). There are some direct echoes of this spiritual journey in FQII. At the end of Book II of the Confessions, Augustine describes finding himself in a spiritual location that echoes the neo-Platonic writer Porphyry: "As an adolescent I went astray from you, my God, far from your unmoved stability. I became to myself a region of destitution" (34; II.x [18]). Approaching the Cave of Mammon, the locus of the material, Spenser's Guyon finds himself travelling through "wide wastfull ground, / That nought but desert wildernesse shewed all around" (II.vii.2.8-9).

Augustine later describes this distance as a fall away from God, again in language with echoes of the neo-Platonic descent into matter. "I slipped down into the dark and was plunged into obscurity" (251; XII. x [10]). But like the Palmer who is reunited with Guyon at the opening of Canto VIII by a calling voice, Augustine is returned by love. "Yet from there, even from there I loved you. I erred and I remembered you. I heard your voice behind me calling me to return" (251; XII.X [10]). Augustine's journey away from God and his return to God is structured on the dichotomy between pride and humility, and the only path back to humility for the Christian is the divine weakness of the divine incarnation, and the need for a complete submission to that weakness. Augustine describes the Incarnation as building a humble house of human clay, and a detachment by which those willing to be made Christ's subjects are "carried across" to him, their proud swelling healed and their love nourished. "They are no longer to place confidence in themselves, but rather to become weak. They see at their feet divinity become weak by sharing in our 
coat of skin. In their weariness they fall prostrate before this divine weakness which rises and lifts them up" (128; VII.xvii [24]).

Part of Augustine's distance from God had been based on his rejection of the Bible in favour of classical writers like Cicero. "Yet the Bible was composed in such a way that as beginners mature, its meaning grows with them. I disdained to be a little beginner. Puffed up with pride, I considered myself a mature adult" (40; III.v [9]). It is the spiritual exegesis of Bishop Ambrose, the Pauline "angel of God" (91; VI.i [I]) who helps Augustine to finally penetrate the inwardness of the Scriptural message. And so the pride of his intelligent reading of texts like Aristotle's Ten Categories is compared unfavourably with a more humble faith. "[W]hat serious harm did it cause to your little ones that their intelligence was much slower? They did not wander away far from you. In the nest of the Church they could grow like fledglings in safety and nourish the wings of charity with the food of sound faith" (71; IV.xvi [31]).

\section{Journeying towards temperance or wandering away from God}

If we follow the model of the journey of the soul seen in Landino, we will see Guyon's journey as something like that of Aeneas. It begins with much grief. As Aeneas weeps at the Fall of Troy, Guyon weeps at the story of Amavia and over the Bloody Babe, as at a loss of innocence in the discovery of the Fall of Humankind. But gradually Guyon will progress, like Aeneas in Landino's exegesis (with some lapses from continence to incontinence and back again) in a forward movement towards the stage of the purgative virtues and ultimately to temperance, portrayed in the House of Alma and the ultimate triumph of the destruction of the Bower of Bliss. But if we follow the pattern of the Confessions we will see something different - the danger of misunderstanding the message of Gospel hope offered by the Word, just as Augustine failed to understand the depth hidden behind its apparent simplicity, and the danger of wandering away from God, the source of true temperance.

The central icon of the Legend of Temperance is the carrying of the babe with blood-stained hands. In the Letter to Raleigh the subject of Book II is described in the following way: "the second day ther came in a Palmer bearing an Infant with bloody hands, whose parents he complained to haue bene slayne by an Enchaunteresse called Acrasia" (Spenser 717). The Biblical source for this carrying or bearing is 2 Corinthians 4.10: "Always bearing about in the body the dying of the Lord Jesus, that the life of Jesus might be made manifest in our body." This Pauline 
text could also be seen as a Christian statement of temperance; in Christian terms what the reformation of body and soul requires. The Palmer carries the Babe whose hands are stained both with the concupiscence of original sin and with the blood of the redemption of that sin. The prayer that opens the Confessions combines the message of 2 Corinthians 4.10 (among other verses) with a Christian variant on neoPlatonic desire for union with the One.

\begin{abstract}
Man, a little piece of your creation, desires to praise you, a human being bearing his mortality with him, carrying with him the witness of his sin and the witness that you resist the proud. Nevertheless, to praise you is the desire of man, a little piece of your creation. You stir man to take pleasure in praising you, because you have made us for yourself, and our heart is restless until it rests in you. (3; I.i [I])
\end{abstract}

When Guyon picks up the Babe at the beginning of Canto II of $F Q$ II, and so enacts the iconography of the Letter to Raleigh, carrying the Babe with bloodstained hands in his arms, he does not have the deep humility and Christian self-knowledge shown in this opening prayer of Augustine. Instead he sees only rejection and abandonment. This despair encapsulates his own spiritual condition at this point.

Poore Orphane in the wide world scattered,

As budding braunch rent from the natiue tree,

And throwen forth, till it be withered:

Such is the state of men: Thus enter we

Into this life with woe, and end with miseree. (II.ii.2.5-9)

If, as we have seen in Clement and Augustine, Christian temperance and selfknowledge comes from the Word, what Guyon is failing to see is the measure of Christian hope that also comes from the Word. And Spenser is presenting this failure quite directly, as Guyon is misrepresenting the message of Gospel hope of John 15 a passage which makes a quite opposite promise. That verse makes clear that it is only those who fail to abide in the vine that is the Father who will be thrown forth until they are withered and cast into the fire. Those who abide in Christ will not only be kept safe, they will also bring forth much fruit. The spiritual condition evinced by Guyon at this point is very like that of the Hamlet who proclaims that all the uses of the world are weary, stale and unprofitable, and that the world is an unweeded garden that grows to seed. The imagery of abandoned husbandry also features in the Elizabethan homily "Of the declining from God", and this sermon gives a version 
contemporary with Spenser of Augustine's preoccupation with the danger of falling away from God.

The sermon contains some chilling doctrine. It thunders that God will first manifest his displeasure overtly to those who do not remain in the faith, with plague and famine and other manifestations of his wrath. But more subtly God will also quietly remove his affection and support from those who have strayed away, so that they are not even conscious of its loss. What is at stake, for the believer, is a participation in the mercy of Christ that echoes the assimilation to God we have just seen in the early Church Fathers:

GOD hath shewed to all them that truely beleeue his Gospel, his face of mercie in Iesus Christ, which doeth so lighten their hearts, that they (if they behold it as they ought to doe) be transformed to his Image, be made partakers of the heauenly light, and of his holy Spirit, and bee fashioned to him in all goodnesse requisite to the children of GOD. (Declining, Pt 1)

Opposed to being transformed to the Image of Christ is the loss of his "holy word",

if they after doe neglect the same, if they bee vnthankefull vnto him, if they order not their liues according to his example and doctrine, and to the setting forth of his glory, he will take away from them his Kingdome, his holy word, whereby hee should reigne in them, because they bring not foorth the fruit thereof that he looketh for. (Pt 1)

They will be like the peoples of the Old Testament who ignored the warnings of the prophets and so were "scattered into all kingdomes which they neuer knew, and their land was made desolate" (Pt 1). The wording anticipates Guyon's description of Ruddymane as the "poore Orphane" who is "in the wide world scattered, / As budding braunch rent from the natiue tree" (II.ii.2.5-6). While a range of causes is given (some to do with failures of temperance), for people not abiding by the word of God but following their own persuasions, going backwards and not forwards, so that "they goe and turne a way from GOD", the primary cause is moving away from the message of the Word. Those who with their minds, study, deeds, thought and care apply themselves to God's word, and think about his Laws day and night, and give themselves wholly to his precepts and commandments, are turned to God. But those who in the time for thinking about God's word are instead thinking about worldly business, money and lucre are turned from God; those entangled with possessions, covetousness of riches, or who study for the glory and honour of this world, are turned from God (Pt 1).

When Guyon enters the desolate landscape of the Cave of Mammon, he is in the kind of spiritual world that belongs to one so preoccupied. Guyon denounces 
worldly goods (but not glory and honour, and whether of the world or not is not clear), but he still enters the Cave. In terms of Augustine's denunciation of curiosity as a form of intemperance in De Moribus Ecclesiae, what he is clearly doing is replacing the contemplation of the spiritual with the curiosity and concupiscence of the eyes. He is not, in other words, thinking about God's word. The Elizabethan homily gives God's response to such behaviour. God may show great wrath or he may turn and hide his face. And this withdrawal involves the loss of scriptural comfort: "But when he withdraweth from vs his Word, the right doctrine of Christ, his gracious assistance and ayde (which is euer ioyned to his word) and leaueth vs to our own wit, our owne will and strength: he declareth then, that he beginneth to forsake vs" (Pt 1). But all is not lost as yet and it is this intermediary stage that is so important to understanding the purposes of Spenser's allegory in FQII.

But when we begin to shrinke from his word, not beleeuing it, or not expressing it in our liuings: first hee doeth send his messengers, the true preachers of his word, to admonish and warne vs of our duetie: that as hee for his part, for the great loue hee bare vnto vs, deliuered his owne Sonne to suffer death, that wee by his death might be deliuered from death, and be restored to the life euerlasting... so againe, that we for our parts shoulde walke in a godly life, as becommeth his children to doe. (Pt 1)

That this intermediary stage, the role of the preacher in rescuing the spiritual child who might stray from God, was of high importance to the reformers among the Elizabethan clergy was made clear when Queen Elizabeth sought to suppress the socalled practice of "prophesying" (a kind of formal explication of the scriptures in a public forum) and refused to appoint more preachers (Collinson, Elizabethans 242). Archbishop Grindal risked disfavour and worse, citing Ambrose in his defence (and so consciously acting as a sophronistes) to admonish Queen Elizabeth in a letter. What, according to Grindal, is at stake for the Elizabethan church, the kingdom and the Queen is the risk of declining away from God through lack of messengers of the Word.

God hath blessed you with great felicity in your reign, now many years; beware you do not impute the same to your own deserts or policy, but give God the glory...Take heed, that ye never once think of declining from God...For if ye turn from God, then God will turn away his merciful countenance from you. And what remaineth then to be looked for, but only a terrible expectation of God's judgements, and an heaping up of wrath against the day of wrath? (Nicholson 390)

It is only for those who do not heed either God's wrathful or gentle warnings that God will destroy his vineyard, and will no longer "dig and delue" (Pt 2) around 
them, as the Elizabethan homily pronounces. Not to heed such warnings is a sign of carnal liberty. Those people who are so heedless "take it for a great benefit of GOD, to haue all their owne libertie: and so they liue, as if carnal libertie were the true libertie of the Gospel" (Pt 2). It is this risk that surrounds Guyon, who first cannot interpret and apply a Gospel message of hope, that of John 15, and then proceeds as if the consequences of the loss of such hope do not apply to him, cheerfully giving advice on temperate behaviour to others. He requires the temperance of Gregory of Naziansus - between lack of hope on the one hand and presumption on the other.

The good Christian who, in the spirit of 2 Corinthians 4.10, will always bear about in the body the dying of the Lord Jesus Christ (so that death will work in them but life in Christ) will, explicitly and for this reason, "faint not." While the outward man of 2 Corinthians 4.10 may perish, the inward man is renewed day by day and this happens "while we look not at the things that are seen, but at the things that are not seen; for the things that are seen are temporal; but the things which are not seen are eternal." That Guyon faints on emerging from the Cave of Mammon signals that his inward man has urgently needed renewal while he was feasting his eyes on the things that are seen. The beautiful homiletic stanzas that open Canto VIII are full of comfort about God's abiding and abounding mercy, and they directly answer Guyon's despairing view of the Babe (and by implication himself) as one abandoned and orphaned. He has been returned like a prodigal to his father's care. But we should also not underestimate the level of admonition in these two stanzas. Blessed angels are sent to "wicked man, [God's] wicked foe" (II.viii.2.9). And the speaker asks despairingly, "O why should heuenly God to men haue such regard?" (II.viii.2.9). The despair is Pauline, that of the Paul who admonishes the Corinthians that he has had to feed them with milk and not meat because they were unable to receive the food of the Gospels: "neither yet are ye able."

Augustine in De Diversis Quaestionibus (1.6) establishes a particular category for the carnally-minded believer who needs to be fed with milk and not meat. To be carnally-minded in a general and entirely negative sense is to fail to see the world spiritually, and to be trapped (in the way Carol Kaske argues for Mordant) so that the injunctions of the Law become an active incentive to sin. But there is a specialised category for the parvulus, the little ones who like the young church of the Corinthians are as yet insufficiently spiritually strengthened. Clement gives a similar definition: "the carnal may be understood as those recently instructed, and still babes in Christ. For he calls those who had already believed in the Holy Spirit spiritual, and 
those recently instructed and not yet purified carnal; whom with justice he calls still carnal, as minding equally with the heathen the things of the flesh" (218; I.vi). What is concealed from the "wise and prudent" of the present world is revealed only to babes.

It is for these reasons that the parvulus deserve an especial protection, as seen in the injunction in Matthew 18.10 for those "little ones" whose "angels look upon my father which is in heaven". But those still carnal in this technical sense of newly instructed face a very specific risk, one with which Augustine is often concerned. That is the risk of falling away from God through a failure to see beyond the literal text of the Bible to its hidden spiritual depths, or in misinterpreting one text failing to reconcile it with another and so going astray. It is for such little ones that the safety of the "nest of the Church" is most required. And this is the case for Guyon, who, I am arguing, has gone astray early in his own legend misinterpreting a Gospel message of hope.

Towards the end of the Confessions (and in the Book concerned with God the Son and the message of the Word), as Augustine expounds a spiritual interpretation of the words of creation of Genesis, he remembers such believers (such as he himself once was) and the danger that, reading the descriptions of God's actions of creation as happening in time and space, they might find this to so strain credulity as to reject the message altogether. ${ }^{4}$ For these he prays for divine aid for the little one who like an unfledged baby bird has fallen from the nest of faith: "Lord God, have mercy...Send your angel to replace it in the nest so it can live until it can fly" (267; XII.xxvii [37]). Spenser's sequence of Guyon's faint replicates this prayer quite precisely. Guyon is described as a "chicken newly hatcht" (II.viii.9.9). The Palmer's hands "cour" ("cover" but with a play on "cor" heart) his pulse as the Christ of Matthew 23.37 is portrayed as a mother hen protecting her chickens. And an angel also descends to his rescue, an angel sent by the God whose mercy has just been described. Seen in the light of Augustine's prayer, and the Elizabethan homily that warns against declining away from God, this angel offers a Scriptural rescue, a rescue that comes through a messenger of the Word, or that is the Word.

John Michael Owen in "The Angel of the great counsel of God and the Christology of the Scots' Confession of 1560" explains a long tradition of translating

\footnotetext{
${ }^{4}$ A version of this section has been presented as an unpublished paper. Gillian Hubbard, "Augustinian nests and Guyon's faint," Spenser at Kalamazoo sponsored session, $41^{\text {st }}$ International Congress on Medieval Studies, Kalamazoo, 5 May 2006.
} 
megales boules aggelos in the Septuagint version of Isaiah 9.6.5 as "angel of great counsel of God." In the Scottish Confession of 1560 it is used as part of the description of the birth of Christ: "and sa was borne of the iust seid of Dauid / the Angell of the greit counsel of God the uerray Messias promesit" (306). In the early Church Fathers, this description of Christ relates to his teaching ministry; he was the messenger who delivered Christ's counsel as the Incarnate Revealer, the angel, as God's Word who delivers Jacob by revealing the Father (349). Owen explains that in specified Church Fathers the "Angel of great counsel" does not refer to the "preexistent Son of God" but rather "the role of the Word Incarnate in mediating and effecting God's revelation and salvation to human beings" (312). This is completely consonant with the appearance of the angel in Spenser's passage, who appears to deliver the mercy of God described in the opening stanzas of the canto. Calvin describing Christ as a teacher says, "he was given to human beings as the "Angel of great counsel' (Is.9:6)" (qtd Owen 314).

To see this angel as the Word delivering the hope of the Divine Incarnation is (paradoxically perhaps) reinforced by the allusions in this passage to the Aeneid. The opening two stanzas of Canto VIII give a Christian answer to the famous question near the opening of the Aeneid (1.11) when Aeneas and his boats are sent astray: "How can there be so much rancor in heavenly hearts? (tantaene animis caelestibus irae?)" Spenser says: "And is there care in heauen? and is there loue / In heavenly spirits to these creatures bace, / That may compassion of their euilles move? / There is: else much more wretched were the cace / Of men then beasts" (II.viii.1.1). When the calling voice restores the Palmer to Guyon, there may also be a weak echo of some other famous words of the Aeneid. When Dido asks Aeneas to retell the story of Troy, he replies (2.3): "You ask me, O Queen, to renew an inexpressible pain (infandum...dolorem)". The angel tells the Palmer, specifically for the individual life of Guyon that hangs in the balance, but also more generally and in an annunciatory way for all humankind: "dread of death and dolour doe away" (II.viii.7.7). This not only answers the despair of the opening of the Aeneid about the carelessness of the gods, but the suicidal despair of Amavia that opens $F Q I I$, the despairing vision that portrays Amavia as a "sad pourtraict / Of death and dolour" (II.i.39.4). It has been the mission of the first part of this journey of $F Q I I$, in other words, to overcome and replace "dread of death and dolour" with the Scriptural hope in a promised eternity, which cannot be seen but to which Christian temperance must be orientated if the body is to become the "living sacrifice" of Romans 12.2, and if the mind is to be 
renewed (to be "newly hatcht") to know what is God's will. Only then can it move to the fruits of the spirit that include temperance and joy.

And this is what happens when faith is restored to temperance. The Palmer, we are told, "much reioyst" (II.viii.9.8) when he found Guyon's life "not yet dislodged quight" (II.viii.9.7). The "not yet...quight" conveys the immediacy of risk - with “dislodge" suggesting Augustine's image of overturning out of a nest. When Guyon awakes after Arthur has battled with the forces of intemperance - portrayed in terms of birds of prey (and in Augustine's De Ordine the powers of the air seek to impede the ascent of the soul to God and are defeated by temperance) - he exclaims to the Palmer, "I ioy thy face to vew; / Firme is thy faith, Whom daunger neuer fro me drew" (II.viii.53.8).

\section{The Platonic soul, the ruler, and the harmony of the universe}

The Pauline fruits of the spirit are seen in the House of Alma, in the temperance and beneficence of the soul properly orientated to God and the things of the spirit, a soul dressed, as we have seen, in the "pure garment of temperance (sophrosyne)." The soul properly orientated to God includes in its memory the Divine Incarnation, as does Alma in her turrets (although well hidden amongst temporal history). “[T]h' eternall Lord in fleshly slime / Enwombed was, from wretched Adams line / To purge away the guilt of sinfull crime" (II.x.50.2-4). This action of purging is enacted by Arthur in his battle with Maleger, who represents something like the "diseases of the soul" that develop from intemperance, the Pauline "body of this death," from which Christ will deliver the believer.

Spenser's portrayal of Alma, the ruler of her castle as the soul rules the body, combines the Pauline with the Platonic. It also associates temperance with justice. Harry Berger argues: "it is clear that temperance must be conjoined to justice, and intemperance to injustice, that the health of the inside and the health of the outside are inseparable. Christian temperance must be displayed at once as a limited cardinal virtue, and as the broad harmony inherited from Platonic sophrosyne"(154). The emphasis on the divine foundations of government in Plato's thought is in turn influenced by the Pythagoreans. In Iamblichus's Life of Pythagoras government rests on a divine foundation, and "the rule of the gods is justified by man's inclination to hybris, which must be corrected by sophronismos and taxis" (North 235). Early Pythagorean writing also suggested that the king must be to the state as God is to the universe and so the king must bring about harmony within himself. The king must 
achieve independence (autarkeia) which makes one self-restrained, and must avoid extravagance, the source of hybris (North 235-7). Sophrosyne in the state is thus implicitly linked to the imitation of God.

In Canto IX of FQII Spenser establishes a dichotomy between the fortified castle of the self and the attacking hordes of Maleger in terms of governance:

Of all Gods workes, which doe this world adorne,

There is no one more faire and excellent,

Then is mans body both for powre and forme,

Whiles it is kept in sober gouernment;

But none then it, more fowle and indecent,

Distempred through misrule and passions bace:

It growes a Monster, and incontinent

Doth loose his dignity and natiue grace.

Behold, who list, both one and other in this place. (II.ix.1.1-9)

The role of the soul as monarch is reinforced at the opening of Canto XI. These two opening cantos, with their reference to the "fraile flesh," and "sinfull vellenage," sound more Pauline than Platonic.

What warre so cruel, or what siege so sore,

As that, which strong affections doe apply

Against the forte of reason euermore,

To bring the sowle into captiuity:

Their force is fiercer through infirmity

Of the fraile flesh, relenting to their rage,

And exercise most bitter tyranny

Vpon the partes, brought into their bondage:

No wretchednesse is like to sinfull vellenage. (II.xi.1.1-9)

The Pauline pessimism of this view of the "fraile flesh" and "sinful vellenage" is then replaced with a more Platonic-sounding note about the potential triumph of rational self-control.

But in a body which doth freely yeeld

His partes to reasons rule obedient,

And letteth her that ought the scepter weeld,

All happy peace and goodly gouernment

Is setled there in sure establishment, 
There Alma like a virgin Queene most bright,

Doth florish in all beautie excellent:

And to her guestes doth bounteous banket dight,

Attempred goodly well for health and for delight. (II.xi.2.1-9)

There is a tension between the Pauline pessimism of "sinfull vellenage" and the more Platonic-sounding triumphant rational self-governance. Again, just as Guyon cheerfully announces the solution of the "golden squire" at the opening of the legend, it appears that the harmonious governance of the soul is also easily and cheerfully achieved. The insufficiency of such optimism is shown in the allegory by the continued need for the Castle of Alma to combat the attack of the hordes of Maleger. What the remainder of Canto XI portrays is less the supremacy of rational selfcontrol than the victory of the Word through the sacraments of baptism and communion.

In the threefold nature of the attempt of Arthur to defeat Maleger (which echoes Redcrosse's battle with the dragon) Arthur is finally successful only when he casts the body of Maleger into a standing lake, an act usually taken to represent baptism and the death of the "old man." This lake may be the Biblical Pool of Bethesda, a body of water linked through patristic and later Catholic and Lutheran exegesis with baptism and the victory of grace over the Mosaic Law. ${ }^{5}$ Arthur is then returned to the castle of the soul with the help of a squire (identified with grace in the passage of the wrestling match), and, bleeding heavily like the wounded Christ on the cross, is taken down in a scene reminiscent of a deposition from the cross. The final stanza of this canto is in turn strongly reminiscent of the Corpus Christi carol, in which a loving maiden weeps over a Knight then identified with the body of Christ of the Catholic mass. The carol, which describes through allegory Christ's redemption offered through the mass, concludes in the following way:

III

And in that hall ther was a bede,

Hit was hangid with gold so rede;

IV

And yn that bed ther lythe a knight,

His wowndis bledying day \& nyght;

5 An expanded version of this argument has been presented as an unpublished paper. Gillian Hubbard, "The pool of Bethesda and The Faerie Queene," Victoria University School of English, Film, Theatre and Media Studies Postgraduate Conference, Wellington, 13 July 2008. 
By that beddis side ther kneleth a may,

$\&$ she wepeth both nyght \& day;

VI

$\&$ by that beddis side ther stondith a ston,

'Corpus Christi' wretyn ther-on. (Parker 5)

Arthur is led to the Castle by a beaten way, suggesting the straight path and broad gate to salvation.

Where many Groomes and Squyres ready were,

To take him from his steed full tenderly,

And eke the fayrest Alma mett him there

With balme and wine and costly spicery,

To comfort him in his infirmity;

Eftesoones shee causd him vp to be conuayd,

And of his armes despoyled easily,

In sumptuous bed shee made him to be layd,

And al the while his wounds were dressing, by him stayd. (II.xi.49.1-9)

Arthur, to make this explicit, has fought for his lady, Alma, the Christian soul, as Christ for the Church through the crucifixion and resurrection. Having in the space of two cantos conveyed the Divine Incarnation (announced as previously noted as if hidden in the Histories of Briton) and the sacraments of Baptism and Holy Communion (the Reformed Church's variant of the Mass), Spenser has established a different basis for the temperate soul than that of Platonic governance. This basis is the bedrock of Christ as head of the Church. So the opening of Canto XII announces triumphantly:

Now ginnes this goodly frame of Temperaunce

Fayrely to rise, and her adorned hed

To pricke of highest prayse forth to aduaunce,

Formerly grounded, and fast setteled

On firme foundation of true bountyhed. (II.xii.1.1-5)

Given this triumphant opening of Canto XII, the expectation might now be that the progress of Guyon and the Palmer to the Bower of Bliss will essentially enact in another way Arthur's victory over Maleger, in the way that Redcrosse's victory over the dragon portrays in a folktale style the victory over pride that has 
already preceded it. But like the ending of the Aeneid, the triumphant ending of FQII is more problematic. Another way of seeing the victory of Canto XI is as an episode establishing an ideal of temperance from which the reality then, as it were, rows away towards the Bower of Bliss and its problematic attempt to restrain concupiscence. And so I will return to re-examine the aspects of $F Q I I$ that relate to epic journeying.

\section{The problematic ending of $F Q$ II}

Hamilton's notes to the beginning of Canto XII of FQII establish the precedents for Guyon's journey: the voyage of Odysseus in the Odyssey; that of Virgil in the Aeneid; the journey of Carlo and Ubaldo to Armidas's enchanted garden in Tasso, and other classical accounts of journeys such as Jason's search for the Golden Fleece (Spenser 270). A comparison of this episode with the Odyssey is particularly apropos as Odysseus, especially in relation to the seductive powers of Circe, is a traditional exemplar of temperance. If we look back at the whole legend of temperance, however, we find that the Aeneid is the predominant epic influence. The weeping and suicidal Amavia, trapped in her own furor and grief, is strongly reminiscent of Dido, and Guyon's inability to comfort her echoes Aeneas' encounter with Dido in the underworld. The burial of Mordant and Amavia has overtones of the burial ceremonies in the Aeneid such as that of Anchises and of problems of setting the souls at rest of those not properly buried, such as that of Palinurus. The encounter of Trompart and Braggadochio parodies the appearance of Venus, dressed as a huntress, to Aeneas on the shores of Carthage. Guyon's retelling of his quest echoes Aeneas' retelling of the fall of Troy to Dido. The descent into the Cave of Mammon has some parallels with Aeneas's descent into the underworld, as we have already seen through the comparison with Landino's allegorical treatment of the Aeneid; the Histories of Briton play a parallel role to the parades of Roman leaders to come presented to Aeneas in Book VI. I have already suggested a parallel between the destruction of the Bower of Bliss and the death of Turnus. And this is not an exhaustive list.

After the battles for Pauline spiritual renewal in Canto XI previously outlined it would be natural to look to the final canto of the work for the ultimate triumph against intemperance. And this may be a mistake. The Platonic ascent to the divine through love and beauty is essentially reserved for the next book of Spenser's allegory, that of the Knight of Chastity. In his final canto of Book II Spenser portrays 
the in malo version of beauty and love, the parodic inverse of the divine, like that of Clement's serpent at the heart of the Egyptian temple. In the Confessions Augustine describes his love of God in terms of what it is not: "[W]hen I love you, what do I love? It is not physical beauty nor temporal glory not the brightness of light dear to earthly eyes, nor the sweet melodies of all kinds of songs, nor the gentle odour of flowers and ointments and perfumes, nor manna or honey, nor limbs welcoming the embrace of the flesh" (183; X.iv [8]). Spenser in the Bower of Bliss is presenting a parallel range of things that love of God is not, with "limbs welcoming the embrace of the flesh" at its heart.

Reading Spenser, as we have been doing at points in this chapter, in the light of Augustine's Confessions, also opens the possibility that the Bower of Bliss is parodic of Augustine's exegesis of the "dry land" of the Genesis creation story as the "living soul" of the community of the faithful of Book XIII of the Confessions. As Aeneas journeys to found a new Troy in Italy, Guyon and his Palmer journey, in this Augustinian sense, to create a new community of the faithful in a land that emerges from the waters. Their mission is a transformative one, to return an enthralled group of men from beastly to human condition. Once temperance has been "formerly grounded, and fast setteled / On firme foundation of true bountyhed" (II.xii.1.4-5), Guyon and his Palmer can set off on an evangelical mission of their own, to fight for virtue. In Christian terms that firm foundation, I have suggested, is the model of Christ, of whom Augustine can say "you yourself are all my good qualities." One way of reading the progress of Guyon and his Palmer at this point is as a completely triumphant one. The Palmer carries with him a "vertuous staffe" (II.xii.86.1), made of the same wood as Caduceus, the rod of Mercury, and so able to assuage fiends in hell, and this suggests the evangelical power of the Word. The Palmer uses this staff to calm the sea, to calm the raging beasts outside the Bower and finally to transform these beasts back into men. Like Charon as grace in the journey through the underworld in Landino's exegesis, the Palmer can recognise an attack of sea monsters as figments of the mind, beginning the identification of the true from the false that will be the focus of the attack on the Bower.

But as well as establishing the bedrock of Christian morality in the model of Christ as head of the church, Spenser also establishes a strong dichotomy in the opening stanza of the last canto to which we should pay careful attention. That faith is a "firme foundation" (II.xii.1.5) does not in itself ensure that our hero proceeds 
from this point without risk. And it is to the nature of the risk that Spenser is alerting us:

And this braue knight, that for that vertue fightes,

Now comes to point of that same perilous sted,

Where Pleasure dwelles in sensuall delights,

Mongst thousand dangers, and ten thousand Magick mights. (II.xii.1.6-9)

Peril is underlined again in the opening of the next stanza, when "Two dayes now in that sea he sayled has, / Ne euer land beheld, ne liuing wight, / Ne ought saue peril, still as he did pas" (II.xii.2.1-3). Augustine's exegesis of the first six days of creation in the final book of the Confessions identifies the "dry land" at times with the "living soul" of the faithful and at times with "affections disciplined by a strong continence." It also at times identifies the "bitter waters" from which the dry land emerges with faithlessness, and the "whirlpools of the abyss" with those who hide their face from God. Guyon and the Palmer emerge safely from the trials of the open sea but it is to the "sacred soile, where all our perills grow [my emphasis]" (II.xii.37.8-9), and we should note that despite the apparent ease with which the Palmer and boatman have negotiated the dangers of travel hence, their risk increases rather than decreases. The "sacred soile" may be accursed, as the notes in the Hamilton edition suggest (276). It is also ground to be redeemed, to become more positively sacred, sacred in bono. The weak defences of the Bower itself will be breached by "wisedomes powre, and temperaunces might" (II.xii.43.6-7) (the intellectual and moral combination of temperance), "[b]y which the mightiest things efforced bin" (II.xii.43.7). The easy defeat of Pleasure's Porter suggests a self-knowledge that can judge true from false in the manner we have seen in Landino's Charon - the self-knowledge of one informed by grace.

But, as I have argued in Chapter Four, once inside the borders of Acrasia's domain, Guyon and the Palmer's circuitous progress towards Acrasia becomes entangled in the description of the harmonies of the Bower, which suggest the act of love-making itself. Guyon's failure to control his own concupiscence as he is attracted to the women bathing in the fountain is less indicative of self-knowledge and the self-control of a truly established temperance. We are invited to see him as aroused in an unknowing adolescent way, as one naturally temperate like the blushing Charmides (as we are in his encounter with Shamefastnesse) and in doing so, to see him as the kind of parvulus or little one previously discussed - one under 
special protection but also facing a particular risk. And if, as I have been suggesting, Guyon's encounters tend to indicate his own incipient tendencies, his response to Excesse, his breaking her offered wine cup, becomes worryingly excessive. That Guyon ultimately breaks down the Bower "with rigour pittilesse" (II.xii.83.2), can be seen in one way as the natural consequence of insight into the false. In this case, Spenser is representing Protestant zeal and the need to clear away the false to build the new. The newly released Verdant again suggests the beginnings of the Pauline spiritual renewal, so important, I have been arguing, for this allegory. He begins the blossoming Spring that will ripen in subsequent books of the allegory into the Pauline fruits of the spirit. But that we do not see any such rebuilding in this temporal moment of the allegory cannot but lead to unease. There are three aspects to this.

The first is the problem of the relationship of temporal reformation in the context of temporal history. The Histories of Briton are witness to the uneasy relationship of divine revelation and the march of human events, at least in terms of human understanding of these events. That the histories are set in the turret of memory underlines the problem. For Augustine in the Confessions, remembering had the neo-Platonic connotations of recalling a past and a divine origin that had been lost. But retrieving this lost past is a slow process, and one that belongs to a long providential plan. In this context, to think that heaven can be easily created on earth by sweeping away the sins of the past and the present carries the risk of presumption. The problem of presumption has shadowed Guyon and the Palmer in this book and presents the second source of unease. The pair proceeded in the early cantos full of confidence that they could apply solutions of temperance to all the situations of conflict they encountered. The consequence was to gradually place Guyon at the mercy of his foes in the centre of the book, so that he required divine rescue. The third source of unease lies with the nature of the final judgements in the canto.

Augustine, towards the end of the Confessions, in an exegesis of the judgement of humans over the birds of the air and the beasts of the field of the Genesis story, describes two different types of judgement. The spiritual person may judge "by approving what is right and disapproving what he finds wrong in the works and behaviour of the faithful in their charitable giving - like the fruitful earth. He judges the 'living soul' in its affections made gentle by chastity, by fasting, by devout reflection on things perceived by the bodily senses. And lastly he is said to exercise judgement on questions where he possesses a power of correction" (294; 
XIII.xxiii (34)). It is this sort of correction we see exercised by the Palmer throughout the Legend of Temperance. But Augustine also precludes another sort of judgement:

Even a person who is spiritual and is renewed in the knowledge of God according to the image of him who created him has to be a doer of the law, not its critic. Nor does he judge which persons are spiritual and which carnal...To us no works have as yet appeared so that we can know them by their fruits. Yet you, Lord, already know them and have made a division. You called them in secret before the firmament was made. The spiritual person does not judge the storm-tossed peoples of this world. How can he judge of those outside when he does not know who will come out of the world into the sweetness of your grace, and who will remain in the permanent bitterness of godlessness? (293; XIII.xxiii (33))

Augustine's view of predestination prefigures the theology of Calvin, but it creates a problem on one level for the ready destruction of the Bower of Bliss. The problem of Guyon's presumptuous willingness to judge others is signalled in the centre of the legend, in his ready condemnation of the greedy Tantalus, just before his own fall. At the end of the legend it is signalled by his condemnation of Gryll, who repines at being turned back from a beast to a man.

Saide Guyon, See the mind of beastly man,

That hath so soone forgot the excellence

Of his creation, when he life began,

That now he chooseth, with vile difference,

To be a beast, and lacke intelligence. (II.xii.87.1-5)

In the source of the Gryllus story, Plutarch uses the wisdom of the animal to point out the folly of the man (in the manner of Erasmus' Praise of Folly). Recent attention to Plutarch's use of irony by Joseph Loewenstein (253) and Raphael Lyne (172-3) warns us not to take Guyon and the Palmer's easy condemnation of Gryll at face value. It is my own view that the easy and mocking condemnation of Gryll by Guyon and the Palmer, their readiness to judge, may be a joke at their own expense.

The end of FQII is not tragic as Hamlet is tragic. But it does present, from a Protestant perspective, a limited, medieval, ascetic and life-denying temperance that needs next to be tempered by the Protestant charity that accommodates married love. This will be the work of Book Three of The Faerie Queene. It is a failure of married love in the story of Mordant and Amavia, both literally and metaphorically as "fornication against God," that needs still to be redressed. In the meantime, what remains is the inherent problem that bringing moral reformation to others will 
inevitably be the task of those whose own hands can never be completely clean. As Spenser portrays an ideal of spiritual harmony and Christian temperance that comes from the model of Christ in Canto XI, at the end of Canto XII he also portrays the difficulties of the implementation of Christian temperance in the real and imperfect world by those for whom the taint of concupiscence is never completely washed away. The problematic relationship between temperance and justice, so significant in Euripides' Hippolytus and Virgil's Aeneid, is not resolved by this book. The apparently virtuous, godly, pius, and temperate do not easily eliminate intemperance in others. 


\section{Chapter Nine: Hamlet and the journey towards temperance}

\section{The "infants of the spring"}

The tragic parameters of Hamlet are signalled early in the play in Laertes' admonition to Ophelia:

The canker galls the infants of the spring

Too oft before their buttons be disclosed,

And in the morn and liquid dew of youth

Contagious blastments are most imminent.

Be wary then, best safety lies in fear (I.3.39-42)

This formulaic piece of rhetoric is both almost humorously portentous and sinister. At the end of the play all its three "infants of the spring," Ophelia, Laertes and Hamlet will be dead - they will have all failed to be sufficiently "wary."

Both FQII and Hamlet are concerned with "little ones," and the risks of "imminent" and "contagious blastments." It is at the point of ultimate consequences that the allegory of $F Q I I$ and the tragedy of Hamlet part company. The victory of Guyon and his Palmer may not be as absolute as it seems - they are, I have suggested, gently mocked for their presumption at the end of $F Q \mathrm{II}$ - but they travel on to fight the daily battles of the mostly naturally continent against incontinence. In its tragic conclusion, Hamlet is closer to Euripides' Hippolytus than to Spenser, to the tragedy of the young man who, disgusted at the incontinence of others, fails to appreciate the intemperance of his own ascetic denial of love and the procreation it brings. The need to approach human desire and procreation with the wariness and "fear" expressed by Laertes is catastrophic for the kingdom of Denmark. Among other things, it results in a failure to renew a dynasty through marriage and the succession of regal offspring. In Euripides' play, Hippolytus' righteous attack on Phaedra brings catastrophic destruction in its wake. Hamlet condemns his mother's concupiscence and rejects Ophelia's love, either from principles of aesthetic denial and disgust or for reasons of strategy, or both. Through strategy he discovers the truth of Claudius's intemperance and his father's murder, and the cause laid on him by the ghost becomes in this sense just. But the justice of the cause does not in itself make revenge the right path to redress the wrong. Hamlet's knowledge unleashes the further catastrophe of death for the entire ruling house and the family of its chief 
counsellor - the costs of his righteous anger are extremely high. And this is the underlying problem of the play, the problem of the end of the Aeneid - how do you respond to intemperance without incurring the costs of intemperance in your own response? In this particular tragedy, Shakespeare is at pains to make it clear that the costs of intemperance are not only political and moral but also spiritual. The metaphysical elements of the play belong to stock treatments of temperance and, I will argue, as they do in Spenser, also allude to Pauline spiritual renewal.

As we have seen in Clement and in Spenser, Shakespeare's intermeshing of the moral and the spiritual reflects a long tradition of blending the classical and the Christian. This tradition underpins and is evoked by some of the formulaic references in the play. Laertes' warning of the risk to the "infants of the spring" seems essentially about moral danger, but Ophelia makes the warning the work of the "ungracious pastor," and about "the thorny path to heaven" (1.3.47-8). The "infants of the spring" risk not only moral and social disgrace but also their immortal souls. The division of thorny ways and primrose paths goes back to Xenophon and Prodicus' story of the choice of Heracles - the same source from which Clement's use of the "pure garment of sophrosyne" ultimately derives, Heracles meeting with two women, one bad and incontinent and one good and temperate (Memorabilia, I.ii.21). Such congruence of original sources is not surprising when temperance is the underlying concern of both FQII and Hamlet. Ophelia is teasing Laertes; both are mocking stock directions to temperance; and Ophelia's speech plays with the theme of hypocrisy on the part of the advice-giver, so central to the play. The ultimate spiritual risks of "contagious blastments" (1.3.42) to tender buds and buttons has also become a topic of the play, part of its fabric of desperate risks accompanying desperate choices.

Part of the pathos of the tragedy of Hamlet can be found in its hints of counterpointing models of temperance, and journeying paths to redemption. The motif of the soul under attack in a medieval castle that is the body, central to $F Q I I$, is also central to Hamlet - it plays with the originally Platonic ideal of the temperate body ruled by the soul and is one of the ways Shakespeare alerts the audience to the theme of temperance in his play, from its opening scene of watchers on the battlements of Elsinore. The motif of the besieged castle of the self is associated from the beginning of Hamlet with overtones of a diseased body politic, and the metaphors are not dissimilar to those in Spenser. Old Hamlet has been unable to protect his body from a poison poured, literally and metaphorically, into the porches 
of his ears and so the "whole ear of Denmark" has been "rankly abused" by false reports of its cause (1.5.36-38). The undermining of the body of the leader clearly undermines the body of the state. This in turn makes returning temperance to the kingdom Hamlet's mission, an equivalent quest to that carried out for Alma, the soul, in Spenser's allegory, when Arthur steps out to fight Maleger.

Hamlet's underlying duty to the body politic, as prince and heir presumptive, is spelt out in Laertes' early speech to Ophelia. Upon Hamlet's choices depend:

The sanity [sic] and health of the whole state,

And therefore must his choice be circumscribed

Unto the voice and yielding of that body

Whereof he is the head. (I.3.21-4)

Editors disagree (Shakespeare 95) whether "sanity" "sanctity" or "safety" is the right word at 1.3.21. A reading of Hamlet in terms of temperance makes the case for "sanity" very strong. It directly implies temperance, health of mind, sophrosyne of the type related to health of body as seen in the Charmides. It also implies the indispensable role of the temperate prince to the state. And the ideal of the temperate prince has a metaphysical dimension.

Cicero, in De Legibus, makes a direct link between the self-knowledge that is knowledge of God, the knowledge of the divine element in man, and the effect of this knowledge on the person's behaviour as a citizen of the state. The cupiditates principum is most dangerous not because of the direct effect of his immoral behaviour, but through the loss of his role as an example of temperance for the state (North 284-5). For Livy, control of the lust for power and libido in the ruler is one of the remedies for sickness in the state (North 288-9). Hamlet's despair at Claudius and Gertrude's behaviour in Act One Scene Two, and Shakespeare's use of the metaphor of the diseased body politic, thus follow a strong tradition of attack on intemperance in Roman rhetoric that goes back to the Greek association of sophrosyne with health of body and mind. The ideal of the exemplary and so temperate prince (in the style of Landino's praise of Lorenzo) underlies Ophelia's despairing speech of Act Three, about everything that Hamlet once was and no longer seems to be. The prince will be "th'observed of all observers" (3.1.148); he will be the model of all righteous behaviour, "[t]he glass of fashion and the mould of form" (3.1.147). What has been lost when Hamlet's "noble mind" (3.1.144) is overthrown is the role of the exemplar essential to the health of the state. Ophelia's 
words describe something more strongly moral than courtly elegance, something more like a mirror of all forms of good behaviour, with temperance implicitly at the calm centre.

\footnotetext{
The courtier's, soldier's, scholar's, eye, tongue, sword, Th'expectancy and rose of the fair state, The glass of fashion and the mould of form, Th'observed of all observers... (3.1.145-8)
}

As such a model, Hamlet has been beloved, to the extent that Claudius fears (using language of the transforming spring strongly reminiscent of $F Q I I)$ those who have seen him as their future king will forgive him all sins. Through their "great love" they will "like the spring that turneth wood to stone, / Convert his guilts to graces" (4.7.20-21). As the ruler of the fortified Castle of Alma represents the temperate soul in FQII, so an ideal of the temperate ruler is presented in Hamlet through such glimpses of the Prince of Denmark, the humanist ruler in waiting, before the murder of his father.

As well as the motif of the fortified castle under attack, Shakespeare also has recourse in the latter stages of the play to the motif of transformative epic journeying, like that of Aeneas, and particularly as seen in the exegesis of a neo-Platonic writer like Landino. The idea that Hamlet must, like Aeneas, struggle against furor is introduced with great efficiency into the play through the speech of the Player (2.2.409). Hamlet listens to and watches the description of the "hellish Pyrrhus" (421) striking down a father at a remove that echoes Aeneas' own role as observer in Virgil's description of the death of Priam. Hamlet is, in other words, implicitly identified with Aeneas, and his eventual journeying, truncated as it is in relation to that of an Aeneas or a Guyon, emerges naturally from such associations. Hamlet's travels will also become associated with a quest for an inner harmony of soul.

\section{"Blest are those whose blood and judgement are so well commedled"}

It is in the centre of the play, as we have seen, that the model of temperance is most directly evoked in Hamlet. Here Shakespeare, like Spenser, draws on patristic connotations of temperance. Hamlet's praise of Horatio, as previously discussed, tends to be seen in Stoic terms. Horatio's poverty places him outside the flattery of the court; he becomes in his detachment a figure of Stoic apatheia. But the phrase "blest are those / Whose blood and judgement are so well commedled / That they are 
not a pipe for Fortune's finger / To sound what stop she please" (3.2.58-61) clearly echoes the Beatitudes as well as Cicero or Seneca. And in the Church Fathers, the Beatitudes are directly conflated with the virtue of temperance. Ambrose, for example, in a funeral oration for his brother Satyrus, equates the "Blessed are the poor" of Luke with the "Blessed are the poor in spirit" of Matthew. He associates both Beatitudes with "Blessed are the pure in heart" (North 367). The relationship is not hard to understand. The poor, having temperantia, despise the world and do not seek its temptations, and so demonstrate purity of heart and soul. Hamlet plays on "cor" as "heart" in his description of wearing the man who is not passion's slave in his "heart's core, ay in my heart of heart" ( 3.2.63), as Hibbard explains in the notes to his edition of Hamlet (251). Hamlet, in other words, is reaching for an ideal of temperance as purity of heart. The promise of the Beatitudes for the "poor in spirit" is the kingdom of God; for the "pure in heart" that they will see God. Other Church Fathers similarly associate temperance and the Beatitudes. Again it is not hard to see why temperance, associated in Plato with knowledge of and assimilation to God, so that the temperate are beloved of God, would be linked in early Christian writing to the Beatitudes. To see Hamlet's praise of Horatio in these terms strengthens the place of temperance as the metaphysical ideal of the play, the ideal against which all the failures of temperance, and Hamlet's journey towards self-knowledge, can be measured.

Horatio's early metaphor of the "dawn in russet mantle clad" (1.1.166) has linked him implicitly both with the Georgic ideal of the peasant farmer so beloved of Virgil (Scodel 80), and the poverty of the humble, often associated with being "poor in spirit". Russet was not only a colour but an adjective describing the homespun cloth of the garment of the peasant or farm labourer, so the dawn in Horatio's image is russet-coated. And the image of the farmer setting about his day's labour conflates a dawn of redemption (already suggested by Marcellus' discussion of the "bird of dawning") and Christ as the good shepherd or husbandman. The description of Horatio in the centre of the play as one who "suffering all...suffers nothing" (3.2.56) continues the overtones of redemptive sacrifice. Such allusions may be resonant with significance or lightly placed in the play, but they cannot be overlooked.

\section{The special providence in the fall of a sparrow}

I have argued that the imagery of the central passage of Guyon's faint and rescue by an angel in FQII can be explained by Augustine's prayer in the Confessions, for the 
rescue by an angel of the fledgling chicken or "little one" who through presumption falls from the nest of faith. In Hamlet, a yearning for a similar divine protection and intervention, an underlying appeal to the agency of grace, comes through imagery whose Biblical provenance (despite the apparent fatalism of the language that surrounds it) is indisputable; Hamlet's assurance is that " $[t]$ here is special providence in the fall of a sparrow" (5.2.192-3). The promise of Matthew 10.29 is that nothing happens without God's knowledge, even to the most humble: "Are not two sparrows sold for a farthing? And one of them shall not fall on the ground without your Father." Like the allusion to the Beatitudes, the reference to the fall of the sparrow points to the Christian virtue of humility, a virtue that Aquinas explicitly associates with temperance in the Summa Theologiae. God knows about the fall of the sparrow precisely because it is so humble. If we see Hamlet as a play about temperance, such reference to Christian humility becomes a logical dimension of the play. That Hamlet's scriptural allusion is carefully placed is made clear by the other central allusion to birdlife in the play to which it must refer, Claudius's grief over his "limed soul."

Guyon's life leaves its "nest", but it is returned by the angel to its "home," in the centre of $F Q I I$. His life is "courd" by the Palmer, like the mother hen of Christ's promise to Jerusalem, with a play on "cor" like that of Shakespeare's "heart's core," in the praise of Horatio's temperance. Shakespeare's Claudius tries to pray for angels to rescue him: "Help, angels! Make assay"(3.3.69-70). But no angel comes to rescue him. His "limed soul" is trapped; "struggling to be free", it is "more engaged" (3.3.68-9). The image of the struggling bird caught in quicklime is a distressing one. It is also Biblical imagery with strong Augustinian overtones. In the Confessions Augustine associates the imagery of rescue from birdlime with the act of conversion itself.

I aspired to honours, money, marriage, and you laughed at me. In those ambitions I suffered the bitterest difficulties; that was by your mercy - so much the greater in that you gave me the less occasion to find sweet pleasure in what was not you. Look into my heart, Lord. In obedience to your will I recall this and confess to you. May my soul now adhere to you. You detached it from the birdlime which held me fast in death [my emphasis]. How unhappy it was! Your scalpel cut to the quick of the wound, so that I should leave all these ambitions and be converted to you, who are above all things and without whom all things are nothing, and that by conversion I should be healed. (97; VI.[8])

While for Augustine, "all these ambitions" - "honours, money and marriage" withheld from him made him less likely to "find sweet pleasure in what was not you," Shakespeare's Claudius has already tasted the joys of the worldly, and because 
of this what he cannot renounce is "[m]y crown, mine own ambition, and my queen" (3.3.55). In the Confessions, Augustine's desire for conversion has strong neoPlatonic overtones, of ascent to and descent away from God. His inability to return to God before his conversion is described in terms of the relationship of truth and falsehood.

You are the truth presiding over all things. But in my greed I was unwilling to lose you, and wanted to have you at the same time as holding on to a lie, in much the same way as no one wants to become such a liar as to lose all awareness of what the truth is. That is why I lost you: you do not condescend to be possessed together with falsehood. Who could be found to reconcile me to you? Was I to beg the help of angels? What prayer should I use? (218; X.xli[66]-xlii[67])

Claudius too needs to find a way to pray, to gain the angelic assistance that comes so freely to Spenser's Guyon. He uses language of rebirth and conversion that is essentially Pauline: "[A]nd heart with strings of steel / Be soft as sinews of the newborn babe" (3.3.70-1). Claudius is, in other words, expressing a desire for spiritual renewal, for the spiritual over the carnal. He wants to become an Augustinian parvulus, a "little one" who can fly free or at the least be rescued as he falls, detached from the birdlime of carnal possessions. But like the Amavia of the opening of FQII, Claudius's heart in the event is irreparably frozen; his words rise up to God but his thoughts do not (3.3.97-8).

Nevertheless, in the centre of the play Claudius's failure to repent sketches the dimensions of a potential path of return to God that Hamlet struggles to find in the rest of the play, and Hamlet's struggle from this point can be seen as a struggle for the spiritual against the carnal. I have previously argued that the Hamlet who observes a Claudius attempting to repent and wishes for the failure of such repentance takes on some of Claudius's characteristics of intemperance from this moment of the play. I also promised to return at this point in the discussion to a counter-movement in the latter part of the play, a movement against the entanglement with the birdlime of intemperance and sin that has so completely enmeshed Claudius. One way of seeing this counter-movement is through the neoPlatonic journey of the soul.

\section{Rescue by pirates as by angels: the new-born babe}

As Claudius's failure to repent lies at the very heart of the play, it is also the hinge on which the play divides; after this failure, Hamlet moves almost immediately to the 
slaying of Polonius. And from this point Hamlet and Ophelia follow a parallel process of unravelling and capture by furor and madness, an unravelling that has violent consequences for both. Hamlet adds to the impulsive slaying of Polonius, the more calculated sending of Rosencrantz and Guildenstern to their executions. Ophelia, driven mad by grief, rejection and deception, allows her emotions to burst forth in an irrational and disconnected monologue and then lets herself be swept away to a watery death. The timing of Ophelia's watery death and Hamlet's miraculous rescue by pirates is not obviously aligned at the narrative level. But at a more subterranean level the two events are clearly linked. Ophelia sings her sad song of death - "he never will come again" (4.5.189) - and asks for God's mercy on all Christian souls at the end of Act Four Scene Five. A sailor enters in Act Four Scene Six, giving Horatio the letter describing his rescue by pirates as "thieves of mercy" (4.6.17). A letter to Claudius follows, describing Hamlet's return to the kingdom "naked" and "alone" (4.7.50-1). The scene ends with the report of Ophelia's drowning. "Too much of water hast thou, poor Ophelia" (4.7.185), pronounces Laertes, "And therefore I forbid my tears."

Hamlet returns to Elsinore with no possessions; he is naked, in the sense of destitute. Connotations of rebirth must also surround this moment of the play, especially when the requirement for redemption has already been established in the play as having "sinews softer than a new-born babe." Hamlet is cast naked on the shore (not unlike Odysseus appearing to Nausicaa) and Ophelia dies by water. The equivalent moment in $F Q I I$ is the suicidal death of Amavia that follows the birth of Ruddymane, the bloodie-handed babe. The death of Amavia, and of Mordant who brings death, at the opening of $F Q \mathrm{II}$, is mirrored and redeemed at its end in the release of Verdant from the clutches of Acrasia, by the hope, in other words, of renewal and new life. Ophelia dies through suicide, but it cannot be insignificant that her watery tomb is garlanded with spring flowers, and that Elsinore has proceeded from the heart-sickness of winter at the opening of the play into a spring thaw. Ophelia's tragic death is surrounded, in other words, by emblems of hope and renewal. In the Aeneid, Aeneas' love for Dido is expendable in relation to the destiny of Rome, and Dido's death is portrayed as a cruel but necessary sacrifice. In Landino's exegesis, Aeneas' journey away from Dido, who represents the desires of the flesh, is associated with the progress of the soul from incontinence back to continence (174-5). Dido's death is, in some sense, a necessary preliminary to the movement from continence to temperance, the forward movement that involves the 
purgative virtues. After Ophelia's death, Hamlet's miraculous rescue and return to Elsinore comes freighted, in other words, with the expectation of some form of spiritual transformation. And this leads naturally to the great memento mori scene of Hamlet, the discussion over the skull of "poor Yorick" (5.1.156).

\section{Temperance and the preparation for death}

In the centre of FQII, in language that echoes both Aeneas' speech to Dido and Christian theology, an angel tells Guyon's Palmer, “dread of death and dolour doe away" (II.viii.7.7). Placing this central Christian message of hope in the centre of the book, Spenser has made it a message of temperance. In Plato's Phaedo, the life of the sophron philosopher is seen as a preparation for death, so that death is not something to be feared. In Calvin, even more strongly, as we have seen, it is the duty of Christians to be prepared for death "as sheep for the slaughter." In the patristic writers we find an explicit comparison between classical and Christian approaches. Ambrose, for example, in the Oration on the Death of Satyrus (previously cited for its discussion of the Beatitudes) argues that the Christian trumps the classical. He begins by portraying Christ as the death of the body and the life of the soul.

We see, then, that this death is gain and life a penalty, so that Paul says: To me to live is Christ and to die is gain. Philippians 1.21. What is Christ but the death of the body, the breath of life? And so let us die with Him, that we may live with Him. Let there then be in us as it were a daily practice and inclination to dying, that by this separation from bodily desires, of which we have spoken, our soul may learn to withdraw itself, and, as it were placed on high, when earthly lusts cannot approach and attach it to themselves, may take upon herself the likeness of death, that she incur not the penalty of death. (II.40)

He also explains why the Christian treatment of the mele thanatou, the classical philosophical preparation for death, surpasses the classical. Paul's preparation for death surpasses (implicitly) that of Socrates.

I die daily [1 Corinthians 15:31] says the Apostle. Better certainly is this saying than theirs who said that meditation of death was true philosophy, for they praised the study, he exercised the practice of death. And they acted for themselves only, but Paul, himself perfect, died not for his own weakness but for ours. (II.35)

As Hamlet moves overtly to the topic of preparation for death, both a condition of tranquil temperate philosophical calm and a condition of spiritual renewal are at issue. In the opening of Act Five Scene One, we are reminded by the gravediggers of Adam, the origins of original sin and the need for Christian 
redemption as they joke about "Adam's profession" (5.1.26). Hamlet, observing or picking up the skull thrown up by the gravedigger, moves from Adam to describe "Cain's jawbone, that did the first murder" (5.1.65-6), and so the inception of murder and revenge into the world. And this leads naturally to the mocking of intemperate politicians and courtiers. As Hamlet and Horatio joke with the grave digger, the previous urgent pace of the play is slackened and time seems to stretch out, as though to allow Hamlet time to come to a deeper metaphysical understanding. Picking up Yorick's skull, Hamlet is first concerned with women and cosmetics (concerns traditionally associated with temperance, as we have seen): "Now get you to my lady's chamber, and tell her, let her paint an inch thick, to this favour she must come" (5.1.163-4). He moves next to ambition, the fate of Alexander who had been the leader of the world, and then, like the opening of the play on the battlements, to the fate of an "[i]mperious Caesar" (5.1.180). We have seen ambition as the chief impediment to Claudius's repentance, and Hamlet, in his joking about bung-holes, is reaching towards the irrelevance of ambition in a metaphysical order: "Alexander died, Alexander was buried, Alexander returneth to dust" (5.1.176-7). Remembering you must return to the earth is, as we have seen, a stock topic of compilations of themes of temperance.

But rather than becoming resigned to the inevitable fate of all rulers, Hamlet's own personal ambition seems to have been sharpened at this point. This preoccupation finally surfaces when he describes Claudius, almost as if in a moment of confession, as someone who has "[p]opped in between th' election and my hopes" (5.2.65). As a result, a tension between personal ambition and the philosophical acceptance of death - that "a man's life is no more than to say 'one'," (5.2.73) dominates the final stages of the play.

\section{Wrestling with death}

Any immediate philosophical calm that results from the discussion over the skulls is completely undone by the furor with which Hamlet responds to the specific occasion of the death of someone he has loved. It is Laertes' hyperbole that infuriates Hamlet, his rhetorical excess that thus smacks of insincerity, an accusation not unlike that made by Claudius and Gertrude about Hamlet at the beginning of the play. Hamlet's concern with Laertes' desire to "outface" (5.1.245) him seems peevish and more to do with apparent status than anything else. And it is his status that he is keen to assert, announcing himself as "Hamlet the Dane" (5.1.224). Temporal ambition, it 
seems, at this point of the play has the immediate upper hand over philosophical calm and the philosophical perspective of readiness for death.

But there are also strong overtones of catharsis in this sequence. Hamlet announces the love that he has rejected in the play: "I loved Ophelia; forty thousand brothers / Could not with all their quantity of love / Make up my sum" (5.1.236-8). If this declaration of love is sincere, its implications are profound. For what is missing in Hamlet, as in FQII, is the redemption of happy married love. Both FQII and Hamlet begin with the distortion of such married love in the form of adultery. As adultery is associated symbolically with distance from God and fornication against God, marriage is associated with Christ's union with his Church. In disrupting the fornication of Verdant with Acrasia at the end of FQII, Guyon and his Palmer are preparing the ground for the celebration of married love in FQIII and FQIV, love that in Spenser is both personal, and represents the spiritual. Hamlet's denial of love has been lifedenying in a manner similar to that of Euripides' Hippolytus. It has seen all lifeaffirming loving as corrupting lust, and, in the rhetoric of the speech directing Ophelia to a nunnery, has carried overtones of the excess of those Church Fathers who, like Origen, placed virginity and self-abnegation before all else. That this denial of love has been life-denying is underlined by Ophelia's physical death. Love as a path to redemption has also been cast aside, unless Hamlet can find a path to such redemption through Ophelia's suicide, which can then take on overtones of sacrifice.

The actual wrestling in the grave (sanctioned by at least $Q 1$ ) has the potential to be cathartic in a range of ways. Laertes represents the freedom Hamlet is denied when at the beginning of the play Claudius allows Laertes' request to return to Paris and not Hamlet's request to return to Wittenberg. Hamlet's own guilt at the death of Polonius must surface at this point, even if it is not acknowledged, and so Hamlet's rage at Laertes amounts to a kind of emotional transference. His own denial of guilt is clear in his question to Laertes: "What is the reason that you use me thus? / I loved you ever" (5.I.256-7). The burial of Ophelia also provides an occasion in which Hamlet's truncated mourning for his father is allowed to surface openly in a new occasion of grief. Hamlet's rage bursts out from a dam of pent-up and repressed feeling.

There are also archetypal and so metaphysical dimensions to this wrestling in the grave. Hamlet has moved from wrestling philosophically with the idea of death over the skull of Yorick to wrestling over a newly dead corpse, and the emblematic effect of this battle on a stage is of wrestling with mortality. In FQII, Arthur's 
struggle with the death-like Maleger leads to Pauline spiritual renewal, the victory of temperance in a metaphysical sense. Like Hamlet's safe though naked return to Denmark, Laertes' and Hamlet's wrestling in the grave could signal some hope for redemption and renewal in the play, especially if an acceptance of death is allied to a replacing of the carnal with the spiritual.

But such a struggle can also be an occasion of great spiritual danger. Landino, in his discussion of temperance as a purgative virtue, states that the attempt to rid oneself of the hold of worldly desires, physical love and worldly ambition is one fraught with the perilous risk of madness and black bile (193). Augustine, in the Confessions, describes attempting to rise neo-Platonically towards union with God and then crashing away, dragged back by the claims of the carnal and worldly; and there are overtones of such an underlying spiritual battle in these final scenes of Hamlet. Augustine describes his early failures in his neo-Platonic attempt to return to God in the Confessions.

The consequence of a distorted will is passion. By servitude to passion, habit is formed, and habit to which there is no resistance becomes necessity. By these links, as it were, connected to one another (hence my term a chain), a harsh bondage held me under restraint. The new will, which was beginning to be within me a will to serve you freely and to enjoy you, God, the only sure source of pleasure, was not yet strong enough to conquer my other will, which had the strength of old habit. So my two wills, one old, the other new, one carnal, the other spiritual, were in conflict with one another, and their discord robbed my soul of all concentration. (140; VIII. Vi (10))

Hamlet, in his speeches in the graveyard, seems to be on the cusp of a metaphysical understanding that would help him put aside temporal battles. And this potential is manifested in the moments of calm of the final Act. But that Hamlet is not moving away from, but embracing the intemperance of Claudius's "limed soul" is also made clear in his justification to Horatio for sending Rosencrantz and Guildenstern to their deaths: "'Tis dangerous when the baser nature comes / Between the pass and fell incensed points / Of mighty opposites" (5.2.60-2).

\section{Is it not to be damned?}

Hamlet's desire to justify his vengeance against Claudius as an act of moral and spiritual reformation (a justification which at this point of the play seems to have replaced all memory of the ghost's injunction) - "is't not perfect conscience / To quit him with this arm? And is't not to be damned / To let this canker of our nature come / In further evil?" (5.2.67-70) - can be seen as arising out of this underlying spiritual 
struggle. Hamlet's motivations, at this stage of the play, have become intractably muddled (and I use this adjective deliberately), between the duty of the Christian to combat their inner intemperance; the importance of the prince as a model of temperance for the state; and an act of political and personal revenge. As previously argued, Hamlet is confusing a metaphorical spiritual death and rebirth with literal death, as though Claudius is literally the old Adam in him which must be killed before he and his kingdom can be redeemed. The movement in the play towards spiritual renewal and redemption is distorted into an ultimate justification for killing Claudius. And so the "buds" of hope and renewal are "blasted with contagion." In the Easter sermon, as we have seen, the Elizabethan congregation was exhorted to kill and offer up the sins of the body, as Christ the Easter lamb had made himself a sacrifice for them. For Hamlet, now self-proclaimed as "the Dane", the temperance of the kingdom will only be achieved through the death of its currently intemperate head, a king who deserves such death because he has "killed my king and whored my mother" (5.2.64), and "popped in between th'election and my hopes" (5.2.65). Not to kill the king is thus conflated by Hamlet with not working to kill the source of personal intemperance and sin. As the presumptive new head of the kingdom Hamlet is also associating the destruction of personal intemperance with the health of the kingdom. It is because of these conflations Hamlet sees the consequence of a failure to kill Claudius as Hamlet's own damnation.

Ambrose (in the Oration on the Death of Satyrus) makes clear the distinction between three distinct kinds of death in theological terms:

[A]ccording to the Scriptures we have been taught that death is threefold.One death is when we die to sin, but live to God. Blessed, then, is that death which, escaping from sin and devoted to God, separates us from what is mortal and consecrates us to Him who is immortal. Another death is the departure from this life, as the patriarch Abraham died, and the patriarch David, and were buried with their fathers; when the soul is set free from the bonds of the body. The third death is that of which it is said: "Leave the dead to bury their own dead" (Matthew 8:22). In that death not only the flesh but also the soul dies, for "the soul that sins, it shall die" (Ezekiel 18: 4). For it dies to the Lord, through the weakness not of nature but of guilt. But this death is not the discharge from life, but a fall through error. (II.36)

What Hamlet seems unable to distinguish, what he has muddled together in his justification for an act of revenge against his uncle, is this difference between spiritual, natural and penal death. The opposite of not being damned is dying to sin and living to God. Hamlet's logic is that living to God ("not to be damned") can be achieved through an act that will bring a natural death to Claudius. Claudius deserves 
this death, according to Hamlet's logic, because he is guilty of the third kind of death, the penal death that is the death of the soul.

In practice in the period, the underlying logic of such justification was used in plotting against monarchs by both sides of the religious divide. Roland Frye cites the example of Pope Gregory XIII's assurance, through Cardinal Como, that those Catholic plotters who attempted to kill Elizabeth would not, by so doing, be guilty of $\sin$ (Frye, 53-4). Not only are the plotters assured of exemption from the usual sanctions for this sin, but they are also to be granted remission of all their sins (Frye 54). On the other hand Calvin, in a discussion of moral behaviour that leads naturally to the issue of the Christian prohibition of revenge in Book II Chapter II of the Institutes, deals with the problem of deception in the application of a general rule to a particular occasion:

That homicide, putting the case in the abstract, is an evil, no man will deny; and yet one who is conspiring the death of his enemy deliberates on it as if the thing was good. The adulterer will condemn adultery in the abstract, and yet flatter himself while privately committing it. The ignorance lies here; that man, when he comes to the particular, forgets the rule which he had laid down in the general case. (Calvin Vol 1, 242; II.ii.23)

Calvin relates this problem to the Aristotelian distinction between incontinence and intemperance.

Where incontinence (akrasia) reigns, he says, that through the passion (pathos), particular knowledge is suppressed: so that the individual sees not in his own misdeed the evil which he sees generally in similar cases; but when the passion is over, repentance immediately succeeds. Intemperance (akolosia), again, is not extinguished or diminished by a sense of sin, but, on the contrary, persists in the evil choice which it has once made. (ibid)

I have previously suggested that one way of seeing the difference between the behaviour of Hamlet and Claudius is in this distinction between incontinence and intemperance - that in the latter part of the play, and particularly in the more calculating sending of Rosencrantz and Guildenstern to their deaths, Hamlet is hardening from a more impulsive incontinence to the intemperance that does not repent of its actions.

\section{Justifying revenge}

When it comes to revenge, Calvin argues that what is at fault is a failure to accept clearly established Christian principles. 
Calvin does allow that avengers of tyrannical wrong can act as the instruments of divine redress. "Herein is the goodness, power, and providence of God wondrously displayed. At one time he raises up manifest avengers from among his own servants, and gives them his command to punish accursed tyranny, and deliver his people from calamity when they are unjustly oppressed; at other times he employs, for this purpose, the fury of men who have other thoughts and other aims" (Vol 1, 674; IV.xx.30).The first act according to the lawful call of God; the latter though they acted with divine sanction "had nought but evil in their thoughts." The possibility that, whether acting from pure or impure motives such avengers could arise should cause princes to fear. But Calvin adds the following warning that should give pause to those who would take the role of avenger upon themselves: "Although the Lord takes vengeance on unbridled domination, let us not therefore suppose that vengeance is committed to us, to whom no command has been given but to obey and suffer" (674-5; IV.xx.31).

When discussing the inadequacy of human reason to direct moral behaviour without grace, Calvin puts this point even more strongly, seeing in the case of action against tyrants both a clear distinction between Christian and classical ethics, and a fundamental failure to obey the injunction against killing in the Second Table of the Decalogue. In this case the reason that does not obey first principles is inadequate.

Every man of understanding deems it most absurd to submit to unjust and tyrannical domination, provided it can by any means be thrown off, and there is but one opinion among men, that it is the part of an abject and servile mind to bear it patiently, the part of an honourable and high-spirited mind to rise against it. Indeed, the revenge of injuries is not regarded by philosophers as a vice. But the Lord condemning this too lofty spirit, prescribes to his people that patience which mankind deem infamous.

In the case of revenge, at least for Calvin, the difference between classical and Christian thought is very clear.

What is problematic in Hamlet is the multiplicity of Hamlet's motivations. If he is sent as the kind of scourge who has "nought but evil" in his thoughts (in Calvin's terms) his own eternal damnation becomes irrelevant. That it is not irrelevant to Hamlet becomes clear when he sees it as "to be damned" not to kill Claudius. He must see himself in that case as a worthy instrument of God's judgement. But in this case the problem remains that Claudius has done nothing that Hamlet himself has not now done himself - that is to kill someone else's father and contrive the execution of other men. The dilemma is sharpened when Hamlet refers to Claudius as "this canker of our nature." In this case the desire for revenge carries 
overtones of the need to restore a Platonic harmony to the Kingdom - to remove a head of state that does not provide a model of temperance to the body politic but instead is the source of its disease. In committing the intemperate act of revenge Hamlet can no longer himself qualify as a viable alternative model of such temperance for Denmark. And that leaves open the question of how this act of removing the canker will cure the kingdom. It is even harder to see how Hamlet will remove the canker of his own intemperate nature, his own "dram of eale" (1.4.18), through an intemperate act of murder.

The unsettled nature of Hamlet's thoughts is seen as he moves from the apparent acceptance of the philosopher's readiness for death ("man's life is not more than to say 'one"'[5.2.74]), to the kind of acknowledgement that might follow such acceptance, the repentance of the incontinent man ("I am very sorry, good Horatio, / That to Laertes I forgot myself'[5.2.75-6]). But this is followed by the justification of intemperate response: "But sure the bravery of his grief did put me / Into a towering passion" (5.2.78-9). And this excuse leaves Hamlet with implicit permission for another act committed in a similar "towering passion."

\section{The readiness is all}

That Hamlet is not entirely convinced of this justification for the potential execution of the King ("is't not perfect conscience / To quit him with this arm? And is't not to be damned / To let this canker of our nature come / In further evil" [5.2.67-70]) is shown by his framing of it as a question. What is "perfect conscience" continues to trouble him just before the duel, with the heartsickness that is "such a kind of gaingiving as would perhaps trouble a woman" (5.2.188-9). Between these two references to the operation of conscience intervenes the arrival of the comic figure Osric, the light relief between statements of great portent. The episode of the mocking of Osric should, however, not perhaps be dismissed too lightly. It stands in Hamlet in something like the role of the episode of Trompart and Braggadochio in FQII. Osric's preening and vacuous self-aggrandisement echo Hamlet's own lack of self-knowledge in a magnified and satirical way.

Cicero, Aquinas and Mancinus all warn against the extreme of being "over nice," particularly in movement, speech and dress. The attack takes a homophobic form, against the risks of "effeminacy." Hamlet's mockery of the "water-fly"

(5.2.82) Osric, the lapwing that "runs away with the shell on his head" (5.2.164), also reminds us of the intrinsic foolishness of young men. The mocking word-play re- 
establishes for a moment in the play the comfortable companionship of Hamlet and Horatio that is most marked in the graveyard scene; it also reveals their own boyishness. They are in a sense little better than "lapwings" themselves. Osric's effete pomposity must also stand as one extreme of courtly behaviour that will be balanced by the extreme of the forthright and martial Fortinbras who enters at the end of the scene. The crucial final sequence of violence is, in other words, bookended by Osric and Fortinbras, Sansloy / Elissa and Huddibras / Perissa figures for Hamlet. That Osric in his self-absorption lacks the gravitas of perspective and selfknowledge is a criticism that can be, less humorously, directed against Hamlet himself.

Spenser plays a similar trick against Guyon, the Knight of Temperance. At the opening of $F Q$ III Guyon is knocked from his horse in an encounter with the Knight of Chastity, and in a comic sequence this loss of face is accounted for by the Palmer as being caused by a disarrangement of Guyon's saddle bags. If we look back from this episode to the grand gesture of the destruction of the Bower of Bliss that concludes FQII, Guyon's apparently heroic behaviour is diminished, and what is revealed are the inadequacies that belong to an impulsive young man lacking a degree of self-knowledge. The temperance of chastity built on the experience of love will be of a different character altogether. That breaking down what is wrong is easier than building up what is right is intimated by the rapid departure from the Bower of Bliss at the end of $F Q I I$. But what can be comic by the end of $F Q I I$ tips inexorably into tragedy in Hamlet. The humorous treatment of Osric points to the inadequacies of Hamlet's own self-aggrandising role as the avenger who will bring reformation to the kingdom by destroying Claudius.

Hamlet describes Osric as hollow, the kind of man who has "only got the tune of the time and outward habit of encounter, a kind of yesty collection, which carries them through and through the most fanned and winnowed opinions; and do but blow them to their trials, the bubbles are out" (5.2.167-170). Hamlet moves from Osric to his own fears - and this transition reveals a further underlying fear that his own justifications for action may also be intrinsically inflated and hollow. FQII describes the "Selfe, whom though we doe not see, / Yet each doth in him selfe it well perceiue to bee" (II.xii.47.8-9). This same self "wondrous things concerning our welfare, / And straunge phantomes doth lett vs oft forsee, / And ofte of secret ill bids vs beware" (II.xii.47.5-7). But unfortunately, tragically, Hamlet finds the inner voice of this "Selfe" that should warn him of "secret ills" at this moment, the feeling of "how 
ill all's here about my heart" (5.2.186), only to reject it. He does so in the context of his recent mockery of Osric, seeing the weakness of the effeminate in his heartsickness, making it "such a kind of gain-giving as would perhaps trouble a woman" (5.2.188-9). Instead he will "defy augury" (5.2.192) adopting a defiant heroic pose more suited to an Achilles, a Turnus, or a Laertes. Being prepared to face death at any moment is one of the characteristics of fortitude, and in choosing fortitude over prudence Hamlet has chosen the extreme represented by Fortinbras.

Hamlet's portrayal of himself as philosophically prepared for death, seeing himself as someone whose soul God will protect as if he were a humble sparrow, is directly dangerous in his case. The borderline between this apparent preparation and the suicidal wish to "dissolve into a dew" of the first act of the play is in one sense very fine. Either Hamlet's judgement is so far removed from reality that he cannot apply the lessons of Claudius's calculation, the lesson learned in particular from the letters he finds on the sleeping bodies of Rosencrantz and Guildenstern, to this imminent encounter with Claudius and Laertes; or he is in a calculated way choosing likely death. And if he is consciously choosing death he is doing so through the language of the preparation for death, both classical and Christian. Gregory of Nyssa, as we have seen, equated "Thy will be done" with temperance (North 351). Hamlet tells Horatio to "let be." For Socrates part of the philosopher's preparation for death is the knowledge that you know nothing; for Hamlet: "Since no man of aught he leaves knows, what is't to leave betimes" (5.2.195-6). Ambrose, among other Church Fathers, also saw at the ultimate extreme, in the purification of the mele thanatou, a preparation for martyrdom. The corollary of seeing oneself damned in not removing Claudius, the "canker" of the kingdom, is to see oneself potentially dying as a martyr to save the kingdom.

But to do so in Hamlet's case is not necessarily a noble or wise act. And it is here that intemperance in the sense opposed to sanity, to "health of mind," must apply. Hamlet's muddle of rationalisations may reflect at this point an authentic movement to a genuine state of inner calm - and it is such a sense that makes us want to believe in a Hamlet who is genuinely "noble," noble because temperate in the metaphysical sense discussed in this chapter. But it may also reflect something closer to a state of Sophoclean delusion. In this case, caught in his own birdlime of justifications, Hamlet displays both the foolishness of an Osric and the recklessness of a Fortinbras. In not acting prudently, he places at risk both his life and his 
immortal soul. His impulses, in other words, are still suicidal. And they are arguably also not just.

In a recent Augustinian treatment of Hamlet, Eric Plumer cites Augustine's

\section{Commentary on Galatians:}

We should never undertake the task of rebuking another's sin without first examining our own conscience by inner questioning and responding unequivocally before God - that we are acting out of love... We should not proudly scorn the sins of others, since in the very act of rebuking them we ourselves sin when we find it easier to respond to the sinner's anger with our own anger than to the sinner's misery with our mercy. (qtd Plumer 80).

The problem of hypocrisy is raised at the beginning of Hamlet, when (in Q2) Horatio describes the "mote" (1.1.112) that troubles the mind's eye. In being unable to see the plank in his own eye, Hamlet is in the end most like Sophocles' Oedipus, trapped by his own lack of self-knowledge. For like Oedipus, what Hamlet lacks knowledge of is his own tendency to irascibility. Those who have themselves committed murder are not in a strong position to deliver judgement on others. But in the end it is the justification - "is't not to be damned / To let this canker of our nature come / In further evil?" (5.2.68-70) - that is expressed in Hamlet's final act of furor: "Here, thou incestuous, murd'rous, damned Dane, / Drink off this potion [my emphasis]" (5.2.304-5). Claudius deserves to die because he is damned.

Hamlet's final act of murder shocks us as Aeneas' slaying of Turnus shocks the reader at the end of the Aeneid. All our sympathies are with Hamlet. If he does not kill Claudius and Claudius survives, the truth of the initial murder of Old Hamlet may not be revealed. Hamlet also acts from love for the mother whom he has just seen poisoned before him, a mother who in the event has not been rescued by the timely intervention of her husband from this fate, and whose love for Hamlet has finally been fully expressed in the "O my dear Hamlet" that acknowledges the justice of his claims to her. We have sympathy with Laertes' pronouncement against Claudius: "He is justly served, / It is a poison tempered by himself" (5.2.306-7). But the tragedy of the play is founded on the basis that this has all come too late. We cannot exempt Hamlet from the corrupting influence of the poison of intemperance that Claudius has "tempered by himself" and delivered to the whole body politic.

The deep problem, the essential "matter of the play" - how to fight the intemperance of others without becoming intemperate oneself - is not resolved by the Aeneid, by Spenser's treatment of temperance, or by Hamlet. Laertes reaches for an exchange of forgiveness with Hamlet, but how far Hamlet reciprocates with his 
own knowledge of his wrong-doing is less clear. The kingdom will be left to the strong arm of Fortinbras, but it is less clear that Fortinbras will be the leader who will model the "form of fashion" of temperance in the manner of the prince Hamlet might have been. Fortitude alone, we have seen, can be a dangerous thing. Horatio would have "flights of angels" (5.2.339) accompany Hamlet, martyr-like, to his death. But the ultimate judgement of the play, like the ending of $F Q$ II, is inevitably inconclusive. If Hamlet is a play about temperance this is part of the point. The frailty of human concupiscence ends only in death. I have argued that part of being temperate, of knowing oneself, is to refrain from making judgements about those things that are not for the frail human to know. 


\section{Works Cited}

Aeschylus. Agamemnon. Libation-Bearers. Eumenides. Fragments. Trans. Herbert Smyth. Cambridge, Mass, and London: Harvard UP, 1926.

Ambrose. On the Death of Satyrus. New Advent Website. 2 Aug 2007. http://www.newadvent.org/fathers/3403.htm. Web. 19 May 2009.

Anderson, Judith H. "Patience and Passion in Shakespeare and Milton." Spenser Studies XXI (2006): 205-220.

Aquinas, St Thomas. Summa Theologiae. Volume 36, Prudence. Trans. Thomas Gilby. London: Eyre and Spottiswoode, 1974.

Aristotle. The Ethics of Aristotle: The Nicomachean Ethics. Trans. J.A.K. Thomson. Harmondsworth: Penguin, 1953.

Articles of Religion. Anglicans on-line website. 4 Jan 2006.

http://anglicansonline.org/basics/thirty-nine_articles.html. Web. 17 May 2009.

Augustine. City of God. Trans Marcus Dods. In St Augustine, The Confessions. The City of God. On Christian Doctrine. Great Books of the Western World, Vol 18. Chicago: Encyclopaedia Britannica, 1952.

---. Confessions. Trans. Henry Chadwick. Oxford and New York: Oxford UP, 1991.

---. De Diversis Quaestionibus. Documenta Catholica Omnia website. 14 June 2007. http://www.documentacatholicaomnia.eu/04z/z_0354-

0430_Augustinus De_Diversis_Quaestionibus_Octoginta_Tribus_LT.doc. html. web. 12 July 2009.

---. De Ordine. Sant'Agostino / Augostinus Hipponensis website. 15 July 2006. http://www.augustinus.it/latino/costumi/index.htm. Web. 12 May 2009.

---. De Moribus Ecclesiae. Trans. Richard Stothert. New Advent website. 17 Mar 2006. http://www.newadvent.org/fathers/1401.htm. Web. 17 May 2009.

Baldwin, T.W. William Shakspere's Small Latine \& Less Greeke (2 vols). Urbana: Illinois UP, 1944.

Barbour, Reid. English Epicures and Stoics: Ancient Legacies in Early Stuart Culture. Amherst: Massachusetts UP, 1998.

Barton, John, and John Muddiman, eds. The Oxford Bible Commentary. Oxford: Oxford UP, 2001.

Battenhouse, Roy, ed. Shakespeare's Christian Dimension: An Anthology of Commentary. Bloomington and Indianapolis: Indiana UP, 1994.

Beauregard, David N. Virtue's Own Feature: Shakespeare and the Virtue Ethics Tradition. Newark: Delaware UP, 1995.

Bell, Millicent. Shakespeare's Tragic Skepticism. New Haven and London: Yale UP, 2002.

Berger, Harry Jr. The Allegorical Temper. Vision and Reality in Book II of Spenser's 'Faerie Queene'. Hamden: Archon Books, 1957.

Bieman, Elizabeth. Plato Baptized. Towards the Interpretation of Spenser's Mimetic Fictions. Toronto: Toronto UP, 1988. 
Black, Lynette. "Prudence in Book II of The Faerie Queene." Spenser Studies XIII (1999): 65-88.

Bouwsma, William J. "The Two Faces of Humanism. Stoicism and Augustinianism in Renaissance Thought." A Usable Past: Essays in European Cultural History. Berkeley: California UP, 1990.

Calvin, John. Commentary upon the Acts of the Apostles. Trans. Christopher Fetherston. Ed Henry Beveridge. Grand Rapids, Michigan: Christian Classics Etheral Library. 17 Sept 2007. http://www.ccel.org/ccel/calvin/calcom37.v.iv.html. Web. 12 May 2009.

---. Institutes of the Christian Religion. Trans. Henry Beveridge. London: James Clarke, 1949.

Carne-Ross, D.S. and Kenneth Haynes, eds. Horace in English. Harmondsworth: Penguin, 1996.

Carscallen, J. “Temperance.” The Spenser Encyclopedia. Toronto: Toronto UP, 1990.

Cicero, Marcus Tullius. De Officiis. Trans. Walter Miller. Cambridge, Mass, and London: Harvard UP, 1913.

Clayton, Thomas, ed. The 'Hamlet' First Published (Q1, 1603): Origins, Form, Intertextualities. Newark: Delaware UP, 1992.

Clement of Alexandria. The Instructor. Eds Alexander Roberts and James Donaldson. Trans. Anon. The anti-Nicene Fathers: Translations of The Writings of the Fathers down to AD 325. Vol II. Fathers of the Second Century. Grand Rapids: Wm B Eerdmans Publishing Company, 1979.

Collinson, Patrick. Elizabethans. London: Hambledon, 2003.

---. The Elizabethan Puritan Movement. London: Jonathan Cape, 1967.

Cullen, Patrick. Infernal Triad: The Flesh, the World and the Devil in Spenser and Milton. Princeton: Princeton UP, 1974.

Cunningham, James. Shakespeare's Tragedies and Modern Critical Theory. Madison: Fairleigh Dickinson UP, 1997.

Davies, Catharine. A Religion of the Word: The defence of the reformation in the reign of Edward VI. Manchester: Manchester UP, 2002.

Davis, Walter R. “Alma, Castle of.” The Spenser Encyclopedia. Toronto: Toronto UP, 1990.

Doerksen, Daniel W. "Medina, Elissa, Perissa." The Spenser Encyclopedia. Toronto: Toronto UP, 1990.

Dollimore, Jonathan. Radical Tragedy: Religion, Ideology, and Power in the Drama of Shakespeare and His Contemporaries. Durham: Duke UP, 1984.

Elyot, Thomas. The Book Named The Governor. London: Dent, 1962.

Escobedo, Andrew. Nationalism and Historical Loss in Renaissance England. Foxe, Dee, Spenser, Milton. Ithaca: Cornell UP, 2004.

Fraunce, Abraham. The Arcadian rhetorike: or The praecepts of rhetorike made plaine by examples Greeke, Latin, English, Italian, French, Spanish, out of Homers Ilias, and Odissea, Virgils Aeglogs,... and Aeneis, Sir Philip Sydnieis 
Arcadia, songs and sonnets...At London: Printed by Thomas Orwin, 1588. EEBO.

Frye, Roland Mushat. The Renaissance 'Hamlet'. Issues and Responses in 1600. Princeton: Princeton UP, 1984.

Gless, Darryl J. Interpretation and Theology in Spenser. Cambridge: Cambridge UP, 1994.

Graves, Michael A.R. Burghley: William Cecil, Lord Burghley. London: Longman, 1998.

Greenblatt, Stephen. Hamlet in Purgatory. Princeton: Princeton UP, 2001.

Guillory, John. “'To Please the Wiser Sort': Violence and Philosophy in Hamlet”. In Carla Mazzio and Douglas Trevor, eds. Historicism, Psychoanalaysis and Early Modern Culture. New York: Routledge, 2000.

Hadfield, Andrew, ed. Literature and Censorship in Renaissance England. Houndmills: Palgrave, 2001.

---. Shakespeare and Republicanism. Cambridge: Cambridge UP, 2005.

Hamilton, A.C. "A Theological Reading of The Faerie Queene, Book II." Journal of English Literary History 25.3 (Sept 1958): 155-162.

Harward, Simon. Encheiridion Morale: in quo Virtutes quatuor (vt vocant) cardinales, ex clarissimis oratoribus et poetis Graecis, Latinis, Italicis, Hispanis Gallicisque gnomologikos describuntur. London: Edm Bollifantus, 1596. In EEBO.

Hassel, R Chris Jr. "The Accent and Gait of Christians: Hamlet's Puritan style". Shakespeare and the Culture of Christianity in Early Modern England. Eds Dennis Taylor and David N. Beauregard. New York: Fordham UP, 2003. 285311.

Healey, Patrick. "Staying cool and irritating your opponent". New York Times, 16 Oct. 2008. Web. 20 Oct 2008.

Helgerson, Richard. Forms of Nationhood: The Elizabethan Writing of England. Chicago: Chicago UP, 1992.

Hibbard, G.R. ed. Hamlet. Oxford: Oxford UP, 1987.

Hoeniger, David F. Medicine and Shakespeare in the English Renaissance. Newark: Delaware UP, 1992.

Hutson, Lorna. Thomas Nashe in Context. Oxford: Clarendon Press, 1989.

James, Susan. Passion and Action: The Emotions in Seventeenth-Century Philosophy. Oxford: Clarendon Press, 1997.

Jones, Norman. The English Reformation: Religion and Cultural Adaptation. Oxford: Blackwell, 2002.

Kaske, Carole. "Augustinian Psychology in The Faerie Queene Book II." University of Hartford Studies in Literature 15:3 (1984): 93-8.

Kraye, Jill. "Moral Philosophy". In Schmitt, Charles B, and Questin Skinner, The Cambridge History of Renaissance Philosophy. Cambridge: Cambridge UP, 1988. 
Landino, Cristoforo. Cristoforo Landino's Allegorization of 'The Aeneid': Books III and IV of the Camaldolese Disputations. Stahel, Thomas Herbert. John Hopkins University PhD dissertation, 1968.

Lee, John. Shakespeare's Hamlet and the Controversies of Self. Oxford: Clarendon Press, 2000.

Lee, Kam-lun Edwin. Augustine, Manichaeism, and the Good. New York: Peter Lang, 1999.

Levy, Eric P. "The Problematic Relation between Reason and Emotion in Hamlet." Renascence 53.2 (Winter 2001): 82-97.

---. "'Things standing thus unknown': The Epistemology of Ignorance in Hamlet." Studies in Philology 97 (Spring 2000): 192-209.

---. "'What should we do?': The Predicament of Practical Reason in Hamlet." Renaissance and Reformation XXIII.4 (1999): 45-62.

Loewenstein, Joseph. “Gryll's Hoggish Mind.” Spenser Studies XXII (2007): 243256.

Logan, George M, and Gordon Teskey, eds. Unfolded Tales: Essays on Renaissance Romance. Ithaca: Cornell UP, 1989.

Lyne, Raphael. "Grille's Moral Dialogue: Spenser and Plutarch.” Spenser Studies XIX (2004): 159-176.

MacIntyre, Alasdair. "Sophrosune: How a Virtue can Become Socially Disruptive." Midwest Studies in Philosophy XIII (1988): 1-11.

McCabe, Richard. The Pillars of Eternity: Time and Providence in The Faerie Queen. Blackrock: Irish Academic Press, 1989.

McEachern, Claire. The Poetics of English Nationhood, 1590-1612. Cambridge: Cambridge UP, 1996.

Mallette, Richard. Spenser and the Discourses of Reformation England. Lincoln: Nebraska UP, 1997.

Maus, Katharine Eisaman. Inwardness and Theater in the English Renaissance. Chicago: Chicago UP, 1995.

Miles, Geofffrey. Shakespeare and the Constant Romans. Oxford: Clarendon Press, 1996.

Miola, Robert S. 1992. Shakespeare and Classical Tragedy: The Influence of Seneca. Oxford: Clarendon Press, 1992.

Neill, Michael. Issues of Death: Mortality and Identity in English Renaissance Tragedy. Oxford: Clarendon Press, 1997.

Nicholson, William, ed. The Remains of Edmund Grindal, DD. Cambridge: Cambridge UP, 1843.

Nohrnberg, James. The Analogy of 'The Faerie Queene'. Princeton: Princeton UP, 1976.

North, Helen. From Myth to Icon. Cornell UP, 1980.

North, Helen. Sophrosyne: Self-Knowledge and Self-Restraint in Greek Literature. Ithaca: Cornell UP, 1966. 
"Of the Declining from God." The First Book of Homilies, 1547. Anglican Library Website. http://www.anglicanlibrary.org/homilies/bk1hom08.htm. Web. 17 May 2009.

"Of the Resurrection for Easter Day." The Second Book of Homilies, 1562. Anglican Library Website. http://www.anglicanlibrary.org/homilies/bk2hom14.htm. Web. 17 May 2009.

Owen, John Michael. "The Angel of the great counsel of God and the Christology of the Scots Confession of 1560". Scottish Journal of Theology, 55.3 (2002): 303-324.

Parker, David R. "The Act of Supremacy and the Corpus Christi Carol." English Language Notes XXX.2 (Dec 1992): 5-9.

Pasnau, Robert. Thomas Aquinas on Human Nature: A Philosophical Study of Summa Theologiae 1 a 75 -89. Cambridge: Cambridge UP, 2002.

Paster, Gail Kern. "Plenary Address". Fourth International Spenser Society Conference, Toronto, May 2006.

Pieper, Josef. Fortitude and Temperance. Trans. Daniel F. Coogan. New York: Pantheon, 1954.

Plato. Charmides, Alcibiades I and II, Hipparchus, The Lovers, Theages, Minos, Epinomis. Trans. W.R.M. Lamb. London: Heinemann, 1927.

---. The Laws. Trans. Trevor J Saunders. Harmondsworth: Penguin, 1970.

---. The Republic. Trans. H.D.P. Lee. Harmondsworth: Penguin, 1955.

Plumer, Eric. "There's a Divinity that Shapes our Ends: An Augustinian Reading of Hamlet." Augustine and Literature. Eds. Robert P Kennedy, Kim Paffenroth and John Doody. Lexington Books, 2005. 63-97.

Potts, Abbie Findlay. Shakespeare and 'The Faerie Queene'. New York: Greenwood Press reprint, 1969.

Prescott, Anne Lake. "Mammon". The Spenser Encyclopedia. Toronto: Toronto UP, 1990.

Quinn, Kenneth, ed. Horace: The Odes. Basingstoke: Macmillan Education, 1980.

Ridley, Jasper. Elizabeth I: The Shrewdness of Virtue. New York: Viking, 1987.

Robinson, Jenefer. "Emotion: Biological Fact or Social Construction?" Thinking About Feeling: Contemporary Philosophers on Emotions. Ed. Robert C. Solomon. Oxford: Oxford UP, 2004. 28-43.

Rust, Jennifer. "Wittenberg and Melancholic Allegory: The Reformation and its Discontents in Hamlet." Shakespeare and the Culture of Christianity in Early Modern England. Eds Dennis Taylor and David N. Beauregard. New York: Fordham UP, 2003. 285-311.

Schmitt, Charles B, and Quentin Skinner, eds. The Cambridge History of Renaissance Philosophy. Cambridge: Cambridge UP, 1988.

Schoenfeldt, Michael C. Bodies and Selves in Early Modern England: Physiology and Inwardness in Spenser, Shakespeare, Herbert, and Milton. Cambridge: Cambridge UP, 1999.

Scodel, Joshua. Excess and the Mean in Early Modern English Literature. Princeton: Princeton UP, 2002. 
Shakespeare, William. Hamlet, Prince of Denmark. Ed. Philip Edwards. Cambridge: Cambridge UP, 2003.

Shuger, Debora Kuller. The Renaissance Bible: Scholarship, Sacrifice, and Subjectivity. Berkeley: California UP, 1994.

Simpson, James. Burning to Read. English Fundamentalism and its Reformation Opponents. Cambridge, Mass: Belknap Press, 2007.

Sinfield, Alan. "Hamlet's Special Providence". Shakespeare Survey 33 (1980): 89-99.

Solomon, Robert C, ed. Thinking about Feeling. Contemporary Philosophers on Emotions. Oxford: Oxford UP, 2004.

---. "Emotions, Thoughts, and Feelings: Emotions as Engagements with the World." In Thinking About Feeling: Contemporary Philosophers on Emotions. Ed. Robert C. Solomon. Oxford: Oxford UP, 2004. 76-88.

Sophocles. Oedipus the King. In The Three Theban Plays. Trans. Robert Fagles. Harmondsworth: Penguin, 1982.

Spenser, Edmund. The Faerie Queene. Ed A.C. Hamilton. London: Longman, 2001.

Stern, Virginia F. Gabriel Harvey: His Life, Marginalia and Library. Oxford: Clarendon Press, 1979.

Stump, Eleonore. Aquinas. London: Routledge, 2003.

Sweetnam, Mark S. "Hamlet and the Reformation of the Eucharist." Literature and Theology 21.1 (March 2007): 11-28.

“Temperance". Oxford English Dictionary Online.

Thirsk, Joan. Economic Policy and Projects: The Development of a Consumer Society in Early Modern England. Oxford: Clarendon Press, 1988.

Tilmouth, Christopher. Passion's Triumph over Reason: A History of the Moral Imagination from Spenser to Rochester. Oxford: Oxford UP, 2007.

Tuckey, T.G. Plato's 'Charmides.' Cambridge: Cambridge UP, 1951.

Turberville, George. A plaine path to perfect vertue, deuised \& found out by Dominik Mancinus, a Latine Poet (1568). Of Temperance. Literature Online.

Walls, Kathryn. "Peace as a Carpenter's Square in Guillaume de Deguileville's 'Pelerinage de Vie Humaine." Of Pavlova, Poetry and Paradigms: Essays in Honour of Harry Orsman. Eds. Laurie Bauer and Christine Franzen. Wellington: Victoria UP, 1993. 261-73.

Waters, D. Douglas. Christian Settings in Shakespeare's Tragedies. Cranbury, NJ: Associated University Presses, 1994.

Watt, Jeffrey R. “Calvin on Suicide.” Church History, 66, 1997: 463-476. Web. 19 May 2009. http://www.questia.com/googleScholar.qst?docId=97924913.

Williams, R.D., ed. The Aeneid of Virgil. Houndmills: St Martin's Press, 1973.

Wittgenstein, Ludwig. Philosophical Investigations. Trans G.E.M. Anscombe. Oxford: Blackwell,1953.

Wofford, Susanne L. "The Faerie Queene, Books I-III". The Cambridge Companion to Spenser, ed Andrew Hadfield. Cambridge, Cambridge UP, 2001.

Wood, Rufus. Metaphor and Belief in 'The Faerie Queene'. Houndmills: Macmillan Press, 1997. 